\title{
SLUDGE BATCH 5 SIMULANT FLOWSHEET STUDIES
}

D. P. Lambert

M. E. Stone

B. R. Pickenheim

D. R. Best

D. C. Koopman

October 2008

Environmental \& Chemical Process Technology Savannah River National Laboratory Aiken, SC 29808 


\section{DISCLAIMER}

This work was prepared under an agreement with and funded by the U.S. Government. Neither the U. S. Government or its employees, nor any of its contractors, subcontractors or their employees, makes any express or implied:

1. warranty or assumes any legal liability for the accuracy, completeness, or for the use or results of such use of any information, product, or process disclosed; or

2. representation that such use or results of such use would not infringe privately owned rights; or

3. endorsement or recommendation of any specifically identified commercial product, process, or service.

Any views and opinions of authors expressed in this work do not necessarily state or reflect those of the United States Government, or its contractors, or subcontractors.

\section{Printed in the United States of America}

Prepared For

U.S. Department of Energy 
Key Words: DWPF, Sludge, SB5

Retention: Permanent

\section{SLUDGE BATCH 5 SIMULANT FLOWSHEET STUDIES}

D. P. Lambert

M. E. Stone

B. R. Pickenheim

D. R. Best

D. C. Koopman

October 2008

Environmental \& Chemical Process Technology

Savannah River National Laboratory

Aiken, SC 29808

Prepared for the U.S. Department of Energy Under 


\section{REVIEWS AND APPROVALS}

\section{AUTHORS:}

D. P. Lambert, Process Technology Programs

Date

M. E. Stone, Process Technology Programs

Date

B. R. Pickenheim, Process Technology Programs

Date

D. C. Koopman, Process Technology Programs

Date

D. R. Best, Process Technology Programs

Date

\section{TECHNICAL REVIEWER:}

J. M. Pareizs, Process Technology Programs

Date

\section{APPROVERS:}

C. C. Herman, Manager, Process Technology Programs

Date

J. C. Griffin, Manager, E\&CPT Research Programs

Date

J. E. Occhipinti, Manager, Waste Solidification Engineering

Date 


\section{EXECUTIVE SUMMARY}

The Defense Waste Processing Facility (DWPF) will transition from Sludge Batch 4 (SB4) processing to Sludge Batch 5 (SB5) processing in early fiscal year 2009. Tests were conducted using non-radioactive simulants of the expected SB5 composition to determine the impact of varying the acid stoichiometry during the Sludge Receipt and Adjustment Tank (SRAT) and Slurry Mix Evaporator (SME) processes. The work was conducted to meet the Technical Task Request (TTR) HLW/DWPF/TTR-2007-0007, Rev. $1^{1}$ and followed the guidelines of a Task Technical and Quality Assurance Plan (TT\&QAP) ${ }^{2}$.

The flowsheet studies are performed to evaluate the potential chemical processing issues, hydrogen generation rates, and process slurry rheological properties as a function of acid stoichiometry. Initial SB5 flowsheet studies were conducted to guide decisions during the sludge batch preparation process. These studies were conducted with the estimated SB5 composition at the time of the study. The composition has changed slightly since these studies were completed due to changes in the washing plan to prepare SB5 and the estimated SB4 heel mass.

Nine DWPF process simulations were completed in 4-L laboratory-scale equipment using both a batch simulant (Tank 51 simulant after washing is complete) and a blend simulant (Tank 40 simulant after Tank 51 transfer is complete). Each simulant had a set of four SRAT and SME simulations at varying acid stoichiometry levels (115\%, 130\%, 145\% and 160\%). One additional run was made using blend simulant at $130 \%$ acid that included additions of the Actinide Removal Process (ARP) waste prior to acid addition and the Modular Caustic Side Solvent Extraction (CSSX) Unit (MCU) waste following SRAT dewatering.

There are several parameters that are noteworthy concerning SB5 sludge:

$>$ This is the first batch DWPF will be processing that contains sludge that has had a significant fraction of aluminum removed through aluminum dissolution.

$>$ The sludge is high in mercury.

$>$ The sludge is high in noble metals

$>$ The sludge is high in $\mathrm{U}$ and $\mathrm{Pu}$ - components that are not added in sludge simulants.

Two SB5 processing issues were noted during testing. First, high hydrogen generation rates were measured during experiments with both the blend and batch simulant at high acid stoichiometry. Also, the reflux time was extended due to the high mercury concentration in both the batch and blend simulant.

Adding ARP will extend processing times in DWPF. The ARP caustic boil took approximately six hours. The boiling time during the experiment with added MCU was 14 hours at the maximum DWPF steam flux rate. This is comparable to the DWPF processing time for dewatering plus reflux without MCU at a $5000 \mathrm{lbs} / \mathrm{hr}$ boil-up rate, but would require significantly more time at boiling at 2000-2500 lbs/hr boil-up rate. The addition of ARP and MCU did not cause any other processing issues, since foaming, rheology and hydrogen generation were less of an issue while processing with ARP/MCU.

$>$ Hydrogen and nitrous oxide generation rates as a function of acid stoichiometry

Hydrogen generation was significantly impacted by the changes in acid stoichiometry from 115\% to $160 \%$ (1.96 to 2.73 moles acid per liter of batch sludge or 1.28 to 1.79 moles acid per liter of blend sludge). For the batch sludge, the hydrogen generation rate was within DWPF limits in the 
SRAT cycle, but exceeded the process limit during the SME cycle at the highest acid stoichiometry (160\%). All of the blend experiments were within the process limits throughout the SRAT and SME cycles. As DWPF will be processing blend sludge, hydrogen likely won't be an issue in DWPF processing but lower acid stoichiometries will minimize hydrogen generation. The nitrous oxide generation peak was relatively insensitive to acid stoichiometry and was relatively low due to the low starting nitrite concentration.

\section{Acid quantities and processing times required for mercury removal}

Mercury was added to the sludge simulant at the start of the SRAT cycle as mercuric oxide at approximately $2.5 \mathrm{wt} \%$ (solids basis) based on the expected composition of the SB5 batch and blend. Mercury was not added to the ARP simulant. Because of the high mercury concentration, the time at boiling was increased from 12 hours to 18 hours to allow sufficient time to strip mercury from the SRAT. Boiling flux was maintained at a scaled rate of $5,000 \mathrm{lb} / \mathrm{hr}$ so a total of $90,000 \mathrm{lb}$ of steam flow in DWPF will be needed to remove $120 \mathrm{lb}$ of mercury. Acid quantities from $115 \%$ to $160 \%$ resulted in satisfactory mercury removal with 18 hours of boiling time (including dewater and reflux time), with the exception of the two lowest acid stoichiometry runs with the blend simulant. ARP/MCU processing did not impact mercury reduction and removal. If DWPF experiences problems stripping mercury, increasing the acid stoichiometry is likely to improve mercury removal. Simulant testing does not simulate the DWPF heel so starting mercury concentrations will be lower in DWPF and shorter steam stripping times should be achievable.

\section{Acid quantities and processing times required for nitrite destruction}

Acid quantities from $115 \%$ to $160 \%$ resulted in satisfactory nitrite destruction with 18 hours of boiling. In all runs, the amount of nitrite present in the SRAT product was less than $100 \mathrm{mg} / \mathrm{kg}$, well below the $1,000 \mathrm{mg} / \mathrm{kg}$ target. The longer boiling time and low starting nitrite concentration both helped to reduce the nitrite by the end of the SRAT cycle.

> Impact of SB5 composition (in particular, manganese, nickel, mercury, and aluminum) on DWPF processing (i.e. acid addition strategy, foaming, hydrogen generation, REDOX control, rheology, etc.)

Acid quantities from $130 \%$ to $160 \%$ resulted in satisfactory process performance with no significant issues noted. Foaming was noted during formic acid addition, but the addition of antifoam equal to the amount added at DWPF was sufficient to control foaming.

Except for the $115 \%$ run, all SRAT products were outside the design bases for yield stress and consistency with the 130\%, 145\% and 160\% runs being below the process limit. The process limits for SME product yield stress were met for the $130 \%$ acid run at $45 \%$ solids, but the $115 \%$ acid run was above process limits and the 145\% and 160\% runs were slightly below process limits. It should be noted that the yield stress and consistency trends seen in rheological properties of the simulants are expected to be similar for the DWPF process slurries, but the absolute values for the simulants are not expected to be prototypical in yield stress or consistency. Adjustment in the solids concentration targets and/or acid stoichiometry should be made if processing problems due to viscous process slurries are noted in DWPF.

The $\mathrm{pH}$ of the condensate generated for all nine SRAT cycles was acidic, but the $115 \%$ acid runs resulted in condensate that was basic by the end of the SRAT cycle and throughout the SME cycle with a pH of approximately 9. All condensates from all other runs had a pH of less than 5. 
The following preliminary recommendations apply for DWPF SB5 processing:

$>$ An acid stoichiometry of $130 \%$ is recommended for initial SB5 processing with a corresponding acid window of $115 \%$ to $160 \%$. The SB5 blend simulant used during the testing had a stoichiometric acid requirement of $1.12 \mathrm{~mol} / \mathrm{L}$, giving an acid addition of $1.45 \mathrm{~mol} / \mathrm{L}$ at $130 \%$ acid.

No changes to the antifoam addition strategy, acid addition rate, or SME solids targets are recommended based on simulant testing.

$>$ The SRAT time at boiling (dewater plus reflux) of 18 hours is recommended based on simulant testing

The recommendation for acid addition during the Shielded Cells processing studies was documented in an internal memorandum. Final recommendations to DWPF on SB5 processing will be made after the SC-7 Shielded Cells testing and will be based on the results of this study and the Shielded Cells tests. 


\section{TABLE OF CONTENTS}

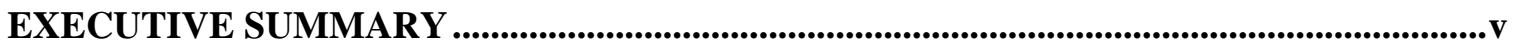

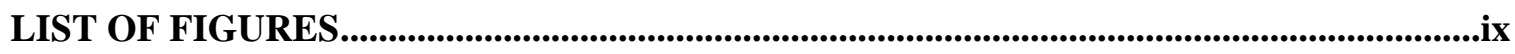

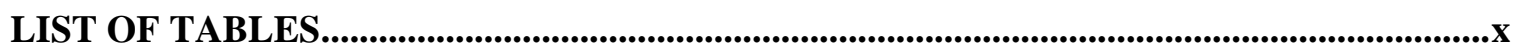

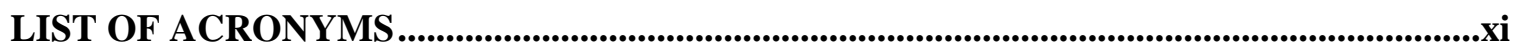

1.0 Introduction and Background.......................................................................................................1

2.0 Approach ...........................................................................................................................................................2

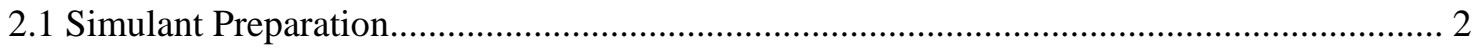

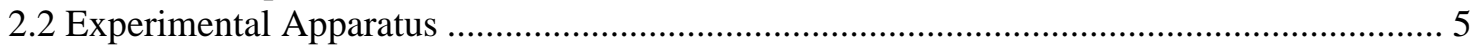

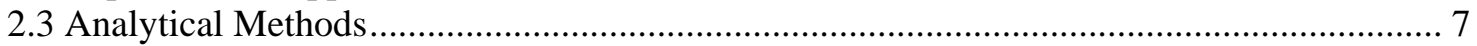

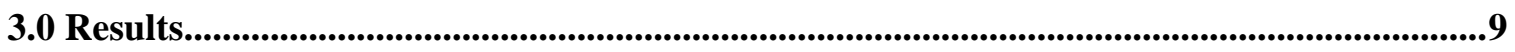

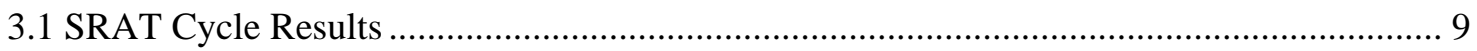

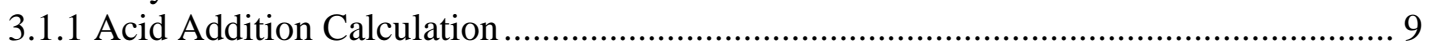

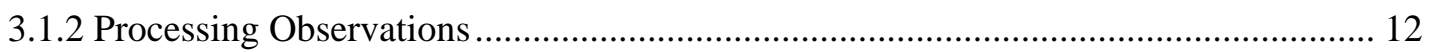

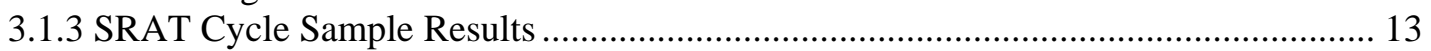

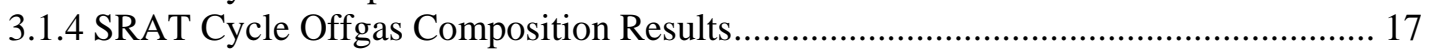

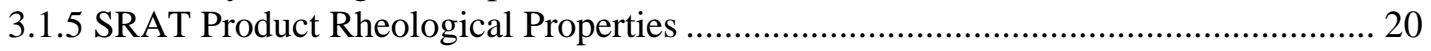

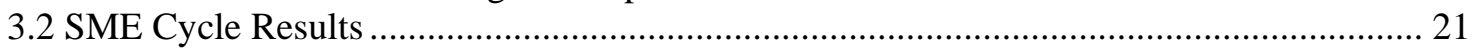

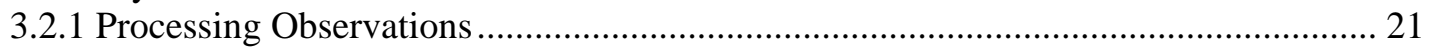

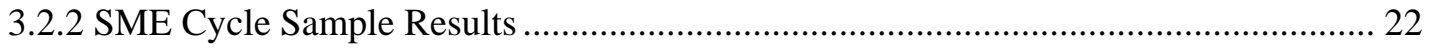

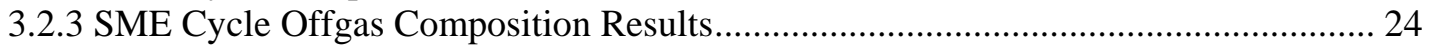

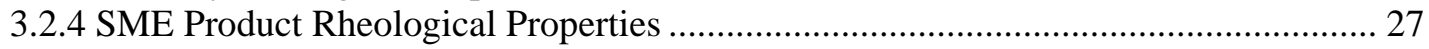

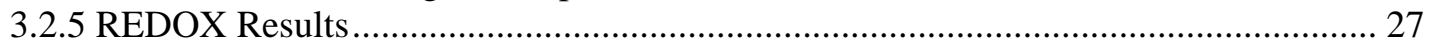

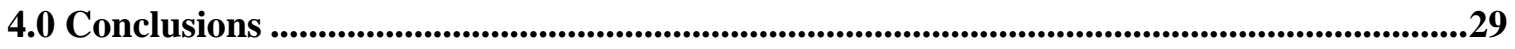

5.0 Recommendations ...........................................................................................................................31

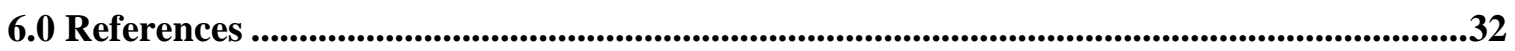

7.0 Acknowledgements .......................................................................................................................33

Appendix A. Sample and Run Results: Tabulated Presentations...............................................34

Appendix B. Sample/Run Results: Graphical Presentations......................................................59

Appendix C. Offgas Composition Data .............................................................................................64

Appendix D. Rheological Results Charts and Flow Curves ......................................................72 


\section{LIST OF FIGURES}

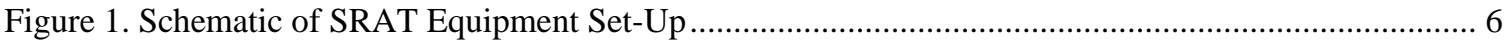

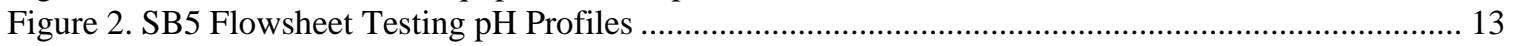

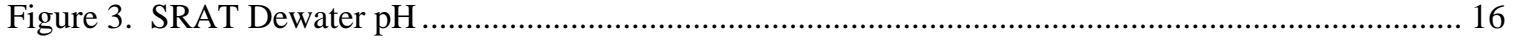

Figure 4. SRAT Cycle Hydrogen Peaks .............................................................................................. 17

Figure 5c. SRAT Cycle Hydrogen Evolution from Tests with Blend Sludge SB5-C .................................... 18

Figure 5d. SRAT Cycle Hydrogen Evolution from Tests with Batch Sludge SB5-D ................................. 19

Figure 6c. SME pH Profile from Tests with Blend Sludge SB5-C............................................................... 21

Figure 6d. SME pH Profile from Tests with Batch Sludge SB5-D ........................................................... 22

Figure 7. SME Dewater $\mathrm{pH}$.............................................................................................................. 24

Figure 8. Typical Offgas Profile 130\% Acid Stoichiometry, Blend Simulant............................................. 25

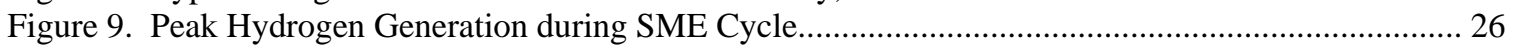

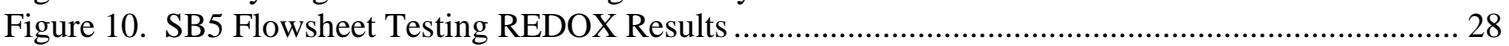

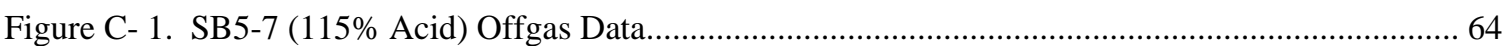

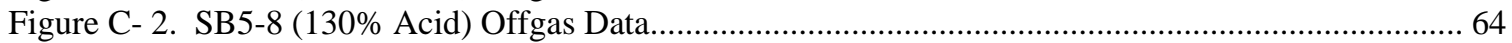

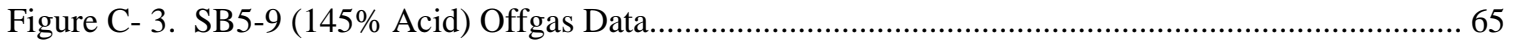

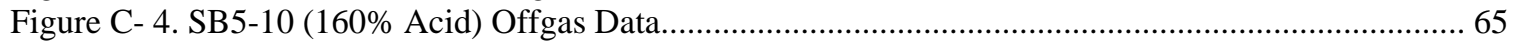

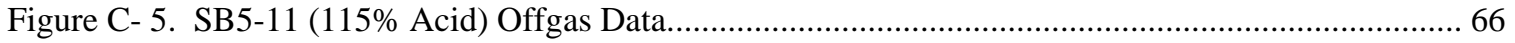

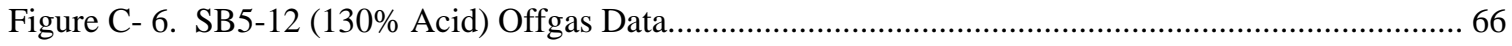

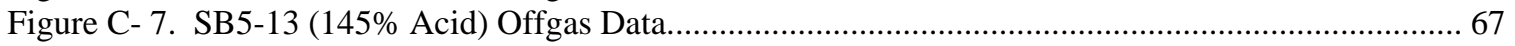

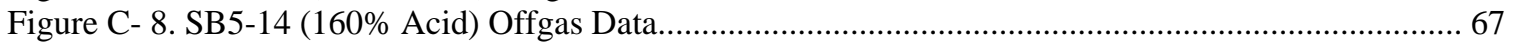

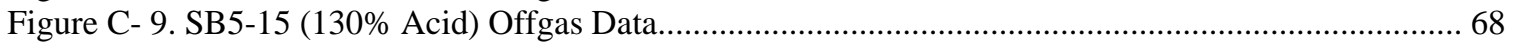

Figure C- 10. Helium Profiles ................................................................................................................ 68

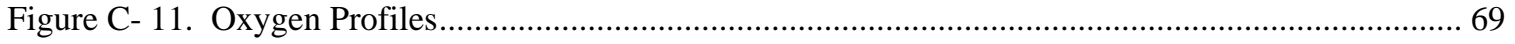

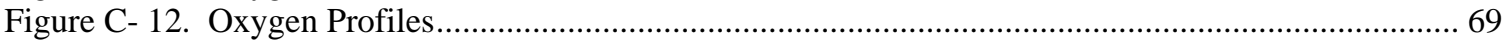

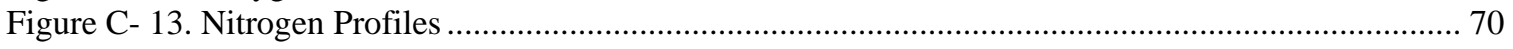

Figure C- 14. Carbon Dioxide Profiles................................................................................................... 70

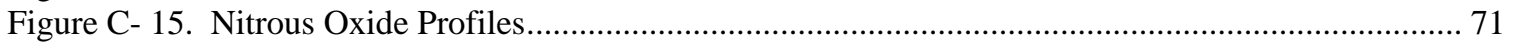

Figure D- 1. SB5-7 (1150\% Acid) SRAT Product Flow Curves................................................................. 72

Figure D- 2. SB5-8 (130\% Acid) SRAT Product Flow Curves................................................................... 72

Figure D- 3. SB5-9 (145\% Acid) SRAT Product Flow Curves...................................................................... 73

Figure D- 4. SB5-10 (160\% Acid) SRAT Product Flow Curves.................................................................... 73

Figure D- 5. SB5-7 (115\% Acid) SME Product Flow Curves..................................................................... 74

Figure D- 6. SB5-8 (130\% Acid) SME Product Flow Curves..................................................................... 74

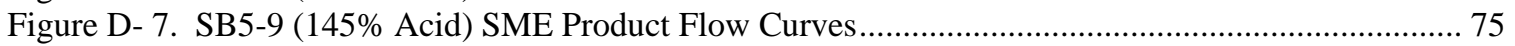

Figure D- 8. SB5-10 (160\% Acid) SME Product Flow Curves...................................................................... 75 


\section{LIST OF TABLES}

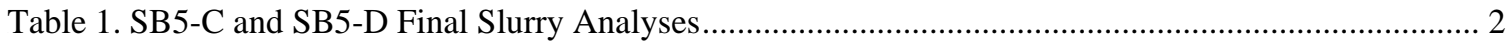

Table 2. Simulant Composition for SB5 Flowsheet Testing ........................................................................ 4

Table 3. Trim Chemical Additions, wt \% on Total Solids Basis ............................................................. 5

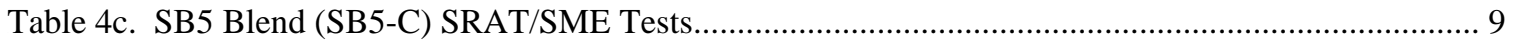

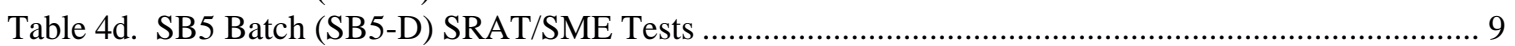

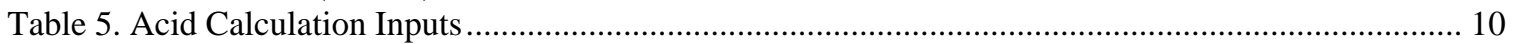

Table 6. SRAT Cycle Processing Parameters and Assumptions ................................................................... 11

Table 7. SME Processing Parameters and Assumptions ............................................................................... 11

Table 8c. Selected Process Values for Testing with Blend Sludge SB5-C................................................. 12

Table 8d. Selected Process Values for Testing with Batch Sludge SB5-D ............................................... 12

Table 9c. SRAT Product Anion Concentration from Tests with Blend Sludge SB5-C, mg/kg................... 14

Table 9d. SRAT Product Anion Concentration from Tests with Batch Sludge SB5-D, mg/kg .................. 14

Table 10c. SRAT Anion Conversions from Tests with Blend Sludge SB5-C, mg/kg.................................. 14

Table 10d. SRAT Product Anion Conversions from Tests with Batch Sludge SB5-D, mg/kg .................... 15

Table 11c. SRAT Product Mercury Results from Tests with Blend Sludge SB5-C ..................................... 15

Table 11d. SRAT Product Mercury Results from Tests with Batch Sludge SB5-D...................................... 15

Table 12. SRAT Cycle Hydrogen Peak Generation Rate ........................................................................... 18

Table 13c. SRAT Cycle Nitrous Oxide and Carbon Dioxide Peak Generation Rates from Tests with Blend Sludge SB5-C....

Table 13d. SRAT Cycle Nitrous Oxide and Carbon Dioxide Peak Generation Rates from Tests with Batch

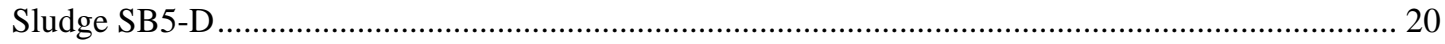

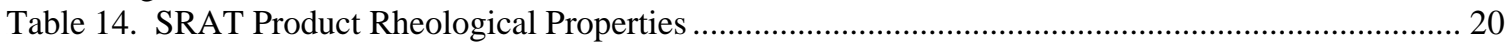

Table 15c. SME Product Results from Tests with Blend Sludge SB5-C..................................................... 22

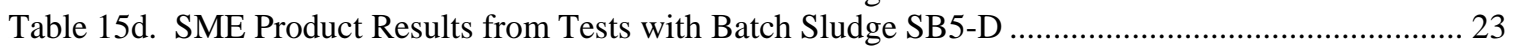

Table 16c. SME Product Anion Conversions from Tests with Blend Sludge SB5-C ................................. 23

Table 16d. SME Product Anion Conversions from Tests with Batch Sludge SB5-D ................................... 23

Table 17. SME Cycle Hydrogen Peak Generation Rate ............................................................................. 26

Table 18c. SME Cycle Nitrous Oxide and Carbon Dioxide Peak Generation Rates from Tests with Blend Sludge SB5-C

Table 18d. SME Cycle Nitrous Oxide and Carbon Dioxide Peak Generation Rates from Tests with Batch

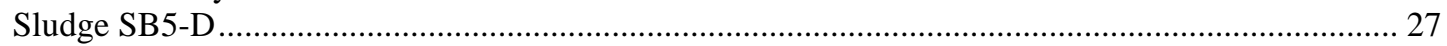

Table 19. SME Product Rheological Properties from Tests with Batch Sludge SB5-D ................................ 27

Table 20. SME Product REDOX from Blend Runs (SB5-11 to SB5-14) ................................................... 27

Table 21c. Offgas Peak Summary Blend................................................................................................ 29

Table 21d. Offgas Peak Summary Batch................................................................................................ 29

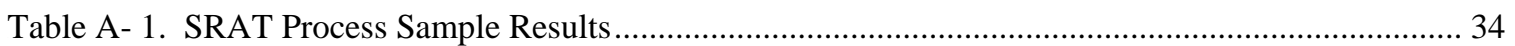

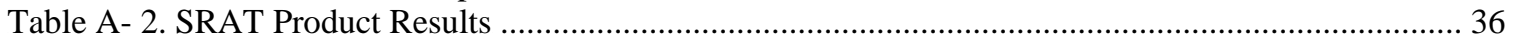

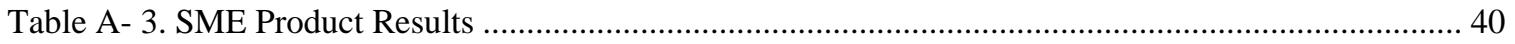

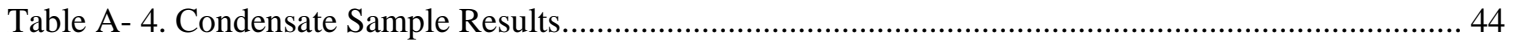

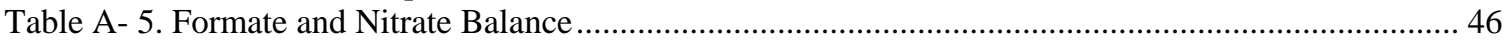

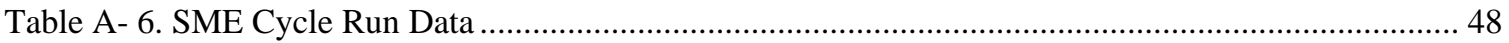

Table A- 7. Mercury Results: SRAT and SME Products .......................................................................... 58 


\section{LIST OF ACRONYMS}

$\begin{array}{ll}\text { ACTL } & \text { Aiken County Technologies Laboratory } \\ \text { AD } & \text { Analytical Development } \\ \text { ARP } & \text { Actinide Removal Process } \\ \text { ASP } & \text { Analytical Study Plan } \\ \text { CPC } & \text { Chemical Process Cell } \\ \text { CS } & \text { Calcine Solids } \\ \text { CSSX } & \text { Caustic Side Solvent Extraction } \\ \text { DWPF } & \text { Defense Waste Processing Facility } \\ \text { FAVC } & \text { Formic Acid Vent Condenser } \\ \text { GC } & \text { Gas Chromatograph } \\ \text { HLW } & \text { High Level Waste } \\ \text { IC } & \text { Ion Chromatography } \\ \text { ICP-AES } & \text { Inductively Coupled Plasma - Atomic Emission Spectroscopy } \\ \text { IS } & \text { Insoluble Solids } \\ \text { MCU } & \text { Modular CSSX Unit } \\ \text { MST } & \text { Mono Sodium Titanate } \\ \text { MWWT } & \text { Mercury Water Wash Tank } \\ \text { PSAL } & \text { Process Science Analytical Laboratory } \\ \text { QA } & \text { Quality Assurance } \\ \text { REDOX } & \text { REDuction / OXidation potential } \\ \text { SB3 } & \text { Sludge Batch 3 } \\ \text { SB4 } & \text { Sludge Batch 4 } \\ \text { SB5 } & \text { Sludge Batch 5 } \\ \text { SME } & \text { Slurry Mix Evaporator } \\ \text { SMECT } & \text { Slurry Mix Evaporator Condensate Tank } \\ \text { SRAT } & \text { Sludge Receipt and Adjustment Tank } \\ \text { SS } & \text { Soluble Solids } \\ \text { SVOA } & \text { Semi Volatile Organic Analysis } \\ \text { TIC } & \text { Total Inorganic Carbon } \\ \text { TS } & \text { Total Solids } \\ \text { TT\&QAP } & \text { Task Technical and Quality Assurance Plan } \\ \text { TTR } & \text { Technical Task Request } \\ & \end{array}$




\subsection{Introduction and Background}

The Defense Waste Processing Facility (DWPF) will transition from Sludge Batch 4 (SB4) processing to Sludge Batch 5 (SB5) processing in early fiscal year 2009. Tests were conducted using non-radioactive simulants of the expected SB5 composition to determine the impact of varying the acid stoichiometry during the Sludge Receipt and Adjustment Tank (SRAT) and Slurry Mix Evaporator (SME) processes. The work was conducted to meet the Technical Task Request (TTR) HLW/DWPF/TTR-2007-0008 ${ }^{1}$ and followed the guidelines of a Task Technical and Quality Assurance Plan (TT\&QAP) ${ }^{2}$.

The flowsheet studies are performed to evaluate the potential chemical processing issues, hydrogen generation rates, and process slurry rheological properties as a function of acid stoichiometry. Initial SB5 flowsheet studies were conducted to guide decisions during the sludge batch preparation process ${ }^{3,4}$. These studies were conducted with the estimated SB5 composition at the time of the study. The composition has changed slightly since these studies were completed due to changes in the washing strategy to prepare SB5 and the estimated SB4 heel mass.

The following TTR requirements were addressed in this testing to validate the existing sludgeonly flowsheet and establish a coupled operations (sludge, Actinide Removal Process (ARP) sludge/Monosodium Titanate and/or Modular Caustic Side Solvent Extraction (CSSX) Unit (MCU) strip effluent) flowsheet for use with SB5. Simulated sludge, ARP sludge/MST, and/or MCU strip effluent will be used to conduct these studies. The TTR requested that the evaluation include calculations, paper studies and/or scoping tests in order to determine the following:

1. "The Hydrogen $\left(\mathrm{H}_{2}\right)$ and Nitrous Oxide $\left(\mathrm{N}_{2} \mathrm{O}\right)$ generation rates for SB5 simulant with varying quantities of acid and noble metals."

3. "The acid quantities and processing times required for mercury removal, nitrite destruction, REDOX control and possible rheology adjustments in the Sludge Receipt and Adjustment Tank (SRAT) for sludge only and coupled operations processing."

5. "The impact of SB5 levels of constituents such as oxalate, titanium, manganese, nickel, mercury, aluminum, cerium and uranium on DWPF processing (i.e. sampling, acid addition strategy, hydrogen generation, REDOX, rheology, etc.)."

6. "High and nominal acid level and bounding noble metal concentration SRAT/SME cycles will be required to complete a parametric study of this flowsheet. The flowsheet will be validated by the completion of a nominal SRAT/SME cycle in SRNL's Shielded Cells (separate TTR) with radioactive sludge slurry samples to be obtained from $\mathrm{H}$ - and F- Tank Farms." "In the simulant flowsheet runs, any observations of foaming, air entrainment, and/or loss of heat transfer capabilities in the SRAT/SME or any indication of excessive offgas deposits leading to pluggage will be noted and evaluated as appropriate. Flow curves (shear stress vs. shear rate) and Bingham plastic rheology data (yield stress and plastic viscosity) for the SRAT and SME material will also be provided. If warranted, the effects of temperature and weight percent solids on rheological properties of process slurries will also be determined." 


\subsection{Approach}

Nine SRAT/SME runs were completed during this study using acid stoichiometries of $115 \%$, $130 \%, 145 \%$, and $160 \%$ with both the Tank 51 batch simulant (SB5-7,8,9 and 10) and the Tank 40 blend simulant (SB5-11,12, 13, and 14). A ninth run was made at $130 \%$ acid stoichiometry with blend simulant that included ARP and MCU additions (SB5-15). These runs were completed and samples analyzed using the practices and procedures typical for Chemical Process Cell (CPC) simulations at the Aiken County Technology Laboratory (ACTL), as described below.

\subsection{Simulant Preparation}

Two simulant batches were prepared, one simulating the Tank 51 composition of batch simulant (SB5-D) and the other simulating Tank 40 or blend simulant (SB5-C). The SB5 batch simulant used targets specified by David Larsen's e-mail ${ }^{5}$. Since the cations in both the batch and blend simulants were very similar, the same cation basis was used to prepare both simulants. The blend simulant target anion composition was specified by Alex Choi ${ }^{6}$. Compositions of the simulants are shown in Table 1.

Table 1. SB5-C and SB5-D Final Slurry Analyses

\begin{tabular}{|c|c|c||c|c||}
\hline Analysis & SB5-C Target & SB5-C Actual & SB5-D Target & SB5-D Actual \\
\hline \hline Total Solids, wt \% & 12.47 & 12.5 & 14.03 & 14.58 \\
\hline Insoluble Solids, wt \% & 8.79 & 7.85 & 8.09 & 8.04 \\
\hline Nitrate, $\mathrm{mg} / \mathrm{kg}$ & 4,533 & 3,940 & 6,881 & 7,114 \\
\hline Nitrite, $\mathrm{mg} / \mathrm{kg}$ & 7,189 & 6,175 & 9,961 & 10,450 \\
\hline TIC, $\mathrm{mg} / \mathrm{kg}$ & 1,633 & 1,338 & 2,000 & 2,485 \\
\hline Fe, wt \% of total dried solids & 21.09 & 21.45 & 20.92 & 20.90 \\
\hline $\mathrm{Al}, \mathrm{wt} \%$ of total dried solids & 11.76 & 12.55 & 10.98 & 11.90 \\
\hline Mn, wt \% of total dried solids & 4.88 & 5.05 & 4.90 & 4.73 \\
\hline $\mathrm{Na}, \mathrm{wt} \%$ of total dried solids & 16.58 & 17.45 & 18.21 & 22.5 \\
\hline \hline
\end{tabular}

The preparation of a simulant for Sludge Batch 5 involved six steps: precipitation of manganese (IV) oxide, caustic precipitation of a metal nitrate solution, addition of sodium carbonate, washing of the precipitated solids, addition of minor insoluble species, and addition of soluble species. The precipitation of metal nitrates to form insoluble oxides and hydroxides was conducted in a Continuous Stirred Tank Reactor (CSTR) and involved generation of a metal nitrate solution followed by precipitation of the metal through the addition of sodium hydroxide. Following the addition of sodium carbonate, the material was washed then soluble/insoluble species were added. Procedure L29 ITS-00124, "SRS HLW Sludge Simulant Preparation (U)" was utilized to perform the tests.

\section{$\underline{\text { Simulant Preparation }}$}

The simulants were prepared intermittently over a two month-long period using facilities at both ACTL and in 735-11A. The $\mathrm{MnO}_{2}$ precipitation, the precipitation in the CSTR and the precipitation of the insoluble carbonate species were each completed in one day. The washing 
and concentration of the precipitate took approximately three weeks, while the final insoluble and soluble species were added in one day.

The simulant preparation was completed in six steps as described below.

Phase I: Manganese Dioxide $\left(\mathbf{M n O}_{2}\right)$ Preparation: Six batches of manganese dioxide were prepared at ACTL by feeding potassium permanganate at $35^{\circ} \mathrm{C}$ at 17.5 $\mathrm{mL} / \mathrm{min}$ to a Manganese nitrate solution at $35^{\circ} \mathrm{C}$.

Phase II: Metal Nitrate Solution Precipitation in CSTR: The metal oxides were coprecipitated in the CSTR setup in 735-11A Lab 123. The $50 \mathrm{wt} \% \mathrm{NaOH}$ solution was fed at $11.5 \mathrm{~mL} / \mathrm{min}$ and the combined $\mathrm{MnO}_{2}$ and Metal Nitrate Solutions were fed to the CSTR at $89.0 \mathrm{~mL} / \mathrm{min}$ to produce a precipitate at a $\mathrm{pH}$ of $\sim 9.5$.

Phase III: Precipitation of Insoluble Carbonate Species: Sodium Carbonate was added to precipitate insoluble carbonate species.

Phase IV: Washing and Concentration of Slurry: The slurry was batch washed in drums. After washing was completed, the slurry was concentrated to the final insoluble solids target in ACTL using paddle filters.

Phase V: Add the final insoluble compounds to the concentrated washed slurry: The remaining insoluble species that might have been removed during washing were added to the washed and concentrated slurry.

Phase VI: Add the final soluble compounds to the concentrated washed slurry: The remaining soluble species that would have been removed during washing were added to the washed and concentrated slurry.

The final slurry was sampled and analyzed at ACTL, the Process Science Analytical Laboratory (PSAL), and by Analytical Development (AD). The results of these analysesare summarized in Table 2. As can be seen, the results agreed well with the planned targets.

The SB5 simulants were very thin rheologically, especially because of the low insoluble solids targets. No measurement of the slurry rheology was completed. 
SRNS-STI-2008-00024

Revision 0

Table 2. Simulant Composition for SB5 Flowsheet Testing

\begin{tabular}{|c|c|c|c|c|c|}
\hline Analyses & $\begin{array}{l}\text { SB5-C } \\
\text { Blend }\end{array}$ & $\begin{array}{l}\text { SB5-D } \\
\text { Batch }\end{array}$ & Analyses & $\begin{array}{l}\text { SB5-C } \\
\text { Blend }\end{array}$ & $\begin{array}{l}\text { SB5-D } \\
\text { Batch }\end{array}$ \\
\hline Elemental & \multicolumn{2}{|c|}{ Wt\% calcined solids } & Solids Data & \multicolumn{2}{|c|}{ Wt \% } \\
\hline $\mathrm{Al}$ & 12.5 & 11.9 & Total & 12.47 & 14.58 \\
\hline $\mathrm{Ba}$ & 0.013 & 0.011 & Insoluble & 7.85 & 8.04 \\
\hline $\mathrm{Ca}$ & 2.11 & 2.31 & Soluble & 4.62 & 6.54 \\
\hline $\mathrm{Cr}$ & .017 & 0.026 & Calcined & 9.51 & 11.09 \\
\hline $\mathrm{Cu}$ & 0.020 & 0.013 & Anions & \multicolumn{2}{|c|}{$\mathrm{mg} / \mathrm{kg}$} \\
\hline $\mathrm{Fe}$ & 21.5 & 20.9 & Chloride & $<100$ & $<100$ \\
\hline $\mathrm{K}$ & 0.157 & 0.074 & Nitrite & 6,175 & 10,450 \\
\hline $\mathrm{Mg}$ & 0.890 & 0.841 & Nitrate & 3,940 & 7,114 \\
\hline $\mathrm{Mn}$ & 5.05 & 4.73 & Formate & $<100$ & $<100$ \\
\hline $\mathrm{Na}$ & 17.5 & 22.5 & Sulfate & 405 & 526 \\
\hline $\mathrm{Ni}$ & 2.63 & 2.44 & Oxalate & NM & NM \\
\hline $\mathrm{P}$ & 0.111 & $<0.01$ & Phosphate & $<100$ & $<100$ \\
\hline $\mathrm{Pb}$ & $<0.01$ & $<0.01$ & Carbonate & 1,338 & 2,485 \\
\hline S & 0.158 & 0.138 & Other Results & & \\
\hline $\mathrm{Si}$ & $<0.10$ & 0.022 & $\begin{array}{c}\text { Base } \\
\text { Equivalents } \\
\text { (molar) }\end{array}$ & 0.632 & 0.909 \\
\hline $\mathrm{Ti}$ & $<0.01$ & $<0.01$ & $\begin{array}{l}\text { Slurry Density } \\
\qquad(\mathrm{g} / \mathrm{ml})\end{array}$ & 1.09 & 1.11 \\
\hline $\mathrm{Zn}$ & $<0.01$ & $<0.01$ & $\mathrm{pH}$ & 13.4 & 13.5 \\
\hline $\mathrm{Zr}$ & $<0.01$ & $<0.01$ & & & \\
\hline
\end{tabular}

Noble metals, mercury, and rinse water were added to the sludge simulant prior to performing the SRAT cycle; however mercury was not added to SB5-15 until after the ARP addition and concentration were completed to avoid potential issues with dimethyl mercury formation. 
Samples were not taken after the additions as the amount of these additions is small compared to the sludge, except in the case of the ARP addition. The noble metal concentrations were based on $110 \%$ of the estimated amount in the sludge batch ${ }^{7}$. The concentrations of each trim chemical added are shown in Table 3.

Table 3. Trim Chemical Additions, wt \% on Total Solids Basis

\begin{tabular}{||l|c|c|c||}
\hline \multicolumn{1}{|c|}{ Trim Chemical } & $\begin{array}{c}\text { SB5-C } \\
\text { Without } \\
\text { ARP/MCU }\end{array}$ & $\begin{array}{c}\text { SB5-C* } \\
\text { With } \\
\text { ARP/MCU }\end{array}$ & SB5-D \\
\hline Trimmed Sludge Target Ag metal content & 0.01375 & 0.01375 & 0.01328 \\
\hline Trimmed Sludge Target Hg metal content & 2.3752 & 1.6880 & 2.7149 \\
\hline Trimmed Sludge Target Pd metal content & 0.00362 & 0.00362 & 0.00448 \\
\hline Trimmed Sludge Target Rh metal content & 0.02266 & 0.02266 & 0.02325 \\
\hline Trimmed Sludge Target Ru metal content & 0.09801 & 0.09801 & 0.10800 \\
\hline
\end{tabular}

* The sludge was added at the same concentration of noble metals for runs with and without ARP. However, no mercury was added with the ARP waste, which effectively decreased the mercury concentration in the SRAT receipt sample by $29 \%$.

\subsection{Experimental Apparatus}

The testing was performed at the ACTL using the four-liter kettle setup. The SRAT rigs were assembled following the guidelines of SRNL-PSE-2006-00074. The intent of the equipment is to functionally replicate the DWPF processing vessels. The 4-liter glass kettle is used to replicate both the SRAT and the SME, and it is connected to the SRAT Condenser, the Mercury Water Wash Tank (MWWT), and the Formic Acid Vent Condenser (FAVC). The Slurry Mix Evaporator Condensate Tank (SMECT) is represented by a sampling bottle that is used to remove condensate through the MWWT. For the purposes of this paper, the condensers and wash tank are referred to as the offgas components. A sketch of the experimental setup is given as Figure 1. 


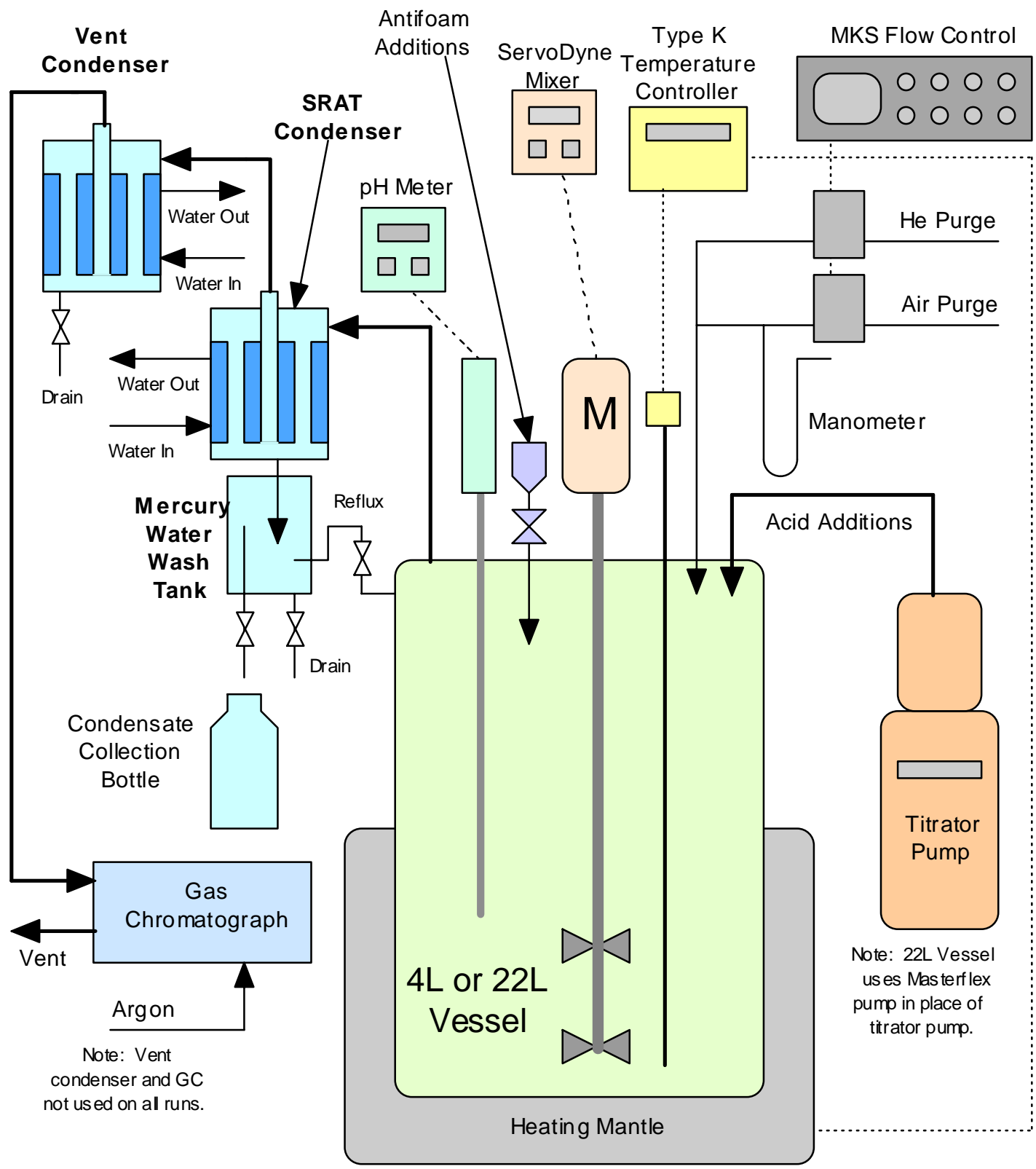

Figure 1. Schematic of SRAT Equipment Set-Up

SRAT and SME processing parameters are summarized in Appendix A. The flowsheet runs were performed using the guidance of Procedure ITS-0094 ("Laboratory Scale Chemical Process Cell Simulations") of Manual L29 . Offgas hydrogen, oxygen, nitrogen, nitrous oxide, and carbon dioxide concentrations were measured during the experiments using in-line instrumentation. Helium was introduced at a concentration of $0.5 \%$ of the total air purge as an inert tracer gas so that total amounts of generated gas and peak generation rates could be calculated. During the runs, the kettle was monitored to observe reactions that were occurring to include foaming, air entrainment, rheology changes, loss of heat transfer capabilities, and offgas carryover. 
Observations were recorded in laboratory notebook WSRC-NB-2008-00015 $5^{10}$ and are discussed in Section 3.0.

An ARP and MCU simulant were added to the SB5-15 run. The ARP simulant was added to the sludge before the ARP simulant is concentrated so the SRAT receipt sample is approximately the same total solids content as the sludge. ARP was added to the SB5-C sludge at boiling. The MCU simulant was added during the boiling phase of the SRAT cycle at a scaled rate approximately equal to the maximum steam flow of $5000 \mathrm{lb} / \mathrm{hr}$.

Concentrated nitric acid (50-wt $\%)$ and formic acid $(90-\mathrm{wt} \%)$ were used to acidify the sludge and perform neutralization and reduction reactions during processing. The amounts of acid to add for each run were determined using the existing DWPF acid addition equation ${ }^{11}$. The split of the acid was determined using the redox equation currently being used in DWPF processing ${ }^{12}$. The redox target $\left(\mathrm{Fe}^{2+} / \Sigma \mathrm{Fe}\right)$ was 0.2 . To account for the reactions and anion destructions that occur during processing, assumptions about nitrite destruction, nitrite to nitrate conversion, and formate destruction were made for each run. The values used for each run are provided in Section 3.0.

To prevent foaming during the ARP concentration (caustic boiling phase), $200 \mathrm{ppm}$ of IIT antifoam was added before processing. To prevent foaming during SRAT processing, $200 \mathrm{ppm}$ IIT 747 antifoam was added before acid addition, $100 \mathrm{ppm}$ was added after nitric acid addition was complete and $500 \mathrm{ppm}$ was added at the completion of formic acid addition. SRAT processing included 18-hours at boiling (dewater time plus reflux time). In SB5-15, SRAT processing included dewatering time plus MCU addition/dewatering time (about 14 hours). In five of the runs, SME processing did not include the addition of canister dewaters. In the other four, SME processing included the addition of five canister dewaters. The frit addition was split into two equal portions. The frit was added with water and formic acid at DWPF prototypical conditions. Concentration was performed after each frit addition and then heat was removed to allow for the next frit addition A final concentration was performed at the end of the run to meet the target total solids. The SRAT condenser was maintained at $25^{\circ} \mathrm{C}$ during the run while the vent condenser was maintained at $4^{\circ} \mathrm{C}$.

\subsection{Analytical Methods}

Sample request forms were used for samples to be analyzed, and analyses followed the guidelines for the task. A unique lab identification number was assigned to each sample for tracking purposes. Analyses were performed using approved analytical and Quality Assurance (QA) procedures.

The sludge simulant was analyzed as part of the sludge fabrication process; therefore, those results were used to support this testing and no discussion of the methods will be presented here. The ARP simulant analysis paralleled that of the two sludge simulants. The samples were analyzed at the PSAL and AD. The PSAL performed analyses on the in-process and product samples to determine the chemical composition, total and dissolved solids, density, and $\mathrm{pH}$. The chemical composition was determined in duplicate by calcining the samples at $1100^{\circ} \mathrm{C}$ and then digesting the product using $\mathrm{Na}_{2} \mathrm{O}_{2} / \mathrm{NaOH}$ fusion, a lithium metaborate fusion, and mixed acid method. The preparations were then analyzed using Inductively Coupled Plasma - Atomic Emission Spectroscopy (ICP-AES) to measure the cations present.

Sludge samples for anion analyses were prepped using weighted dilutions (diluting the slurry with water) and were analyzed using Ion Chromatography (IC). The in-process supernates were also analyzed on the IC to determine the soluble anions. The total and dissolved solids were 
measured on two aliquots and the insoluble and soluble solids fractions were calculated from the results. Density and $\mathrm{pH}$ measurements of the samples were also performed on the in-process samples. Rheological properties of the SRAT and SME products (yield stress and plastic viscosity) were measured and evaluated as a function of the test conditions.

The Total Inorganic Carbon (TIC) and mercury analysis were performed by Analytical Development. TIC was analyzed with an OI 1010 High Temperature Total Carbon Analyzer. Mercury was analyzed using Atomic Adsorption Spectroscopy following an aqua regia preparation. The mercury slurry samples were pulled directly into the digestion bottle to minimize the risk of sampling issues effecting results.

Gases were monitored during the runs using high-speed Agilent model 3000 micro Gas Chromatographs (GC) to provide insight into the reactions occurring during processing and to determine whether a flammable mixture was formed. As mentioned above, helium was used as a purge gas tracer. One calibration standard was used to calibrate the GCs before each run to attempt to bound the quantities of the expected gases. The concentration of this calibration standard was $0.5 \mathrm{~mol} \%$ helium, $1 \mathrm{~mol} \%$ hydrogen, $20 \%$ oxygen, $2.5 \mathrm{~mol} \%$ nitrous oxide, 0.5 mol\% carbon monoxide, and $20 \mathrm{~mol} \%$ carbon dioxide with the balance nitrogen. A second calibration point for nitrogen used room air. Calibration checks were performed before and after each run.

The GC is self-contained and is designed specifically for fast and accurate analysis. The GCs have five main components. The first is the carrier gas (argon for this testing) to transport the sample through the MolSieve 5A PLOT (Channel A) and PLOT Q (Channel B) columns. The second is the injector, which introduces a measured amount of sample into the inlet of the analytical columns where it is separated. The third component is the column, which is the capillary tubing coated or packed with a chemical substance known as the stationary phase that preferentially attracts the sample components. As a result, components separate as they pass through the column based on their solubility. Since solubility is affected by temperature, column temperature is controlled during the run. Channel A separates helium, hydrogen, nitrogen, oxygen, nitric oxide and carbon monoxide and Channel B separates carbon dioxide and nitrous oxide. The fourth component is a micro-machine thermo conductivity detector. The solid state detector monitors the carrier and senses a change in its composition when a component in the sample elutes from the column. The fifth component is the computer data acquisition system, Cerity software. Its main purpose is to generate both qualitative and quantitative data. It provides a visual recording of the detector output and an area count of the detector response. The detector response is used to identify the sample composition and measure the amount of each component by comparing the area counts of the sample to the analysis of known calibration standards. A sample was taken approximately once every 4.5 minutes. 


\subsection{Results}

Four SRAT/SME cycles with SB-5 batch simulant and five SRAT/SME cycles with SB-5 blend simulant were conducted during this study, as shown in Table $4 \mathrm{c}$ and Table $4 \mathrm{~d}$. Table numbering started at $4 \mathrm{c}$ to correspond to runs using the SB5-C blend simulant and $4 \mathrm{~d}$ to refer to runs with the SB5-D batch simulant. Numbering of tables throughout this report is consistent with this methodology. A unique run number was assigned to each run ${ }^{13,14}$. All runs targeted a predicted glass REDOX $\left(\mathrm{Fe}^{2+} / \Sigma \mathrm{Fe}\right)$ of 0.2 by adjusting the ratio of formic to nitric acid during the SRAT cycle and assumed the current REDOX equation. Frit 418 was utilized during the SME cycle and a waste loading of $35 \%$ was targeted.

Table 4c. SB5 Blend (SB5-C) SRAT/SME Tests

\begin{tabular}{||c|c|c|c|c||}
\hline $\begin{array}{c}\text { RUN } \\
\text { NUMBER }\end{array}$ & $\begin{array}{c}\text { ACID } \\
\text { STOICHIOMETRY }\end{array}$ & $\begin{array}{c}\text { REDOX } \\
\text { TARGET }\end{array}$ & $\begin{array}{c}\text { PROCESS } \\
\text { FRIT }\end{array}$ & $\begin{array}{c}\text { WASTE } \\
\text { LOADING }\end{array}$ \\
\hline SB5-11 & $115 \%$ & 0.2 & 418 & 35 \\
\hline SB5-12 & $130 \%$ & 0.2 & 418 & 35 \\
\hline SB5-13 & $145 \%$ & 0.2 & 418 & 35 \\
\hline SB5-14 & $160 \%$ & 0.2 & 418 & 35 \\
\hline SB5-15 & $130 \%$ & 0.2 & 418 & 35 \\
\hline
\end{tabular}

Table 4d. SB5 Batch (SB5-D) SRAT/SME Tests

\begin{tabular}{||c|c|c|c|c||}
\hline $\begin{array}{c}\text { RUN } \\
\text { NUMBER }\end{array}$ & $\begin{array}{c}\text { ACID } \\
\text { STOICHIOMETRY }\end{array}$ & $\begin{array}{c}\text { REDOX } \\
\text { TARGET }\end{array}$ & $\begin{array}{c}\text { PROCESS } \\
\text { FRIT }\end{array}$ & $\begin{array}{c}\text { WASTE } \\
\text { LOADING }\end{array}$ \\
\hline SB5-7 & $115 \%$ & 0.2 & 418 & 35 \\
\hline SB5-8 & $130 \%$ & 0.2 & 418 & 35 \\
\hline SB5-9 & $145 \%$ & 0.2 & 418 & 35 \\
\hline SB5-10 & $160 \%$ & 0.2 & 418 & 35 \\
\hline
\end{tabular}

\subsection{SRAT Cycle Results}

\subsubsection{Acid Addition Calculation}

\subsubsection{Calculation Inputs}

The SRAT cycle acid calculation utilizes the amount of nitrite, mercury, manganese, carbonate, and base equivalents to calculate the stoichiometric amount of acid to be added. Nitric acid and formic acid amounts are calculated based on the applied stoichiometric factor and the ratio needed to achieve the predicted glass redox target of $0.2 \mathrm{Fe}^{+2} / \Sigma \mathrm{Fe}$. The equation for prediction of glass redox utilizes estimates of the amount of formate, oxalate, nitrate, nitrite, manganese, and total solids in the SME product. The estimation of the final concentration for the anions requires assumptions to be made concerning how these species will react during the SRAT and SME cycles. Formate and oxalate are destroyed by reactions with oxidizing species and by catalytic reactions with noble metals. Nitrite is typically consumed during acid additions, but can react to form different species including nitrate. The acid calculation inputs and assumptions are shown in Table 5, Table 6, and Table 7 for SB5-7 and SB5-11. The same assumptions and inputs were used for all four runs, with the exception of the acid stoichiometry. 
SRNS-STI-2008-00024

Revision 0

Table 5. Acid Calculation Inputs

\begin{tabular}{||l|c|c|c||}
\hline Description & Units & $\begin{array}{c}\text { SB5- } \\
\mathbf{1 1}^{\mathbf{a}}\end{array}$ & SB5-7 $^{\mathbf{b}}$ \\
\hline Sludge & & $\begin{array}{c}\text { SB5-C } \\
\text { Blend }\end{array}$ & $\begin{array}{c}\text { SB5-D } \\
\text { Batch }\end{array}$ \\
\hline Fresh Sludge Mass without trim chemicals & $\mathrm{g}$ slurry & $3,500.0$ & $3,017.9$ \\
\hline Fresh Sludge Weight \% Total Solids & $\mathrm{wt} \%$ & 12.47 & 15.09 \\
\hline Fresh Sludge Weight \% Calcined Solids & $\mathrm{wt} \%$ & 9.51 & 11.25 \\
\hline Fresh Sludge Weight \% Insoluble Solids & $\mathrm{wt} \%$ & 7.85 & 7.95 \\
\hline Fresh Sludge Density & $\mathrm{mg} / \mathrm{kg}$ slurry & 1.090 & 1.117 \\
\hline Fresh Sludge Nitrite & $\mathrm{mg} / \mathrm{kg}$ slurry & 3,940 & 7,114 \\
\hline Fresh Sludge Nitrate & $\mathrm{mg} / \mathrm{kg}$ slurry & 287.5 & 0 \\
\hline Fresh Sludge Oxalate & $\mathrm{mg} / \mathrm{kg}$ slurry & 0 & 0 \\
\hline Fresh Sludge Formate & $\mathrm{wt} \%$ calcined basis & 5.050 & 4.639 \\
\hline Fresh Sludge Manganese (\% of Calcined Solids) & $\mathrm{mg} / \mathrm{kg}$ slurry & 1,338 & 2,470 \\
\hline Fresh Sludge Slurry TIC (treated as Carbonate) & Equiv Moles Base/L & 0.632 & 0.909 \\
\hline $\begin{array}{l}\text { Fresh Sludge Hydroxide (Base Equivalents) pH }=7 \\
\text { Fresh Sludge Mercury (\% of Total Solids in untrimmed } \\
\text { sludge) }\end{array}$ & $\mathrm{wt} \%$ dry basis & 0.0000 & 0.0000 \\
\hline Fresh Sludge Supernate manganese & $\mathrm{mg} / \mathrm{L}$ supernate & 0 & 0 \\
\hline Fresh Sludge Supernate density & $\mathrm{kg} / \mathrm{L}$ supernate & 1.024 & 1.06 \\
\hline \hline
\end{tabular}

SB5-15 was similar to SB5-11, 3499.6 g slurry, after the ARP addition and boil-down were completed. It had similar wt $\%$ total solids, but different concentrations of base, TIC, nitrite, and Mn. The non-aqueous fraction of SB5-15 was about $72 \%$ SB5-C Blend simulant solids and 28\% ARP simulant solids.

\footnotetext{
a The same parameters were used for runs SB5-11, SB5-12, SB5-13, and SB-14, with the exception of acid stoichiometry.

${ }^{\mathrm{b}}$ The same parameters were used for runs SB5-7, SB5-8, SB5-9, and SB-10, with the exception of acid stoichiometry.
} 
SRNS-STI-2008-00024

Revision 0

Table 6. SRAT Cycle Processing Parameters and Assumptions

\begin{tabular}{|c|c|c|c|}
\hline Description & \multirow[t]{2}{*}{ Units } & SB5-11 & SB5-7 \\
\hline Sludge & & $\begin{array}{l}\text { SB5-C } \\
\text { Blend }\end{array}$ & $\begin{array}{l}\text { SB5-D } \\
\text { Batch }\end{array}$ \\
\hline Conversion of Nitrite to Nitrate in SRAT Cycle & $\mathrm{gmol} \mathrm{NO}_{3}{ }^{-} / 100 \mathrm{gmol} \mathrm{NO}_{2}^{-}$ & 15.00 & 25.00 \\
\hline Destruction of Nitrite in SRAT and SME cycle & $\%$ of starting nitrite & 100.00 & 100.00 \\
\hline Destruction of Formic acid charged in SRAT & $\%$ & 30.00 & 15.00 \\
\hline Destruction of oxalate charged & $\%$ & 50.00 & 50.00 \\
\hline Percent Acid in Excess Stoichiometric Ratio & $\%$ & 115.00 & 115.00 \\
\hline SRAT Product Target Solids & $\%$ & 25.00 & 25.00 \\
\hline Nitric Acid Molarity & Molar & 10.534 & 10.534 \\
\hline Formic Acid Molarity & Molar & 23.600 & 23.600 \\
\hline Scaled Nitric Acid addition Rate & gallons per minute & 2.0 & 2.0 \\
\hline Scaled Formic Acid addition Rate & gallons per minute & 2.0 & 2.0 \\
\hline REDOX Target & $\mathrm{Fe}^{+2} / \Sigma \mathrm{Fe}$ & 0.200 & 0.200 \\
\hline Trimmed Sludge Target Ag metal content & total $\mathrm{wt} \%$ dry basis & 0.01375 & 0.01328 \\
\hline Trimmed Sludge Target wt $\%$ Hg dry basis & total $\mathrm{wt}^{\%} \%$ dry basis & 2.37520 & 2.71490 \\
\hline Trimmed Sludge Target Pd metal content & total $\mathrm{wt} \%$ dry basis & 0.00362 & 0.00448 \\
\hline Trimmed Sludge Target Rh metal content & total $\mathrm{wt} \%$ dry basis & 0.02266 & 0.02325 \\
\hline Trimmed Sludge Target Ru metal content & total wt $\%$ dry basis & 0.09801 & 0.10800 \\
\hline Water to dilute fresh sludge and/or rinse trim chemicals & $\mathrm{g}$ & 50.000 & 50.000 \\
\hline Mass of SRAT cycle samples & $\mathrm{g}$ & 200.000 & 200.000 \\
\hline Wt\% Active Agent In Antifoam Solution & $\%$ & 10 & 10 \\
\hline $\begin{array}{l}\text { Basis Antifoam Addition for SRAT (generally } 100 \mathrm{mg} \\
\text { antifoam/kg slurry) }\end{array}$ & $\mathrm{mg} / \mathrm{kg}$ slurry & 100.00 & 100.00 \\
\hline Number of basis antifoam additions added during SRAT & & & 8 \\
\hline
\end{tabular}

Table 7. SME Processing Parameters and Assumptions

\begin{tabular}{|c|c|c|c|}
\hline Description & \multirow[t]{2}{*}{ Units } & SB5-11 & SB5-7 \\
\hline Sludge & & $\begin{array}{l}\text { SB5-C } \\
\text { Blend }\end{array}$ & $\begin{array}{c}\text { SB5-D } \\
\text { Batch }\end{array}$ \\
\hline Frit type & & 418.00 & 418.00 \\
\hline Destruction of Formic acid in SME & $\%$ & 7.00 & 7.00 \\
\hline Destruction of Nitrate in SME & $\%$ & 0.00 & 0.00 \\
\hline Assumed SME density & $\mathrm{kg} / \mathrm{L}$ & 1.45 & 1.45 \\
\hline Basis Antifoam Addition for SME cycle & $\mathrm{mg} / \mathrm{kg}$ slurry & 100.00 & 100.00 \\
\hline \multicolumn{2}{|c|}{ Number of basis antifoam additions added during SME cycle } & 4 & 4 \\
\hline Sludge Oxide Contribution in SME (Waste Loading) & $\%$ & 35.000 & 35.000 \\
\hline Frit Slurry Formic Acid Ratio & g $90 \mathrm{wt} \%$ FA/100 g Frit & 1.5 & 1.5 \\
\hline Target SME Solids total $\mathrm{Wt} \%$ & $\mathrm{wt} \%$ & 45.0 & 45.0 \\
\hline Number of frit additions in SME Cycle & & 2.000 & 2.000 \\
\hline
\end{tabular}




\subsubsection{Acid Calculation Results}

The acid calculation determines the values for a large number of processing parameters as well as the amount of formic and nitric acid to be used. Selected values are shown in Table $8 \mathrm{c}$ and Table 8d. The stoichiometric acid addition for the sludge simulant was calculated to be 1.12 moles per liter for SB5-C and 1.71 moles per liter for SB5-D. As acid stoichiometry increased, the ratio of formic acid to the total amount of acid decreased. This decrease is due to the presence of nitrate and nitrite in the initial sludge simulant lowering the amount of nitrate or oxidizers needed to balance the formic acid at lower acid stoichiometries. The frit addition increased slightly due to the process samples being more dilute in terms of the original feed as acid stoichiometry increased.

Table 8c. Selected Process Values for Testing with Blend Sludge SB5-C

\begin{tabular}{||c|c|c|c||}
\hline $\begin{array}{c}\text { ACID } \\
\text { STOICHIOMETRY }\end{array}$ & $\begin{array}{c}\text { TOTAL ACID } \\
\text { REQUIRED } \\
\text { (MOL/L) }\end{array}$ & $\begin{array}{c}\text { FORMIC ACID RATIO } \\
\text { (\% OF TOTAL ACID) }\end{array}$ & $\begin{array}{c}\text { FRIT ADDITION } \\
\text { AMOUNT } \\
\text { (GRAMS) }\end{array}$ \\
\hline $115 \%$ & 1.28 & $88 \%$ & 560.59 \\
\hline $130 \%$ & 1.45 & $84 \%$ & 563.11 \\
\hline $\begin{array}{c}130 \% \text { with } \\
\text { ARP/MCU }\end{array}$ & 1.22 & $86 \%$ & 531.25 \\
\hline $145 \%$ & 1.62 & $84 \%$ & 566.41 \\
\hline $160 \%$ & 1.79 & $83 \%$ & 568.41 \\
\hline
\end{tabular}

Less acid and frit were required in the test with ARP/MCU than in the $130 \%$ test without $\mathrm{ARP} / \mathrm{MCU}$ because the concentrated ARP slurry had a lower acid demand per unit volume than an equivalent mass of SB5 simulant, and because the calcined solids fraction of the ARP total solids was lower than that of the SB5 simulant solids.

Table 8d. Selected Process Values for Testing with Batch Sludge SB5-D

\begin{tabular}{||c|c|c|c||}
\hline $\begin{array}{c}\text { ACID } \\
\text { STOICHIOMETRY }\end{array}$ & $\begin{array}{c}\text { TOTAL ACID } \\
\text { REQUIRED } \\
\text { (MOL/L) }\end{array}$ & $\begin{array}{c}\text { FORMIC ACID RATIO } \\
\text { (\% OF TOTAL ACID) }\end{array}$ & $\begin{array}{c}\text { FRIT ADDITION } \\
\text { AMOUNT } \\
\text { (GRAMS) }\end{array}$ \\
\hline $115 \%$ & 1.96 & $85 \%$ & 579.14 \\
\hline $130 \%$ & 2.22 & $84 \%$ & 581.87 \\
\hline $145 \%$ & 2.48 & $83 \%$ & 584.33 \\
\hline $160 \%$ & 2.73 & $82 \%$ & 586.58 \\
\hline
\end{tabular}

\subsubsection{Processing Observations}

Overall processing during the testing went smoothly with no interruptions or upsets occurring during process runs. The sludge became less viscous during acid additions and no problems were noted with mixing during the runs. Agitator speeds of $250 \mathrm{RPM}^{\mathrm{c}}$ were needed to mix the sludge simulants.

\footnotetext{
${ }^{c}$ The mixing geometry of the lab-scale apparatus is not prototypic and mixing was adjusted as required during testing to ensure that the process chemistry is captured. Agitator speed is reported only to give an indication of changes in rheological properties during the testing.
} 


\subsubsection{Foaming}

No additional antifoam was required during any of the nine experiments. No foaming problems were noted during SRAT or SME processing.

\subsubsection{2 pH Profiles}

The $\mathrm{pH}$ profiles of six of the eight runs in general matched profiles noted during previous CPC simulations. As shown in Figure 2, the $\mathrm{pH}$ of the runs was lower for runs with higher acid additions. Also, acid addition took longer for the runs with the batch simulant (SB5-7 to 10) due to the higher acid demand. The blend simulant had significantly lower acid demand due to the dilution by pump leakage in Tank 40. Formic acid decomposition during high acid runs can result in lower $\mathrm{pH}$ at higher acid stoichiometries, but the decomposition noted during the flowsheet testing was not high enough to raise the $\mathrm{pH}$ of the higher acid runs above the lower acid runs in the SRAT cycle. All three runs with acid stoichiometries above $115 \%$ had a minimum $\mathrm{pH}$ near 4.0 at the end of acid addition. No data is included for runs SB5-11 and SB5-14 because $\mathrm{pH}$ probe breakage occurred very early in the runs and the recorded data was not meaningful.

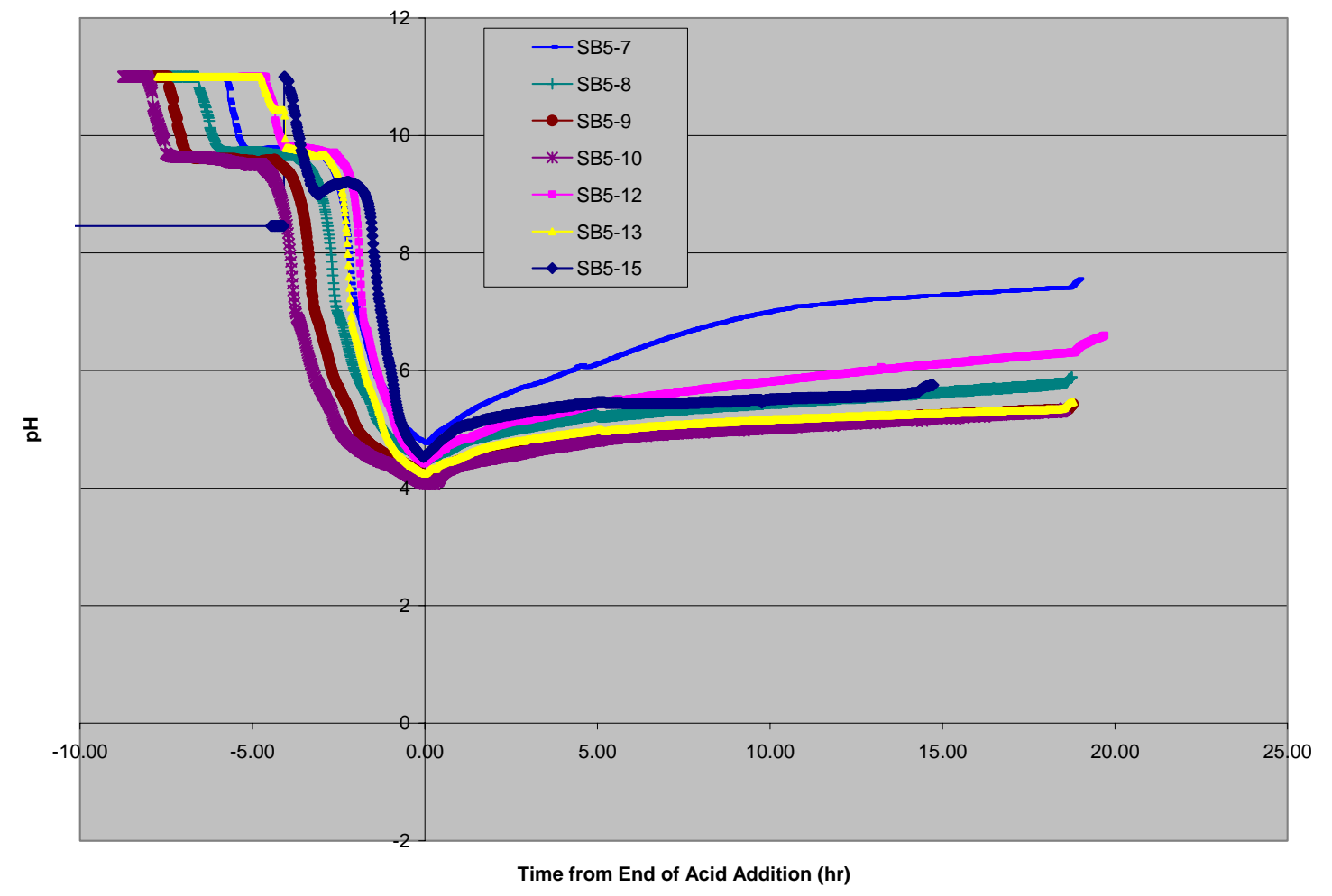

Figure 2. SB5 Flowsheet Testing pH Profiles

\subsubsection{SRAT Cycle Sample Results}

Samples were pulled at the conclusion of the SRAT cycle. The total solids, mercury, anions, and soluble elemental species were analyzed for all samples. Samples were taken of the SRAT dewater and the MWWT contents at the completion of the SRAT cycle. All sample results are tabulated in Appendix A-2. 


\subsubsection{Nitrite, Nitrate, Formate}

Nitrite destruction met the process requirement of $<1000 \mathrm{mg} / \mathrm{kg}$ at the end of the SRAT cycle for all runs and was $100 \%$ complete for all runs. Note that the total time at boiling was 18 hours for each of these experiments due to the high mercury concentration. The longer boiling time may have led to the complete nitrite destruction, even for the lowest acid stoichiometry runs. Anion results are summarized in Table $9 \mathrm{c}$ and $\mathrm{d}$.

Table 9c. SRAT Product Anion Concentration from Tests with Blend Sludge SB5-C, mg/kg

\begin{tabular}{||c|c|c|c|c|c|c|c|c||}
\hline \hline Acid Stoichiometry & Sample \#08- & $\mathbf{F}$ & $\mathrm{CL}$ & $\mathrm{NO}_{2}$ & $\mathrm{NO}_{3}$ & $\mathrm{SO}_{4}$ & $\mathrm{PO}_{4}$ & $\mathrm{HCO}_{2}$ \\
\hline $115 \%$ & SB5-11-2534 & $<100$ & 356 & $<100$ & 20,600 & $<100$ & $<100$ & 62,250 \\
\hline $130 \%$ & SB5-12-2545 & $<100$ & 329 & $<100$ & 23,600 & $<100$ & $<100$ & 58,200 \\
\hline $145 \%$ & SB5-13-2557 & $<100$ & 332 & $<100$ & 26,150 & 108 & $<100$ & 61,700 \\
\hline $160 \%$ & SB5-14-2568 & $<100$ & 342 & $<100$ & 28,600 & 185 & $<100$ & 74,400 \\
\hline $130 \%$ ARP/MCU & SB5-15-2584 & $<100$ & 350 & $<100$ & 27,950 & 2100 & $<100$ & 57,200 \\
\hline
\end{tabular}

Table 9d. SRAT Product Anion Concentration from Tests with Batch Sludge SB5-D, mg/kg

\begin{tabular}{||c|c|c|c|c|c|c|c|c||}
\hline Acid Stoichiometry & Sample \#08- & $\mathbf{F}$ & $\mathrm{Cl}$ & $\mathrm{NO}_{2}$ & $\mathrm{NO}_{3}$ & $\mathrm{SO}_{4}$ & $\mathbf{P O}_{4}$ & $\mathrm{HCO}_{2}$ \\
\hline $115 \%$ & SB5-7-2505 & $<100$ & 316 & $<100$ & 29,550 & $<100$ & $<100$ & 62,200 \\
\hline $130 \%$ & SB5-8-2487 & $<100$ & 338 & $<100$ & 31,250 & 153 & $<100$ & 67,400 \\
\hline $145 \%$ & SB5-9-2516 & $<100$ & 325 & $<100$ & 34,850 & 194 & $<100$ & 71,700 \\
\hline $160 \%$ & SB5-10-2496 & $<100$ & 312 & $<100$ & 38,100 & 282 & $<100$ & 77,700 \\
\hline
\end{tabular}

In a typical run, approximately one-third of the nitrite is converted to nitrate and the other twothirds are converted to $\mathrm{NO}_{\mathrm{x}}$ and $\mathrm{N}_{2} \mathrm{O}$. In the majority of these runs (Table 10), no additional nitrate was present in the SRAT product due to the destruction of nitrate. A negative nitrite to nitrate conversion number is the result of not only complete nitrite destruction but also nitrate destruction. Numbers between $-10 \%$ and $+10 \%$ may be due to analytical error but larger numbers are due to significant nitrate destruction. The presence of sulfate from the concentrated ARP stream was clearly evident in the anion data.

Formate is destroyed by reduction of $\mathrm{Mn}, \mathrm{Hg}$ and catalytic destruction of formic acid to produce $\mathrm{NO}, \mathrm{N}_{2} \mathrm{O}$, and hydrogen. An overall trend of higher formate loss with higher acid stoichiometry is indicated which matches previous results and the amount of formate loss is consistent with previous testing ${ }^{4,15}$.

Table 10c. SRAT Anion Conversions from Tests with Blend Sludge SB5-C, mg/kg

\begin{tabular}{|c|c|c|c|}
\hline \multirow[b]{2}{*}{ Acid Stoichiometry } & \multicolumn{3}{|c|}{ SRAT Cycle } \\
\hline & $\begin{array}{c}\text { Formate } \\
\text { Destruction }\end{array}$ & $\begin{array}{c}\text { Nitrite } \\
\text { Destruction }\end{array}$ & $\begin{array}{l}\text { Nitrite to } \\
\text { Nitrate } \\
\text { Conversion }\end{array}$ \\
\hline $115 \%$ & $24 \%$ & $>99.5 \%$ & $-16 \%$ \\
\hline $130 \%$ & $29 \%$ & $>99.5 \%$ & $-27 \%$ \\
\hline $145 \%$ & $30 \%$ & $>99.5 \%$ & $-31 \%$ \\
\hline $160 \%$ & $16 \%$ & $>99.5 \%$ & $-14 \%$ \\
\hline 130\% ARP/MCU & $15 \%$ & $>99.5 \%$ & $15 \%$ \\
\hline
\end{tabular}


Table 10d. SRAT Product Anion Conversions from Tests with Batch Sludge SB5-D, mg/kg

\begin{tabular}{||c||c|c|c||}
\hline \multicolumn{1}{|c||}{$\begin{array}{c}\text { Acid } \\
\text { Stoichiometry }\end{array}$} & $\begin{array}{c}\text { Formate } \\
\text { Destruction }\end{array}$ & $\begin{array}{c}\text { Nitrite } \\
\text { Destruction }\end{array}$ & $\begin{array}{c}\text { Nitrite to } \\
\text { Nitrate } \\
\text { Conversion }\end{array}$ \\
\hline $115 \%$ & 134 & $>99.5$ & 30 \\
\hline $130 \%$ & 29 & $>99.5$ & -17 \\
\hline $145 \%$ & 24 & $>99.5$ & 2 \\
\hline $160 \%$ & 26 & $>99.5$ & -4 \\
\hline
\end{tabular}

\subsubsection{Mercury}

The SRAT product samples were analyzed for mercury content to evaluate the stripping of mercury during the SRAT cycle. The SRAT product must be below $0.45 \mathrm{wt} \%$ (solids basis) mercury to meet process specifications. Previous sludge batches except SB1B and SB4 met this requirement without mercury removal, but SB5 is estimated to contain approximately $2.5 \mathrm{wt} \%$ mercury in the incoming blended feed. As shown in Table $11 \mathrm{c}$ and d, the mercury was reduced to acceptable levels by the end of the SRAT cycle for all but two runs.

Table 11c. SRAT Product Mercury Results from Tests with Blend Sludge SB5-C

\begin{tabular}{||c|c||}
\hline Acid Stoichiometry & $\begin{array}{c}\text { SRAT Product Mercury, } \\
\text { wt \% total solids basis }\end{array}$ \\
\hline $115 \%$ & 0.984 \\
\hline $130 \%$ & 0.927 \\
\hline $145 \%$ & 0.146 \\
\hline $160 \%$ & 0.052 \\
\hline $130 \%$ ARP/MCU & 0.042 \\
\hline
\end{tabular}

Table 11d. SRAT Product Mercury Results from Tests with Batch Sludge SB5-D

\begin{tabular}{||c|c||}
\hline Acid Stoichiometry & $\begin{array}{c}\text { SRAT Product Mercury, } \\
\text { wt \% total solids basis }\end{array}$ \\
\hline $115 \%$ & 0.213 \\
\hline $130 \%$ & 0.163 \\
\hline $145 \%$ & 0.041 \\
\hline $160 \%$ & 0.063 \\
\hline
\end{tabular}

The mercury stripping is controlled by the boilup rate and the time at boiling. The simulant testing was completed at a scaled-down maximum boilup rate equivalent to $5000 \mathrm{lb} / \mathrm{hr}$ steam. Time at boiling was calculated assuming it takes $750 \mathrm{lb}$ of steam to strip each $\mathrm{lb}$ of mercury to reduce the SRAT product to $0.45 \mathrm{wt} \% \mathrm{Hg}$. As a result, all eight non-ARP/MCU runs had 18 hours at boiling during the SRAT cycle. The total boilup was 13,500 lb of steam. If DWPF uses a lower boilup rate, they may need to extend the boiling time to meet the mercury limit. SB5-15 with ARP/MCU had 28\% less initial mercury than the other four runs with SB5-C simulant, since only the SB5-C simulant portion was trimmed to $2.2375 \mathrm{wt} \% \mathrm{Hg}$. The ARP was assumed to be free of $\mathrm{Hg}$ in order to better test the hydrogen limit with SB5-15. Only 13 hours of boiling at the 
maximum boil-up rate were predicted to successfully strip $\mathrm{Hg}$ in SB5-15, but 14 hours were required for dewatering and $\mathrm{MCU}$ addition. Therefore, dewatering and $\mathrm{MCU}$ addition controlled the duration of SB5-15 rather than mercury removal.

The two runs that exceeded the DWPF mercury limit were both low acid runs with the blend simulant. The blend simulant is low in anions due to dilution in Tank 40, which contributed to a low acid demand. If DWPF has problems achieving the mercury limit, a higher acid stoichiometry may improve mercury removal. However, it may also lead to higher hydrogen generation. Note also that the simulant testing was completed without a heel so the starting mercury concentration will be lower in DWPF as the heel will dilute the raw sludge.

\subsubsection{Condensates}

The sample results for all condensate samples are tabulated in Appendix A. Higher acid stoichiometry lowers the $\mathrm{pH}$ of the SRAT slurry.

Condensate $\mathrm{pH}$ was higher as acid stoichiometry was increased, as shown in Figure 3. The condensate $\mathrm{pH}$ of the $130 \%$ run was basic at the end of the SRAT cycle as indicated by the $\mathrm{pH}$ of the MWWT results. The MWWT was drained at the end of the SRAT cycle and (generally) represents the last condensate generated during that cycle.

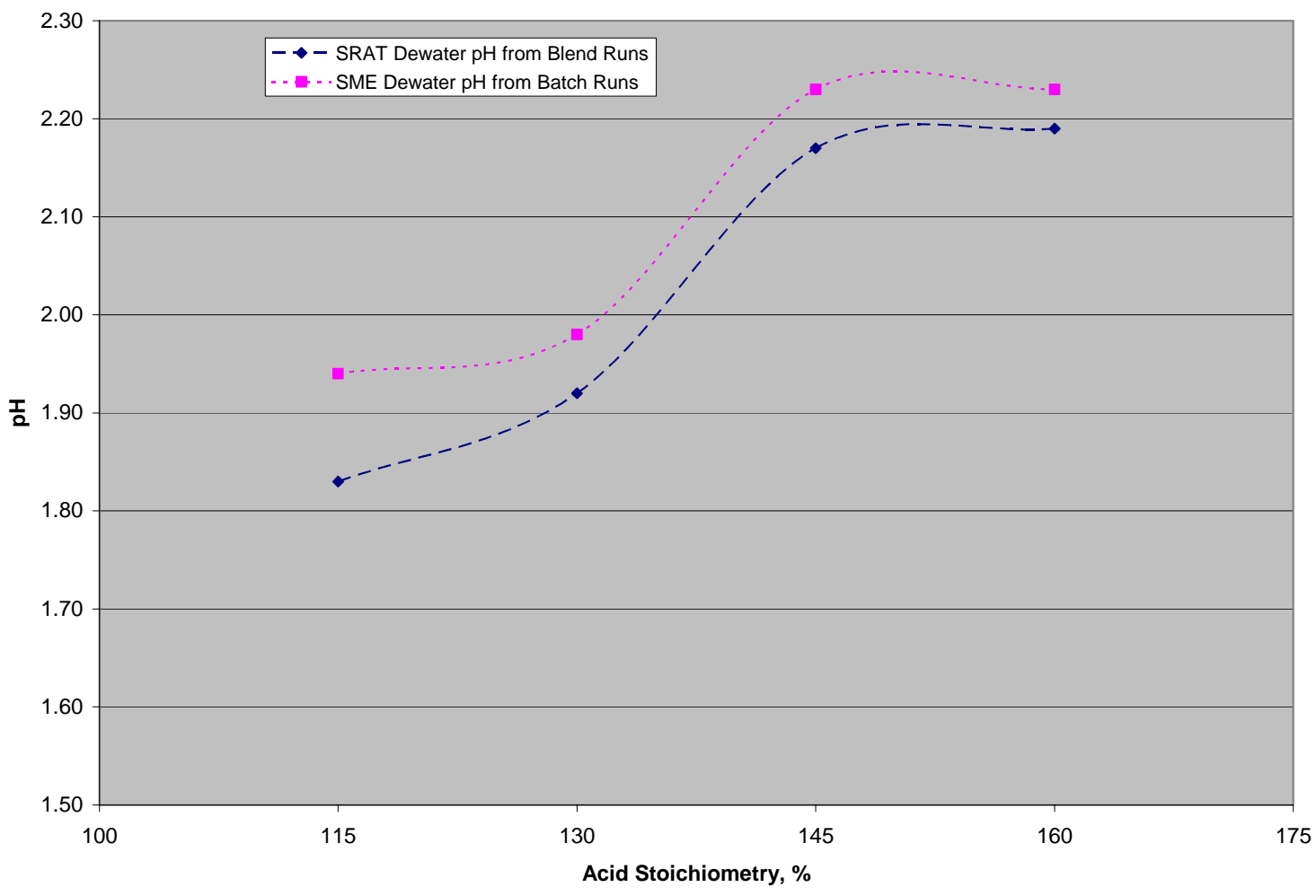

Figure 3. SRAT Dewater pH 


\subsubsection{SRAT Cycle Offgas Composition Results}

A typical offgas concentration profile is shown in Figure 4 while charts from all runs are shown in Appendix C. Helium and nitrogen show reduced concentrations during periods with large quantities of offgas generation due to dilution, while oxygen showed reduced concentrations during these periods due to dilution and from consumption. In general, hydrogen generation began after nitrous oxide emissions had ceased and carbon dioxide emission was noted in conjunction with the hydrogen. The patterns of offgas emissions noted during the runs were typical of offgas generation during the SRAT cycle.

\subsubsection{Hydrogen Evolution}

The peak hydrogen generation for each run is shown in Figure 5, along with the peak carbon dioxide and nitrous oxide rates. In general, the peak hydrogen generation rate increased with increased acid addition. None of the rates exceeded the SRAT processing limits of $0.65 \mathrm{lb} / \mathrm{hr}$, as shown in Table 12 which shows the peak hydrogen generation after scaling to the DWPF process.

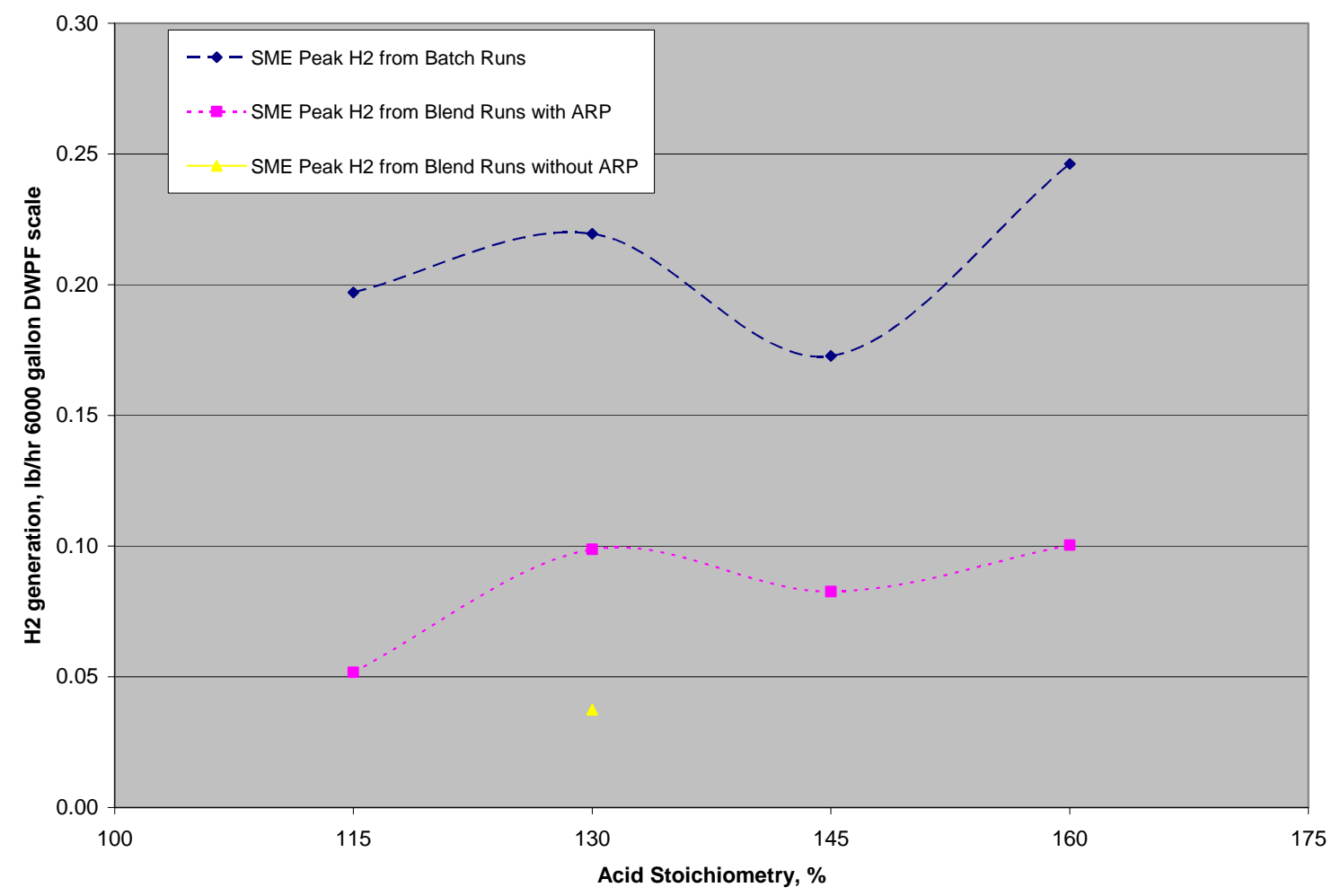

Figure 4. SRAT Cycle Hydrogen Peaks 
Table 12. SRAT Cycle Hydrogen Peak Generation Rate

\begin{tabular}{|l|l|c|c|c|c|c|}
\hline SRAT Hydrogen Peak & & \multicolumn{5}{|c|}{ Acid Stoichiometry } \\
\hline & & $115 \%$ & $130 \%$ & $\begin{array}{c}130 \% \\
\text { ARP/MCU }\end{array}$ & $145 \%$ & $160 \%$ \\
\hline SB5-C Simulant & $\mathrm{lb} / \mathrm{hr}$ & 0.0476 & 0.126 & - & 0.140 & 0.170 \\
\hline SB5-D Simulant & $\mathrm{lb} / \mathrm{hr}$ & 0.301 & 0.261 & 0.0655 & 0.366 & 0.569 \\
\hline
\end{tabular}

The hydrogen evolution as a function of time is shown in Figure 5.

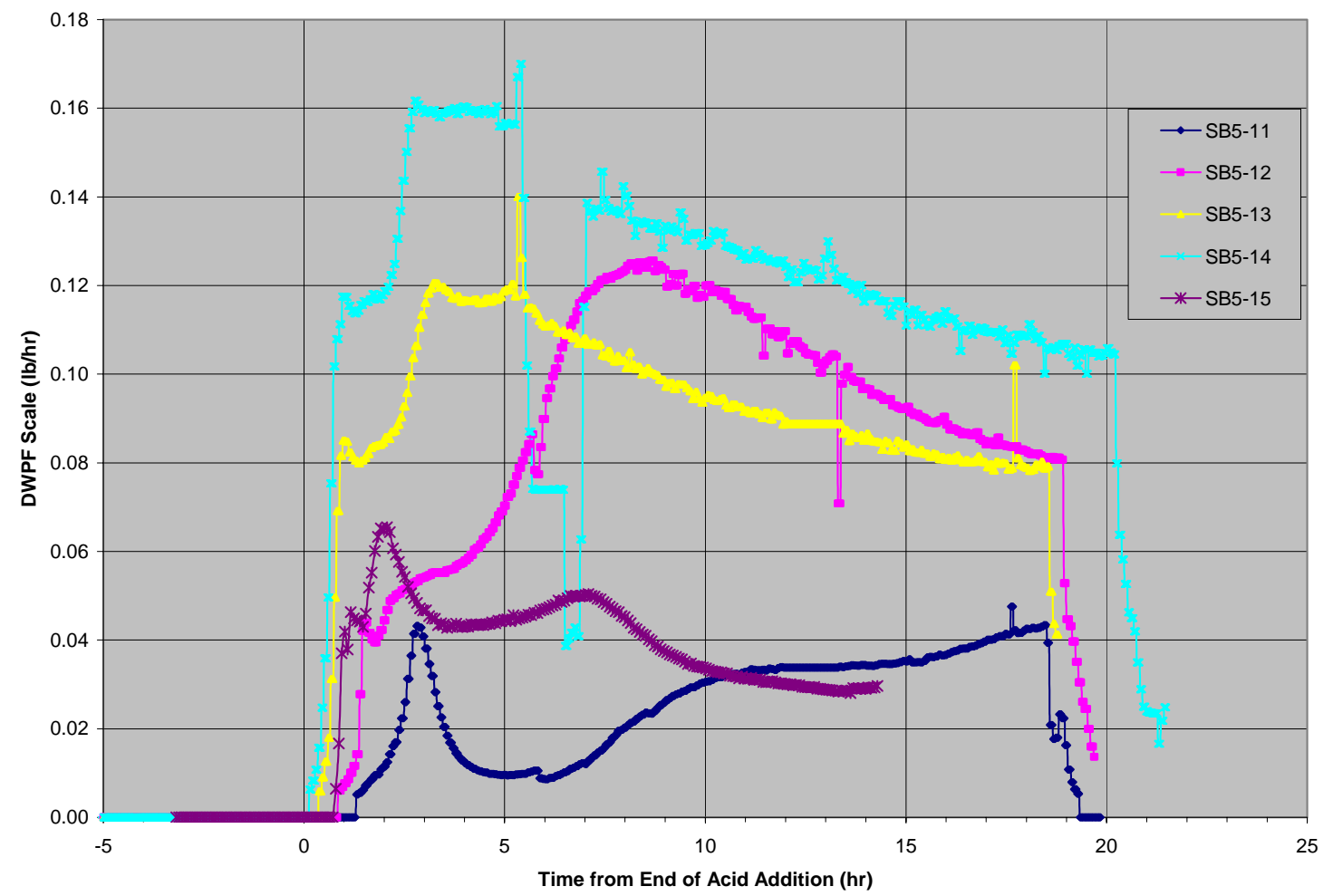

Figure 5c. SRAT Cycle Hydrogen Evolution from Tests with Blend Sludge SB5-C 


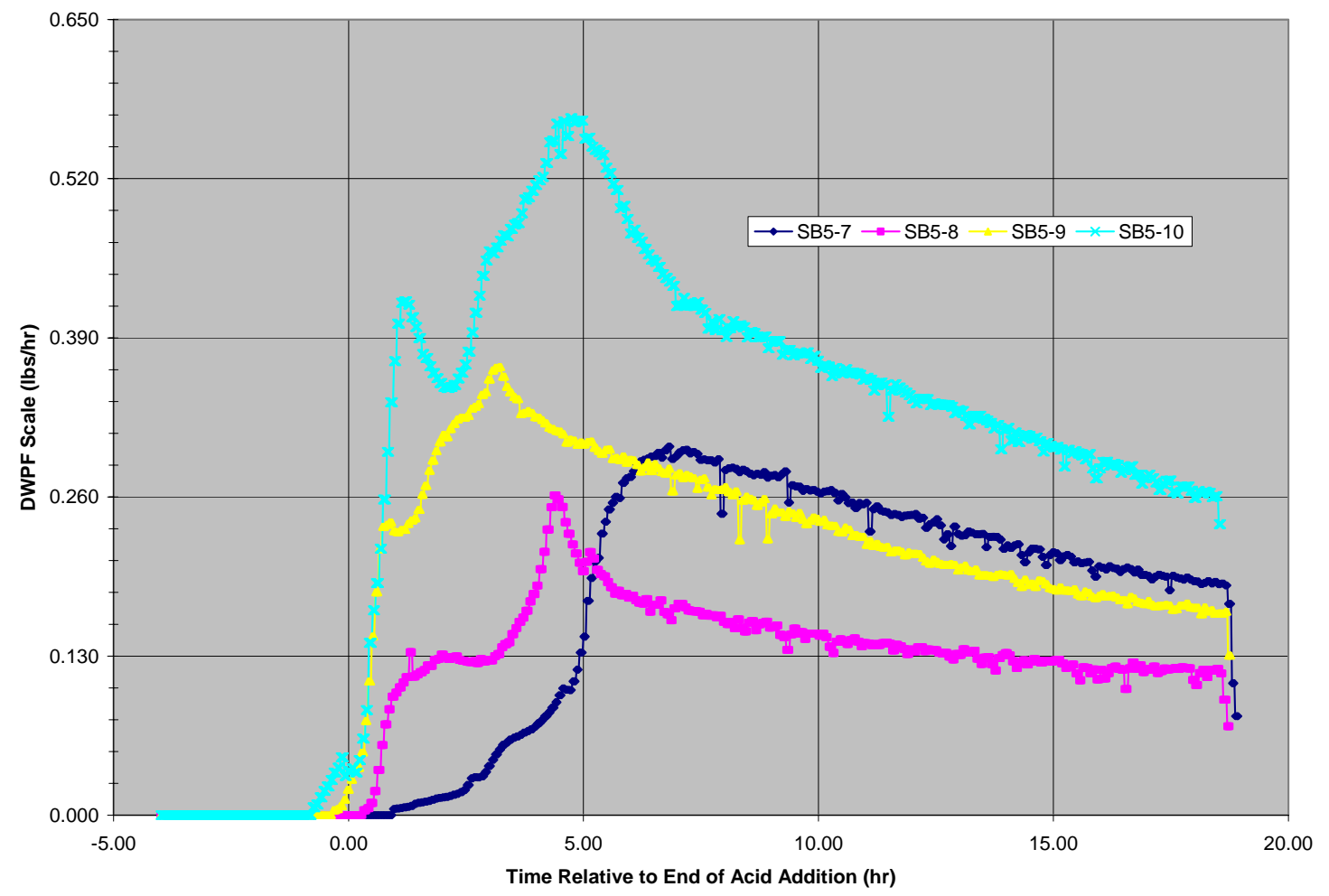

Figure 5d. SRAT Cycle Hydrogen Evolution from Tests with Batch Sludge SB5-D

\subsubsection{Other Species}

The nitrous oxide peak concentrations may have slightly increased as acid addition was increased. The carbon dioxide peak was very similar for all runs. The peak generation of these species is less dependent on acid concentration than hydrogen since more acid is added than needed to destroy carbonate and nitrite, the compounds that are responsible for the highest emissions. The peak generation rates are shown in Table $13 \mathrm{c}$ and $\mathrm{d}$ after scaling to the DWPF process scale.

Table 13c. SRAT Cycle Nitrous Oxide and Carbon Dioxide Peak Generation Rates from Tests with Blend Sludge SB5-C

\begin{tabular}{|l|l|c|c|c|c|c||}
\hline \multicolumn{2}{|c|}{} & \multicolumn{5}{|c|}{ Acid Stoichiometry } \\
\cline { 3 - 7 } \multicolumn{2}{|c|}{} & $\mathbf{1 1 5 \%}$ & $\mathbf{1 3 0 \%}$ & $\begin{array}{c}\mathbf{1 3 0 \%} \\
\mathbf{A R P}\end{array}$ & $\mathbf{1 4 5 \%}$ & $\mathbf{1 6 0 \%}$ \\
\hline SRAT Nitrous Oxide Peak & $\mathrm{lb} / \mathrm{hr}$ & 21.3 & 42.1 & 42.1 & 43.0 & 45.0 \\
\hline SRAT Carbon Dioxide Peak & $\mathrm{lb} / \mathrm{hr}$ & 486 & 489 & 508 & 483 & 471 \\
\hline
\end{tabular}

SB5-15 contained more TIC (from the ARP component). TIC destruction was the source of the maximum SRAT carbon dioxide peak in these runs. 
Table 13d. SRAT Cycle Nitrous Oxide and Carbon Dioxide Peak Generation Rates from Tests with Batch Sludge SB5-D

\begin{tabular}{||l|c|c|c|c|c||}
\hline \multicolumn{2}{|c|}{} & \multicolumn{4}{|c||}{ Acid Stoichiometry } \\
\cline { 3 - 6 } \multicolumn{2}{||c|}{} & $\mathbf{1 1 5 \%}$ & $\mathbf{1 3 0 \%}$ & $\mathbf{1 4 5 \%}$ & $\mathbf{1 6 0 \%}$ \\
\hline SRAT Nitrous Oxide Peak & $\mathrm{lb} / \mathrm{hr}$ & 45.7 & 45.2 & 54.9 & 51.6 \\
\hline SRAT Carbon Dioxide Peak & $\mathrm{lb} / \mathrm{hr}$ & 560 & 605 & 604 & 578 \\
\hline
\end{tabular}

\subsubsection{SRAT Product Rheological Properties}

The rheological properties of SRAT products were measured for the four runs produced with the batch simulant (SB5-D) along with the product from SB5-15 (blend simulant plus ARP/MCU). The rheological properties were outside the processing limits for yield stress and consistency for SRAT products (yield stress 1.5 to $5 \mathrm{~Pa}$ and Consistency 5 to $12 \mathrm{cP}$ ) ${ }^{\mathrm{d}}$ except for the $115 \%$ acid run. The yield stress and consistency of the SRAT products are shown in Table 14. The flow curves generated during the testing are shown in Appendix D.

Table 14. SRAT Product Rheological Properties

\begin{tabular}{||c|c|c|c|c|c||}
\hline Run & Acid \% & Yield Stress, Pa & Consistency, cP & Insoluble Solids, wt \% & Total Solids, wt \% \\
\hline SB5-7 & 115 & 3.6 & 8.3 & 13.84 & 25.64 \\
\hline SB5-8 & 130 & 0.5 & 4.2 & 12.28 & 24.01 \\
\hline SB5-9 & 145 & 0.3 & 3.6 & 13.47 & 23.96 \\
\hline SB5-10 & 160 & 0.1 & 2.2 & 14.84 & 24.17 \\
\hline SB5-15 & 130 & 1.1 & 8.2 & 11.53 & 24.46 \\
\hline \hline
\end{tabular}

\subsubsection{Impact of ARP/MCU on SRAT Processing}

The addition of ARP and MCU did not cause any other processing issues, since foaming, rheology and hydrogen generation were less of an issue while processing ARP/MCU. Hydrogen was significantly lower in Run SB5-15 (with added ARP/MCU) compared to Run SB5-12 (no added ARP/MCU), a similar run with the same $130 \%$ acid stoichiometry.

Adding ARP or MCU will extend processing times in DWPF. The ARP caustic boil took approximately six hours. The boiling time during the experiment with added MCU was 14 hours at the maximum DWPF steam flux rate. This is slightly longer than typical DWPF processing and will take even longer if boilup rates are lower than the maximum steam flux.

\footnotetext{
d “Technical Data Summary for the Defense Waste Processing Facility: Sludge Plant”, DPSTD-80-38-2
} 


\subsection{SME Cycle Results}

The SME cycle was performed immediately following the SRAT cycle and utilized the estimated amount of frit based on the initial sludge additions and the expected amount of SRAT samples. The SME cycles for Runs SB5-7, 8,9 and 10 included the addition of water simulating five decon water additions along with two frit slurry additions, whereas the SME cycles for Runs SB5-11, 12, 13 and 14 included only the two frit water slurry additions. These latter runs were approximately 12 hours shorter. This decision was conservative from hydrogen generation but also shortens the time for the SME cycles. As stated earlier, the SME cycle targeted a final solids concentration of $45 \mathrm{wt} \%$ total solids based on earlier testing with SB4 that resulted in extremely viscous slurries at the end of the SME cycle ${ }^{16}$.

\subsubsection{Processing Observations}

Only hydrogen generation was noted as a potential processing issue during the SME cycle. The hydrogen for the batch simulant was significantly higher than for the blend simulant. Mixing was not an issue during processing. Mixer speed was maintained at 250 RPM throughout each run.

As shown in Figure 6c and d, the pH profile of each SME cycle followed a similar profile with a dip in $\mathrm{pH}$ as the frit is added due to the formic acid content of the frit slurry followed by a gradual rise in $\mathrm{pH}$ as the slurry mix is evaporated.

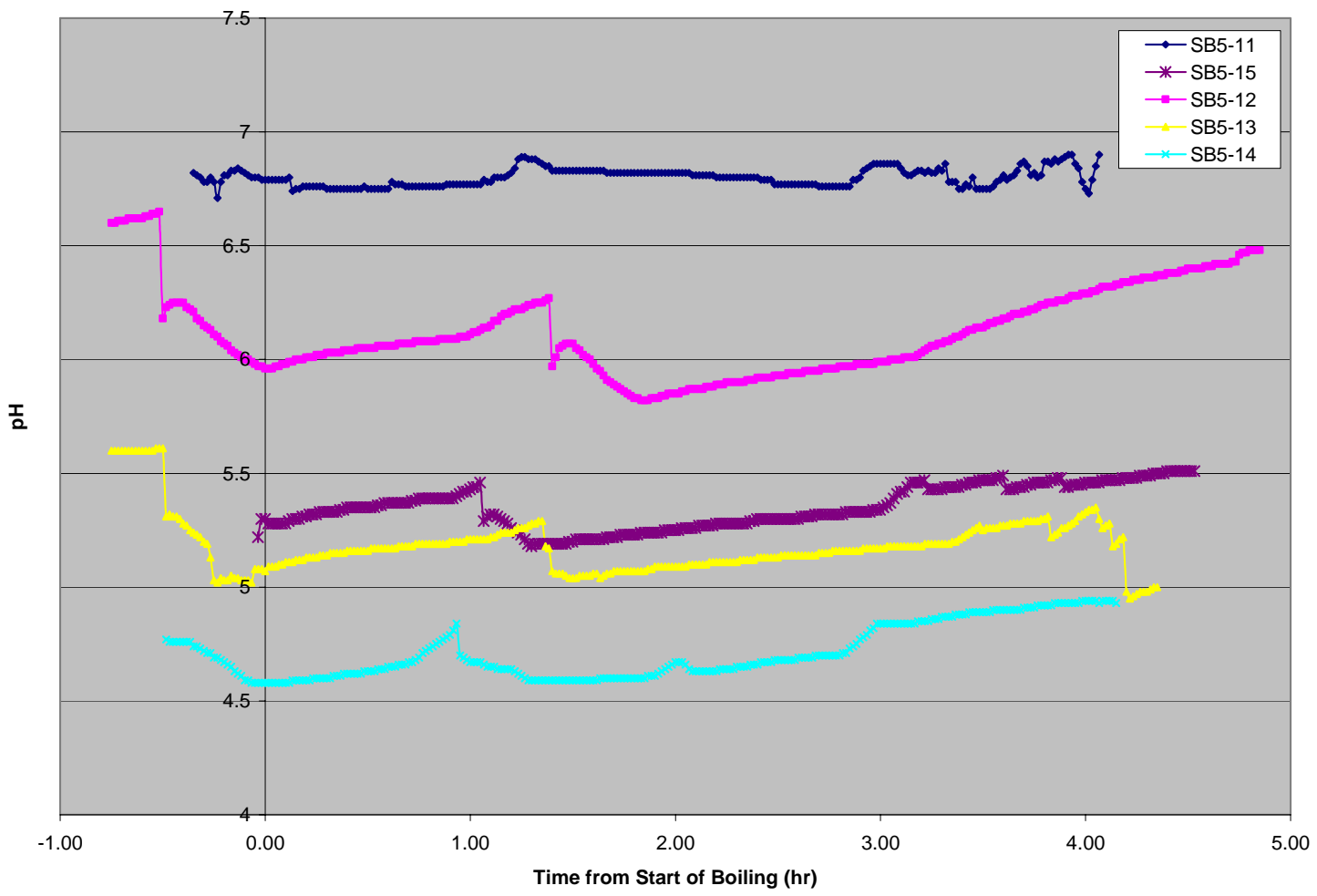

Figure 6c. SME pH Profile from Tests with Blend Sludge SB5-C 


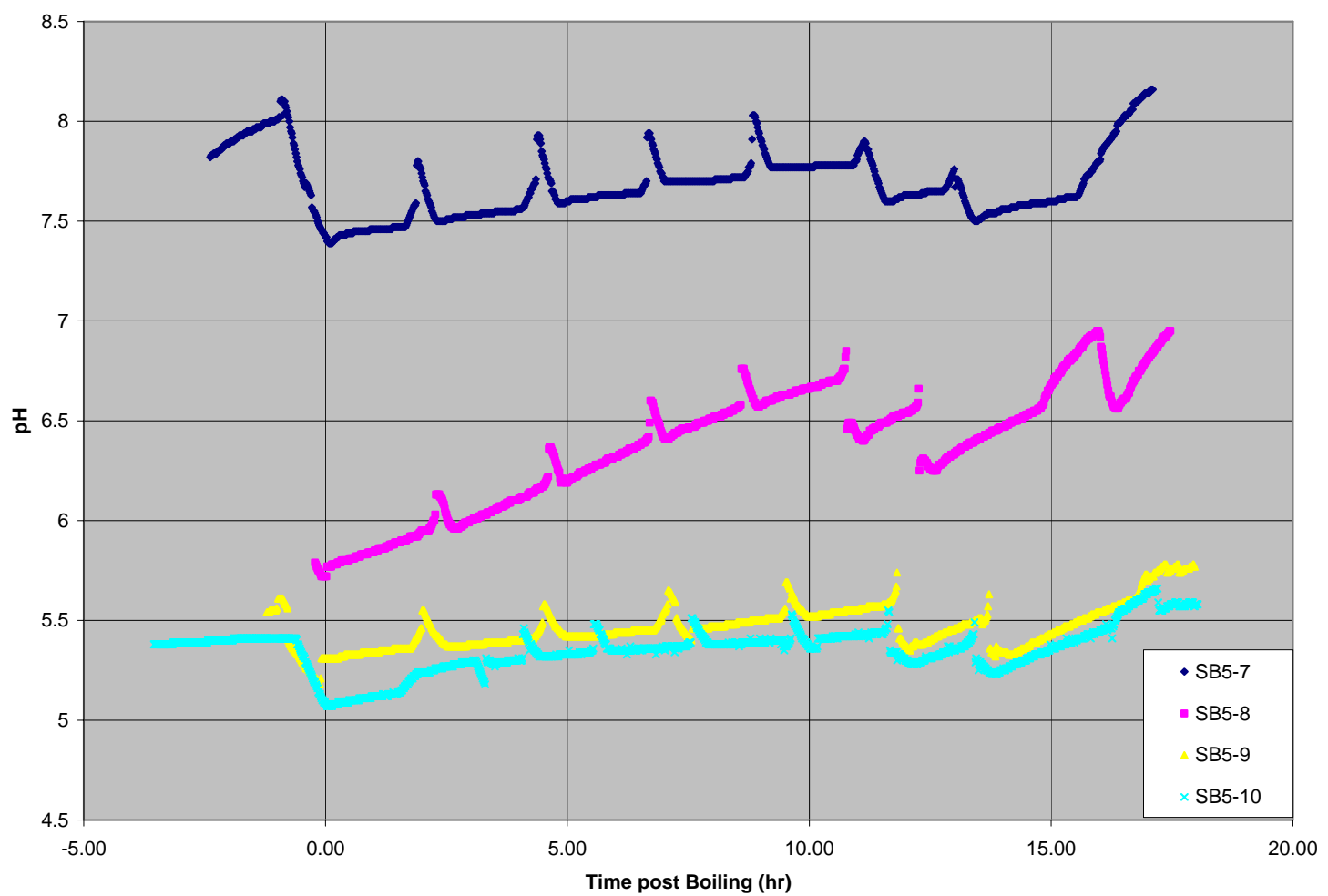

Figure 6d. SME pH Profile from Tests with Batch Sludge SB5-D

\subsubsection{SME Cycle Sample Results}

Samples were pulled at the conclusion of the SME cycle and analyzed for total solids, anions, soluble elemental species, mercury, and REDOX. Samples were taken of the SME dewater and the FAVC contents at the completion of the SME cycle.

\subsubsection{SME Product Results}

The solids content of the SME products are shown in Table 15c and Table 15d along with the calculated waste loading and $\mathrm{pH}$. The solids content generally were higher than targeted, but the waste loading targets were all $>40 \%$, significantly higher than the $35 \%$ target. Waste loadings were calculated from the lithium content of the SME product (the frit 418 was $7.42 \% \mathrm{Li}$ ).

Table 15c. SME Product Results from Tests with Blend Sludge SB5-C

\begin{tabular}{||c|c|c|c|c||}
\hline \hline Acid \% & pH & $\begin{array}{c}\text { TOTAL } \\
\text { SOLIDS }\end{array}$ & $\begin{array}{c}\text { LITHIUM OXIDE } \\
\text { CONTENT }\end{array}$ & $\begin{array}{c}\text { WASTE } \\
\text { LOADING }\end{array}$ \\
\hline $115 \%$ & & wt $\%$ & wt \% Calcined solids & Wt \% \\
\hline $130 \%$ & 6.80 & 47.7 & 4.64 & 37.4 \\
\hline $130 \%$ ARP/MCU & 4.82 & 45.7 & 4.80 & 35.2 \\
\hline $145 \%$ & 4.71 & 43.7 & 4.52 & 39.1 \\
\hline $160 \%$ & 4.41 & 47.2 & 4.67 & 37.1 \\
\hline
\end{tabular}

\footnotetext{
e $\%$ Waste Loading $=(1$-Lithium in SME product $/ 8) * 100 \%$
} 
Table 15d. SME Product Results from Tests with Batch Sludge SB5-D

\begin{tabular}{||c|c|c|c|c||}
\hline \hline Acid \% & $\mathbf{p H}$ & $\begin{array}{c}\text { TOTAL } \\
\text { SOLIDS } \\
\text { Wt\% }\end{array}$ & $\begin{array}{c}\text { LITHIUM OXIDE } \\
\text { CONTENT, } \\
\text { Wt \% Calcined } \\
\text { Solids }\end{array}$ & $\begin{array}{c}\text { WASTE } \\
\text { LOADING, } \\
\text { Wt \% }\end{array}$ \\
\hline $115 \%$ & 8.26 & 46.6 & 4.77 & 35.7 \\
\hline $130 \%$ & 7.22 & 45.0 & 4.80 & 35.3 \\
\hline $145 \%$ & 5.71 & 44.5 & 4.80 & 35.3 \\
\hline $160 \%$ & 5.46 & 44.6 & 4.68 & 36.9 \\
\hline
\end{tabular}

Loss of formate varied considerably during the SME cycles, as shown in Table 16c and Table 16d. The range of values noted during the testing are similar to results from previous runs 4 . The amount of nitrate loss was high for most runs, with the lowest acid stoichiometry indicating a loss of $27 \%$. The high losses at $115 \%$ acid and the negative value for the $130 \%$ acid likely resulted from the expected analytical error and cumulative errors in the mass balance as various samples are pulled.

Table 16c. SME Product Anion Conversions from Tests with Blend Sludge SB5-C

\begin{tabular}{||c||c|c||}
\hline \hline \multirow{2}{*}{$\begin{array}{c}\text { Acid } \\
\text { Stoichiometry }\end{array}$} & \multicolumn{2}{c||}{ SME CYCLE } \\
\cline { 2 - 3 } & $\begin{array}{c}\text { Formate } \\
\text { Destruction }\end{array}$ & $\begin{array}{c}\text { Nitrate } \\
\text { Destruction }\end{array}$ \\
\hline $115 \%$ & $5 \%$ & $4 \%$ \\
\hline $130 \%$ & $6 \%$ & $-3 \%$ \\
\hline $130-A R P / M C U$ & $11 \%$ & $11 \%$ \\
\hline $160 \%$ & $3 \%$ & $4 \%$ \\
\hline $160 \%$ & $28 \%$ & $21 \%$ \\
\hline
\end{tabular}

Table 16d. SME Product Anion Conversions from Tests with Batch Sludge SB5-D

\begin{tabular}{|c|c|c|}
\hline \multirow{2}{*}{$\begin{array}{c}\text { Acid } \\
\text { Stoichiometry }\end{array}$} & \multicolumn{2}{|c|}{ SME CYCLE } \\
\hline & $\begin{array}{c}\text { Formate } \\
\text { Destruction }\end{array}$ & $\begin{array}{c}\text { Nitrate } \\
\text { Destruction }\end{array}$ \\
\hline $115 \%$ & $27 \%$ & $27 \%$ \\
\hline $130 \%$ & $7 \%$ & $6 \%$ \\
\hline $145 \%$ & $11 \%$ & $13 \%$ \\
\hline $160 \%$ & $15 \%$ & $11 \%$ \\
\hline
\end{tabular}

\subsubsection{Condensates}

The condensate $\mathrm{pH}$ from SME dewater decreased as acid stoichiometry increased. $\mathrm{pH}$ was generally higher than the SRAT dewater and the SRAT MWWT. The $\mathrm{pH}$ was higher during runs with the lowest acid addition, as shown in Figure 7. 
SRNS-STI-2008-00024

Revision 0

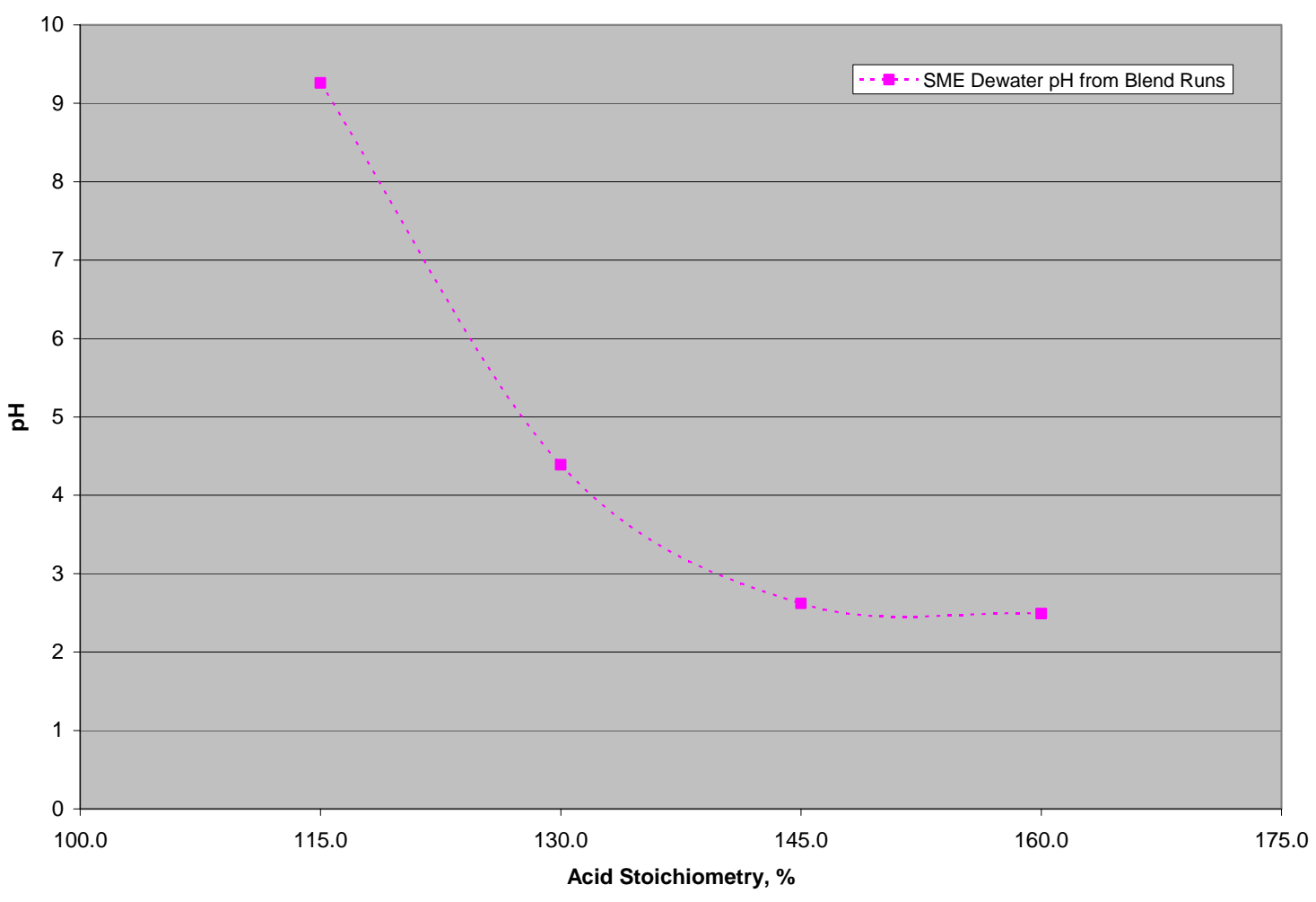

Figure 7. SME Dewater pH

\subsubsection{SME Cycle Offgas Composition Results}

The amount of offgas generated during the runs generally increased as acid stoichiometry increased, as indicated by the helium concentration in the offgas since helium is added at a constant $0.5 \mathrm{wt} \%$ of the incoming air purge. A typical offgas concentration profile is shown in Figure 8 while charts from all runs are shown in Appendix C. The patterns of offgas emissions noted during the runs were typical of offgas generation during the SME cycle with hydrogen and carbon dioxide emissions occurring during dewatering after each frit addition. 


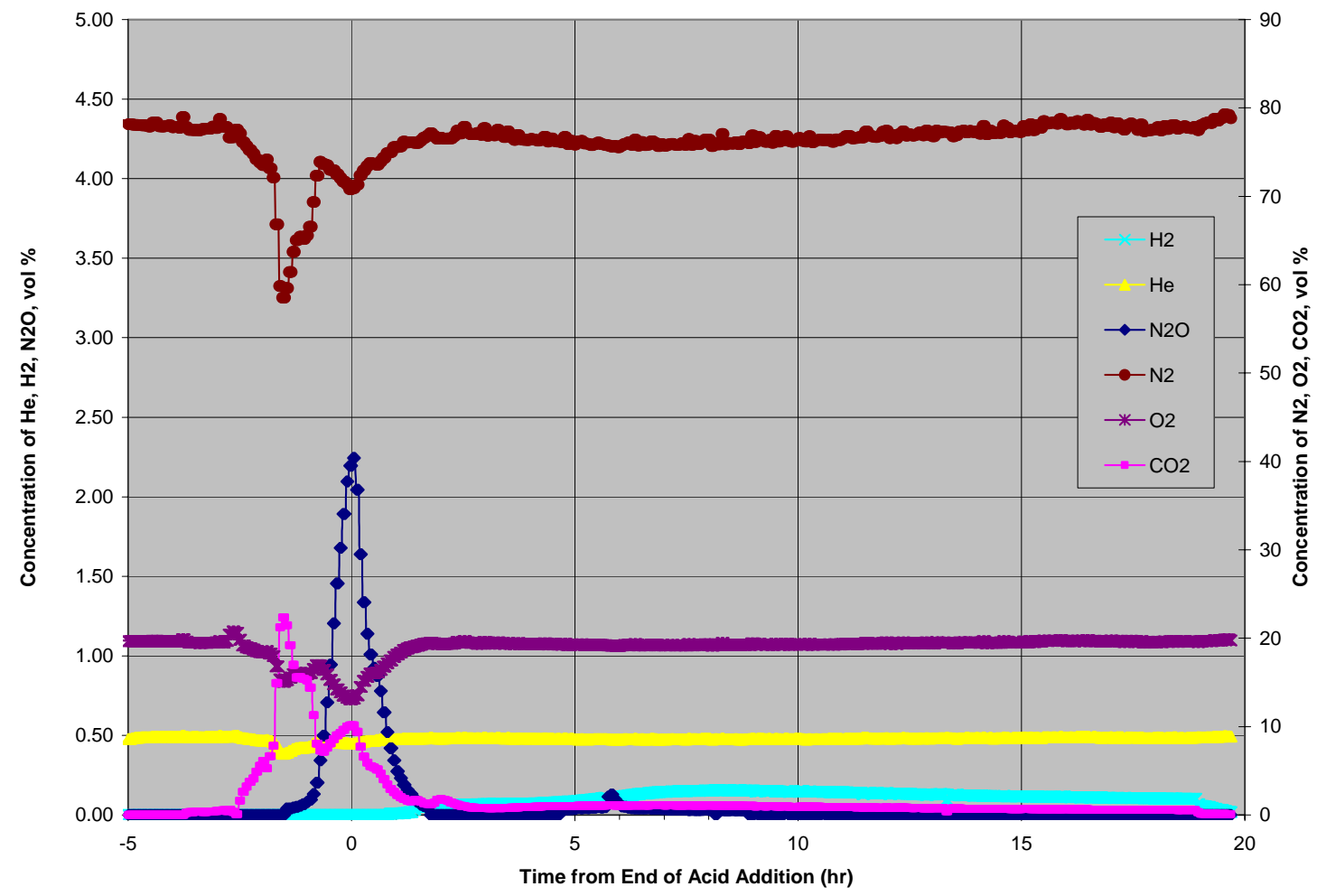

Figure 8. Typical Offgas Profile 130\% Acid Stoichiometry, Blend Simulant

\subsubsection{Hydrogen Evolution}

The peak hydrogen generation rates were generally noted as sharp spikes in the data immediately following the start of dewater, as shown in Figure 8 above. Hydrogen reached concentrations higher than noted in the SRAT cycle due to the decreased purge during the SME cycle. Peak hydrogen concentrations reached close to 0.5 volume \%, as shown in Figure 9 and were a function of acid stoichiometry. Peak generation rates scaled to the DWPF process are shown in Table 17 and were all below the SME process limit of $0.223 \mathrm{lb} / \mathrm{hr}$, except for the $160 \%$ stoichiometry. 


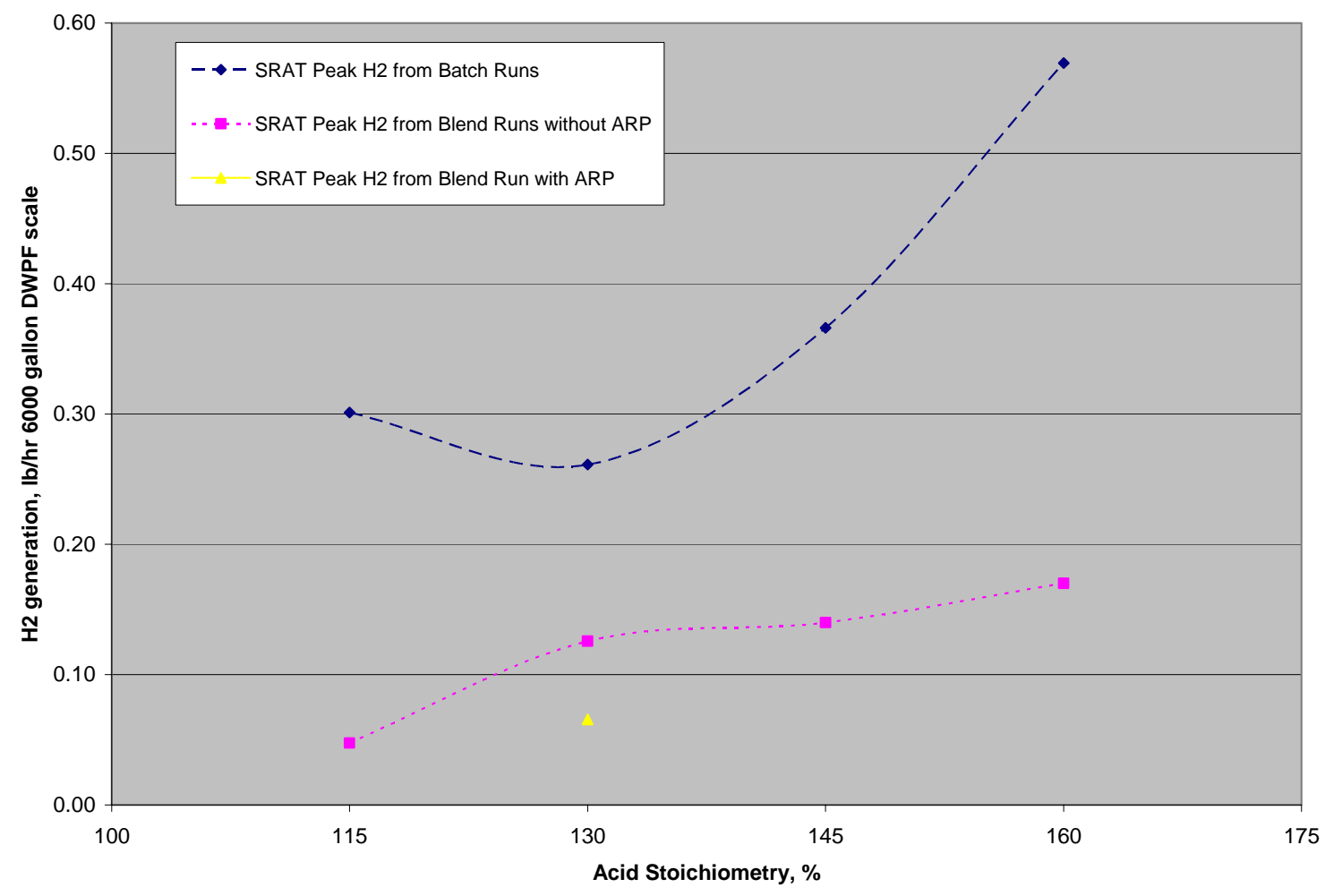

Figure 9. Peak Hydrogen Generation during SME Cycle

Table 17. SME Cycle Hydrogen Peak Generation Rate

\begin{tabular}{|c|c|c|c|c|c|c|}
\hline \multirow{2}{*}{\multicolumn{2}{|c|}{ SME Hydrogen Peak }} & \multirow{2}{*}{\multicolumn{5}{|c|}{ Acid Stoichiometry }} \\
\hline & & & & & & \\
\hline SB5-C Simulant & $\mathrm{lb} / \mathrm{hr}$ & 0.0517 & 0.0987 & 0.116 & 0.0826 & 0.100 \\
\hline SB5-D Simulant & $\mathrm{lb} / \mathrm{hr}$ & 0.197 & 0.220 & - & 0.173 & 0.246 \\
\hline
\end{tabular}

\subsubsection{Other Species}

Carbon dioxide was generally the only other gas of any significance emitted during the SME cycle (the higher acid runs contained a small amount of nitrous oxide emissions).

Table 18c. SME Cycle Nitrous Oxide and Carbon Dioxide Peak Generation Rates from Tests with Blend Sludge SB5-C

\begin{tabular}{|l|l|c|c|c|c|c||}
\hline \multicolumn{2}{|c|}{} & \multicolumn{5}{|c|}{ Acid Stoichiometry } \\
\cline { 3 - 7 } & $\mathbf{1 1 5 \%}$ & $\mathbf{1 3 0 \%}$ & $\begin{array}{c}\mathbf{1 3 0 \%} \\
\text { ARP }\end{array}$ & $\mathbf{1 4 5 \%}$ & $\mathbf{1 6 0 \%}$ \\
\hline SRAT Nitrous Oxide Peak & $\mathrm{lb} / \mathrm{hr}$ & 0.00 & 0.00 & 0.00 & 0.000 & 0.00 \\
\hline SRAT Carbon Dioxide Peak & $\mathrm{lb} / \mathrm{hr}$ & 23.5 & 28.8 & 30.8 & 20.6 & 15.7 \\
\hline
\end{tabular}


Table 18d. SME Cycle Nitrous Oxide and Carbon Dioxide Peak Generation Rates from Tests with Batch Sludge SB5-D

\begin{tabular}{||l|c|c|c|c|c||}
\hline \hline \multicolumn{2}{|c|}{} & \multicolumn{4}{|c||}{ Acid Stoichiometry } \\
\cline { 3 - 6 } \multicolumn{2}{||c|}{} & $\mathbf{1 1 5 \%}$ & $\mathbf{1 3 0 \%}$ & $\mathbf{1 4 5 \%}$ & $\mathbf{1 6 0 \%}$ \\
\hline SME Nitrous Oxide Peak & $\mathrm{lb} / \mathrm{hr}$ & 0.00 & 1.70 & 1.59 & 1.35 \\
\hline SME Carbon Dioxide Peak & $\mathrm{lb} / \mathrm{hr}$ & 38.9 & 47.8 & 29.8 & 31.0 \\
\hline
\end{tabular}

\subsubsection{SME Product Rheological Properties}

The rheological properties of each SME product with batch simulant were measured along with those of the blend simulant run with ARP/MCU. Higher acid stoichiometry lowered the yield stress and consistency of the SME products. The 115\% acid run exceeded the upper process limit for yield stress $(15 \mathrm{~Pa})^{\mathrm{f}}$ and consistency $(10$ to $40 \mathrm{cP})$. The two highest acid runs exceeded the process limits for yield stress $(2.5 \mathrm{~Pa})$, as shown in Table 19 .

Table 19. SME Product Rheological Properties from Tests with Batch Sludge SB5-D

\begin{tabular}{||c|c|c|c|c||}
\hline \hline Run & Acid \% & Yield Stress, Pa & Consistency, cP & Total Solids, wt \% \\
\hline SB5-7 & 115 & 23.8 & 49.8 & 46.6 \\
\hline SB5-8 & 130 & 3.1 & 16.0 & 44.95 \\
\hline SB5-15 & 130 & 2.1 & 24.8 & 46.2 \\
\hline SB5-9 & 145 & 1.8 & 11.5 & 44.5 \\
\hline SB5-10 & 160 & 1.6 & 10.9 & 44.6 \\
\hline \hline
\end{tabular}

\subsubsection{REDOX Results}

The predicted REDOX values shown in Table 20 are based on the sample results of the SME product. Measured values are the average of duplicate samples generated by the guidelines of L29 ITS-0052 "Vitrification of Melter Slurries for Glass Redox $\left(\mathrm{Fe}^{2+} / \Sigma \mathrm{Fe}\right)$ \& Chemical Composition Measurement"17.

Table 20. SME Product REDOX from Blend Runs (SB5-11 to SB5-14)

\begin{tabular}{|c|c|c|c|}
\hline Run & $\begin{array}{l}\frac{\text { REDOX }}{\text { Result }_{1}} \\
\text { Fe }^{+2} \mid \Sigma \mathrm{Fe} \\
\end{array}$ & 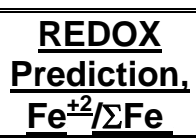 & $\begin{array}{c}\frac{\text { Acid }}{\text { Stoichiometry }} \\
\underline{\%}\end{array}$ \\
\hline SB5-11 & 0.23 & 0.244 & 115 \\
\hline SB5-12 & 0.25 & 0.21 & 130 \\
\hline SB5-13 & 0.22 & 0.22 & 145 \\
\hline SB5-14 & 0.26 & 0.229 & 160 \\
\hline
\end{tabular}

\footnotetext{
f “Technical Data Summary for the Defense Waste Processing Facility: Sludge Plant”, DPSTD-80-38-2
} 
As shown in Figure 10, the measured REDOX increased with increased acid stoichiometry. Although most of the REDOX measurements were greater than predicted, there was a fairly close correlation between the prediction and result. More information on the SB5 REDOX results is summarized in a separate SRNL memo ${ }^{18}$.

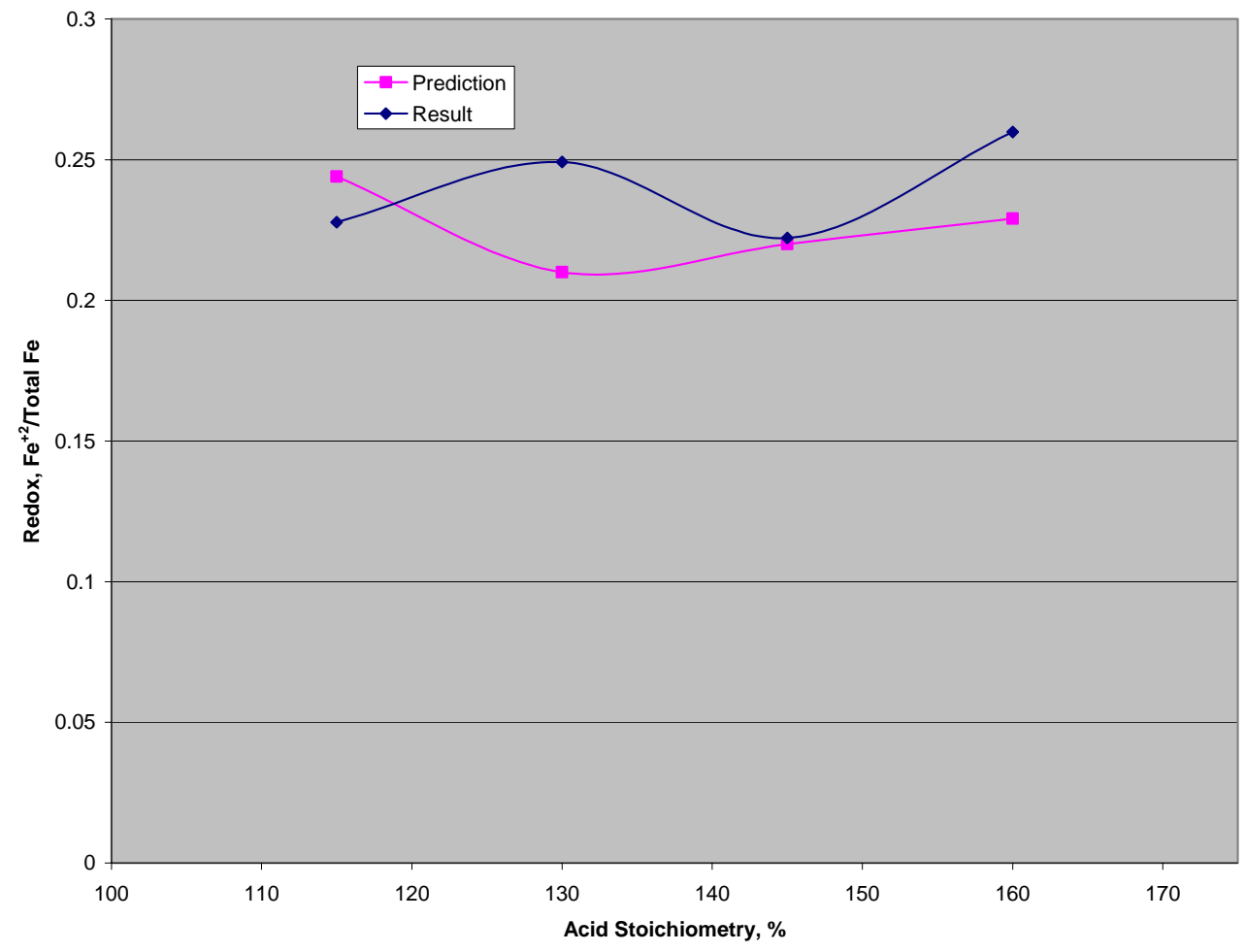

Figure 10. SB5 Flowsheet Testing REDOX Results 


\subsection{Conclusions}

Two SB5 processing issues were noted during testing. First, high hydrogen generation rates were measured during experiments with both the blend and batch simulant at high acid stoichiometry. Also, the reflux time was extended due to the high mercury concentration in both the batch and blend simulant.

Adding ARP will extend processing times in DWPF. The ARP caustic boil took approximately six hours. The boiling time during the experiment with added MCU was 14 hours at the maximum DWPF steam flux rate. This is comparable to the combined dewatering and reflux time for a nominal SRAT batch using $5000 \mathrm{lbs} / \mathrm{hr}$ boil-up rates during boiling, but would require considerably more time at $2000-2500 \mathrm{lbs} / \mathrm{hr}$ boil-up rates. The addition of ARP and MCU did not cause any other processing issues, as foaming, rheology and hydrogen generation were less of an issue while processing ARP/MCU.

\section{Hydrogen and nitrous oxide generation rates as a function of acid stoichiometry}

Hydrogen generation was significantly impacted by the changes in acid stoichiometry from $115 \%$ to $160 \%$ (1.96 to 2.73 moles acid per liter of batch sludge or 1.28 to 1.79 moles acid per liter of blend sludge). For the batch sludge, the hydrogen generation rate exceeded the process limit during the SME cycle at the highest acid stoichiometry (160\%). All of the blend experiments were within the process limits throughout the SRAT and SME cycles. As DWPF will be processing blend sludge, hydrogen likely won't be an issue in DWPF processing but lower acid stoichiometries will minimize hydrogen generation. The reduction in $\mathrm{Hg}$ concentration of the SRAT receipt slurry after combining ARP with sludge and concentrating it to the same wt $\%$ total solids led to increased hydrogen generation rates at $130 \%$ stoichiometry compared to the run without ARP. The nitrous oxide generation peak was relatively insensitive to acid stoichiometry and was relatively low due to the low starting nitrite concentration. Hydrogen generation and nitrous oxide generation scaled to DWPF are shown in Table 21c and Table 21d.

Table 21c. Offgas Peak Summary Blend

\begin{tabular}{||l|c|c|c|c|c||}
\hline \hline \multicolumn{2}{|c|}{} & \multicolumn{4}{c||}{ Acid Stoichiometry } \\
\cline { 3 - 6 } & & $115 \%$ & $130 \%$ & $145 \%$ & $160 \%$ \\
\hline SRAT Hydrogen Peak & $\mathrm{lb} / \mathrm{hr}$ & 0.0476 & 0.126 & 0.140 & 0.170 \\
\hline SME Hydrogen Peak & $\mathrm{lb} / \mathrm{hr}$ & 0.0517 & 0.0987 & 0.0826 & 0.100 \\
\hline SRAT Nitrous Oxide Peak & $\mathrm{lb} / \mathrm{hr}$ & 21.3 & 42.1 & 43.0 & 45.0 \\
\hline SME Nitrous Oxide Peak & $\mathrm{lb} / \mathrm{hr}$ & 0.0000 & 0.0000 & 0.173 & 0.0000 \\
\hline SRAT Carbon Dioxide Peak & $\mathrm{lb} / \mathrm{hr}$ & 486 & 489 & 483 & 471 \\
\hline SME Carbon Dioxide Peak & $\mathrm{lb} / \mathrm{hr}$ & 23.5 & 28.8 & 20.6 & 15.7 \\
\hline
\end{tabular}

Table 21d. Offgas Peak Summary Batch

\begin{tabular}{||l|c|c|c|c|c||}
\hline \multirow{2}{*}{\multicolumn{2}{|c|}{}} & \multicolumn{4}{|c||}{ Acid Stoichiometry } \\
\cline { 3 - 6 } & & $115 \%$ & $130 \%$ & $145 \%$ & $160 \%$ \\
\hline SRAT Hydrogen Peak & $\mathrm{lb} / \mathrm{hr}$ & 0.301 & 0.261 & 0.366 & 0.569 \\
\hline SME Hydrogen Peak & $\mathrm{lb} / \mathrm{hr}$ & 0.197 & 0.220 & 0.173 & 0.246 \\
\hline SRAT Nitrous Oxide Peak & $\mathrm{lb} / \mathrm{hr}$ & 45.7 & 45.2 & 54.9 & 51.6 \\
\hline SME Nitrous Oxide Peak & $\mathrm{lb} / \mathrm{hr}$ & 0.00 & 1.70 & 1.59 & 1.35 \\
\hline SRAT Carbon Dioxide Peak & $\mathrm{lb} / \mathrm{hr}$ & 560 & 605 & 604 & 578 \\
\hline SME Carbon Dioxide Peak & $\mathrm{lb} / \mathrm{hr}$ & 38.9 & 47.8 & 29.8 & 31.0 \\
\hline
\end{tabular}


Acid quantities and processing times required for mercury removal

Mercury was added to the sludge simulant at the start of the SRAT cycle as mercuric oxide at approximately $2.5 \mathrm{wt} \%$ (solids basis) based on the expected composition of the SB5 batch and blend. Because of the high mercury concentration, the time at boiling was increased from 12 hours to 18 hours to allow sufficient time to strip mercury from the SRAT. Boiling flux was maintained at a scaled rate of $5,000 \mathrm{lb} / \mathrm{hr}$ so a total of $90,000 \mathrm{lb}$ of steam flow in DWPF will be needed to remove $120 \mathrm{lb}$ of mercury. Acid quantities from $115 \%$ to $160 \%$ resulted in satisfactory mercury removal with 18 hours of boiling time, with the exception of the two lowest acid stoichiometry runs with the blend simulant. If DWPF experiences problems stripping mercury, increasing the acid stoichiometry is likely to improve mercury removal but also will increase hydrogen generation. Simulant testing does not simulate the DWPF heel so starting mercury concentrations will be lower in DWPF and shorter steam stripping times should be achievable.

\section{Acid quantities and processing times required for nitrite destruction}

Acid quantities from $115 \%$ to $160 \%$ resulted in satisfactory nitrite destruction with 18 hours of boiling. In all runs, the amount of nitrite present in the SRAT product was less than $100 \mathrm{mg} / \mathrm{kg}$, well below the $1,000 \mathrm{mg} / \mathrm{kg}$ target. The longer boiling time and low starting nitrite concentration both helped to reduce the nitrite by the end of the SRAT cycle.

D Impact of SB5 composition (in particular, manganese, nickel, mercury, and aluminum) on DWPF processing (i.e. acid addition strategy, foaming, hydrogen generation, REDOX control, rheology, etc.)

Acid quantities from $130 \%$ to $160 \%$ resulted in satisfactory process performance with no significant issues noted. Foaming was noted during formic acid addition, but the addition of antifoam equal to the amount added at DWPF was sufficient to control foaming.

Except for the $115 \%$ run, all SRAT products were outside the process limits for yield stress and consistency with the $130 \%, 145 \%$ and $160 \%$ runs being below the process limit. The process limits for SME product yield stress were met for the $130 \%$ acid run at $45 \%$ solids, but the $115 \%$ acid run was above process limits and the $145 \%$ and $160 \%$ runs were slightly below process limits. It should be noted that the trend seen in rheological properties of the simulants are expected to be similar for the DWPF process slurries, but the absolute values for the simulants are not expected to be prototypical in yield stress or consistency. Adjustment in the solids concentration targets and/or acid stoichiometry should be made if processing problems due to viscous process slurries are noted in DWPF.

The $\mathrm{pH}$ of the condensate generated for all eight SRAT cycles was acidic, but the $115 \%$ acid runs resulted in condensate that was basic by the end of the SRAT cycle and throughout the SME cycle with a $\mathrm{pH}$ of approximately 9 . All condensates from all other runs had a $\mathrm{pH}$ of less than 5.

Measured REDOX values for most runs were slightly higher than the predicted values for the batch simulant. REDOX values increased slightly as acid stoichiometry was increased. 


\subsection{Recommendations}

Based on these two sets of runs, an acid stoichiometry of $130 \%$ is recommended for initial SB5 processing with an acid window of $115 \%$ to $160 \%$. The SB5 batch simulant used during the testing had a stoichiometric acid requirement of $2.22 \mathrm{~mol} / \mathrm{L}$ at $130 \%$ acid, and the SB5 blend simulant had a stoichiometric acid requirement of $1.45 \mathrm{~mol} / \mathrm{L}$ at $130 \%$ acid. The actual DWPF recommendation will be finalized once SB5 shielded cells processing studies are completed.

Due to an expected high mercury concentration in the SB5 sludge (approximately $2.5 \mathrm{wt} \%$ ), the total mass of steam required for effective steam stripping should be set at 90,000 lb (18 hours times $5,000 \mathrm{lb} / \mathrm{hr}$ ). The boiling time can be shortened if better mercury stripping efficiency is experienced in DWPF. Increasing acid stoichiometry may lead to better mercury stripping based on simulant testing. 


\subsection{References}

1 Culbertson, B. H., Sludge Batch 5 Flowsheet Studies. HLW/DWPF/TTR-2007-0008 Revision 1, Savannah River Site, Aiken, SC 29808 (2006).

2 Lambert, D. P., Task Technical \& QA Plan: Sludge Batch 5 Simulant Flowsheet Studies, WSRC-RP-2006-01208 Revision 0, Savannah River Site, Aiken, SC 29808 (2007).

3 Baich, M.A., C.C. Herman, D.R. Best, M.F. Williams, and E.K. Hansen, Sludge Batch 4 Initial Simulant Flowsheet Studies: Phase I SRAT Results, WSRC-TR-2005-00194, Savannah River Site, Aiken, SC 29808 (2005).

4 Herman, C. C, D. R. Best, D. P. Lambert, M. E. Stone, and M. F. Williams, Sludge Batch 4 without Tank 4 Simulant Flowsheet Studies: Phase I SRAT Results, WSRC-TR-2005-00493, Savannah River Site, Aiken, SC 29808 (2005).

5 Larsen, D. D. SB-5 Projected Compositions, e-mail dated 5/5/2008 4:38 pm.

6 Choi, A. S. SB5 Projections 2, e-mail dated 6/12/2008 10:15 am.

7 Reboul, S. H., Noble Metals in As-Received Tank 51 SB5 Qualification Sample, SRNL-PSE-001222008-00115, Revision 0, Savannah River Site, Aiken, SC 29808 (2006).

8 Stone, M. E., Lab-Scale CPC Equipment Set-up, SRNL-ITS-2006-00074, Savannah River Site, Aiken, SC 29808 (2008).

9 Manual L29, Procedure ITS-0094, Rev. 1, Laboratory Scale Chemical Process Cell Simulations, Savannah River Site, Aiken, SC 29808 (2005).

10 SB5 Flowsheet CPC Experiments, WSRC-NB-2008-00015.

11 Lambert, D. P., Acid Calculation Spreadsheet for DWPF Simulations, Revision 1 (Dated 8/14/06), SRNL-PSE-2006-00173, Savannah River Site, Aiken, SC 29808 (2006).

12 Jantzen, C.M., J.R. Zamecnik, D.C. Koopman, C.C. Herman, and J.B. Pickett, Electron Equivalents Model for Controlling Reduction-Oxidation (Redox) Equilibrium during High Level Waste (HLW) Vitrification, WSRC-TR-2003-00126, Savannah River Site, Aiken, SC 29808 (2003).

13 Lambert, D. P.., 4L SRAT R\&D Directions for SB5 Qualification Flowsheet Development, SRNL-PSE-2008-00118, Rev. 1, Savannah River Site, Aiken, SC 29808 (2008).

14 Lambert, D. P.., 4L SRAT R\&D Directions for SB5 Blend Flowsheet Development, SRNLPSE-2008-00145, Savannah River Site, Aiken, SC 29808 (2008).

15 Stone, M. E., Sludge Batch 4 Simulant Flowsheet Studies: Phase II Results, WSRC-STI2006-00109, Savannah River Site, Aiken, SC 29808 (2006).

16 Stone, M. E., FY06 Feed Preparation for Melt Rate Testing, WSRC-STI-2006-0007, Savannah River Site, Aiken, SC 29808 (2006).

17 Manual L29, Procedure ITS-0052, Rev. 1, "Vitrification of Melter Slurries for Glass Redox $\left(\mathrm{Fe}^{2+} / \Sigma \mathrm{Fe}\right)$ \& Chemical Composition Measurement", (2003).

18 Jantzen, C. M. and J. D. Newell, Defense Waste Processing Facility (DWPF) Sludge Batch 5 (SB5) REDOX Validation, SRNL-PSE-2008-00184, Savannah River Site, Aiken, SC 29808 (2008). 


\subsection{Acknowledgements}

The authors would like to acknowledge the following personnel and groups for their assistance in performing the studies and analyzing the required samples:

- D. P. Healy, M. F. Williams, V. J. Williams, J. W. Duvall, D. M. Marsh, and M. A. Pettis for preparing the sludge and ARP/MCU simulants.

- T. O. Burckhalter, J. W. Duvall, D. M. Marsh, I. A. Reamer, V. J. Williams, and R. J. Workman for performing the SRAT/SME runs and assisting with sample analysis.

- P. A. Simmons, W. T. Riley, S. L. Crump, and L. C. Johnson for providing sample analyses.

- M. F. Williams and J. M. Pareizs for assistance with calibration and running the gas chromatographs during the runs. 


\section{Appendix A-1: SRAT Receipt Sample Results}

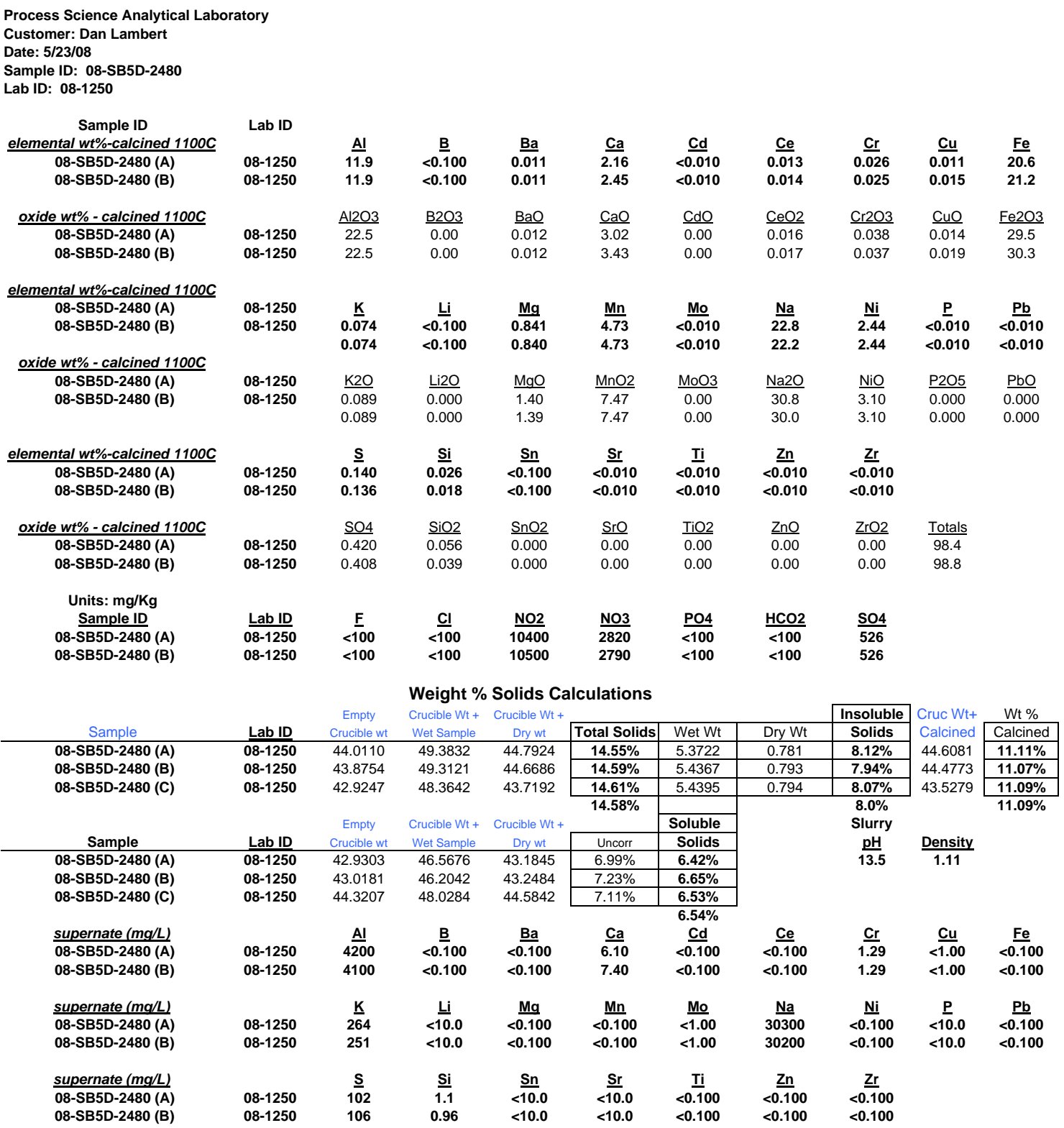

ACTL Results

Titration, Total Base

\begin{tabular}{|c|c|c|}
\hline & $\mathbf{p H ~ 7}$ & pH 5.5 \\
\hline Sample ID & $\begin{array}{c}\text { Result, m- } \\
\text { mole/g }\end{array}$ & $\begin{array}{c}\text { Result, } \mathbf{~ m - ~} \\
\text { mole/g }\end{array}$ \\
\hline SB5Da & 0.8203 & 0.9371 \\
\hline SB5Db & 0.8192 & 0.9363 \\
\hline SB5DC & 0.8170 & 0.9353 \\
\hline Average & $\mathbf{0 . 8 1 8 8}$ & $\mathbf{0 . 9 3 6 2}$ \\
\hline
\end{tabular}

AD Results

\begin{tabular}{|c|c|c|c|c|c|c|c|c|}
\hline Sample ID & $\begin{array}{c}\text { Mass Empty } \\
60 \mathrm{~mL} \\
\text { sample } \\
\text { bottle, } \mathrm{g}\end{array}$ & $\begin{array}{c}\text { Mass } \\
\text { sample } \\
\text { bottle with } \\
\text { sludge, g }\end{array}$ & $\begin{array}{l}\text { Sample } \\
\text { Mass, g }\end{array}$ & $\begin{array}{c}\text { Mass } \\
\text { sample } \\
\text { bottle with } \\
\text { sludge and } \\
\text { water, g }\end{array}$ & $\begin{array}{c}\text { Total Mass, } \\
\text { sample + } \\
\text { water, } \mathrm{g}\end{array}$ & $\begin{array}{c}\text { Total } \\
\text { Volume, } \\
\mathrm{mL}\end{array}$ & TIC, mg/L & $\begin{array}{c}\text { Corrected } \\
\mathrm{TIC}, \mathrm{mg} / \mathrm{kg}\end{array}$ \\
\hline 08_SB5D_2481A & 12.687 & 14.711 & 2.024 & 52.78 & 40.093 & 39.82 & 112 & 2,446 \\
\hline 08 SB5D 2481A & 12.756 & 14.77 & 2.014 & 52.899 & 40.143 & 39.87 & 115 & 2,527 \\
\hline 08 SB5D_2481A & 12.649 & 14.678 & 2.029 & 52.726 & 40.077 & 39.81 & 114 & 2,483 \\
\hline Average & & & & & & & & 2,485 \\
\hline
\end{tabular}


Appendix A-1: SRAT Receipt Sample Results

Process Science Analytical Laboratory Customer: Dan Lambert

Date: 7/02/08

Sample ID: 08-SB5C-2477 (SB5-C6-12-2008)

Lab ID: 08-1514

\begin{tabular}{c} 
Sample ID \\
elemental wt\%-calcined 1100C \\
\hline $08-S B 5 C-2477$ (A) \\
08-SB5C-2477 (B) \\
oxide wt\% - calcined 1100C \\
\hline $08-S B 5 C-2477$ (A) \\
08-SB5C-2477 (B) \\
elemental wt\%-calcined 1100C \\
\hline $08-S B 5 C-2477$ (A) \\
08-SB5C-2477 (B) \\
oxide wt\% - calcined 1100C \\
\hline $08-S B 5 C-2477$ (A) \\
08-SB5C-2477 (B) \\
elemental wt\%-calcined 1100C \\
\hline $08-S B 5 C-2477$ (A) \\
08-SB5C-2477 (B) \\
oxide wt\% - calcined 1100C \\
08-SB5C-2477 (A) \\
08-SB5C-2477 (B) \\
Units: mg/Kg \\
08-SB5C-2477 (B)
\end{tabular}

Lab ID
$08-1514$
$08-1514$

$\frac{\mathrm{Al}}{12.7} \quad \stackrel{\mathrm{B}}{<0.100}$

08-1514

08-1514

12.4

$<0.100$

$\frac{\mathrm{Ba}}{0.013}$

$\underline{\mathrm{Ca}}$

2.09
2.13

$\underline{\mathrm{Cd}}$

$<0.010$

Ce

0.023

Cr

$0.016 \quad 0.021$

$\underline{\mathrm{Fe}}$

$\underline{\mathrm{Al} 2 \mathrm{O} 3} \quad \underline{\mathrm{B} 2 \mathrm{O} 3}$

0.013

$\underline{\mathrm{CaO}}$

$\mathrm{CdO}$

$\frac{\mathrm{BaO}}{0.015}$

2.93

0.00

$\underline{\mathrm{CeO} 2}$

0.028

$\underline{\mathrm{Cr} 2 \mathrm{O} 3}$

0.025

$\mathrm{CuO}$

0.026

0.024

$\begin{array}{lll}0.015 & 2.98 & 0.00\end{array}$

0.028

0.023

P

$\stackrel{\text { Mo }}{0.010}$

$\underline{\mathrm{Na}} \quad \underline{\mathrm{Ni}}$

$\frac{\mathrm{Mg}}{0.890}$

$\frac{\mathrm{Mn}}{5.05}$

$<0.010$

17.6

2.63

$0 . \overline{111}$

0.111

$<\frac{\mathrm{Pb}}{0.010}$

08-1514

0.156

$<0.100$

$\mathrm{MgO}$

$\mathrm{MnO} 2$

$\underline{\mathrm{MoO} 3}$

$\mathrm{Na} 2 \mathrm{O}$

23.4

$\mathrm{NiO}$

3.34

$\underline{\mathrm{P} 2 \mathrm{O} 5} \quad \underline{\mathrm{PbO}}$

08-1514

0.190

$\frac{\mathrm{Li} 2 \mathrm{O}}{0.000}$

1.48

7.98
7.98

0.00

23.8

3.33

0.254

0.254

0.000

0.000

$08-1514 \quad \underline{S} \quad \underline{S i} \quad \underline{S}$

0.159

0.157

$\underline{\mathrm{Sr}}$

$\underline{\text { Ti }}$

$\underline{\mathrm{Zn}}$

$<0.010$

$\underline{\mathrm{Zr}}$

$<0.100$

$<0.100$

$<0.010$

$<0.010$

$<0.010$

$<0.010$

$\underline{\mathrm{SO} 4} \quad \underline{\mathrm{SiO} 2} \quad \underline{\mathrm{SnO} 2} \quad \underline{\mathrm{SrO}} \quad \underline{\mathrm{TiO} 2}$

08-1514

0.477

0.471

2.70

0.000

0.00

$\frac{\mathrm{ZnO}}{0.00}$

$\underline{\mathrm{ZrO} 2} \quad \underline{\text { Totals }}$

0.00

0.00

0.00

0.00

97.1

97.7

$\frac{\text { Lab ID }}{08-1514}$

08-1514

$\underset{<100}{\mathrm{~F}}$

$<\overline{100}$

Cl

$<100$

$\frac{\mathrm{NO} 2}{6210}$

NO3

$\frac{\mathrm{PO} 4}{<100}$

$\begin{array}{lll}\frac{\mathrm{HCO} 2}{<100} & \frac{\mathrm{SO} 4}{405} & \frac{\mathrm{C} 2 \mathrm{O} 4}{288} \\ <100 & 405 & 287\end{array}$

Weight \% Solids Calculations

\begin{tabular}{|c|c|c|c|c|c|c|c|c|c|c|}
\hline & & & \multicolumn{4}{|c|}{ 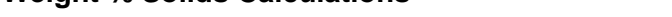 } & & \multirow{2}{*}{$\begin{array}{c}\text { Insoluble } \\
\text { Solids }\end{array}$} & \multirow{4}{*}{$\begin{array}{c}\text { Cruc Wt+ } \\
\text { Calcined } \\
45.1558 \\
45.8411\end{array}$} & Wt \% \\
\hline Sample & Lab ID & Crucible wt & Wet Sample & & Total Solids & Wet Wt & Dry Wt & & & Calcined \\
\hline 08-SB5C-2477 (A) & $08-1514$ & 44.6504 & 49.9708 & 45.3133 & $12.5 \%$ & 5.3204 & 0.663 & $7.82 \%$ & & $9.50 \%$ \\
\hline 08-SB5C-2477 (B) & 08-1514 & 45.3284 & 50.7093 & 45.9999 & $12.5 \%$ & 5.3809 & 0.671 & $7.88 \%$ & & $9.53 \%$ \\
\hline & & & & & 12.47 & & & 7.85 & & 9.51 \\
\hline & & Empty & Crucible Wt + & Crucible Wt + & & Soluble & & Slurry & & \\
\hline Sample & Lab ID & Crucible wt & Wet Sample & Dry wt & Uncorr & Solids & & $\mathrm{pH}$ & Density & \\
\hline 08-SB5C-2477 (A) & $08-1514$ & 45.4630 & 47.5642 & 45.5688 & $5.04 \%$ & $4.64 \%$ & & 13.4 & 1.09 & \\
\hline 08-SB5C-2477 (B) & 08-1514 & 44.7255 & 46.8160 & 44.8298 & $4.99 \%$ & $4.60 \%$ & & & & \\
\hline & & & & & & 4.62 & & & & \\
\hline
\end{tabular}

ACTL Results

Titration, Total Base

\begin{tabular}{|c|c|c|}
\hline & $\mathbf{p H ~ 7}$ & $\mathbf{p H ~ 5 . 5}$ \\
\hline Sample ID & $\begin{array}{c}\text { Result, m- } \\
\text { mole/g }\end{array}$ & $\begin{array}{c}\text { Result, m- } \\
\text { mole/g }\end{array}$ \\
\hline 2.1731 & 0.5822 & 0.6662 \\
\hline 2.1956 & 0.579 & 0.6648 \\
\hline 2.169 & 0.5774 & 0.663 \\
\hline Average & $\mathbf{0 . 5 7 9 5}$ & $\mathbf{0 . 6 6 4 7}$ \\
\hline
\end{tabular}

AD Results

\begin{tabular}{|c|c|c|c|c|c|c|c|c|}
\hline Sample ID & $\begin{array}{c}\text { Mass Empty } \\
60 \mathrm{~mL} \\
\text { sample } \\
\text { bottle, g }\end{array}$ & $\begin{array}{c}\text { Mass } \\
\text { sample } \\
\text { bottle with } \\
\text { sludge, } g\end{array}$ & $\begin{array}{l}\text { Sample } \\
\text { Mass, g }\end{array}$ & $\begin{array}{c}\text { Mass } \\
\text { sample } \\
\text { bottle with } \\
\text { sludge and } \\
\text { water, } g\end{array}$ & $\begin{array}{c}\text { Total Mass, } \\
\text { sample + } \\
\text { water, g }\end{array}$ & $\begin{array}{c}\text { Total } \\
\text { Volume, } \\
\text { mL }\end{array}$ & $\mathrm{TIC}, \mathrm{mg} / \mathrm{L}$ & $\begin{array}{l}\text { Corrected } \\
\text { TIC, } \mathrm{mg} / \mathrm{kg}\end{array}$ \\
\hline 08_SB5C_2478A & 12.556 & 14.57 & 2.014 & 52.576 & 40.02 & 39.79 & 72.6 & 1,434 \\
\hline 08_SB5C_2478B & 12.587 & 14.627 & 2.04 & 52.659 & 40.072 & 39.84 & 66.5 & 1,299 \\
\hline 08_SB5C_2478C & 12.574 & 14.614 & 2.04 & 52.906 & 40.332 & 40.09 & 65.2 & 1,281 \\
\hline Average & & & & & & & & 1,338 \\
\hline
\end{tabular}

Slurry Density, $\mathrm{g} / \mathrm{mL}$

1.09 


\begin{tabular}{|c|c|c|c|c|c|c|c|c|c|c|}
\hline \multicolumn{11}{|c|}{ Appendix A-2: SRAT Product Sample Results } \\
\hline & & & & & & & & & & \\
\hline \multicolumn{11}{|c|}{ SRNL Process Science Analytical Laboratory } \\
\hline \multicolumn{11}{|c|}{\begin{tabular}{|l|l} 
Customer: Dan Lambert & \\
\end{tabular}} \\
\hline \multicolumn{11}{|l|}{ Date: $8 / 1 / 08$} \\
\hline \multicolumn{11}{|c|}{ Sample ID: SRAT Prod - 08-SB5-7-2505, 9-2516, 8-2487, 10-2496 } \\
\hline \multicolumn{11}{|l|}{ Lab ID: 08-1372-1379 } \\
\hline \multicolumn{11}{|l|}{ Units: $w t \%, \mathrm{mg} / \mathrm{Kg}, \mathrm{mg} / \mathrm{L}$} \\
\hline & & & & & & & & & & \\
\hline Sample ID & Lab ID & & & & & & & & & \\
\hline elemental wt\%-calcined $1100 \mathrm{C}$ & & $\underline{\mathrm{Al}}$ & $\underline{\mathbf{B}}$ & Ba & $\underline{\text { Ca }}$ & $\underline{\mathrm{Cr}}$ & $\underline{\mathrm{Cu}}$ & Fe & $\underline{\mathbf{K}}$ & $\underline{\text { Li }}$ \\
\hline $\begin{array}{c}08-S B 5-7-2505(\mathrm{~A}) \\
\end{array}$ & 08-1372 & $\overline{11.4}$ & $<0 . \overline{100}$ & $\overline{0.013}$ & $\overline{2.04}$ & $0 . \overline{027}$ & $\overline{0.012}$ & $\overline{18.8}$ & $0 . \overline{084}$ & $<0 . \overline{100}$ \\
\hline 08-SB5-7-2505 (B) & 08-1372 & 11.4 & $<0.100$ & 0.013 & 2.17 & 0.027 & 0.024 & 18.4 & 0.085 & $<0.100$ \\
\hline 08-SB5-9-2516 (A) & 08-1373 & 11.4 & $<0.100$ & 0.014 & 2.18 & 0.029 & 0.011 & 18.4 & 0.117 & $<0.100$ \\
\hline 08-SB5-9-2516 (B) & $08-1373$ & 11.4 & $<0.100$ & 0.013 & 2.28 & 0.028 & 0.009 & 18.4 & 0.111 & $<0.100$ \\
\hline 08-SB5-8-2487 (A) & 08-1374 & 11.4 & $<0.100$ & 0.013 & 2.11 & 0.028 & 0.013 & 18.3 & 0.100 & $<0.100$ \\
\hline 08-SB5-8-2487 (B) & $08-1374$ & 11.3 & $<0.100$ & 0.013 & 2.05 & 0.028 & 0.015 & 18.5 & 0.099 & $<0.100$ \\
\hline 08-SB5-10-2496 (A) & 08-1375 & 11.8 & $<0.100$ & 0.014 & 2.00 & 0.029 & 0.016 & 18.6 & 0.088 & $<0.100$ \\
\hline 08-SB5-10-2496 (B) & 08-1375 & 11.7 & $<0.100$ & 0.013 & 1.92 & 0.028 & 0.014 & 18.8 & 0.089 & $<0.100$ \\
\hline oxide wt\% - calcined 1100C & & $\mathrm{Al} 2 \mathrm{O} 3$ & $\mathrm{~B} 2 \mathrm{O} 3$ & $\underline{\mathrm{BaO}}$ & $\mathrm{CaO}$ & $\mathrm{Cr} 2 \mathrm{O} 3$ & $\mathrm{CuO}$ & $\mathrm{Fe} 2 \mathrm{O} 3$ & $\mathrm{~K} 2 \mathrm{O}$ & $\underline{\mathrm{Li} 2 \mathrm{O}}$ \\
\hline 08-SB5-7-2505 (A) & 08-1372 & $\overline{21.6}$ & $\overline{0.0}$ & $\overline{0.015}$ & $\overline{2.86}$ & $\overline{0.040}$ & $\overline{0.015}$ & $\overline{26.9}$ & $\overline{0.101}$ & $\overline{0.000}$ \\
\hline 08-SB5-7-2505 (B) & 08-1372 & 21.5 & 0.0 & 0.015 & 3.04 & 0.040 & 0.030 & 26.3 & 0.102 & 0.000 \\
\hline 08-SB5-9-2516 (A) & 08-1373 & 21.6 & 0.0 & 0.015 & 3.06 & 0.042 & 0.014 & 26.3 & 0.141 & 0.000 \\
\hline 08-SB5-9-2516 (B) & 08-1373 & 21.5 & 0.0 & 0.015 & 3.19 & 0.041 & 0.012 & 26.3 & 0.133 & 0.000 \\
\hline 08-SB5-8-2487 (A) & 08-1374 & 21.6 & 0.0 & 0.015 & 2.96 & 0.041 & 0.016 & 26.1 & 0.119 & 0.000 \\
\hline 08-SB5-8-2487 (B) & 08-1374 & 21.4 & 0.0 & 0.015 & 2.86 & 0.041 & 0.018 & 26.4 & 0.119 & 0.000 \\
\hline 08-SB5-10-2496 (A) & 08-1375 & 22.3 & 0.0 & 0.015 & 2.79 & 0.042 & 0.020 & 26.6 & 0.106 & 0.000 \\
\hline 08-SB5-10-2496 (B) & 08-1375 & 22.2 & 0.0 & 0.015 & 2.69 & 0.042 & 0.018 & 26.8 & 0.106 & 0.000 \\
\hline elemental wt\%-calcined 1100C & & $\mathrm{Mg}$ & $\mathrm{Mn}$ & $\underline{\mathrm{Na}}$ & $\underline{\mathrm{Ni}}$ & $\underline{\mathbf{P}}$ & $\underline{\mathrm{Pb}}$ & $\underline{\mathbf{P d}}$ & $\underline{\mathrm{Rh}}$ & $\underline{\mathrm{Ru}}$ \\
\hline \begin{tabular}{|c|}
$08-S B 5-7-2505(\mathrm{~A})$ \\
\end{tabular} & 08-1372 & $0 . \overline{845}$ & $\overline{4.51}$ & $\overline{22.4}$ & $2 . \overline{33}$ & $<\overline{0.100}$ & $<\overline{0.010}$ & $<\overline{0.100}$ & $<\overline{0.100}$ & $\overline{0.014}$ \\
\hline 08-SB5-7-2505 (B) & 08-1372 & 0.841 & 4.44 & 22.4 & 2.28 & $<0.100$ & $<0.010$ & $<0.100$ & $<0.100$ & 0.023 \\
\hline 08-SB5-9-2516 (A) & 08-1373 & 0.852 & 4.31 & 22.5 & 2.27 & $<0.100$ & $<0.010$ & $<0.100$ & $<0.100$ & 0.014 \\
\hline 08-SB5-9-2516 (B) & 08-1373 & 0.852 & 4.33 & 22.4 & 2.28 & $<0.100$ & $<0.010$ & $<0.100$ & $<0.100$ & 0.014 \\
\hline 08-SB5-8-2487 (A) & 08-1374 & 0.847 & 4.49 & 22.4 & 2.29 & $<0.100$ & $<0.010$ & $<0.100$ & $<0.100$ & 0.014 \\
\hline 08-SB5-8-2487 (B) & $08-1374$ & 0.853 & 4.53 & 22.1 & 2.31 & $<0.100$ & $<0.010$ & $<0.100$ & $<0.100$ & 0.016 \\
\hline 08-SB5-10-2496 (A) & 08-1375 & 0.857 & 4.27 & 21.9 & 2.24 & $<0.100$ & $<0.010$ & $<0.100$ & $<0.100$ & 0.014 \\
\hline 08-SB5-10-2496 (B) & 08-1375 & 0.863 & 4.35 & 21.8 & 2.27 & $<0.100$ & $<0.010$ & $<0.100$ & $<0.100$ & 0.013 \\
\hline oxide wt\% - calcined 1100C & & $\underline{\mathrm{MgO}}$ & $\mathrm{MnO} 2$ & $\mathrm{Na2O}$ & $\underline{\mathrm{NiO}}$ & $\mathrm{P} 2 \mathrm{O5}$ & $\mathrm{PbO}$ & $\mathrm{PdO}$ & $\underline{\mathrm{RhO} 2}$ & $\underline{\mathrm{RuO} 2}$ \\
\hline 08-SB5-7-2505 (A) & 08-1372 & $\overline{1.40}$ & 7.13 & $\overline{30.2}$ & $\overline{2.96}$ & $\overline{0.000}$ & $\overline{0.000}$ & $\overline{0.000}$ & $\overline{0.000}$ & $\overline{0.018}$ \\
\hline 08-SB5-7-2505 (B) & 08-1372 & 1.40 & 7.01 & 30.3 & 2.89 & 0.000 & 0.000 & 0.000 & 0.000 & 0.030 \\
\hline 08-SB5-9-2516 (A) & 08-1373 & 1.41 & 6.81 & 30.4 & 2.88 & 0.000 & 0.000 & 0.000 & 0.000 & 0.019 \\
\hline 08-SB5-9-2516 (B) & 08-1373 & 1.41 & 6.85 & 30.2 & 2.90 & 0.000 & 0.000 & 0.000 & 0.000 & 0.018 \\
\hline 08-SB5-8-2487 (A) & 08-1374 & 1.41 & 7.10 & 30.2 & 2.90 & 0.000 & 0.000 & 0.000 & 0.000 & 0.019 \\
\hline 08-SB5-8-2487 (B) & 08-1374 & 1.42 & 7.16 & 29.8 & 2.94 & 0.000 & 0.000 & 0.000 & 0.000 & 0.021 \\
\hline 08-SB5-10-2496 (A) & 08-1375 & 1.42 & 6.74 & 29.6 & 2.84 & 0.000 & 0.000 & 0.000 & 0.000 & 0.018 \\
\hline 08-SB5-10-2496 (B) & 08-1375 & 1.43 & 6.87 & 29.5 & 2.88 & 0.000 & 0.000 & 0.000 & 0.000 & 0.017 \\
\hline elemental wt\%-calcined 1100C & & $\underline{\mathbf{S}}$ & $\underline{\underline{S i}}$ & $\underline{\underline{S n}}$ & $\underline{\mathrm{Sr}}$ & $\underline{\text { Ti }}$ & $\underline{\underline{Z n}}$ & $\underline{\mathrm{Zr}}$ & & \\
\hline 08-SB5-7-2505 (A) & 08-1372 & 0.161 & 0.051 & 0.020 & $<0.010$ & $<0.010$ & $<0.010$ & $<0.010$ & & \\
\hline 08-SB5-7-2505 (B) & 08-1372 & 0.165 & 0.045 & 0.023 & $<0.010$ & $<0.010$ & $<0.010$ & $<0.010$ & & \\
\hline $08-S B 5-9-2516(A)$ & 08-1373 & 0.168 & 0.051 & 0.023 & $<0.010$ & $<0.010$ & $<0.010$ & $<0.010$ & & \\
\hline 08-SB5-9-2516 (B) & 08-1373 & 0.168 & 0.048 & 0.022 & $<0.010$ & $<0.010$ & $<0.010$ & $<0.010$ & & \\
\hline 08-SB5-8-2487 (A) & 08-1374 & 0.168 & 0.048 & 0.022 & $<0.010$ & $<0.010$ & $<0.010$ & $<0.010$ & & \\
\hline 08-SB5-8-2487 (B) & 08-1374 & 0.171 & 0.045 & 0.023 & $<0.010$ & $<0.010$ & $<0.010$ & $<0.010$ & & \\
\hline 08-SB5-10-2496 (A) & 08-1375 & 0.167 & 0.039 & 0.023 & $<0.010$ & $<0.010$ & $<0.010$ & $<0.010$ & & \\
\hline 08-SB5-10-2496 (B) & 08-1375 & 0.164 & 0.040 & 0.021 & $<0.010$ & $<0.010$ & $<0.010$ & $<0.010$ & & \\
\hline oxide wt\% - calcined 1100C & & SO4 & $\mathrm{SiO} 2$ & $\mathrm{SnO} 2$ & $\underline{\mathrm{SrO}}$ & $\mathrm{TiO} 2$ & $\mathrm{ZnO}$ & $\mathrm{ZrO} 2$ & Totals & \\
\hline 08-SB5-7-2505 (A) & 08-1372 & $\overline{0.483}$ & $\overline{0.108}$ & $\overline{0.026}$ & $\overline{0.00}$ & $\overline{0.00}$ & $\overline{0.00}$ & $\overline{0.00}$ & 93.8 & \\
\hline 08-SB5-7-2505 (B) & 08-1372 & 0.494 & 0.097 & 0.030 & 0.00 & 0.00 & 0.00 & 0.00 & 93.3 & \\
\hline 08-SB5-9-2516 (A) & 08-1373 & 0.505 & 0.108 & 0.029 & 0.00 & 0.00 & 0.00 & 0.00 & 93.3 & \\
\hline 08-SB5-9-2516 (B) & 08-1373 & 0.503 & 0.102 & 0.028 & 0.00 & 0.00 & 0.00 & 0.00 & 93.2 & \\
\hline 08-SB5-8-2487 (A) & 08-1374 & 0.505 & 0.102 & 0.028 & 0.00 & 0.00 & 0.00 & 0.00 & 93.1 & \\
\hline 08-SB5-8-2487 (B) & 08-1374 & 0.514 & 0.096 & 0.029 & 0.00 & 0.00 & 0.00 & 0.00 & 92.9 & \\
\hline $08-S B 5-10-2496$ (A) & $08-1375$ & 0.501 & 0.084 & 0.029 & 0.00 & 0.00 & 0.00 & 0.00 & 93.1 & \\
\hline 08-SB5-10-2496 (B) & 08-1375 & 0.492 & 0.085 & 0.027 & 0.00 & 0.00 & 0.00 & 0.00 & 93.2 & \\
\hline
\end{tabular}




\begin{tabular}{|c|c|c|c|c|c|c|c|c|c|c|}
\hline anions $(\mathrm{mg} / \mathrm{Kg})$ & & $\underline{\mathbf{F}}$ & $\underline{\mathrm{Cl}}$ & $\underline{\mathrm{NO} 2}$ & $\underline{\mathrm{NO} 3}$ & $\underline{\mathrm{SO4}}$ & PO4 & $\underline{\mathrm{HCO} 2}$ & & \\
\hline 08-SB5-7-2505 (A) & 08-1372 & $<100$ & 314 & $<100$ & 29300 & $<100$ & $<100$ & 62000 & & \\
\hline 08-SB5-7-2505 (B) & 08-1372 & $<100$ & 318 & $<100$ & 29800 & $<100$ & $<100$ & 62400 & & \\
\hline 08-SB5-9-2516 (A) & 08-1373 & $<100$ & 323 & $<100$ & 34400 & 235 & $<100$ & 70900 & & \\
\hline 08-SB5-9-2516 (B) & 08-1373 & $<100$ & 327 & $<100$ & 35300 & 237 & $<100$ & 72500 & & \\
\hline 08-SB5-8-2487 (A) & 08-1374 & $<100$ & 337 & $<100$ & 31200 & 150 & $<100$ & 67500 & & \\
\hline 08-SB5-8-2487 (B) & 08-1374 & $<100$ & 339 & $<100$ & 31300 & 155 & $<100$ & 67300 & & \\
\hline 08-SB5-10-2496 (A) & 08-1375 & $<100$ & 311 & $<100$ & 38200 & 283 & $<100$ & 77600 & & \\
\hline 08-SB5-10-2496 (B) & 08-1375 & $<100$ & 313 & $<100$ & 38000 & 281 & $<100$ & 77800 & & \\
\hline 08-SB5-7-2505 & 08-1372 & $<100$ & 316 & $<100$ & 29,550 & $<100$ & $<100$ & 62,200 & & \\
\hline 08-SB5-9-2516 & 08-1373 & $<100$ & 325 & $<100$ & 34,850 & 194 & $<100$ & 71,700 & & \\
\hline 08-SB5-8-2487 & 08-1374 & $<100$ & 338 & $<100$ & 31,250 & 153 & $<100$ & 67,400 & & \\
\hline \multirow[t]{3}{*}{ 08-SB5-10-2496 } & 08-1375 & $<100$ & 312 & $<100$ & 38,100 & 282 & $<100$ & 77,700 & & \\
\hline & & \multicolumn{4}{|c|}{ Weight \% Solids Calculations } & & & & & \\
\hline & & Empty & Crucible Wt + & Crucible Wt + & & & & Insoluble & Cruc Wt+ & Wt \% \\
\hline Sample & & Crucible wt & Wet Sample & Dry wt & Total Solids & Wet Wt & Dry Wt & Solids & Calcined & Calcined \\
\hline 08-SB5-7-2505 (A) & $08-1372$ & 43.7363 & 49.5856 & 45.2355 & $25.6 \%$ & 5.8493 & 1.499 & $10.8 \%$ & 44.6329 & $15.3 \%$ \\
\hline \multirow[t]{2}{*}{ 08-SB5-7-2505 (B) } & 08-1372 & 43.0288 & 48.9617 & 44.5508 & $25.7 \%$ & 5.9329 & 1.522 & $11.1 \%$ & 43.9384 & $15.3 \%$ \\
\hline & & & & & $25.642 \%$ & & & $10.922 \%$ & & $15.330 \%$ \\
\hline 08-SB5-9-2516 (A) & 08-1373 & 42.3517 & 48.2841 & 43.7763 & $24.0 \%$ & 5.9324 & 1.425 & $10.9 \%$ & 43.1637 & $13.7 \%$ \\
\hline \multirow[t]{2}{*}{ 08-SB5-9-2516 (B) } & 08-1373 & 43.8465 & 49.7728 & 45.2689 & $24.0 \%$ & 5.9263 & 1.422 & $10.2 \%$ & 44.6554 & $13.6 \%$ \\
\hline & & & & & $24.008 \%$ & & & $10.579 \%$ & & $13.668 \%$ \\
\hline 08-SB5-8-2487 (A) & 08-1374 & 43.9078 & 49.6660 & 45.2862 & $23.9 \%$ & 5.7582 & 1.378 & $10.0 \%$ & 44.7059 & $13.9 \%$ \\
\hline \multirow[t]{2}{*}{ 08-SB5-8-2487 (B) } & 08-1374 & 43.9281 & 49.8130 & 45.3393 & $24.0 \%$ & 5.8849 & 1.411 & $9.68 \%$ & 44.7433 & $13.9 \%$ \\
\hline & & & & & $23.959 \%$ & & & $9.865 \%$ & & $13.856 \%$ \\
\hline 08-SB5-10-2496 (A) & 08-1375 & 43.2751 & 49.2118 & 44.7019 & $24.0 \%$ & 5.9367 & 1.427 & $10.8 \%$ & 44.0550 & $13.1 \%$ \\
\hline \multirow[t]{3}{*}{ 08-SB5-10-2496 (B) } & 08-1375 & 42.1893 & 48.1201 & 43.6308 & $24.3 \%$ & 5.9308 & 1.442 & $11.1 \%$ & 42.9754 & $13.3 \%$ \\
\hline & & & & & $24.169 \%$ & & & $10.912 \%$ & & $13.196 \%$ \\
\hline & & Empty & Crucible Wt + & Crucible Wt + & & Soluble & & & & \\
\hline Sample & & Crucible wt & Wet Sample & Dry wt & Uncorr & Solids & & $\mathrm{pH}$ & Density & \\
\hline 08-SB5-7-2505 (A) & 08-1372 & 42.3872 & 43.4910 & 42.5712 & $16.67 \%$ & $14.9 \%$ & & 8.12 & 1.181 & \\
\hline 08-SB5-7-2505 (B) & 08-1372 & 44.1676 & 45.2861 & 44.3508 & $16.38 \%$ & $14.6 \%$ & & & & \\
\hline 08-SB5-9-2516 (A) & $08-1373$ & 42.0052 & 43.1176 & 42.1686 & $14.69 \%$ & $13.1 \%$ & & 5.06 & 1.179 & \\
\hline 08-SB5-9-2516 (B) & 08-1373 & 44.0245 & 45.1468 & 44.1967 & $15.34 \%$ & $13.8 \%$ & & & & \\
\hline 08-SB5-8-2487 (A) & 08-1374 & 43.6629 & 44.7864 & 43.8364 & $15.44 \%$ & $13.9 \%$ & & 5.57 & 1.176 & \\
\hline 08-SB5-8-2487 (B) & $08-1374$ & 43.2445 & 44.3747 & 43.4234 & $15.83 \%$ & $14.3 \%$ & & & & \\
\hline 08-SB5-10-2496 (A) & 08-1375 & 44.9318 & 46.0514 & 45.0984 & $14.88 \%$ & $13.3 \%$ & & 4.87 & 1.181 & \\
\hline 08-SB5-10-2496 (B) & 08-1375 & 45.1006 & 46.2214 & 45.2674 & $14.88 \%$ & $13.2 \%$ & & & & \\
\hline
\end{tabular}




\begin{tabular}{|c|c|c|c|c|c|c|c|c|c|c|}
\hline \multicolumn{11}{|c|}{ Appendix A-2: SRAT Product Sample Results } \\
\hline & & & & & & & & & & \\
\hline \multicolumn{11}{|c|}{ SRNL Process Science Analytical Laboratory } \\
\hline \multicolumn{11}{|c|}{\begin{tabular}{|l|l} 
Customer: Dan Lambert & \\
\end{tabular}} \\
\hline \multicolumn{11}{|l|}{ Date: 8/1/08 } \\
\hline \multicolumn{11}{|c|}{ Sample ID: SRAT Prod - 08-SB5-11-2534, 12-2545, 13-2557, 14-2568 } \\
\hline \multicolumn{11}{|l|}{ Lab ID: 08-1526-1529 } \\
\hline \multicolumn{11}{|l|}{ Units: $w t \%, \mathrm{mg} / \mathrm{Kg}, \mathrm{mg} / \mathrm{L}$} \\
\hline Sample ID & Lab ID & & & & & & & & & \\
\hline elemental wt\%-calcined 1100C & & $\underline{\text { Al }}$ & B & Ba & $\underline{\text { Ca }}$ & $\underline{\mathrm{Cr}}$ & $\underline{\mathrm{Cu}}$ & $\mathrm{Fe}$ & $\underline{\mathbf{K}}$ & $\underline{\underline{L i}}$ \\
\hline 08-SB5-11-2534 (A) & 08-1526 & 12.2 & $<0.100$ & $0 . \overline{016}$ & $\overline{2.28}$ & $0 . \overline{019}$ & $0 . \overline{011}$ & $\overline{20.4}$ & $0 . \overline{180}$ & $<0.100$ \\
\hline 08-SB5-11-2534 (B) & $08-1526$ & 12.2 & $<0.100$ & 0.015 & 2.09 & 0.019 & 0.010 & 20.9 & 0.182 & $<0.100$ \\
\hline 08-SB5-12-2545 (A) & $08-1527$ & 12.4 & $<0.100$ & 0.016 & 2.05 & 0.020 & 0.012 & 21.1 & 0.159 & $<0.100$ \\
\hline 08-SB5-12-2545 (B) & $08-1527$ & 12.3 & $<0.100$ & 0.015 & 2.07 & 0.020 & 0.012 & 21.1 & 0.163 & $<0.100$ \\
\hline 08-SB5-13-2557 (A) & $08-1528$ & 12.2 & $<0.100$ & 0.016 & 2.14 & 0.020 & 0.007 & 20.0 & 0.151 & $<0.100$ \\
\hline 08-SB5-13-2557 (B) & $08-1528$ & 12.4 & $<0.100$ & 0.015 & 2.12 & 0.019 & 0.008 & 20.3 & 0.162 & $<0.100$ \\
\hline 08-SB5-14-2568 (A) & $08-1529$ & 12.1 & $<0.100$ & 0.016 & 2.02 & 0.019 & 0.010 & 20.1 & 0.239 & $<0.100$ \\
\hline 08-SB5-14-2568 (B) & $08-1529$ & 12.0 & $<0.100$ & 0.015 & 2.00 & 0.018 & 0.014 & 20.4 & 0.242 & $<0.100$ \\
\hline 08-SB5-15-2584 (A) & $08-1671$ & 10.9 & $<0.100$ & 0.037 & 2.14 & 0.032 & 0.013 & 17.5 & 0.154 & $<0.100$ \\
\hline 08-SB5-15-2584 (B) & $08-1671$ & 11.0 & $<0.100$ & 0.037 & 2.21 & 0.032 & 0.013 & 17.5 & 0.159 & $<0.100$ \\
\hline oxide wt\% - calcined 1100C & & $\mathrm{Al} 2 \mathrm{O} 3$ & $\mathrm{~B} 2 \mathrm{O} 3$ & $\underline{\mathrm{BaO}}$ & $\underline{\mathrm{CaO}}$ & $\mathrm{Cr} 2 \mathrm{O} 3$ & $\mathrm{CuO}$ & $\mathrm{Fe} 2 \mathrm{O} 3$ & $\underline{\mathrm{K} 2 \mathrm{O}}$ & $\underline{\mathrm{Li} 2 \mathrm{O}}$ \\
\hline 08-SB5-11-2534 (A) & $08-1526$ & $\overline{23.0}$ & $\overline{0.0}$ & $\overline{0.017}$ & $\overline{3.19}$ & $\overline{0.028}$ & $\overline{0.014}$ & $\overline{29.2}$ & $\overline{0.216}$ & $\overline{0.000}$ \\
\hline 08-SB5-11-2534 (B) & $08-1526$ & 23.0 & 0.0 & 0.017 & 2.93 & 0.027 & 0.013 & 29.8 & 0.219 & 0.000 \\
\hline 08-SB5-12-2545 (A) & 08-1527 & 23.5 & 0.0 & 0.018 & 2.87 & 0.029 & 0.015 & 30.1 & 0.191 & 0.000 \\
\hline 08-SB5-12-2545 (B) & $08-1527$ & 23.3 & 0.0 & 0.017 & 2.89 & 0.029 & 0.014 & 30.2 & 0.195 & 0.000 \\
\hline 08-SB5-13-2557 (A) & $08-1528$ & 23.1 & 0.0 & 0.018 & 3.00 & 0.029 & 0.009 & 28.6 & 0.182 & 0.000 \\
\hline 08-SB5-13-2557 (B) & $08-1528$ & 23.4 & 0.0 & 0.017 & 2.97 & 0.028 & 0.010 & 29.0 & 0.194 & 0.000 \\
\hline 08-SB5-14-2568 (A) & $08-1529$ & 22.9 & 0.0 & 0.017 & 2.82 & 0.028 & 0.012 & 28.8 & 0.287 & 0.000 \\
\hline 08-SB5-14-2568 (B) & 08-1529 & 22.7 & 0.0 & 0.016 & 2.80 & 0.027 & 0.017 & 29.2 & 0.290 & 0.000 \\
\hline 08-SB5-15-2584 (A) & $08-1671$ & 20.6 & 0.00 & 0.041 & 3.00 & 0.047 & 0.016 & 25.0 & 0.185 & 0.000 \\
\hline 08-SB5-15-2584 (B) & $08-1671$ & 20.8 & 0.00 & 0.041 & 3.10 & 0.047 & 0.016 & 25.0 & 0.191 & 0.000 \\
\hline elemental wt\%-calcined 1100C & & $\underline{\mathrm{Mg}}$ & $\underline{\mathrm{Mn}}$ & $\underline{\mathrm{Na}}$ & $\underline{\mathrm{Ni}}$ & $\underline{\mathbf{P}}$ & & & & \\
\hline 08-SB5-11-2534 (A) & $08-1526$ & 0.948 & $\overline{4.80}$ & $\overline{18.2}$ & $2 . \overline{24}$ & $0 . \overline{111}$ & & & & \\
\hline 08-SB5-11-2534 (B) & 08-1526 & 0.936 & 4.87 & 18.2 & 2.49 & 0.118 & & & & \\
\hline 08-SB5-12-2545 (A) & $08-1527$ & 0.978 & 4.87 & 18.4 & 2.52 & 0.121 & & & & \\
\hline 08-SB5-12-2545 (B) & 08-1527 & 0.950 & 4.92 & 18.1 & 2.29 & 0.119 & & & & \\
\hline 08-SB5-13-2557 (A) & 08-1528 & 0.973 & 4.82 & 17.7 & 2.45 & 0.118 & & & & \\
\hline 08-SB5-13-2557 (B) & $08-1528$ & 0.949 & 4.92 & 18.0 & 2.55 & 0.116 & & & & \\
\hline 08-SB5-14-2568 (A) & 08-1529 & 0.941 & 5.37 & 17.2 & 2.65 & 0.114 & & & & \\
\hline 08-SB5-14-2568 (B) & 08-1529 & 0.922 & 5.56 & 17.2 & 2.65 & 0.115 & & & & \\
\hline 08-SB5-15-2584 (A) & $08-1671$ & 0.833 & 3.95 & 20.5 & 1.97 & $<0.010$ & & & & \\
\hline 08-SB5-15-2584 (B) & $08-1671$ & 0.817 & 3.99 & 20.4 & 1.97 & $<0.010$ & & & & \\
\hline oxide wt\% - calcined 1100C & & $\mathrm{MgO}$ & $\underline{\mathrm{MnO} 2}$ & $\underline{\mathrm{Na} 2 \mathrm{O}}$ & $\underline{\mathrm{NiO}}$ & $\underline{\mathrm{P} 2 \mathrm{O5}}$ & & & & \\
\hline 08-SB5-11-2534 (A) & $08-1526$ & 1.57 & 7.59 & 24.5 & 2.84 & 0.255 & & & & \\
\hline 08-SB5-11-2534 (B) & $08-1526$ & 1.55 & 7.69 & 24.5 & 3.16 & 0.269 & & & & \\
\hline 08-SB5-12-2545 (A) & $08-1527$ & 1.62 & 7.69 & 24.8 & 3.20 & 0.276 & & & & \\
\hline 08-SB5-12-2545 (B) & 08-1527 & 1.58 & 7.77 & 24.5 & 2.91 & 0.273 & & & & \\
\hline 08-SB5-13-2557 (A) & $08-1528$ & 1.62 & 7.62 & 23.9 & 3.11 & 0.270 & & & & \\
\hline 08-SB5-13-2557 (B) & $08-1528$ & 1.58 & 7.77 & 24.3 & 3.24 & 0.266 & & & & \\
\hline 08-SB5-14-2568 (A) & $08-1529$ & 1.56 & 8.48 & 23.3 & 3.37 & 0.261 & & & & \\
\hline 08-SB5-14-2568 (B) & $08-1529$ & 1.53 & 8.79 & 23.2 & 3.37 & 0.263 & & & & \\
\hline 08-SB5-15-2584 (A) & $08-1671$ & 1.39 & 6.24 & 27.7 & 2.51 & 0.000 & & & & \\
\hline 08-SB5-15-2584 (B) & $08-1671$ & 1.41 & 6.30 & 27.5 & 2.50 & 0.000 & & & & \\
\hline & & & & & & & & & & \\
\hline
\end{tabular}




\begin{tabular}{|c|c|c|c|c|c|c|c|c|c|c|}
\hline elemental wt\%-calcined 1100C & & $\underline{\mathbf{S}}$ & $\underline{\underline{S i}}$ & $\underline{\mathrm{Sn}}$ & $\underline{\underline{S r}}$ & $\underline{\mathrm{Ti}}$ & $\underline{Z n}$ & $\underline{\mathrm{Zr}}$ & & \\
\hline 08-SB5-11-2534 (A) & 08-1526 & $0 . \overline{176}$ & $\overline{1.33}$ & $\overline{0.017}$ & $<0.010$ & $<0.010$ & $<\overline{0.010}$ & $<0.010$ & & \\
\hline 08-SB5-11-2534 (B) & 08-1526 & 0.180 & 1.24 & 0.015 & $<0.010$ & $<0.010$ & $<0.010$ & $<0.010$ & & \\
\hline 08-SB5-12-2545 (A) & 08-1527 & 0.178 & 1.25 & 0.016 & $<0.010$ & $<0.010$ & $<0.010$ & $<0.010$ & & \\
\hline 08-SB5-12-2545 (B) & 08-1527 & 0.179 & 1.25 & 0.017 & $<0.010$ & $<0.010$ & $<0.010$ & $<0.010$ & & \\
\hline 08-SB5-13-2557 (A) & 08-1528 & 0.178 & 1.24 & 0.018 & $<0.010$ & $<0.010$ & $<0.010$ & $<0.010$ & & \\
\hline 08-SB5-13-2557 (B) & 08-1528 & 0.177 & 1.23 & 0.016 & $<0.010$ & $<0.010$ & $<0.010$ & $<0.010$ & & \\
\hline 08-SB5-14-2568 (A) & 08-1529 & 0.179 & 1.35 & 0.023 & $<0.010$ & $<0.010$ & $<0.010$ & $<0.010$ & & \\
\hline 08-SB5-14-2568 (B) & 08-1529 & 0.178 & 1.30 & 0.020 & $<0.010$ & $<0.010$ & $<0.010$ & $<0.010$ & & \\
\hline 08-SB5-15-2584 (A) & 08-1671 & 0.337 & 1.16 & & & 3.64 & 0.043 & 0.062 & & \\
\hline 08-SB5-15-2584 (B) & 08-1671 & 0.342 & 1.15 & & & 3.73 & 0.033 & 0.066 & & \\
\hline oxide wt\% - calcined 1100C & & $\underline{\mathrm{SO} 4}$ & $\mathrm{SiO} 2$ & $\mathrm{SnO} 2$ & $\underline{\mathrm{SrO}}$ & $\underline{\mathrm{TiO} 2}$ & $\underline{\mathrm{ZnO}}$ & $\mathrm{ZrO} 2$ & um of Oxide & \\
\hline 08-SB5-11-2534 (A) & 08-1526 & $\overline{0.528}$ & $\overline{2.84}$ & $\overline{0.021}$ & $\overline{0.00}$ & $\overline{0.00}$ & $\overline{0.00}$ & $\overline{0.00}$ & 95.9 & \\
\hline 08-SB5-11-2534 (B) & 08-1526 & 0.539 & 2.66 & 0.019 & 0.00 & 0.00 & 0.00 & 0.00 & 96.5 & \\
\hline $08-S B 5-12-2545$ (A) & 08-1527 & 0.533 & 2.68 & 0.020 & 0.00 & 0.00 & 0.00 & 0.00 & 97.6 & \\
\hline 08-SB5-12-2545 (B) & 08-1527 & 0.536 & 2.67 & 0.021 & 0.00 & 0.00 & 0.00 & 0.00 & 96.9 & \\
\hline 08-SB5-13-2557 (A) & 08-1528 & 0.535 & 2.66 & 0.022 & 0.00 & 0.00 & 0.00 & 0.00 & 94.7 & \\
\hline 08-SB5-13-2557 (B) & 08-1528 & 0.530 & 2.64 & 0.020 & 0.00 & 0.00 & 0.00 & 0.00 & 96.0 & \\
\hline 08-SB5-14-2568 (A) & 08-1529 & 0.537 & 2.89 & 0.029 & 0.00 & 0.00 & 0.00 & 0.00 & 95.2 & \\
\hline 08-SB5-14-2568 (B) & $08-1529$ & 0.535 & 2.78 & 0.026 & 0.00 & 0.00 & 0.00 & 0.00 & 95.6 & \\
\hline 08-SB5-15-2584 (A) & $08-1671$ & 1.01 & 2.47 & & & 6.09 & 0.053 & 0.084 & 96.4 & \\
\hline 08-SB5-15-2584 (B) & 08-1671 & 1.02 & 2.46 & & & 6.23 & 0.041 & 0.089 & 96.7 & \\
\hline anions $(\mathrm{mg} / \mathrm{Kg})$ & & $\mathbf{F}$ & $\mathrm{Cl}$ & $\mathrm{NO2}$ & NO3 & SO4 & $\mathrm{PO4}$ & $\mathrm{HCO} 2$ & $\mathrm{C} 2 \mathrm{O} 4$ & \\
\hline 08-SB5-11-2534 (A) & $08-1526$ & $<100$ & $\overline{357}$ & $\overline{<100}$ & $\overline{20900}$ & $\overline{<100}$ & $\overline{<100}$ & $\overline{62900}$ & & \\
\hline 08-SB5-11-2534 (B) & 08-1526 & $<100$ & 355 & $<100$ & 20300 & $<100$ & $<100$ & 61600 & & \\
\hline 08-SB5-12-2545 (A) & 08-1527 & $<100$ & 327 & $<100$ & 23600 & $<100$ & $<100$ & 58400 & & \\
\hline 08-SB5-12-2545 (B) & 08-1527 & $<100$ & 330 & $<100$ & 23600 & $<100$ & $<100$ & 58000 & & \\
\hline 08-SB5-13-2557 (A) & 08-1528 & $<100$ & 331 & $<100$ & 26700 & $<100$ & $<100$ & 62800 & & \\
\hline 08-SB5-13-2557 (B) & 08-1528 & $<100$ & 333 & $<100$ & 25600 & 108 & $<100$ & 60600 & & \\
\hline 08-SB5-14-2568 (A) & 08-1529 & $<100$ & 342 & $<100$ & 28400 & 186 & $<100$ & 73900 & & \\
\hline 08-SB5-14-2568 (B) & 08-1529 & $<100$ & 341 & $<100$ & 28800 & 184 & $<100$ & 74900 & & \\
\hline 08-SB5-15-2584 (A) & 08-1671 & & 352 & $<100$ & 27900 & 2040 & & 57200 & 1930 & \\
\hline 08-SB5-15-2584 (B) & 08-1671 & & 348 & $<100$ & 28000 & 2150 & & 57200 & 1850 & \\
\hline & & & & & & & & & & \\
\hline & & \multicolumn{4}{|c|}{ Weight \% Solids Calculations } & & & & & \\
\hline & & Empty & Crucible Wt + & Crucible Wt + & & & & Insoluble & Cruc Wt+ & Wt \% \\
\hline Sample & & Crucible wt & Wet Sample & Dry wt & Total Solids & Wet Wt & Dry Wt & Solids & Calcined & Calcined \\
\hline 08-SB5-11-2534 (A) & 08-1526 & 43.6795 & 49.2695 & 45.1832 & $26.90 \%$ & 5.5900 & 1.504 & $13.6 \%$ & 44.6093 & $16.6 \%$ \\
\hline 08-SB5-11-2534 (B) & 08-1526 & 43.7421 & 49.2371 & 45.2256 & $27.00 \%$ & 5.4950 & 1.484 & $14.1 \%$ & 44.6605 & $16.7 \%$ \\
\hline 08-SB5-12-2545 (A) & 08-1527 & 44.8901 & 50.497 & 46.3169 & $25.45 \%$ & 5.6069 & 1.427 & $12.2 \%$ & 45.7587 & $15.5 \%$ \\
\hline 08-SB5-12-2545 (B) & 08-1527 & 43.0164 & 48.6843 & 44.4676 & $25.60 \%$ & 5.6679 & 1.451 & $12.4 \%$ & 43.902 & $15.6 \%$ \\
\hline $08-S B 5-13-2557$ (A) & 08-1528 & 42.3529 & 48.1796 & 43.8481 & $25.66 \%$ & 5.8267 & 1.495 & $13.4 \%$ & 43.2379 & $15.2 \%$ \\
\hline 08-SB5-13-2557 (B) & 08-1528 & 43.2346 & 48.9672 & 44.7072 & $25.69 \%$ & 5.7326 & 1.473 & $13.5 \%$ & 44.1066 & $15.2 \%$ \\
\hline 08-SB5-14-2568 (A) & 08-1529 & 42.1907 & 48.0666 & 43.7541 & $26.61 \%$ & 5.8759 & 1.563 & $14.6 \%$ & 43.0870 & $15.3 \%$ \\
\hline 08-SB5-14-2568 (B) & 08-1529 & 43.0300 & 48.995 & 44.6408 & $27.00 \%$ & 5.9650 & 1.611 & $15.1 \%$ & 43.9514 & $15.4 \%$ \\
\hline 08-SB5-15-2584 (A) & 08-1671 & 43.2270 & 48.7308 & 44.5758 & $24.51 \%$ & 5.5038 & 1.349 & $11.4 \%$ & 44.0509 & $15.0 \%$ \\
\hline \multirow[t]{2}{*}{ 08-SB5-15-2584 (B) } & 08-1671 & 44.0044 & 49.3758 & 45.3148 & $24.40 \%$ & 5.3714 & 1.310 & $11.7 \%$ & 44.8008 & $14.8 \%$ \\
\hline & & Empty & Crucible Wt + & Crucible Wt + & & Soluble & & & & \\
\hline Sample & & Crucible wt & Wet Sample & Dry wt & Uncorr & Solids & & pH & Density & \\
\hline $08-S B 5-11-2534$ (A) & $08-1526$ & 42.5148 & 44.7414 & 42.8579 & $15.41 \%$ & $13.3 \%$ & & 4.22 & 1.204 & \\
\hline 08-SB5-11-2534 (B) & 08-1526 & 44.0144 & 46.2463 & 44.3494 & $15.01 \%$ & $12.9 \%$ & & & & \\
\hline 08-SB5-12-2545 (A) & 08-1527 & 42.5167 & 44.7437 & 42.8536 & $15.13 \%$ & $13.3 \%$ & & 4.12 & 1.195 & \\
\hline 08-SB5-12-2545 (B) & $08-1527$ & 45.1075 & 47.3019 & 45.4381 & $15.07 \%$ & $13.2 \%$ & & & & \\
\hline 08-SB5-13-2557 (A) & 08-1528 & 44.5483 & 46.7650 & 44.8615 & $14.13 \%$ & $12.2 \%$ & & 4.04 & 1.193 & \\
\hline 08-SB5-13-2557 (B) & 08-1528 & 43.2708 & 45.5011 & 43.5849 & $14.08 \%$ & $12.2 \%$ & & & & \\
\hline $08-S B 5-14-2568$ (A) & 08-1529 & 42.3673 & 44.5880 & 42.6804 & $14.10 \%$ & $12.0 \%$ & & 4.11 & 1.192 & \\
\hline 08-SB5-14-2568 (B) & 08-1529 & 40.4674 & 42.6912 & 40.7788 & $14.00 \%$ & $11.9 \%$ & & & & \\
\hline 08-SB5-15-2584 (A) & 08-1671 & 42.5073 & 43.6253 & 42.6729 & $14.81 \%$ & $13.13 \%$ & & 5.38 & 1.173 & \\
\hline 08-SB5-15-2584 (B) & 08-1671 & 40.4369 & 41.5548 & 40.5980 & $14.41 \%$ & $12.73 \%$ & & & & \\
\hline
\end{tabular}




\begin{tabular}{|c|c|c|c|c|c|c|c|c|c|c|}
\hline \multicolumn{11}{|c|}{ Appendix A-3: SME Product Sample Results } \\
\hline & & & & & & & & & & \\
\hline \multicolumn{11}{|c|}{ SRNL Process Science Analytical Laboratory } \\
\hline \multicolumn{11}{|c|}{\begin{tabular}{|l|l|} 
Customer: Dan Lambert & \\
\end{tabular}} \\
\hline \multicolumn{11}{|l|}{ Date: $8 / 1 / 08$} \\
\hline \multicolumn{11}{|c|}{ Sample ID: SME Prod - 08-SB5-7-2514, 9-2525, 8-2529, 10-2530 } \\
\hline \multicolumn{11}{|c|}{\begin{tabular}{|l|l|l|l|} 
Lab ID: $08-1376-1379$ & & & \\
\end{tabular}} \\
\hline \multicolumn{11}{|l|}{ Units: $w \mathrm{wt} \% \mathrm{mg} / \mathrm{Kg}, \mathrm{mg} / \mathrm{L}$} \\
\hline & & & & & & & & & & \\
\hline Sample ID & Lab ID & & & & & & & & & \\
\hline elemental wt\%-calcined 1100C & & $\underline{\mathrm{Al}}$ & B & Ba & $\underline{\mathrm{Ca}}$ & $\underline{\mathrm{Cr}}$ & $\underline{\mathrm{Cu}}$ & $\mathrm{Fe}$ & $\underline{\mathbf{K}}$ & $\underline{\text { Li }}$ \\
\hline 08-SB5-7-2514 (A) & 08-1376 & 4.39 & 1.25 & $0 . \overline{011}$ & 0.580 & 0.020 & 0.025 & 6.94 & 0.077 & 2.20 \\
\hline $08-S B 5-7-2514$ (B) & $08-1376$ & 4.33 & 1.27 & 0.011 & 0.592 & 0.020 & 0.025 & 6.77 & 0.078 & 2.24 \\
\hline $08-S B 5-9-2525$ (A) & $08-1377$ & 4.29 & 1.42 & 0.011 & 0.556 & 0.020 & $<0.010$ & 6.78 & 0.098 & 2.23 \\
\hline 08-SB5-9-2525 (B) & $08-1377$ & 4.26 & 1.40 & 0.011 & 0.561 & 0.019 & $<0.010$ & 6.85 & 0.096 & 2.24 \\
\hline $08-S B 5-8-2529$ (A) & $08-1378$ & 4.30 & 1.33 & 0.011 & 0.592 & 0.020 & 0.017 & 6.96 & 0.100 & 2.21 \\
\hline 08-SB5-8-2529 (B) & $08-1378$ & 4.23 & 1.33 & 0.011 & 0.586 & 0.019 & 0.017 & 6.89 & 0.099 & 2.25 \\
\hline $08-S B 5-10-2530(A)$ & $08-1379$ & 4.22 & 1.30 & 0.011 & 0.605 & 0.020 & 0.020 & 6.67 & 0.098 & 2.16 \\
\hline 08-SB5-10-2530 (B) & $08-1379$ & 4.31 & 1.29 & 0.011 & 0.609 & 0.020 & 0.022 & 6.69 & 0.094 & 2.20 \\
\hline oxide wt\% - calcined 1100C & & $\mathrm{Al} 2 \mathrm{O} 3$ & $\mathrm{~B} 2 \mathrm{O} 3$ & $\underline{\mathrm{BaO}}$ & $\mathrm{CaO}$ & $\mathrm{Cr} 2 \mathrm{O} 3$ & $\mathrm{CuO}$ & $\mathrm{Fe} 2 \mathrm{O} 3$ & $\mathrm{~K} 2 \mathrm{O}$ & $\underline{\mathrm{Li} 2 \mathrm{O}}$ \\
\hline 08-SB5-7-2514 (A) & $08-1376$ & $\overline{8.30}$ & $\overline{4.03}$ & $\overline{0.012}$ & $\overline{0.812}$ & $\overline{0.029}$ & $\overline{0.032}$ & $\overline{9.93}$ & $\overline{0.093}$ & $\overline{4.73}$ \\
\hline 08-SB5-7-2514 (B) & $08-1376$ & 8.18 & 4.09 & 0.013 & 0.829 & 0.029 & 0.031 & 9.67 & 0.094 & 4.81 \\
\hline $08-S B 5-9-2525$ (A) & $08-1377$ & 8.10 & 4.57 & 0.012 & 0.778 & 0.029 & 0.000 & 9.70 & 0.117 & 4.79 \\
\hline 08-SB5-9-2525 (B) & $08-1377$ & 8.05 & 4.52 & 0.012 & 0.785 & 0.028 & 0.000 & 9.79 & 0.115 & 4.81 \\
\hline $08-S B 5-8-2529$ (A) & $08-1378$ & 8.12 & 4.28 & 0.012 & 0.829 & 0.029 & 0.021 & 9.96 & 0.120 & 4.75 \\
\hline 08-SB5-8-2529 (B) & $08-1378$ & 8.00 & 4.29 & 0.012 & 0.820 & 0.028 & 0.021 & 9.86 & 0.119 & 4.84 \\
\hline $08-S B 5-10-2530(A)$ & $08-1379$ & 7.98 & 4.18 & 0.013 & 0.847 & 0.029 & 0.025 & 9.54 & 0.117 & 4.65 \\
\hline 08-SB5-10-2530 (B) & 08-1379 & 8.14 & 4.16 & 0.012 & 0.853 & 0.029 & 0.027 & 9.57 & 0.113 & 4.72 \\
\hline elemental wt\%-calcined 1100C & & $\underline{\mathrm{Mg}}$ & $\underline{\mathrm{Mn}}$ & $\underline{\mathrm{Na}}$ & $\underline{\mathrm{Ni}}$ & $\underline{\mathbf{P}}$ & $\underline{\mathrm{Pb}}$ & $\underline{\underline{P d}}$ & $\underline{\mathbf{R h}}$ & $\underline{\mathrm{Ru}}$ \\
\hline \begin{tabular}{|c|}
$08-S B 5-7-2514(\mathrm{~A})$ \\
\end{tabular} & $08-1376$ & $0 . \overline{350}$ & $\overline{1.63}$ & $\overline{12.1}$ & $0 . \overline{801}$ & $<0 . \overline{100}$ & $<\overline{0.010}$ & $<\overline{0.100}$ & $<\overline{0.100}$ & $\overline{0.010}$ \\
\hline 08-SB5-7-2514 (B) & $08-1376$ & 0.346 & 1.60 & 12.0 & 0.794 & $<0.100$ & $<0.010$ & $<0.100$ & $<0.100$ & 0.013 \\
\hline 08-SB5-9-2525 (A) & $08-1377$ & 0.334 & 1.60 & 11.8 & 0.775 & $<0.100$ & $<0.010$ & $<0.100$ & $<0.100$ & $<0.010$ \\
\hline 08-SB5-9-2525 (B) & $08-1377$ & 0.335 & 1.62 & 11.8 & 0.772 & $<0.100$ & $<0.010$ & $<0.100$ & $<0.100$ & $<0.010$ \\
\hline $08-S B 5-8-2529(A)$ & $08-1378$ & 0.350 & 1.62 & 11.8 & 0.792 & $<0.100$ & 0.015 & $<0.100$ & $<0.100$ & $<0.010$ \\
\hline 08-SB5-8-2529 (B) & $08-1378$ & 0.346 & 1.60 & 11.6 & 0.784 & $<0.100$ & 0.014 & $<0.100$ & $<0.100$ & $<0.010$ \\
\hline 08-SB5-10-2530 (A) & 08-1379 & 0.342 & 1.55 & 11.8 & 0.784 & $<0.100$ & $<0.010$ & $<0.100$ & $<0.100$ & 0.013 \\
\hline 08-SB5-10-2530 (B) & $08-1379$ & 0.337 & 1.55 & 12.0 & 0.773 & $<0.100$ & $<0.010$ & $<0.100$ & $<0.100$ & 0.015 \\
\hline oxide wt\% - calcined 1100C & & $\mathrm{MgO}$ & $\underline{\mathrm{MnO} 2}$ & $\mathrm{Na2O}$ & $\underline{\mathrm{NiO}}$ & $\mathrm{P} 2 \mathrm{O} 5$ & $\mathrm{PbO}$ & $\mathrm{PdO}$ & RhO2 & RuO2 \\
\hline 08-SB5-7-2514 (A) & $08-1376$ & $\overline{0.581}$ & 2.57 & $\overline{16.4}$ & $\overline{1.02}$ & $\overline{0.000}$ & $\overline{0.000}$ & $\overline{0.000}$ & $\overline{0.000}$ & $\overline{0.014}$ \\
\hline 08-SB5-7-2514 (B) & $08-1376$ & 0.574 & 2.52 & 16.3 & 1.01 & 0.000 & 0.000 & 0.000 & 0.000 & 0.017 \\
\hline $08-S B 5-9-2525$ (A) & $08-1377$ & 0.554 & 2.52 & 15.9 & 0.984 & 0.000 & 0.000 & 0.000 & 0.000 & 0.000 \\
\hline 08-SB5-9-2525 (B) & 08-1377 & 0.555 & 2.55 & 15.9 & 0.980 & 0.000 & 0.000 & 0.000 & 0.000 & 0.000 \\
\hline $08-S B 5-8-2529(A)$ & $08-1378$ & 0.581 & 2.57 & 15.9 & 1.01 & 0.000 & 0.016 & 0.000 & 0.000 & 0.000 \\
\hline 08-SB5-8-2529 (B) & $08-1378$ & 0.574 & 2.53 & 15.7 & 1.00 & 0.000 & 0.016 & 0.000 & 0.000 & 0.000 \\
\hline 08-SB5-10-2530 (A) & 08-1379 & 0.568 & 2.45 & 16.0 & 1.00 & 0.000 & 0.000 & 0.000 & 0.000 & 0.017 \\
\hline 08-SB5-10-2530 (B) & $08-1379$ & 0.560 & 2.45 & 16.2 & 0.982 & 0.000 & 0.000 & 0.000 & 0.000 & 0.020 \\
\hline elemental wt\%-calcined 1100C & & $\underline{\mathbf{S}}$ & $\underline{\text { Si }}$ & $\underline{\underline{S n}}$ & $\underline{\mathrm{Sr}}$ & $\underline{\mathrm{Ti}}$ & $\underline{Z n}$ & $\underline{\underline{Z r}}$ & & \\
\hline 08-SB5-7-2514 (A) & 08-1376 & 0.063 & 24.1 & $<0.010$ & $<0.010$ & 0.039 & 0.010 & 0.091 & & \\
\hline 08-SB5-7-2514 (B) & $08-1376$ & 0.063 & 24.2 & $<0.010$ & $<0.010$ & 0.039 & 0.010 & 0.091 & & \\
\hline 08-SB5-9-2525 (A) & $08-1377$ & 0.053 & 24.7 & $<0.010$ & $<0.010$ & 0.041 & 0.020 & 0.093 & & \\
\hline 08-SB5-9-2525 (B) & $08-1377$ & 0.055 & 25.0 & $<0.010$ & $<0.010$ & 0.041 & 0.026 & 0.095 & & \\
\hline $08-S B 5-8-2529(A)$ & $08-1378$ & 0.056 & 24.4 & $<0.010$ & $<0.010$ & 0.039 & 0.009 & 0.093 & & \\
\hline 08-SB5-8-2529 (B) & $08-1378$ & 0.059 & 24.8 & $<0.010$ & $<0.010$ & 0.038 & 0.012 & 0.091 & & \\
\hline $08-S B 5-10-2530(A)$ & $08-1379$ & 0.061 & 23.9 & $<0.010$ & $<0.010$ & 0.041 & 0.012 & 0.111 & & \\
\hline 08-SB5-10-2530 (B) & $08-1379$ & 0.059 & 24.1 & $<0.010$ & $<0.010$ & 0.040 & 0.015 & 0.117 & & \\
\hline oxide wt\% - calcined 1100C & & $\underline{\mathrm{SO} 4}$ & $\underline{\mathrm{SiO} 2}$ & $\underline{\mathrm{SnO} 2}$ & $\underline{\mathrm{SrO}}$ & $\underline{\mathrm{TiO} 2}$ & $\mathrm{ZnO}$ & $\mathrm{ZrO} 2$ & Totals & \\
\hline 08-SB5-7-2514 (A) & $08-1376$ & 0.190 & $\overline{51.5}$ & 0.00 & $\overline{0.00}$ & 0.066 & 0.013 & $\overline{0.123}$ & 100 & \\
\hline 08-SB5-7-2514 (B) & $08-1376$ & 0.188 & 51.7 & 0.00 & 0.00 & 0.066 & 0.012 & 0.123 & 100 & \\
\hline $08-S B 5-9-2525(A)$ & $08-1377$ & 0.158 & 52.9 & 0.00 & 0.00 & 0.068 & 0.025 & 0.125 & 101 & \\
\hline 08-SB5-9-2525 (B) & 08-1377 & 0.165 & 53.4 & 0.00 & 0.00 & 0.068 & 0.032 & 0.128 & 102 & \\
\hline 08-SB5-8-2529 (A) & $08-1378$ & 0.167 & 52.1 & 0.00 & 0.00 & 0.064 & 0.011 & 0.126 & 101 & \\
\hline 08-SB5-8-2529 (B) & $08-1378$ & 0.176 & 53.2 & 0.00 & 0.00 & 0.064 & 0.015 & 0.123 & 101 & \\
\hline 08-SB5-10-2530 (A) & 08-1379 & 0.184 & 51.2 & 0.00 & 0.00 & 0.068 & 0.015 & 0.150 & 99 & \\
\hline 08-SB5-10-2530 (B) & 08-1379 & 0.177 & 51.5 & 0.00 & 0.00 & 0.067 & 0.019 & 0.157 & 100 & \\
\hline
\end{tabular}




\begin{tabular}{|c|c|c|c|c|c|c|c|c|c|c|}
\hline anions (mg/Kg) & & $\underline{F}$ & $\underline{\mathrm{Cl}}$ & $\mathrm{NO2}$ & $\mathrm{NO} 3$ & SO4 & $\mathrm{PO4}$ & $\mathrm{HCO} 2$ & & \\
\hline 08-SB5-7-2514(A) & 08-1376 & $<\overline{100}$ & $\overline{297}$ & $\overline{<100}$ & $\overline{17100}$ & $\overline{<100}$ & $\overline{<100}$ & $\overline{51100}$ & & \\
\hline 08-SB5-7-2514 (B) & 08-1376 & $<100$ & 296 & $<100$ & 17800 & $<100$ & $<100$ & 51500 & & \\
\hline 08-SB5-9-2525 (A) & 08-1377 & $<100$ & 279 & $<100$ & 18900 & $<100$ & $<100$ & 49300 & & \\
\hline 08-SB5-9-2525 (B) & 08-1377 & $<100$ & 283 & $<100$ & 19300 & $<100$ & $<100$ & 50300 & & \\
\hline 08-SB5-8-2529 (A) & 08-1378 & $<100$ & 280 & $<100$ & 21700 & 150 & $<100$ & 54600 & & \\
\hline 08-SB5-8-2529 (B) & 08-1378 & $<100$ & 279 & $<100$ & 21800 & 143 & $<100$ & 55100 & & \\
\hline 08-SB5-10-2530 (A) & 08-1379 & $<100$ & 310 & $<100$ & 25400 & 214 & $<100$ & 62900 & & \\
\hline \multirow[t]{3}{*}{ 08-SB5-10-2530 (B) } & 08-1379 & $<100$ & 308 & $<100$ & 24600 & 213 & $<100$ & 62000 & & \\
\hline & & \multicolumn{4}{|c|}{ Weight \% Solids Calculations } & & & & & \\
\hline & & Empty & Crucible Wt + & Crucible Wt + & & & & Insoluble & Cruc Wt+ & Wt \% \\
\hline Sample & & Crucible wt & Wet Sample & Dry wt & Total Solids & Wet Wt & Dry Wt & Solids & Calcined & Calcined \\
\hline 08-SB5-7-2514 (A) & 08-1376 & 44.6011 & 49.9916 & 47.1140 & $46.6 \%$ & 5.3905 & 2.513 & $33.2 \%$ & 46.6451 & $37.9 \%$ \\
\hline 08-SB5-7-2514 (B) & 08-1376 & 43.6724 & 47.979 & 45.6808 & $46.6 \%$ & 4.3066 & 2.008 & $32.6 \%$ & 45.3038 & $37.9 \%$ \\
\hline 08-SB5-9-2525 (A) & 08-1377 & 43.8488 & 50.4433 & 46.8182 & $45.0 \%$ & 6.5945 & 2.969 & $32.5 \%$ & 46.1950 & $35.6 \%$ \\
\hline 08-SB5-9-2525 (B) & 08-1377 & 43.3192 & 50.0942 & 46.3600 & $44.9 \%$ & 6.7750 & 3.041 & $32.7 \%$ & 45.7197 & $35.4 \%$ \\
\hline 08-SB5-8-2529 (A) & 08-1378 & 44.4342 & 50.7762 & 47.2625 & $44.6 \%$ & 6.3420 & 2.828 & $32.0 \%$ & 46.6985 & $35.7 \%$ \\
\hline 08-SB5-8-2529 (B) & 08-1378 & 42.9239 & 49.2524 & 45.7335 & $44.4 \%$ & 6.3285 & 2.810 & $32.4 \%$ & 45.1674 & $35.5 \%$ \\
\hline 08-SB5-10-2530 (A) & 08-1379 & 42.8934 & 49.4247 & 45.8113 & $44.7 \%$ & 6.5313 & 2.918 & $31.9 \%$ & 45.1812 & $35.0 \%$ \\
\hline \multirow[t]{2}{*}{ 08-SB5-10-2530 (B) } & 08-1379 & 42.2957 & 48.9031 & 45.2367 & $44.5 \%$ & 6.6074 & 2.941 & $32.4 \%$ & 44.5975 & $34.8 \%$ \\
\hline & & Empty & Crucible Wt + & Crucible Wt + & & Soluble & & & & \\
\hline Sample & & Crucible wt & Wet Sample & Dry wt & Uncorr & Solids & & $\mathrm{pH}$ & Density & Waste Loadi \\
\hline 08-SB5-7-2514 (A) & $08-1376$ & 43.2649 & 44.4064 & 43.4945 & $20.11 \%$ & $13.4 \%$ & & 8.26 & 1.344 & $35.7 \%$ \\
\hline 08-SB5-7-2514 (B) & 08-1376 & 44.0107 & 45.1540 & 44.2488 & $20.83 \%$ & $14.0 \%$ & & & & \\
\hline 08-SB5-9-2525 (A) & 08-1377 & 44.5394 & 45.6843 & 44.7524 & $18.60 \%$ & $12.6 \%$ & & 5.71 & 1.341 & $35.3 \%$ \\
\hline 08-SB5-9-2525 (B) & 08-1377 & 44.5039 & 45.6820 & 44.7175 & $18.13 \%$ & $12.2 \%$ & & & & \\
\hline 08-SB5-8-2529 (A) & 08-1378 & 44.3061 & 45.4411 & 44.5165 & $18.54 \%$ & $12.6 \%$ & & 7.22 & 1.340 & $35.3 \%$ \\
\hline 08-SB5-8-2529 (B) & 08-1378 & 42.9303 & 44.0851 & 43.1358 & $17.80 \%$ & $12.0 \%$ & & & & \\
\hline 08-SB5-10-2530 (A) & 08-1379 & 40.4607 & 41.5974 & 40.6740 & $18.76 \%$ & $12.8 \%$ & & 5.46 & 1.351 & $36.9 \%$ \\
\hline 08-SB5-10-2530 (B) & 08-1379 & 42.9057 & 44.0469 & 43.1106 & $17.95 \%$ & $12.1 \%$ & & & & \\
\hline
\end{tabular}




\begin{tabular}{|c|c|c|c|c|c|c|c|c|c|c|}
\hline \multicolumn{11}{|c|}{ Appendix A-3: SME Product Sample Results } \\
\hline & & & & & & & & & & \\
\hline \multicolumn{11}{|c|}{ SRNL Process Science Analytical Laboratory } \\
\hline \multicolumn{11}{|l|}{ Customer: Dan Lambert } \\
\hline \multicolumn{11}{|l|}{ Date: 8/1/08 } \\
\hline \multicolumn{11}{|c|}{ Sample ID: SME Prod - 08-SB5-11-2542, 12-2553, 13-2565, 14-2576 } \\
\hline \multirow{2}{*}{\multicolumn{11}{|c|}{$\begin{array}{l}\text { Lab ID: } 08-1530-1533 \\
\text { Units: } \mathrm{wt} \%, \mathrm{mg} / \mathrm{Kg}, \mathrm{mg} / \mathrm{L}\end{array}$}} \\
\hline & & & & & & & & & & \\
\hline & & & & & & & & & & \\
\hline Sample ID & Lab ID & & & & & & & & & \\
\hline elemental wt\%-calcined $1100 \mathrm{C}$ & & Al & B & $\mathrm{Ba}$ & $\mathrm{Ca}$ & $\mathrm{Cr}$ & $\mathrm{Cu}$ & $\mathrm{Fe}$ & $\underline{\mathbf{K}}$ & $\underline{\mathrm{Li}}$ \\
\hline 08-SB5-11-2542 (A) & 08-1530 & $4 \overline{59}$ & $1 . \overline{23}$ & $0 \overline{011}$ & $0 . \overline{626}$ & $0 . \overline{016}$ & $<\overline{0.010}$ & $\overline{7.24}$ & $0 . \overline{122}$ & $2 . \overline{13}$ \\
\hline 08-SB5-11-2542 (B) & 08-1530 & 4.59 & 1.28 & 0.011 & 0.656 & 0.016 & $<0.010$ & 7.32 & 0.117 & 2.19 \\
\hline 08-SB5-12-2553 (A) & 08-1531 & 4.61 & 1.29 & 0.011 & 0.624 & 0.016 & $<0.010$ & 7.35 & 0.106 & 2.25 \\
\hline 08-SB5-12-2553 (B) & $08-1531$ & 4.57 & 1.32 & 0.010 & 0.621 & 0.015 & $<0.010$ & 7.32 & 0.105 & 2.22 \\
\hline 08-SB5-13-2565 (A) & $08-1532$ & 4.70 & 1.28 & 0.011 & 0.614 & 0.017 & $<0.010$ & 7.52 & 0.116 & 2.21 \\
\hline 08-SB5-13-2565 (B) & $08-1532$ & 4.66 & 1.25 & 0.011 & 0.621 & 0.017 & $<0.010$ & 7.49 & 0.118 & 2.13 \\
\hline 08-SB5-14-2576 (A) & $08-1533$ & 4.48 & 1.28 & 0.011 & 0.637 & 0.016 & $<0.010$ & 7.23 & 0.144 & 2.22 \\
\hline 08-SB5-14-2576 (B) & $08-1533$ & 4.53 & 1.28 & 0.010 & 0.630 & 0.016 & $<0.010$ & 7.17 & 0.155 & 2.18 \\
\hline 08-SB5-15-2590 (A) & $08-1672$ & 3.82 & 1.39 & 0.012 & 0.560 & 0.019 & 0.017 & 5.64 & 0.088 & 2.10 \\
\hline 08-SB5-15-2590 (B) & 08-1672 & 3.87 & 1.40 & 0.013 & 0.587 & 0.020 & 0.020 & 5.96 & 0.092 & 2.10 \\
\hline oxide wt\% - calcined 1100C & & $\mathrm{Al} 2 \mathrm{O} 3$ & $\mathrm{~B} 2 \mathrm{O} 3$ & $\mathrm{BaO}$ & $\mathrm{CaO}$ & $\mathrm{Cr} 2 \mathrm{O} 3$ & $\mathrm{CuO}$ & $\mathrm{Fe} 2 \mathrm{O} 3$ & $\mathrm{~K} 2 \mathrm{O}$ & $\mathrm{Li} 2 \mathrm{O}$ \\
\hline 08-SB5-11-2542 (A) & $08-1530$ & 8.67 & 3.95 & 0.012 & 0.877 & 0.023 & $\overline{0.00}$ & 10.4 & 0.146 & 4.58 \\
\hline 08-SB5-11-2542 (B) & $08-1530$ & 8.68 & 4.11 & 0.013 & 0.918 & 0.024 & 0.00 & 10.5 & 0.140 & 4.71 \\
\hline 08-SB5-12-2553 (A) & $08-1531$ & 8.71 & 4.16 & 0.012 & 0.874 & 0.024 & 0.00 & 10.5 & 0.127 & 4.83 \\
\hline 08-SB5-12-2553 (B) & $08-1531$ & 8.64 & 4.26 & 0.012 & 0.870 & 0.023 & 0.00 & 10.5 & 0.126 & 4.77 \\
\hline 08-SB5-13-2565 (A) & $08-1532$ & 8.89 & 4.14 & 0.013 & 0.859 & 0.025 & 0.00 & 10.8 & 0.139 & 4.76 \\
\hline 08-SB5-13-2565 (B) & 08-1532 & 8.81 & 4.02 & 0.012 & 0.869 & 0.025 & 0.00 & 10.7 & 0.141 & 4.57 \\
\hline 08-SB5-14-2576 (A) & $08-1533$ & 8.47 & 4.11 & 0.012 & 0.891 & 0.024 & 0.00 & 10.3 & 0.172 & 4.76 \\
\hline 08-SB5-14-2576 (B) & $08-1533$ & 8.57 & 4.12 & 0.012 & 0.882 & 0.023 & 0.00 & 10.2 & 0.186 & 4.69 \\
\hline 08-SB5-15-2590 (A) & $08-1672$ & 7.21 & 4.47 & 0.014 & 0.785 & 0.027 & 0.021 & 8.07 & 0.106 & 4.51 \\
\hline 08-SB5-15-2590 (B) & 08-1672 & 7.32 & 4.50 & 0.015 & 0.821 & 0.029 & 0.025 & 8.52 & 0.111 & 4.52 \\
\hline \begin{tabular}{|l} 
elemental wt\%-calcined $1100 \mathrm{C}$ \\
\end{tabular} & & $\mathrm{Mg}$ & $\mathrm{Mn}$ & $\mathrm{Na}$ & $\mathrm{Ni}$ & $\underline{\mathbf{P}}$ & $\mathrm{Pb}$ & Pd & $\mathbf{R h}$ & \\
\hline 08-SB5-11-2542 (A) & $08-1530$ & 0.359 & 1.68 & 10.2 & 0.821 & $<0.100$ & 0.013 & $<0.100$ & $<0.100$ & \\
\hline 08-SB5-11-2542 (B) & $08-1530$ & 0.377 & 1.70 & 10.1 & 0.878 & $<0.100$ & 0.013 & $<0.100$ & $<0.100$ & \\
\hline 08-SB5-12-2553 (A) & $08-1531$ & 0.371 & 1.66 & 10.2 & 0.885 & $<0.100$ & $<0.010$ & $<0.100$ & $<0.100$ & \\
\hline 08-SB5-12-2553 (B) & $08-1531$ & 0.365 & 1.66 & 10.1 & 0.868 & $<0.100$ & $<0.010$ & $<0.100$ & $<0.100$ & \\
\hline 08-SB5-13-2565 (A) & $08-1532$ & 0.370 & 1.77 & 10.3 & 0.892 & $<0.100$ & $<0.010$ & $<0.100$ & $<0.100$ & \\
\hline 08-SB5-13-2565 (B) & $08-1532$ & 0.369 & 1.75 & 10.0 & 0.894 & $<0.100$ & $<0.010$ & $<0.100$ & $<0.100$ & \\
\hline 08-SB5-14-2576 (A) & $08-1533$ & 0.364 & 1.65 & 10.0 & 0.846 & $<0.100$ & 0.054 & $<0.100$ & $<0.100$ & \\
\hline 08-SB5-14-2576 (B) & $08-1533$ & 0.350 & 1.64 & 10.1 & 0.808 & $<0.100$ & 0.050 & $<0.100$ & $<0.100$ & \\
\hline 08-SB5-15-2590 (A) & $08-1672$ & 0.964 & 1.18 & 9.84 & 0.557 & $<0.010$ & $<0.010$ & $<0.100$ & $<0.100$ & \\
\hline 08-SB5-15-2590 (B) & $08-1672$ & 1.02 & 1.25 & 9.85 & 0.594 & $<0.010$ & $<0.010$ & $<0.100$ & $<0.100$ & \\
\hline oxide wt\% - calcined 1100C & & $\mathrm{MgO}$ & $\mathrm{MnO} 2$ & $\mathrm{Na} 2 \mathrm{O}$ & $\mathrm{NiO}$ & P2O5 & $\mathrm{PbO}$ & $\mathrm{PdO}$ & $\mathrm{RhO} 2$ & \\
\hline $08-S B 5-11-2542(A)$ & $08-1530$ & 0.596 & 2.65 & 13.7 & 1.04 & 0.000 & 0.014 & 0.000 & 0.000 & \\
\hline $08-S B 5-11-2542$ (B) & $08-1530$ & 0.626 & 2.68 & 13.6 & 1.11 & 0.000 & 0.014 & 0.000 & 0.000 & \\
\hline 08-SB5-12-2553 (A) & 08-1531 & 0.616 & 2.62 & 13.7 & 1.12 & 0.000 & 0.000 & 0.000 & 0.000 & \\
\hline 08-SB5-12-2553 (B) & $08-1531$ & 0.606 & 2.62 & 13.6 & 1.10 & 0.000 & 0.000 & 0.000 & 0.000 & \\
\hline 08-SB5-13-2565 (A) & $08-1532$ & 0.614 & 2.79 & 13.9 & 1.13 & 0.000 & 0.000 & 0.000 & 0.000 & \\
\hline 08-SB5-13-2565 (B) & 08-1532 & 0.613 & 2.76 & 13.5 & 1.13 & 0.000 & 0.000 & 0.000 & 0.000 & \\
\hline 08-SB5-14-2576 (A) & $08-1533$ & 0.604 & 2.61 & 13.4 & 1.07 & 0.000 & 0.059 & 0.000 & 0.000 & \\
\hline 08-SB5-14-2576 (B) & $08-1533$ & 0.581 & 2.59 & 13.6 & 1.03 & 0.000 & 0.055 & 0.000 & 0.000 & \\
\hline $08-S B 5-15-2590$ (A) & $08-1672$ & 1.60 & 1.86 & 13.3 & 0.708 & 0.000 & 0.000 & 0.000 & 0.000 & \\
\hline 08-SB5-15-2590 (B) & $08-1672$ & 1.69 & 1.98 & 13.3 & 0.754 & 0.000 & 0.000 & 0.000 & 0.000 & \\
\hline
\end{tabular}




\begin{tabular}{|c|c|c|c|c|c|c|c|c|c|c|}
\hline elemental wt\%-calcined $1100 \mathrm{C}$ & & Ru & $\underline{\mathbf{S}}$ & $\underline{\text { Si }}$ & $\underline{\mathrm{Sn}}$ & $\underline{\mathrm{Sr}}$ & $\underline{\mathrm{Ti}}$ & $\mathrm{Zn}$ & $\underline{\mathrm{Zr}}$ & \\
\hline 08-SB5-11-2542 (A) & $08-1530$ & $<\overline{0.010}$ & $0 . \overline{073}$ & $\overline{23.6}$ & $<\overline{0.010}$ & $<0 . \overline{010}$ & $0 . \overline{017}$ & $<\overline{0.010}$ & $0 . \overline{012}$ & \\
\hline 08-SB5-11-2542 (B) & $08-1530$ & $<0.010$ & 0.070 & 24.1 & $<0.010$ & $<0.010$ & 0.018 & $<0.010$ & 0.013 & \\
\hline 08-SB5-12-2553 (A) & 08-1531 & $<0.010$ & 0.070 & 24.6 & $<0.010$ & $<0.010$ & 0.018 & $<0.010$ & 0.015 & \\
\hline 08-SB5-12-2553 (B) & 08-1531 & $<0.010$ & 0.065 & 24.5 & $<0.010$ & $<0.010$ & 0.018 & $<0.010$ & 0.014 & \\
\hline 08-SB5-13-2565 (A) & $08-1532$ & $<0.010$ & 0.062 & 24.2 & $<0.010$ & $<0.010$ & 0.018 & $<0.010$ & 0.018 & \\
\hline 08-SB5-13-2565 (B) & 08-1532 & $<0.010$ & 0.061 & 23.1 & $<0.010$ & $<0.010$ & 0.023 & $<0.010$ & 0.019 & \\
\hline 08-SB5-14-2576 (A) & $08-1533$ & $<0.010$ & 0.066 & 24.1 & $<0.010$ & $<0.010$ & 0.018 & $<0.010$ & 0.016 & \\
\hline 08-SB5-14-2576 (B) & $08-1533$ & $<0.010$ & 0.065 & 23.9 & $<0.010$ & $<0.010$ & 0.018 & $<0.010$ & 0.017 & \\
\hline 08-SB5-15-2590 (A) & 08-1672 & 0.011 & 0.082 & 24.8 & & & 1.11 & 0.013 & 0.032 & \\
\hline 08-SB5-15-2590 (B) & $08-1672$ & 0.011 & 0.089 & 25.1 & & & 1.12 & 0.018 & 0.031 & \\
\hline oxide wt\% - calcined $1100 \mathrm{C}$ & & RuO2 & $\mathrm{SO} 4$ & $\mathrm{SiO} 2$ & $\mathrm{SnO} 2$ & $\mathrm{SrO}$ & TiO2 & $\mathrm{ZnO}$ & ZrO2 & Sum ofOxides \\
\hline 08-SB5-11-2542 (A) & $08-1530$ & $\overline{0.000}$ & $\overline{0.219}$ & $\overline{50.6}$ & $\overline{0.000}$ & $\overline{0.00}$ & $\overline{0.028}$ & $\overline{0.000}$ & $\overline{0.016}$ & 92.9 \\
\hline 08-SB5-11-2542 (B) & $08-1530$ & 0.000 & 0.209 & 51.6 & 0.000 & 0.00 & 0.029 & 0.000 & 0.017 & 94.2 \\
\hline 08-SB5-12-2553 (A) & $08-1531$ & 0.000 & 0.209 & 52.7 & 0.000 & 0.00 & 0.030 & 0.000 & 0.021 & 95.5 \\
\hline 08-SB5-12-2553 (B) & $08-1531$ & 0.000 & 0.195 & 52.3 & 0.000 & 0.00 & 0.029 & 0.000 & 0.018 & 94.9 \\
\hline 08-SB5-13-2565 (A) & 08-1532 & 0.000 & 0.185 & 51.9 & 0.000 & 0.00 & 0.029 & 0.000 & 0.024 & 95.3 \\
\hline 08-SB5-13-2565 (B) & 08-1532 & 0.000 & 0.184 & 49.5 & 0.000 & 0.00 & 0.038 & 0.000 & 0.025 & 92.4 \\
\hline 08-SB5-14-2576 (A) & 08-1533 & 0.000 & 0.197 & 51.6 & 0.000 & 0.00 & 0.030 & 0.000 & 0.022 & 93.6 \\
\hline 08-SB5-14-2576 (B) & $08-1533$ & 0.000 & 0.194 & 51.1 & 0.000 & 0.00 & 0.030 & 0.000 & 0.023 & 93.3 \\
\hline 08-SB5-15-2590 (A) & 08-1672 & 0.014 & 0.246 & 53.2 & & & 1.86 & 0.016 & 0.044 & 98.0 \\
\hline 08-SB5-15-2590 (B) & 08-1672 & 0.014 & 0.267 & 53.7 & & & 1.87 & 0.022 & 0.041 & 99.5 \\
\hline anions $(\mathrm{mg} / \mathrm{Kg})$ & & $\mathbf{F}$ & $\mathrm{Cl}$ & $\mathrm{NO2}$ & $\mathrm{NO3}$ & SO4 & PO4 & $\mathrm{HCO} 2$ & C2O4 & \\
\hline 08-SB5-11-2542 (A) & $08-1530$ & $<100$ & 297 & $<100$ & 17100 & $<100$ & $<100$ & 51100 & & \\
\hline 08-SB5-11-2542 (B) & $08-1530$ & $<100$ & 296 & $<100$ & 17800 & $<100$ & $<100$ & 51500 & & \\
\hline 08-SB5-12-2553 (A) & $08-1531$ & $<100$ & 279 & $<100$ & 18900 & $<100$ & $<100$ & 49300 & & \\
\hline 08-SB5-12-2553 (B) & $08-1531$ & $<100$ & 283 & $<100$ & 19300 & $<100$ & $<100$ & 50300 & & \\
\hline 08-SB5-13-2565 (A) & 08-1532 & $<100$ & 280 & $<100$ & 21700 & 150 & $<100$ & 54600 & & \\
\hline 08-SB5-13-2565 (B) & 08-1532 & $<100$ & 279 & $<100$ & 21800 & 143 & $<100$ & 55100 & & \\
\hline 08-SB5-14-2576 (A) & $08-1533$ & $<100$ & 310 & $<100$ & 25400 & 214 & $<100$ & 62900 & & \\
\hline 08-SB5-14-2576 (B) & $08-1533$ & $<100$ & 308 & $<100$ & 24600 & 213 & $<100$ & 62000 & & \\
\hline $08-S B 5-15-2590(A)$ & 08-1672 & & 293 & $<100$ & 23200 & 2600 & & 50300 & 3610 & \\
\hline 08-SB5-15-2590 (B) & $08-1672$ & & 290 & $<100$ & 23100 & 2830 & & 50200 & 3340 & \\
\hline & & \multicolumn{4}{|c|}{ Weight \% Solids Calculations } & & & & & \\
\hline & & Empty & Crucible Wt + & Crucible Wt + & & & & Insoluble & Cruc Wt+ & Wt \% \\
\hline Sample & & Crucible wt & Wet Sample & Dry wt & Total Solids & Wet Wt & Dry Wt & Solids & Calcined & Calcined \\
\hline 08-SB5-11-2542 (A) & $08-1530$ & 43.9275 & 49.5838 & 46.6204 & $47.6 \%$ & 5.6563 & 2.693 & $36.9 \%$ & 46.1519 & $39.3 \%$ \\
\hline 08-SB5-11-2542 (B) & $08-1530$ & 43.9071 & 49.5504 & 46.5987 & $47.7 \%$ & 5.6433 & 2.692 & $37.1 \%$ & 46.1337 & $39.5 \%$ \\
\hline 08-SB5-12-2553 (A) & 08-1531 & 44.0028 & 50.0713 & 46.7724 & $45.6 \%$ & 6.0685 & 2.770 & $34.8 \%$ & 46.2697 & $37.4 \%$ \\
\hline 08-SB5-12-2553 (B) & $08-1531$ & 43.1834 & 49.368 & 46.0175 & $45.8 \%$ & 6.1846 & 2.834 & $35.3 \%$ & 45.4995 & $37.4 \%$ \\
\hline 08-SB5-13-2565 (A) & 08-1532 & 43.4687 & 49.9884 & 46.3119 & $43.6 \%$ & 6.5197 & 2.843 & $33.6 \%$ & 45.7496 & $35.0 \%$ \\
\hline 08-SB5-13-2565 (B) & 08-1532 & 43.7324 & 50.2239 & 46.576 & $43.8 \%$ & 6.4915 & 2.844 & $33.8 \%$ & 46.0146 & $35.2 \%$ \\
\hline 08-SB5-14-2576 (A) & 08-1533 & 43.9942 & 50.7963 & 47.2027 & $47.2 \%$ & 6.8021 & 3.209 & $37.0 \%$ & 46.5792 & $38.0 \%$ \\
\hline 08-SB5-14-2576 (B) & $08-1533$ & 44.5008 & 51.2906 & 47.7125 & $47.3 \%$ & 6.7898 & 3.212 & $37.1 \%$ & 47.0916 & $38.2 \%$ \\
\hline $08-S B 5-15-2590(A)$ & $08-1672$ & 43.9943 & 50.5615 & 47.0377 & $46.34 \%$ & 6.5672 & 3.043 & $35.47 \%$ & 46.4940 & $38.06 \%$ \\
\hline \multirow[t]{2}{*}{$08-S B 5-15-2590$ (B) } & $08-1672$ & 43.4679 & 50.1523 & 46.5500 & $46.11 \%$ & 6.6844 & 3.082 & $35.28 \%$ & 45.9944 & $37.80 \%$ \\
\hline & & Empty & Crucible Wt + & Crucible Wt + & & Soluble & & & & \\
\hline Sample & & Crucible wt & Wet Sample & Dry wt & Uncorr & Solids & & $\mathrm{pH}$ & Density & Waste Loading \\
\hline 08-SB5-11-2542 (A) & $08-1530$ & 42.9349 & 45.1831 & 43.3155 & $16.93 \%$ & $10.7 \%$ & & 6.80 & 1.391 & $37.4 \%$ \\
\hline 08-SB5-11-2542 (B) & $08-1530$ & 44.5089 & 46.7703 & 44.8899 & $16.85 \%$ & $10.6 \%$ & & & & \\
\hline $08-S B 5-12-2553(A)$ & $08-1531$ & 40.4459 & 42.7024 & 40.8218 & $16.66 \%$ & $10.9 \%$ & & 6.33 & 1.332 & $35.2 \%$ \\
\hline 08-SB5-12-2553 (B) & 08-1531 & 43.1671 & 45.4340 & 43.5369 & $16.31 \%$ & $10.6 \%$ & & & & \\
\hline 08-SB5-13-2565 (A) & 08-1532 & 42.9079 & 45.1610 & 43.2486 & $15.12 \%$ & $10.0 \%$ & & 4.71 & 1.328 & $37.1 \%$ \\
\hline 08-SB5-13-2565 (B) & 08-1532 & 44.1714 & 46.4307 & 44.5115 & $15.05 \%$ & $10.0 \%$ & & & & \\
\hline 08-SB5-14-2576 (A) & $08-1533$ & 42.0030 & 44.2573 & 42.3669 & $16.14 \%$ & $10.2 \%$ & & 4.41 & 1.369 & $36.3 \%$ \\
\hline 08-SB5-14-2576 (B) & $08-1533$ & 44.9357 & 47.1949 & 45.3029 & $16.25 \%$ & $10.2 \%$ & & & & \\
\hline $08-S B 5-15-2590(A)$ & $08-1672$ & 42.5096 & 43.6486 & 42.7015 & $16.85 \%$ & $10.87 \%$ & & 4.82 & 1.347 & $39.1 \%$ \\
\hline 08-SB5-15-2590 (B) & 08-1672 & 42.3659 & 43.5074 & 42.5569 & $16.73 \%$ & $10.83 \%$ & & & & \\
\hline
\end{tabular}




\begin{tabular}{|c|c|c|c|c|c|c|c|c|c|c|}
\hline \multicolumn{11}{|c|}{ Appendix A-4: Condensate Sample Results } \\
\hline \multicolumn{11}{|c|}{ Process Science Analytical Laboratory } \\
\hline \multicolumn{11}{|c|}{\begin{tabular}{|l|l} 
Customer: Dan Lambert & \\
\end{tabular}} \\
\hline \multicolumn{11}{|l|}{ Date: $7 / 22 / 08$} \\
\hline \multicolumn{11}{|c|}{ Sample ID: MWWT 08-SB5-7-2508, 9-2519, 8-2490, 10-2499 } \\
\hline \multicolumn{11}{|c|}{ Sample ID: FAVC 08-SB5-7-2509, 9-2520, 8-2491, 10-2500 } \\
\hline \multicolumn{11}{|c|}{\begin{tabular}{|l|l|l|l|} 
Lab ID: $08-1364-1371$ & & & \\
\end{tabular}} \\
\hline \multirow{2}{*}{\multicolumn{11}{|c|}{ MWWT anions (mg/L) }} \\
\hline & & & & & & & & & & \\
\hline Sample Number & PSAL\# & $\mathbf{F}$ & NO2 & NO3 & $\mathrm{HCO} 2$ & $\mathrm{SO4}$ & $\mathrm{PO4}$ & $\mathrm{Cl}$ & $\mathrm{pH}$ & Density \\
\hline 08-SB5-7-2508 (A) & 08-1364 & $<100$ & $<100$ & 181 & $<100$ & $<100$ & $<100$ & $<100$ & 10.1 & 1.02 \\
\hline 08-SB5-7-2508 (B) & 08-1364 & $<100$ & $<100$ & 183 & $<100$ & $<100$ & $<100$ & $<100$ & & \\
\hline $08-S B 5-8-2490(A)$ & $08-1366$ & $<100$ & $<100$ & $<100$ & 440 & $<100$ & $<100$ & $<100$ & 3.07 & 1.02 \\
\hline $08-S B 5-8-2490(B)$ & $08-1366$ & $<100$ & $<100$ & $<100$ & 445 & $<100$ & $<100$ & $<100$ & & \\
\hline $08-S B 5-9-2519$ (A) & $08-1365$ & $<100$ & $<100$ & $<100$ & 1120 & $<100$ & $<100$ & $<100$ & 2.80 & 1.01 \\
\hline 08-SB5-9-2519 (B) & $08-1365$ & $<100$ & $<100$ & $<100$ & 1170 & $<100$ & $<100$ & $<100$ & & \\
\hline 08-SB5-10-2499 (A) & $08-1367$ & $<100$ & $<100$ & 114 & 15900 & $<100$ & $<100$ & $<100$ & 2.68 & 1.02 \\
\hline 08-SB5-10-2499 (B) & $08-1367$ & $<100$ & $<100$ & 116 & 16200 & $<100$ & $<100$ & $<100$ & & \\
\hline \multicolumn{11}{|l|}{ FAVC anions (mg/L) } \\
\hline Sample Number & PSAL\# & $\mathbf{F}$ & $\mathrm{NO2}$ & NO3 & $\mathrm{HCO} 2$ & SO4 & $\mathrm{PO4}$ & $\mathrm{Cl}$ & $\mathrm{pH}$ & Density \\
\hline 08-SB5-7-2509 (A) & $08-1368$ & $<100$ & $<100$ & 152000 & 527 & $<100$ & $<100$ & $<100$ & $<1.00$ & 1.09 \\
\hline 08-SB5-7-2509 (B) & $08-1368$ & $<100$ & $<100$ & 153000 & 518 & $<100$ & $<100$ & $<100$ & & \\
\hline 08-SB5-8-2491 (A) & $08-1370$ & $<100$ & $<100$ & 284000 & 844 & $<100$ & $<100$ & $<100$ & 2.37 & 1.12 \\
\hline 08-SB5-8-2491 (B) & $08-1370$ & $<100$ & $<100$ & 277000 & 841 & $<100$ & $<100$ & $<100$ & & \\
\hline 08-SB5-9-2520 (A) & $08-1369$ & $<100$ & $<100$ & 227000 & 1210 & $<100$ & $<100$ & $<100$ & 2.41 & 1.11 \\
\hline 08-SB5-9-2520 (B) & $08-1369$ & $<100$ & $<100$ & 231000 & 1220 & $<100$ & $<100$ & $<100$ & & \\
\hline 08-SB5-10-2500 (A) & $08-1371$ & $<100$ & 209 & 223000 & 1010 & $<100$ & $<100$ & $<100$ & 2.62 & 1.13 \\
\hline 08-SB5-10-2500 (B) & $08-1371$ & $<100$ & 208 & 220000 & 1020 & $<100$ & $<100$ & $<100$ & & \\
\hline & & & & & & & & & & \\
\hline & & & & & & & & & & \\
\hline \multicolumn{11}{|c|}{ Process Science Analytical Laboratory } \\
\hline \multicolumn{11}{|l|}{ Customer: Dan Lambert } \\
\hline \multicolumn{11}{|l|}{ Date: $7 / 23 / 08$} \\
\hline \multicolumn{11}{|c|}{ Sample ID: Dewater 08-SB5-7-2510, 9-2521, 8-2494, 10-2503 } \\
\hline \multicolumn{11}{|l|}{ Lab ID: 08-1360-1363 } \\
\hline & & & & & & & & & & \\
\hline \multicolumn{11}{|l|}{ Dewater anions ( $\mathrm{mg} / \mathrm{L})$} \\
\hline Sample Number & PSAL\# & $F$ & $\mathrm{NO2}$ & NO3 & $\mathrm{HCO} 2$ & SO4 & $\mathrm{PO4}$ & $\mathrm{Cl}$ & $\mathrm{pH}$ & Density \\
\hline 08-SB5-7-2510 (A) & $08-1360$ & $<100$ & $<100$ & 1580 & 985 & $<100$ & $<100$ & $<100$ & 1.94 & 1.01 \\
\hline $08-S B 5-7-2510$ (B) & $08-1360$ & $<100$ & $<100$ & 1620 & 1040 & $<100$ & $<100$ & $<100$ & & \\
\hline 08-SB5-8-2494 (A) & $08-1362$ & $<100$ & $<100$ & 1290 & 3520 & $<100$ & $<100$ & $<100$ & 1.98 & 1.02 \\
\hline 08-SB5-8-2494 (B) & $08-1362$ & $<100$ & $<100$ & 1310 & 3440 & $<100$ & $<100$ & $<100$ & & \\
\hline $08-S B 5-9-2521$ (A) & $08-1361$ & $<100$ & $<100$ & 485 & 7020 & $<100$ & $<100$ & $<100$ & 2.23 & 1.01 \\
\hline 08-SB5-9-2521 (B) & $08-1361$ & $<100$ & $<100$ & 491 & 7090 & $<100$ & $<100$ & $<100$ & & \\
\hline 08-SB5-10-2503 (A) & $08-1363$ & $<100$ & $<100$ & 330 & 9780 & $<100$ & $<100$ & $<100$ & 2.23 & 1.02 \\
\hline 08-SB5-10-2503 (B) & $08-1363$ & $<100$ & $<100$ & 330 & 9900 & $<100$ & $<100$ & $<100$ & & \\
\hline
\end{tabular}




\begin{tabular}{|c|c|c|c|c|c|c|c|c|c|c|}
\hline \multicolumn{11}{|c|}{ Appendix A-4: Condensate Sample Results } \\
\hline \multicolumn{11}{|c|}{ Process Science Analytical Laboratory } \\
\hline \multicolumn{11}{|c|}{ Customer: David Koopman, Dan Lambert } \\
\hline \multicolumn{11}{|l|}{ Date: $7 / 30 / 08$} \\
\hline \multicolumn{11}{|c|}{ Sample ID: 08-SB5-15-2587, 2588, 2589} \\
\hline \multicolumn{11}{|c|}{\begin{tabular}{|l|l|l|} 
Lab ID: 08-1668-1670 & & \\
\end{tabular}} \\
\hline & & & & & & & & & & \\
\hline \multirow{2}{*}{\multicolumn{11}{|c|}{ MWWT anions (mg/L) }} \\
\hline & & & & & & & & & & \\
\hline Sample Number & PSAL\# & $\mathbf{F}$ & $\mathrm{NO2}$ & $\mathrm{NO3}$ & $\mathrm{HCO} 2$ & SO4 & PO4 & $\mathrm{Cl}$ & $\mathrm{pH}$ & Density \\
\hline 08-SB5-11-2537 & $08-2040$ & $<100$ & $<100$ & 9160 & $<100$ & $<100$ & $<100$ & $<100$ & 9.38 & 1.02 \\
\hline 08-SB5-11-2537 & $08-2040$ & $<100$ & $<100$ & 9250 & $<100$ & $<100$ & $<100$ & $<100$ & & \\
\hline 08-SB5-12-2548 & $08-2041$ & $<100$ & $<100$ & $<100$ & $<100$ & $<100$ & $<100$ & $<100$ & 9.16 & 1.02 \\
\hline 08-SB5-12-2548 & 08-2041 & $<100$ & $<100$ & $<100$ & $<100$ & $<100$ & $<100$ & $<100$ & & \\
\hline 08-SB5-13-2560 & $08-2042$ & $<100$ & $<100$ & $<100$ & 948 & $<100$ & $<100$ & $<100$ & 2.42 & 1.02 \\
\hline 08-SB5-13-2560 & $08-2042$ & $<100$ & $<100$ & $<100$ & 1020 & $<100$ & $<100$ & $<100$ & & \\
\hline 08-SB5-14-2571 & $08-2043$ & $<100$ & $<100$ & $<100$ & 1450 & $<100$ & $<100$ & $<100$ & 2.30 & 1.02 \\
\hline 08-SB5-14-2571 & $08-2043$ & $<100$ & $<100$ & $<100$ & 1520 & $<100$ & $<100$ & $<100$ & & \\
\hline 08-SB5-15-2588 (A) & $08-1669$ & $<100$ & $<100$ & $<100$ & 1680 & $<100$ & 775 & $<100$ & 1.25 & \\
\hline 08-SB5-15-2588 (B) & 08-1669 & $<100$ & $<100$ & $<100$ & 1660 & $<100$ & 766 & $<100$ & & \\
\hline \multicolumn{11}{|l|}{ FAVC anions (mg/L) } \\
\hline Sample Number & PSAL\# & $\underline{F}$ & $\mathrm{NO2}$ & NO3 & $\mathrm{HCO} 2$ & SO4 & $\mathrm{PO4}$ & $\underline{\mathrm{Cl}}$ & $\mathrm{pH}$ & Density \\
\hline 08-SB5-11-2544 & $08-2044$ & $<100$ & 119 & 209000 & $<100$ & $<100$ & $<100$ & $<100$ & $<1.00$ & 1.10 \\
\hline 08-SB5-11-2544 & $08-2044$ & $<100$ & 117 & 210000 & $<100$ & $<100$ & $<100$ & $<100$ & & \\
\hline 08-SB5-12-2555 & $08-2045$ & $<100$ & $<100$ & 169000 & 1100 & $<100$ & $<100$ & $<100$ & $<1.00$ & 1.09 \\
\hline 08-SB5-12-2555 & $08-2045$ & $<100$ & $<100$ & 169000 & 1060 & $<100$ & $<100$ & $<100$ & & \\
\hline 08-SB5-13-2567 & $08-2046$ & $<100$ & $<100$ & 175000 & 1600 & $<100$ & $<100$ & $<100$ & $<1.00$ & 1.10 \\
\hline 08-SB5-13-2567 & $08-2046$ & $<100$ & $<100$ & 176000 & 1610 & $<100$ & $<100$ & $<100$ & & \\
\hline 08-SB5-14-2578 & $08-2047$ & $<100$ & 175 & 150000 & 179 & $<100$ & $<100$ & $<100$ & $<1.00$ & 1.07 \\
\hline 08-SB5-14-2578 & $08-2047$ & $<100$ & 166 & 154000 & 176 & $<100$ & $<100$ & $<100$ & & \\
\hline 08-SB5-15-2589 (A) & $08-1670$ & $<100$ & $<100$ & $<100$ & 163000 & $<100$ & 677 & $<100$ & 2.46 & \\
\hline 08-SB5-15-2589 (B) & $08-1670$ & $<100$ & $<100$ & $<100$ & 165000 & $<100$ & 636 & $<100$ & & \\
\hline & & & & & & & & & & \\
\hline \multicolumn{11}{|c|}{ Process Science Analytical Laboratory } \\
\hline \multicolumn{11}{|l|}{ Customer: Dan Lambert } \\
\hline \multicolumn{11}{|l|}{\begin{tabular}{|l|l} 
Date: $7 / 23 / 08$ & \\
\end{tabular}} \\
\hline \multicolumn{11}{|c|}{ Sample ID: SRAT Dewater 08-SB5-11-2538, 12-2549, 13-2561, 14-2572 } \\
\hline \multicolumn{11}{|c|}{ Sample ID: SME Dewater 08-SB5-11-2540, 12-2551, 13-2563, 14-2574 } \\
\hline Lab ID: 08-1555-1562 & & & & & & & & & & \\
\hline SRAT Dewater anions & $m g / L)$ & & & & & & & & & \\
\hline Sample Number & PSAL\# & $\underline{F}$ & NO2 & NO3 & $\mathrm{HCO2}$ & SO4 & PO4 & $\underline{\mathrm{Cl}}$ & $\mathrm{pH}$ & Density \\
\hline 08-SB5-11-2538 (A) & 08-1555 & $<\overline{100}$ & $<100$ & $\overline{1640}$ & 170 & $<100$ & $<100$ & $<\overline{100}$ & 1.83 & 1.02 \\
\hline 08-SB5-11-2538 (B) & 08-1555 & $<100$ & $<100$ & 1720 & 171 & $<100$ & $<100$ & $<100$ & & \\
\hline 08-SB5-12-2549 (A) & $08-1556$ & $<100$ & $<100$ & 1400 & 1740 & $<100$ & $<100$ & $<100$ & 1.92 & 1.03 \\
\hline 08-SB5-12-2549 (B) & $08-1556$ & $<100$ & $<100$ & 1420 & 1770 & $<100$ & $<100$ & $<100$ & & \\
\hline 08-SB5-13-2561(A) & $08-1557$ & $<100$ & $<100$ & 626 & 4510 & $<100$ & $<100$ & $<100$ & 2.17 & 1.02 \\
\hline 08-SB5-13-2561 (B) & $08-1557$ & $<100$ & $<100$ & 626 & 4600 & $<100$ & $<100$ & $<100$ & & \\
\hline 08-SB5-13-2561 & $08-2070$ & $<100$ & $<100$ & 604 & 3460 & $<100$ & $<100$ & $<100$ & 1.87 & 1.02 \\
\hline 08-SB5-13-2561 & $08-2070$ & $<100$ & $<100$ & 603 & 3560 & $<100$ & $<100$ & $<100$ & & \\
\hline 08-SB5-14-2572 (A) & $08-1558$ & $<100$ & $<100$ & 491 & 7490 & $<100$ & $<100$ & $<100$ & 2.19 & 1.02 \\
\hline 08-SB5-14-2572 (B) & $08-1558$ & $<100$ & $<100$ & 495 & 7440 & $<100$ & $<100$ & $<100$ & & \\
\hline 08-SB5-15-2587 (A) & $08-1668$ & $<100$ & $<100$ & $<100$ & 100 & $<100$ & 783 & $<100$ & & 2.36 \\
\hline 08-SB5-15-2587 (B) & $08-1668$ & $<100$ & $<100$ & $<100$ & 101 & $<100$ & 834 & $<100$ & & \\
\hline SME Dewater anions (1 & $g / L)$ & & & & & & & & & \\
\hline 08-SB5-11-2540 (A) & 08-1559 & $<100$ & $<100$ & $<100$ & $<100$ & $<100$ & $<100$ & $<100$ & 9.26 & 1.01 \\
\hline 08-SB5-11-2540 (B) & $08-1559$ & $<100$ & $<100$ & $<100$ & $<100$ & $<100$ & $<100$ & $<100$ & & \\
\hline 08-SB5-12-2551 (A) & $08-1560$ & $<100$ & $<100$ & $<100$ & 108 & $<100$ & $<100$ & $<100$ & 4.39 & 1.01 \\
\hline 08-SB5-12-2551(B) & $08-1560$ & $<100$ & $<100$ & $<100$ & 102 & $<100$ & $<100$ & $<100$ & & \\
\hline 08-SB5-13-2563 (A) & $08-1561$ & $<100$ & $<100$ & $<100$ & 2090 & $<100$ & $<100$ & $<100$ & 2.62 & 1.01 \\
\hline 08-SB5-13-2563 (B) & $08-1561$ & $<100$ & $<100$ & $<100$ & 2130 & $<100$ & $<100$ & $<100$ & & \\
\hline 08-SB5-14-2574 (A) & 08-1562 & $<100$ & $<100$ & $<100$ & 3310 & $<100$ & $<100$ & $<100$ & 2.49 & 1.01 \\
\hline 08-SB5-14-2574 (B) & $08-1562$ & $<100$ & $<100$ & $<100$ & 3330 & $<100$ & $<100$ & $<100$ & & \\
\hline
\end{tabular}




\begin{tabular}{|c|c|c|c|c|}
\hline \multicolumn{5}{|c|}{ Appendix A-5: Formate and Nitrate Balance } \\
\hline Run Number & SB5-7 & SB5-8 & SB5-9 & SB5-10 \\
\hline Sludge Simulant & SB5-D & SB5-D & SB5-D & SB5-D \\
\hline Acid Stoichiometry & 115 & 130 & 145 & 160 \\
\hline Fresh Sludge Mass, g & $3,017.89$ & $3,017.89$ & $3,017.89$ & $3,017.89$ \\
\hline ARP Slurry Added, g & 0.00 & 0.00 & 0.00 & 0.00 \\
\hline Fresh Sludge Nitrite, mg/kg & 10388 & 10388 & 10388 & 10388 \\
\hline Fresh Sludge Nitrate, mg/kg & 7114 & 7114 & 7114 & 7114 \\
\hline Nitric Added, mL & 33.08 & 36.78 & 32.26 & 37.37 \\
\hline Nitric Acid Molarity & 10.53 & 10.53 & 10.53 & 10.53 \\
\hline Formic Added, mL & 32.87 & 41.51 & 39.76 & 43.14 \\
\hline Formic Acid Molarity & 23.60 & 23.60 & 23.60 & 23.60 \\
\hline SRAT Product, g & $2,377.52$ & $2,688.70$ & $2,645.42$ & $2,771.29$ \\
\hline SRAT Product Nitrite, mg/kg & 62,200 & 64,750 & 71,700 & 72,450 \\
\hline SRAT Product Nitrate, $\mathrm{mg} / \mathrm{kg}$ & 0 & 0 & 0 & 0 \\
\hline SRAT Product Formate, $\mathrm{mg} / \mathrm{kg}$ & 29,550 & 29,750 & 34,850 & 36,200 \\
\hline \multicolumn{5}{|l|}{ Calculations } \\
\hline \multicolumn{5}{|l|}{ SRAT Data } \\
\hline Formate Added, g & 197.61 & 226.37 & 249.21 & 272.50 \\
\hline Nitrate Added, g & 48.55 & 59.29 & 69.44 & 80.08 \\
\hline Nitrite in Feed, g & 31.35 & 31.35 & 31.35 & 31.35 \\
\hline Nitrate in Feed, g & 21.73 & 21.73 & 21.73 & 21.73 \\
\hline Nitrite in SRAT product (grams) & 0.00 & 0.00 & 0.00 & 0.00 \\
\hline Nitrate in SRAT product (grams) & 70.26 & 73.99 & 92.19 & 100.32 \\
\hline Formate in SRAT product (grams) & 147.88 & 161.04 & 189.68 & 200.78 \\
\hline SRAT Formate Destruction, g & 49.73 & 65.32 & 59.54 & 71.72 \\
\hline SRAT Nitrite Destruction (grams) & 31.35 & 31.35 & 31.35 & 31.35 \\
\hline Nitrite to Nitrate Conversion, g & -0.02 & $\begin{array}{ll}-7.03 \\
\end{array}$ & 1.03 & -1.49 \\
\hline Nitrate from nitrite in SRAT product, mol & 0.00 & -0.11 & 0.02 & -0.02 \\
\hline Moles of nitrite reacted & 0.68 & 0.68 & 0.68 & 0.68 \\
\hline \% nitrite conversion to nitrate & -0.05 & -16.63 & 2.43 & -3.53 \\
\hline SRAT Nitrite Destruction (\%) & 100.00 & 100.00 & 100.00 & 100.00 \\
\hline SRAT Formate Destruction (\%) & 25.16 & 28.86 & 23.89 & 26.32 \\
\hline \multicolumn{5}{|l|}{ SME Data } \\
\hline Total SME Product, g & $2,313.94$ & $2,540.80$ & $2,533.12$ & $2,543.20$ \\
\hline SME Feed formate (grams) & 135.44 & 147.99 & 175.34 & 186.29 \\
\hline SME Feed nitrate (grams) & 64.35 & 68.00 & 85.22 & 93.08 \\
\hline SME Formate Added, g & 7.64 & 7.68 & 7.71 & 7.75 \\
\hline Nitrate in SME product (grams) & 55.53 & 64.28 & 74.60 & 82.65 \\
\hline Formate in SME product (grams) & 119.28 & 145.08 & 162.50 & 165.05 \\
\hline SME Formate Destruction (grams) & 23.80 & 10.59 & 20.55 & 28.99 \\
\hline SME Nitrate Destruction (grams) & 8.81 & 3.71 & 10.62 & 10.43 \\
\hline SME Nitrate Destruction (\%) & 13.69 & 5.46 & 12.46 & 11.20 \\
\hline SME Formate Destruction (\%) & 16.63 & 6.80 & 11.23 & 14.94 \\
\hline
\end{tabular}




\begin{tabular}{|c|c|c|c|c|c|}
\hline \multicolumn{6}{|c|}{ Appendix A-5: Formate and Nitrate Balance } \\
\hline Run Number & SB5-11 & SB5-12 & SB5-13 & SB5-14 & SB5-15 \\
\hline Sludge Simulant & SB5-C & SB5-C & SB5-C & SB5-C & SB5-C \\
\hline Acid Stoichiometry & 115 & 130 & 145 & 160 & 130 \\
\hline Fresh Sludge Mass, g & $3,500.00$ & $3,500.00$ & $3,500.00$ & $3,500.00$ & $2,450.00$ \\
\hline ARP Slurry Added, g & 0.00 & 0.00 & 0.00 & 0.00 & 971.00 \\
\hline Fresh Sludge Nitrite, mg/kg & 6,175 & 6,175 & 6,175 & 6,175 & 6,175 \\
\hline Fresh Sludge Nitrate, mg/kg & 3,940 & 3,940 & 3,940 & 3,940 & 3,940 \\
\hline Nitric Added, $\mathrm{mL}$ & 31.02 & 38.84 & 30.49 & 37.70 & 0.00 \\
\hline Nitric Acid Molarity & 10.53 & 10.53 & 10.53 & 10.53 & 10.53 \\
\hline \begin{tabular}{|l} 
Formic Added, mL \\
\end{tabular} & 34.73 & 45.08 & 35.05 & 40.93 & 0.00 \\
\hline Formic Acid Molarity & 23.60 & 23.60 & 23.60 & 23.60 & 23.60 \\
\hline SRAT Product, g & $1,960.00$ & $2,150.00$ & $2,180.00$ & $2,424.90$ & $2,200.00$ \\
\hline SRAT Product Nitrite, $\mathrm{mg} / \mathrm{kg}$ & 62,250 & 58,200 & 61,700 & 74,400 & 57,200 \\
\hline SRAT Product Nitrate, mg/kg & 0 & 0 & 0 & 0 & 0 \\
\hline SRAT Product Formate, $\mathrm{mg} / \mathrm{kg}$ & 20,600 & 23,600 & 26,150 & 28,600 & 27,950 \\
\hline \multicolumn{6}{|l|}{ Calculations } \\
\hline \multicolumn{6}{|l|}{ SRAT Data } \\
\hline Formate Added, $\mathrm{g}$ & 161.26 & 176.44 & 193.28 & 213.49 & 148.82 \\
\hline Nitrate Added, g & 31.09 & 44.67 & 52.13 & 59.34 & 31.38 \\
\hline Nitrite in Feed, g & 21.62 & 21.62 & 21.62 & 21.62 & 16.71 \\
\hline Nitrate in Feed, $\mathrm{g}$ & 14.03 & 14.03 & 14.03 & 14.03 & 26.80 \\
\hline Nitrite in SRAT product (grams) & 0.00 & 0.00 & 0.00 & 0.00 & 0.00 \\
\hline Nitrate in SRAT product (grams) & 40.38 & 50.74 & 57.01 & 69.35 & 61.49 \\
\hline Formate in SRAT product (grams) & 122.01 & 125.13 & 134.51 & 180.41 & 125.84 \\
\hline SRAT Formate Destruction, g & 39.25 & 51.31 & 58.78 & 33.07 & 22.98 \\
\hline SRAT Nitrite Destruction (grams) & 21.62 & 21.62 & 21.62 & 21.62 & 16.71 \\
\hline Nitrite to Nitrate Conversion, g & -4.74 & -7.96 & -9.16 & -4.03 & 3.31 \\
\hline Nitrate from nitrite in SRAT product, mol & -0.08 & -0.13 & -0.15 & -0.06 & 0.05 \\
\hline Moles of nitrite reacted & 0.47 & 0.47 & 0.47 & 0.47 & 0.36 \\
\hline \begin{tabular}{|l|}
$\%$ nitrite conversion to nitrate \\
\end{tabular} & -16.28 & -27.32 & -31.42 & -13.81 & 14.69 \\
\hline \begin{tabular}{|l} 
SRAT Nitrite Destruction (\%) \\
\end{tabular} & 100.00 & 100.00 & 100.00 & 100.00 & 100.00 \\
\hline SRAT Formate Destruction (\%) & 24.34 & 29.08 & 30.41 & 15.49 & 15.44 \\
\hline \multicolumn{6}{|l|}{ SME Data } \\
\hline Total SME Product, g & $2,146.70$ & $2,303.80$ & $2,319.00$ & $2,001.00$ & $2,088.00$ \\
\hline SME Feed formate (grams) & 109.48 & 113.47 & 123.33 & 165.47 & 111.01 \\
\hline SME Feed nitrate (grams) & 36.23 & 46.01 & 52.27 & 63.61 & 54.25 \\
\hline SME Formate Added, $\mathrm{g}$ & 7.40 & 7.45 & 7.48 & 7.50 & 7.01 \\
\hline Nitrate in SME product (grams) & 37.46 & 44.00 & 50.44 & 50.03 & 48.34 \\
\hline Formate in SME product (grams) & 110.13 & 114.73 & 127.20 & 124.96 & 104.92 \\
\hline SME Formate Destruction (grams) & 6.75 & 6.19 & 3.62 & 48.01 & 13.10 \\
\hline SME Nitrate Destruction (grams) & -1.23 & 2.01 & 1.83 & 13.58 & 5.91 \\
\hline SME Nitrate Destruction (\%) & -3.40 & 4.37 & 3.51 & 21.36 & 10.89 \\
\hline SME Formate Destruction (\%) & 5.78 & 5.12 & 2.77 & 27.76 & 11.10 \\
\hline
\end{tabular}


Appendix A-6: SRAT \& SME Cycle Run Data

\begin{tabular}{|c|c|c|c|c|}
\hline Run Number & SB5-7 & SB5-8 & SB5-9 & SB5-10 \\
\hline Sludge Simulant & SB5-D & SB5-D & SB5-D & SB5-D \\
\hline Acid Stoichiometry & 115 & 130 & 145 & 160 \\
\hline GC Calibration Gas & $\mathrm{K} 027610 \mathrm{H}$ & 0 & KP02454H & 0 \\
\hline Pre-Run Leak Check In & 90 & 90 & 90 & 90 \\
\hline Pre-Run Leak Check Out & 90.8 & 89.6 & 89.7 & 90 \\
\hline Post-Run Leak Check In & 90 & 90 & 0 & 90 \\
\hline Post-Run Leak Check Out & 90.2 & 0 & 0 & 90.8 \\
\hline pH Pre-Run Cal: Buffer 4 & 4.01 & 4.01 & 4.01 & 4 \\
\hline pH Pre-Run Cal: Buffer 10 & 10.02 & 10 & 10 & 10 \\
\hline pH Pre-Run Cal: Buffer 7 & 7.04 & 7.1 & 7.06 & 6.97 \\
\hline pH Post-Run Cal: Buffer 4 & 6.11 & NA & 0 & 0 \\
\hline pH Post-Run Cal: Buffer 10 & 10.23 & NA & 0 & 7.2 \\
\hline pH Post-Run Cal: Buffer 7 & 8.52 & $\mathrm{NA}$ & 0 & 0 \\
\hline Air Purge, sccm & 787.5 & 787.5 & 787.5 & 787.5 \\
\hline He Purge, sccm & 3.939 & 3.939 & 3.939 & 3.939 \\
\hline MWWT Water Added, g & 41.7 & 43.433 & 48.3 & 42.364 \\
\hline MWWT Final Mass, g & 50.01 & 39.6 & 50.01 & 47.9 \\
\hline FAVC Final Mass, g & 33.83 & 33.64 & 33.83 & 29.82 \\
\hline \multicolumn{5}{|l|}{\begin{tabular}{|l|} 
Additions, $\mathrm{g}$ \\
\end{tabular}} \\
\hline Sludge Added & 3017.90 & 3018.00 & 3017.90 & 3017.89 \\
\hline \multicolumn{5}{|l|}{ ARP Added } \\
\hline NaNO3 & 17.89 & 17.8906 & 17.89 & 17.8908 \\
\hline AgNO3 & 0.0987 & 0.0984 & 0.0983 & 0.0988 \\
\hline $\mathrm{Pd}(\mathrm{NO} 3) 2 * \mathrm{H} 2 \mathrm{O}$ & 0.1389 & 0.1384 & 0.1381 & 0.1393 \\
\hline $\mathrm{Rh}(\mathrm{NO}) 3 * 2 \mathrm{H} 2 \mathrm{O}$ & 2.2213 & 2.2218 & 2.2211 & 2.2208 \\
\hline RuCl3 & 1.2188 & 1.2190 & 1.2184 & 1.2184 \\
\hline Flush Water & 50.0000 & 50.0400 & 50.0000 & 50.0500 \\
\hline $\mathrm{HgO}$ & 13.8032 & 13.8038 & 13.8033 & 13.8037 \\
\hline Antifoam prior to acid & 6.17 & 6.17 & 6.17 & 6.17 \\
\hline $\begin{array}{l}\text { Water with 1st antifoam } \\
\text { addition }\end{array}$ & 6.17 & 6.17 & 6.17 & 6.17 \\
\hline Additional Antifoam & 3.09 & 0 & 3.09 & 3.09 \\
\hline Water with addition antifoam & 3.09 & 0 & 3.09 & 3.09 \\
\hline Antifoam prior to boiling & 15.43 & 0 & 15.43 & 15.43 \\
\hline $\begin{array}{l}\text { Water with 2nd antifoam } \\
\text { addition }\end{array}$ & 15.43 & 0 & 15.43 & 15.43 \\
\hline Total Antifoam & 24.69 & 6.17 & 24.69 & 24.69 \\
\hline
\end{tabular}


Appendix A-6: SRAT \& SME Cycle Run Data

\begin{tabular}{|c|c|c|c|c|}
\hline Run Number & SB5-7 & SB5-8 & SB5-9 & SB5-10 \\
\hline Sludge Simulant & SB5-D & SB5-D & SB5-D & SB5-D \\
\hline Acid Stoichiometry & 115 & 130 & 145 & 160 \\
\hline Ratio: Formic to Total Acid & 0.85 & 0.84 & 0.83 & 0.82 \\
\hline Run \# & SB5-7 & SB5-8 & SB5-9 & SB5-10 \\
\hline Sludge Feed Batch \# & SB5-D & SB5-D & SB5-D & SB5-D \\
\hline SRAT Vessel Volume, L & 4.00 & 4.00 & 4.00 & 4.00 \\
\hline Fresh Sludge Weight \% Total & 15.09 & 15.09 & 15.09 & 15.09 \\
\hline Fresh Sludge Weight \% Calci & 11.25 & 11.25 & 11.25 & 11.25 \\
\hline Fresh Sludge Weight \% Insoll & 7.95 & 7.95 & 7.95 & 7.95 \\
\hline Fresh Sludge Density & 1.12 & 1.12 & 1.12 & 1.12 \\
\hline Fresh Sludge Manganese (\% & 4.64 & 4.64 & 4.64 & 4.64 \\
\hline Fresh Sludge Slurry TIC (trea & 2470.34 & 2470.34 & 2470.34 & 2470.34 \\
\hline Fresh Sludge Hydroxide (Bas & 0.91 & 0.91 & 0.91 & 0.91 \\
\hline Fresh Sludge Mercury (\% of 7 & 0.00 & 0.00 & 0.00 & 0.00 \\
\hline Fresh Sludge Supernate mang & 0.00 & 0.00 & 0.00 & 0.00 \\
\hline Fresh Sludge Supernate densi & 1.06 & 1.06 & 1.06 & 1.06 \\
\hline Conversion of Nitrite to Nitra & 25.00 & 25.00 & 25.00 & 25.00 \\
\hline Destruction of Nitrite in SRA & 100.00 & 100.00 & 100.00 & 100.00 \\
\hline Destruction of Formic acid ch & 15.00 & 15.00 & 15.00 & 15.00 \\
\hline Destruction of oxalate charged & 50.00 & 50.00 & 50.00 & 50.00 \\
\hline Percent Acid in Excess Stoich & 115.00 & 130.00 & 145.00 & 160.00 \\
\hline SRAT Product Target Solids & 25.00 & 25.00 & 25.00 & 25.00 \\
\hline
\end{tabular}


Appendix A-6: SRAT \& SME Cycle Run Data

\begin{tabular}{|c|c|c|c|c|}
\hline Run Number & SB5-7 & SB5-8 & SB5-9 & SB5-10 \\
\hline$\overline{\text { Sludge Simulant }}$ & SB5-D & SB5-D & SB5-D & SB5-D \\
\hline Acid Stoichiometry & 115 & 130 & 145 & 160 \\
\hline DWPF Nitric Acid addition R & 2.00 & 2.00 & 2.00 & 2.00 \\
\hline DWPF Formic Acid addition & 2.00 & 2.00 & 2.00 & 2.00 \\
\hline Mass of pure formic acid $(\mathrm{H}$ & 208.06 & 232.19 & 256.39 & 280.45 \\
\hline Mass of pure nitric acid (HN & 49.71 & 60.31 & 70.81 & 81.51 \\
\hline REDOX Target & 0.20 & 0.20 & 0.20 & 0.20 \\
\hline REDOX Equation (7 for $\mathrm{Mn}+$ & 7.00 & 7.00 & 7.00 & 7.00 \\
\hline Nitric acid density, $20^{\circ} \mathrm{C}$ & 1.31 & 1.31 & 1.31 & 1.31 \\
\hline Formic acid density, $20^{\circ} \mathrm{C}$ & 1.20 & 1.20 & 1.20 & 1.20 \\
\hline Nitric acid, wt \% & 50.55 & 50.55 & 50.55 & 50.55 \\
\hline Formic acid, wt \% & 90.16 & 90.16 & 90.16 & 90.16 \\
\hline Formic acid amount & 4.52 & 5.04 & 5.57 & 6.09 \\
\hline Nitric acid amount & 0.79 & 0.96 & 1.12 & 1.29 \\
\hline Total Stoichiometric Acid req & 4.62 & 4.62 & 4.62 & 4.62 \\
\hline Percent Acid in Excess Stoich & 115.00 & 130.00 & 145.00 & 160.00 \\
\hline Actual acid to add to SRAT & 5.31 & 6.00 & 6.69 & 7.39 \\
\hline Acid required in moles per lite & 1.96 & 2.22 & 2.48 & 2.73 \\
\hline Final sludge mass in SRAT af & 2342.46 & 2466.91 & 2591.21 & 2715.81 \\
\hline Mass of SRAT cycle samples & 200.00 & 200.00 & 200.00 & 200.00 \\
\hline Mass of treated sludge going & 2142.46 & 2266.91 & 2391.21 & 2515.81 \\
\hline SME sample ratio & 0.91 & 0.92 & 0.92 & 0.93 \\
\hline Calcined Solids going to SME & 311.85 & 313.31 & 314.64 & 315.85 \\
\hline
\end{tabular}


Appendix A-6: SRAT \& SME Cycle Run Data

\begin{tabular}{|c|c|c|c|c|}
\hline Run Number & SB5-7 & SB5-8 & SB5-9 & SB5-10 \\
\hline Sludge Simulant & SB5-D & SB5-D & SB5-D & SB5-D \\
\hline Acid Stoichiometry & 115 & 130 & 145 & 160 \\
\hline $99.5 \%$ of scaled air purge & 787.46 & 787.46 & 787.46 & 787.46 \\
\hline Helium purge rate at $0.5 \mathrm{vol} \%$ & 3.94 & 3.94 & 3.94 & 3.94 \\
\hline Scaled boil-up rate & 4.59 & 4.59 & 4.59 & 4.59 \\
\hline Required dewatering time at a & 225.67 & 208.18 & 190.70 & 173.20 \\
\hline \multicolumn{5}{|l|}{ SME Cycle } \\
\hline Frit type & 418.00 & 418.00 & 418.00 & 418.00 \\
\hline Destruction of Formic acid in & 7.00 & 7.00 & 7.00 & 7.00 \\
\hline Destruction of Nitrate in SME & 0.00 & 0.00 & 0.00 & 0.00 \\
\hline Assumed SME density & 1.45 & 1.45 & 1.45 & 1.45 \\
\hline Basis Antifoam Addition for & 100.00 & 100.00 & 100.00 & 100.00 \\
\hline Number of basis antifoam add & 4.00 & 4.00 & 4.00 & 4.00 \\
\hline Sludge Oxide Contribution in & 35.00 & 35.00 & 35.00 & 35.00 \\
\hline Frit Slurry Formic Acid Ratio & 1.50 & 1.50 & 1.50 & 1.50 \\
\hline Target SME Solids total Wt\% & 45.00 & 45.00 & 45.00 & 45.00 \\
\hline Number of frit additions in SN & 2.00 & 2.00 & 2.00 & 2.00 \\
\hline \# DWPF Canister decons sim! & 5.00 & 5.00 & 5.00 & 5.00 \\
\hline Volume of water per deconed & 1000.00 & 1000.00 & 1000.00 & 1000.00 \\
\hline SME scale factor (ADJUSTE & 8997.65 & 8955.48 & 8917.74 & 8883.65 \\
\hline 99.5\% scaled SME air purge & 231.72 & 232.81 & 233.80 & 234.70 \\
\hline Helium purge rate at $0.5 \mathrm{vol} \%$ & 1.16 & 1.16 & 1.17 & 1.17 \\
\hline Frit solids (total) & 579.14 & 581.87 & 584.33 & 586.58 \\
\hline
\end{tabular}


Appendix A-6: SRAT \& SME Cycle Run Data

\begin{tabular}{|c|c|c|c|c|}
\hline$\longdiv { \text { Run Number } }$ & SB5-7 & SB5-8 & SB5-9 & SB5-10 \\
\hline $\begin{array}{l}\text { Sludge Simulant } \\
\end{array}$ & SB5-D & SB5-D & SB5-D & SB5-D \\
\hline Acid Stoichiometry & 115 & 130 & 145 & 160 \\
\hline $90 \mathrm{wt} \%$ formic acid (correctio & 8.69 & 8.73 & 8.76 & 8.80 \\
\hline Water in frit slurry & 570.46 & 573.14 & 575.57 & 577.78 \\
\hline Number of equal SME frit slu & 2.00 & 2.00 & 2.00 & 2.00 \\
\hline Scaled SME boil-up rate & 4.20 & 4.22 & 4.24 & 4.25 \\
\hline Approximate time to remove & 68.93 & 68.93 & 68.93 & 68.93 \\
\hline Final solids content in SME & 1122.79 & 1156.68 & 1190.26 & 1223.70 \\
\hline Target SME solids total wt $\%$ & 45.00 & 45.00 & 45.00 & 45.00 \\
\hline Mass of water to boil off for $f$ & 230.80 & 282.91 & 335.30 & 388.09 \\
\hline Approximate time to reach so & 54.94 & 67.03 & 79.10 & 91.21 \\
\hline Predicted $\mathrm{Fe}+2 / \mathrm{Fe}$ total in gla & 0.20 & 0.22 & 0.20 & 0.19 \\
\hline Start Heatup & 6/10/08 6:10 & $6 / 3 / 087: 33$ & 6/11/08 8:05 & $6 / 3 / 08$ 6:50 \\
\hline Start Nitric Acid Addition & 6/10/08 8:49 & $6 / 3 / 088: 38$ & 6/11/08 9:06 & $6 / 3 / 087: 40$ \\
\hline Stop Nitric Acid Addition & 6/10/08 10:13 & 6/3/08 10:23 & 6/11/08 11:05 & 6/3/08 10:15 \\
\hline Nitric Acid Feed Time, min & 84.00 & 105.00 & 119.00 & 155.00 \\
\hline Start Formic Acid Addition & 6/10/08 10:30 & 6/3/08 10:43 & 6/11/08 11:35 & 6/3/08 10:43 \\
\hline Stop Formic Acid Addition & 6/10/08 14:01 & 6/3/08 14:35 & 6/11/08 15:55 & 6/3/08 15:16 \\
\hline Formic Acid Feed Time, min & 211.00 & 232.00 & 260.00 & 273.00 \\
\hline Boiling Begins & $6 / 10 / 086: 10$ & $1 / 0 / 000: 00$ & 6/11/08 16:30 & $6 / 3 / 08$ 15:40 \\
\hline Dewater Complete & 6/10/08 18:32 & 6/3/08 19:26 & 6/11/08 15:55 & 6/3/08 18:53 \\
\hline Dewater Time, min & 742.00 & 57028046.00 & 1405.00 & 193.00 \\
\hline Boiling Complete & $6 / 11 / 088: 40$ & 6/4/08 9:00 & 6/12/08 10:30 & 6/4/08 9:42 \\
\hline Total Boiling Time, min & 1590.00 & 57028860.00 & 1080.00 & 1082.00 \\
\hline Nitric Acid Feed Rate, mL/mi & 0.89 & 0.87 & 0.90 & 0.79 \\
\hline Formic Acid Feed Rate, $\mathrm{mL} / \mathrm{m}$ & 0.91 & 0.92 & 0.91 & 0.95 \\
\hline
\end{tabular}


Appendix A-6: SRAT \& SME Cycle Run Data

\begin{tabular}{|c|c|c|c|c|c|}
\hline Run Number & SB5-11 & SB5-12 & SB5-13 & SB5-14 & SB5-15 \\
\hline Sludge Simulant & SB5-C & SB5-C & SB5-C & SB5-C & SB5-C \\
\hline Acid Stoichiometry & 115 & 130 & 145 & 160 & 130 \\
\hline GC Calibration Gas & 0 & 0 & 0 & 0 & $\mathrm{~K} 027610 \mathrm{H}$ \\
\hline Pre-Run Leak Check In & 90 & 90 & 90 & 90 & 90 \\
\hline Pre-Run Leak Check Out & 92.2 & 91 & 98.1 & 88 & 83.5 \\
\hline Post-Run Leak Check In & 90 & 90 & 90 & 90 & 90 \\
\hline Post-Run Leak Check Out & 92 & 88.1 & 94.2 & 86.2 & 92.2 \\
\hline pH Pre-Run Cal: Buffer 4 & 4 & 4 & 4 & 4 & 4 \\
\hline pH Pre-Run Cal: Buffer 10 & 10 & 10 & 10 & 10 & 10 \\
\hline pH Pre-Run Cal: Buffer 7 & 7.07 & 7.02 & 7.02 & 7.02 & 6.99 \\
\hline pH Post-Run Cal: Buffer 4 & 7.12 & 4.49 & 4.47 & 4.79 & 4.49 \\
\hline pH Post-Run Cal: Buffer 10 & 7.46 & 10.31 & 9.94 & 3.83 & 10.32 \\
\hline pH Post-Run Cal: Buffer 7 & 7.14 & 7.31 & 7.38 & 0 & 7.77 \\
\hline Air Purge, sccm & 932.3 & 932.3 & 932.3 & 932.3 & 922.5 \\
\hline He Purge, sccm & 4.66 & 4.66 & 4.66 & 4.66 & 4.61 \\
\hline MWWT Water Added, g & 49.07 & 40.73 & 51 & 40.04 & 49.5 \\
\hline MWWT Final Mass, g & 51.97 & 41.84 & 54.31 & 42.23 & 49.31 \\
\hline FAVC Final Mass, $\mathrm{g}$ & 29.49 & 34.12 & 34.69 & 34.9 & 30.5 \\
\hline \multicolumn{6}{|l|}{ Additions, g } \\
\hline Sludge Added & 3500.50 & 3501.20 & 3501.20 & 3501.60 & $2,450.00$ \\
\hline ARP Added & & & & & 971.00 \\
\hline \multicolumn{6}{|l|}{ NaNO3 } \\
\hline AgNO3 & 0.0973 & 0.0973 & 0.0973 & 0.0973 & 0.0960 \\
\hline $\mathrm{Pd}(\mathrm{NO} 3) 2 * \mathrm{H} 2 \mathrm{O}$ & 0.1066 & 0.1065 & 0.1065 & 0.1064 & 0.1045 \\
\hline $\mathrm{Rh}(\mathrm{NO}) 3 * 2 \mathrm{H} 2 \mathrm{O}$ & 2.0661 & 2.0661 & 2.0662 & 2.0660 & 2.0264 \\
\hline RuCl3 & 1.0555 & 1.0555 & 1.0556 & 1.0554 & 1.0354 \\
\hline Flush Water & 50.0200 & 50.0100 & 50.0000 & 50.0000 & 50.0100 \\
\hline $\mathrm{HgO}$ & 11.5276 & 11.5276 & 11.5276 & 11.5275 & 8.1167 \\
\hline Antifoam prior to acid & 7.1300 & 7.1300 & 7.1300 & 7.1330 & 7.0500 \\
\hline $\begin{array}{l}\text { Water with 1st antifoam } \\
\text { addition }\end{array}$ & 7.1300 & 7.1300 & 7.1300 & 7.1300 & 7.0500 \\
\hline Additional Antifoam & 0.0000 & 3.5600 & 0.0000 & 3.5600 & 21.1600 \\
\hline Water with addition antifoam & 0.0000 & 3.5600 & 0.0000 & 3.5700 & 21.1400 \\
\hline Antifoam prior to boiling & 17.8200 & 17.8200 & 17.8200 & 17.8200 & 17.6200 \\
\hline $\begin{array}{l}\text { Water with 2nd antifoam } \\
\text { addition }\end{array}$ & 17.8200 & 17.8200 & 17.8200 & 17.8200 & 17.6200 \\
\hline Total Antifoam & 24.95 & 28.51 & 24.95 & 28.513 & 45.83 \\
\hline
\end{tabular}


Appendix A-6: SRAT \& SME Cycle Run Data

\begin{tabular}{|c|c|c|c|c|c|}
\hline Run Number & SB5-11 & SB5-12 & SB5-13 & SB5-14 & SB5-15 \\
\hline Sludge Simulant & SB5-C & SB5-C & SB5-C & SB5-C & SB5-C \\
\hline Acid Stoichiometry & 115 & 130 & 145 & 160 & 130 \\
\hline Ratio: Formic to Total Acid & 0.88 & 0.84 & 0.84 & 0.83 & 0.87 \\
\hline Run \# & SB5-11 & SB5-12 & SB5-13 & SB5-14 & SB5-15 \\
\hline Sludge Feed Batch \# & SB5-C & SB5-C & SB5-C & SB5-C & SB5-C \\
\hline SRAT Vessel Volume, L & 4.00 & 4.00 & 4.00 & 4.00 & 4.00 \\
\hline $\begin{array}{l}\text { Fresh Sludge Weight \% Total } \\
\text { Solids }\end{array}$ & 12.47 & 12.47 & 12.47 & 12.47 & 12.47 \\
\hline $\begin{array}{l}\text { Fresh Sludge Weight \% } \\
\text { Calcined Solids }\end{array}$ & 9.51 & 9.51 & 9.51 & 9.51 & 9.51 \\
\hline $\begin{array}{l}\text { Fresh Sludge Weight \% } \\
\text { Insoluble Solids }\end{array}$ & 7.85 & 7.85 & 7.85 & 7.85 & 7.85 \\
\hline Fresh Sludge Density & 1.09 & 1.09 & 1.09 & 1.09 & 1.09 \\
\hline $\begin{array}{l}\text { Fresh Sludge Manganese (\% } \\
\text { of Calcined Solids) }\end{array}$ & 5.05 & 5.05 & 5.05 & 5.05 & 5.05 \\
\hline \begin{tabular}{|l}
$\begin{array}{l}\text { Fresh Sludge Slurry TIC } \\
\text { (treated as Carbonate) }\end{array}$ \\
\end{tabular} & 1338.06 & 1338.06 & 1338.06 & 1338.06 & 1338.06 \\
\hline $\begin{array}{l}\text { Fresh Sludge Hydroxide } \\
\text { (Base Equivalents) } \mathrm{pH}=7\end{array}$ & 0.63 & 0.63 & 0.63 & 0.63 & 0.63 \\
\hline $\begin{array}{l}\text { Fresh Sludge Mercury (\% of } \\
\text { Total Solids in untrimmed } \\
\text { sludge) }\end{array}$ & 0.00 & 0.00 & 0.00 & 0.00 & 0.00 \\
\hline $\begin{array}{l}\text { Fresh Sludge Supernate } \\
\text { manganese }\end{array}$ & 0.00 & 0.00 & 0.00 & 0.00 & 0.00 \\
\hline $\begin{array}{l}\text { Fresh Sludge Supernate } \\
\text { density }\end{array}$ & 1.02 & 1.02 & 1.02 & 1.02 & 1.02 \\
\hline $\begin{array}{l}\text { Conversion of Nitrite to } \\
\text { Nitrate in SRAT Cycle }\end{array}$ & -16.30 & -27.30 & -31.40 & 0.00 & 14.70 \\
\hline $\begin{array}{l}\text { Destruction of Nitrite in } \\
\text { SRAT and SME cycle }\end{array}$ & 100.00 & 100.00 & 100.00 & 100.00 & 100.00 \\
\hline $\begin{array}{l}\text { Destruction of Formic acid } \\
\text { charged in SRAT }\end{array}$ & 24.30 & 29.10 & 30.40 & 25.00 & 15.40 \\
\hline $\begin{array}{l}\text { Destruction of oxalate } \\
\text { charged }\end{array}$ & 50.00 & 50.00 & 50.00 & 50.00 & 20.00 \\
\hline $\begin{array}{l}\text { Percent Acid in Excess } \\
\text { Stoichiometric Ratio }\end{array}$ & 115.00 & 130.00 & 145.00 & 160.00 & 130.00 \\
\hline SRAT Product Target Solids & 26.09 & 25.15 & 25.06 & 25.00 & 25.11 \\
\hline
\end{tabular}


Appendix A-6: SRAT \& SME Cycle Run Data

\begin{tabular}{|c|c|c|c|c|c|}
\hline Run Number & SB5-11 & SB5-12 & SB5-13 & SB5-14 & SB5-15 \\
\hline Sludge Simulant & SB5-C & SB5-C & SB5-C & SB5-C & SB5-C \\
\hline Acid Stoichiometry & 115 & 130 & 145 & 160 & 130 \\
\hline $\begin{array}{l}\text { DWPF Nitric Acid addition } \\
\text { Rate }\end{array}$ & 2.00 & 2.00 & 2.00 & 2.00 & 2.00 \\
\hline $\begin{array}{l}\text { DWPF Formic Acid addition } \\
\text { Rate }\end{array}$ & 2.00 & 2.00 & 2.00 & 2.00 & 2.00 \\
\hline $\begin{array}{l}\text { Mass of pure formic acid } \\
(\mathrm{HCOOH}) \text { added }\end{array}$ & 166.42 & 180.82 & 199.97 & 219.33 & 152.46 \\
\hline $\begin{array}{l}\text { Mass of pure nitric acid } \\
(\mathrm{HNO3}) \text { added }\end{array}$ & 31.66 & 45.79 & 53.42 & 60.76 & 32.18 \\
\hline REDOX Target & 0.20 & 0.20 & 0.20 & 0.20 & 0.20 \\
\hline $\begin{array}{l}\text { REDOX Equation (7 for } \\
M n+7 \text {, otherwise assumes } \\
M n+4)\end{array}$ & 7.00 & 7.00 & 7.00 & 7.00 & 7.00 \\
\hline Nitric acid density, $20^{\circ} \mathrm{C}$ & 1.31 & 1.31 & 1.31 & 1.31 & 1.31 \\
\hline Formic acid density, $20^{\circ} \mathrm{C}$ & 1.20 & 1.20 & 1.20 & 1.20 & 1.20 \\
\hline Nitric acid, wt \% & 50.55 & 50.55 & 50.55 & 50.55 & 50.55 \\
\hline Formic acid, wt \% & 90.16 & 90.16 & 90.16 & 90.16 & 90.16 \\
\hline Formic acid amount & 3.62 & 3.93 & 4.34 & 4.77 & 3.31 \\
\hline Nitric acid amount & 0.50 & 0.73 & 0.85 & 0.96 & 0.51 \\
\hline $\begin{array}{l}\text { Total Stoichiometric Acid } \\
\text { required }\end{array}$ & 3.58 & 3.58 & 3.58 & 3.58 & 2.94 \\
\hline $\begin{array}{l}\text { Percent Acid in Excess } \\
\text { Stoichiometric Ratio } \\
\end{array}$ & 115.00 & 130.00 & 145.00 & 160.00 & 130.00 \\
\hline Actual acid to add to SRAT & 4.12 & 4.66 & 5.19 & 5.73 & 3.82 \\
\hline $\begin{array}{l}\text { Acid required in moles per } \\
\text { liter of starting sludge (less } \\
\text { receipt samples) }\end{array}$ & 1.28 & 1.45 & 1.62 & 1.78 & 1.75 \\
\hline $\begin{array}{l}\text { Final sludge mass in SRAT } \\
\text { after acid addition and } \\
\text { dewater (neglecting samples) }\end{array}$ & 2013.96 & 2154.25 & 2236.05 & 2372.28 & 2159.80 \\
\hline $\begin{array}{l}\text { Mass of SRAT cycle samples } \\
\text { (excluding SRAT Receipt) }\end{array}$ & 201.27 & 200.00 & 181.10 & 200.00 & 259.21 \\
\hline $\begin{array}{l}\text { Mass of treated sludge going } \\
\text { into SME cycle }\end{array}$ & 1812.69 & 1954.25 & 2054.95 & 2172.28 & 1900.59 \\
\hline SME sample ratio & 0.90 & 0.91 & 0.92 & 0.92 & 0.88 \\
\hline $\begin{array}{l}\text { Calcined Solids going to } \\
\text { SME }\end{array}$ & 300.84 & 303.21 & 307.18 & 306.07 & 277.35 \\
\hline
\end{tabular}


Appendix A-6: SRAT \& SME Cycle Run Data

\begin{tabular}{|c|c|c|c|c|c|}
\hline Run Number & SB5-11 & SB5-12 & SB5-13 & SB5-14 & SB5-15 \\
\hline Sludge Simulant & SB5-C & SB5-C & SB5-C & SB5-C & SB5-C \\
\hline Acid Stoichiometry & 115 & 130 & 145 & 160 & 130 \\
\hline $99.5 \%$ of scaled air purge & 932.29 & 932.29 & 932.29 & 932.29 & 922.48 \\
\hline $\begin{array}{l}\text { Helium purge rate at } 0.5 \\
\text { vol\% }\end{array}$ & 4.66 & 4.66 & 4.66 & 4.66 & 4.61 \\
\hline Scaled boil-up rate & 5.44 & 5.44 & 5.44 & 5.44 & 5.38 \\
\hline $\begin{array}{l}\text { Required dewatering time at } \\
\text { above rate }\end{array}$ & 326.88 & 306.92 & 297.06 & 279.72 & 582.84 \\
\hline \multicolumn{6}{|l|}{ SME Cycle } \\
\hline \begin{tabular}{|l|} 
Frit type \\
\end{tabular} & 418.00 & 418.00 & 418.00 & 418.00 & 418.00 \\
\hline $\begin{array}{l}\text { Destruction of Formic acid } \\
\text { in SME }\end{array}$ & 5.80 & 5.10 & 2.80 & 7.00 & 11.10 \\
\hline $\begin{array}{l}\text { Destruction of Nitrate in } \\
\text { SME }\end{array}$ & -3.40 & 4.40 & 3.50 & 0.00 & 10.90 \\
\hline Assumed SME density & 1.45 & 1.45 & 1.45 & 1.45 & 1.45 \\
\hline $\begin{array}{l}\text { Basis Antifoam Addition for } \\
\text { SME cycle }\end{array}$ & 100.00 & 100.00 & 100.00 & 100.00 & 100.00 \\
\hline $\begin{array}{l}\text { Number of basis antifoam } \\
\text { additions added during SME } \\
\text { cycle }\end{array}$ & 4.00 & 4.00 & 4.00 & 4.00 & 4.00 \\
\hline $\begin{array}{l}\text { Sludge Oxide Contribution in } \\
\text { SME (Waste Loading) }\end{array}$ & 35.00 & 35.00 & 35.00 & 35.00 & 35.00 \\
\hline $\begin{array}{l}\text { Frit Slurry Formic Acid } \\
\text { Ratio }\end{array}$ & 1.50 & 1.50 & 1.50 & 1.50 & 1.50 \\
\hline $\begin{array}{l}\text { Target SME Solids total } \\
\mathrm{Wt} \%\end{array}$ & 45.00 & 45.00 & 45.00 & 45.00 & 45.00 \\
\hline $\begin{array}{l}\text { Number of frit additions in } \\
\text { SME Cycle }\end{array}$ & 2.00 & 2.00 & 2.00 & 2.00 & 2.00 \\
\hline $\begin{array}{l}\text { \# DWPF Canister decons } \\
\text { simulated }\end{array}$ & 0.00 & 0.00 & 0.00 & 0.00 & 0.00 \\
\hline $\begin{array}{l}\text { Volume of water per deconed } \\
\text { can }\end{array}$ & 1000.00 & 1000.00 & 1000.00 & 1000.00 & 1000.00 \\
\hline $\begin{array}{l}\text { SME scale factor } \\
\text { (ADJUSTED FOR SRAT } \\
\text { SAMPLES) }\end{array}$ & 7722.76 & 7662.34 & 7563.55 & 7590.94 & 7982.94 \\
\hline 99.5\% scaled SME air purge & 269.98 & 272.11 & 275.66 & 274.67 & 261.18 \\
\hline $\begin{array}{l}\text { Helium purge rate at } 0.5 \\
\text { vol\% }\end{array}$ & 1.35 & 1.36 & 1.38 & 1.37 & 1.31 \\
\hline Frit solids (total) & 558.71 & 563.11 & 570.47 & 568.41 & 531.25 \\
\hline
\end{tabular}


Appendix A-6: SRAT \& SME Cycle Run Data

\begin{tabular}{|c|c|c|c|c|c|}
\hline Run Number & SB5-11 & SB5-12 & SB5-13 & SB5-14 & SB5-15 \\
\hline $\begin{array}{l}\text { Sludge Simulant } \\
\end{array}$ & SB5-C & SB5-C & SB5-C & SB5-C & SB5-C \\
\hline Acid Stoichiometry & 115 & 130 & 145 & 160 & 130 \\
\hline $\begin{array}{l}90 \mathrm{wt} \% \text { formic acid } \\
\text { (corrections necessary for } \\
\text { other concentrations) }\end{array}$ & 8.38 & 8.45 & 8.56 & 8.53 & 7.97 \\
\hline Water in frit slurry & 550.33 & 554.67 & 561.91 & 559.88 & 523.28 \\
\hline $\begin{array}{l}\text { Number of equal SME frit } \\
\text { slurry additions }\end{array}$ & 2.00 & 2.00 & 2.00 & 2.00 & 2.00 \\
\hline Scaled SME boil-up rate & 4.89 & 4.93 & 5.00 & 4.98 & 4.73 \\
\hline $\begin{array}{l}\text { Approximate time to remove } \\
\text { water: }\end{array}$ & 57.07 & 57.07 & 57.07 & 57.07 & 56.10 \\
\hline Final solids content in SME & 1039.37 & 1062.41 & 1093.40 & 1119.37 & 1015.86 \\
\hline Target SME solids total wt\% & 45.00 & 45.00 & 45.00 & 45.00 & 45.00 \\
\hline $\begin{array}{l}\text { Mass of water to boil off for } \\
\text { final SME concentration }\end{array}$ & 65.32 & 160.35 & 199.75 & 257.55 & 256.10 \\
\hline $\begin{array}{l}\text { Approximate time to reach } \\
\text { solids target concentration. }\end{array}$ & 13.35 & 32.51 & 39.97 & 51.72 & 52.30 \\
\hline 0 & & & & & \\
\hline $\begin{array}{l}\text { Predicted Fe+2/Fe total in } \\
\text { glass (no SME cycle) }\end{array}$ & 0.29 & 0.23 & 0.23 & 0.28 & 0.18 \\
\hline Start Heatup & 7/10/08 18:15 & $7 / 9 / 086: 24$ & 7/9/08 18:10 & $7 / 8 / 086: 37$ & $7 / 23 / 086: 40$ \\
\hline Start Nitric Acid Addition & 7/10/08 20:03 & $7 / 9 / 087: 44$ & $7 / 9 / 08$ 19:10 & $7 / 8 / 08$ 8:00 & $7 / 23 / 087: 36$ \\
\hline Stop Nitric Acid Addition & $7 / 10 / 0820: 49$ & $7 / 9 / 088: 50$ & $7 / 9 / 0820: 27$ & $7 / 8 / 089: 25$ & $7 / 23 / 088: 14$ \\
\hline Nitric Acid Feed Time, min & 46.00 & 66.00 & 77.00 & 85.00 & 38.00 \\
\hline Start Formic Acid Addition & 7/10/08 21:16 & 7/9/08 8:57 & 7/9/08 20:42 & 7/8/08 9:44 & $7 / 23 / 088: 25$ \\
\hline Stop Formic Acid Addition & $7 / 10 / 08$ 23:40 & $7 / 9 / 0812: 20$ & 7/9/08 23:35 & $7 / 8 / 0812: 54$ & $7 / 23 / 0810: 38$ \\
\hline Formic Acid Feed Time, min & 144.00 & 203.00 & 173.00 & 190.00 & 133.00 \\
\hline Boiling Begins & 7/11/08 0:05 & $7 / 9 / 0812: 20$ & $7 / 9 / 0823: 57$ & 7/8/08 13:30 & 7/23/08 11:03 \\
\hline Dewater Complete & $7 / 11 / 085: 23$ & $7 / 9 / 0817: 11$ & $7 / 10 / 084: 44$ & $7 / 8 / 08$ 18:05 & 7/23/08 15:32 \\
\hline Dewater Time, min & 318.00 & 291.00 & 287.00 & 275.00 & 269.00 \\
\hline Boiling Complete & 7/11/08 18:05 & $7 / 10 / 08$ 6:23 & 7/10/08 17:52 & 7/9/08 9:01 & $7 / 24 / 080: 57$ \\
\hline Total Boiling Time, min & 1080.00 & 1083.00 & 1075.00 & 1171.00 & 834.00 \\
\hline $\begin{array}{l}\text { Nitric Acid Feed Rate, } \\
\mathrm{mL} / \mathrm{min}\end{array}$ & 1.04 & 1.05 & 1.05 & 1.08 & 1.06 \\
\hline $\begin{array}{l}\text { Formic Acid Feed Rate, } \\
\mathrm{mL} / \mathrm{min}\end{array}$ & 1.06 & 0.82 & 1.06 & 1.06 & 1.08 \\
\hline
\end{tabular}


Appendix A- 7. Mercury Results: SRAT Products

\begin{tabular}{|c|c|c|c|c|c|c|c|c|c|c|}
\hline Sample Id & User SampleID & LIMS Method & Element & Result & Units & Rv & $\begin{array}{l}\text { Sample } \\
\text { Mass, } \mathbf{g}\end{array}$ & $\begin{array}{c}\text { Digested } \\
\text { Volume, } \mathrm{mL}\end{array}$ & $\begin{array}{l}\text { Slurry Total } \\
\text { Solids, wt \% }\end{array}$ & $\mathrm{Hg}$, wt \% \\
\hline 300250088 & 08_SB5_7_2506 & CV Hg Digested & $\mathrm{Hg}$ & 8.1238 & $\mathrm{mg} / \mathrm{L}$ & 1 & 1.49 & 100 & 25.642 & 0.213 \\
\hline 300250089 & 08_SB5_8_2492 & CV Hg Digested & $\mathrm{Hg}$ & 9.6036 & $\mathrm{mg} / \mathrm{L}$ & 1 & 2.46 & 100 & 24.008 & 0.163 \\
\hline 300250090 & 08_SB5_9_2517 & CV Hg Digested & $\mathrm{Hg}$ & 1.2495 & $\mathrm{mg} / \mathrm{L}$ & 1 & 1.26 & 100 & 23.959 & 0.041 \\
\hline 300250091 & 08 SB5_10_2501 & CV Hg Digested & $\mathrm{Hg}$ & 2.9766 & $\mathrm{mg} / \mathrm{L}$ & 1 & 1.958 & 100 & 24.169 & 0.0629 \\
\hline 300250861 & 08 SB5 $11 \quad 2535$ & CV Hg Digested & $\mathrm{Hg}$ & 34.675 & $\mathrm{mg} / \mathrm{L}$ & 1 & 1.31 & 100 & 26.8998 & 0.984 \\
\hline 300250862 & 08_SB5_12_2546 & CV Hg Digested & $\mathrm{Hg}$ & \begin{tabular}{|l|}
46.414 \\
\end{tabular} & $\mathrm{mg} / \mathrm{L}$ & 1 & 1.961 & 100 & 25.5255 & 0.927 \\
\hline 300250863 & 08_SB5_13_2558 & CV Hg Digested & $\mathrm{Hg}$ & 3.7471 & \begin{tabular}{|l|}
$\mathrm{mg} / \mathrm{L}$ \\
\end{tabular} & 1 & 1 & 100 & 25.6747 & 0.146 \\
\hline 300250864 & 08_SB5_14_2569 & CV Hg Digested & $\mathrm{Hg}$ & 2.1279 & $\mathrm{mg} / \mathrm{L}$ & 1 & 1.5369 & 100 & 26.8056 & 0.0517 \\
\hline 300251641 & 08 SB5_15_2586 & $\mathrm{CV} \mathrm{Hg} \mathrm{Digested}$ & $\mathrm{Hg}$ & \begin{tabular}{|l|}
101.52 \\
\end{tabular} & \begin{tabular}{|l|}
$\mathrm{mg} / \mathrm{L}$ \\
\end{tabular} & $\frac{2}{1}$ & 47.2146 & 250 & 24.451 & 0.0415 \\
\hline
\end{tabular}




\section{Appendix B. Sample/Run Results: Graphical Presentations}

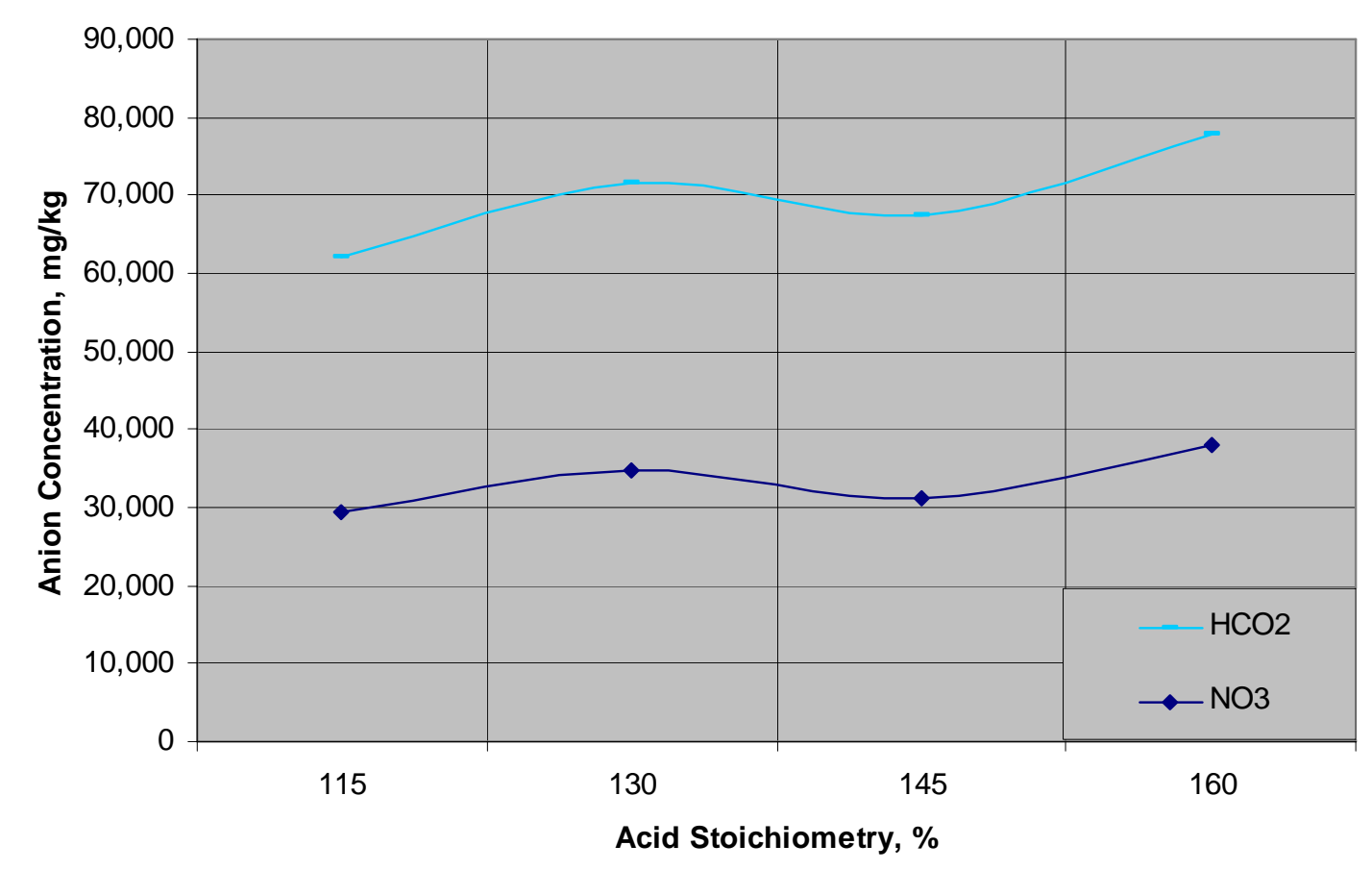

Figure B- 1c. Blend SRAT Product Nitrate and Formate versus Acid Stoichiometry

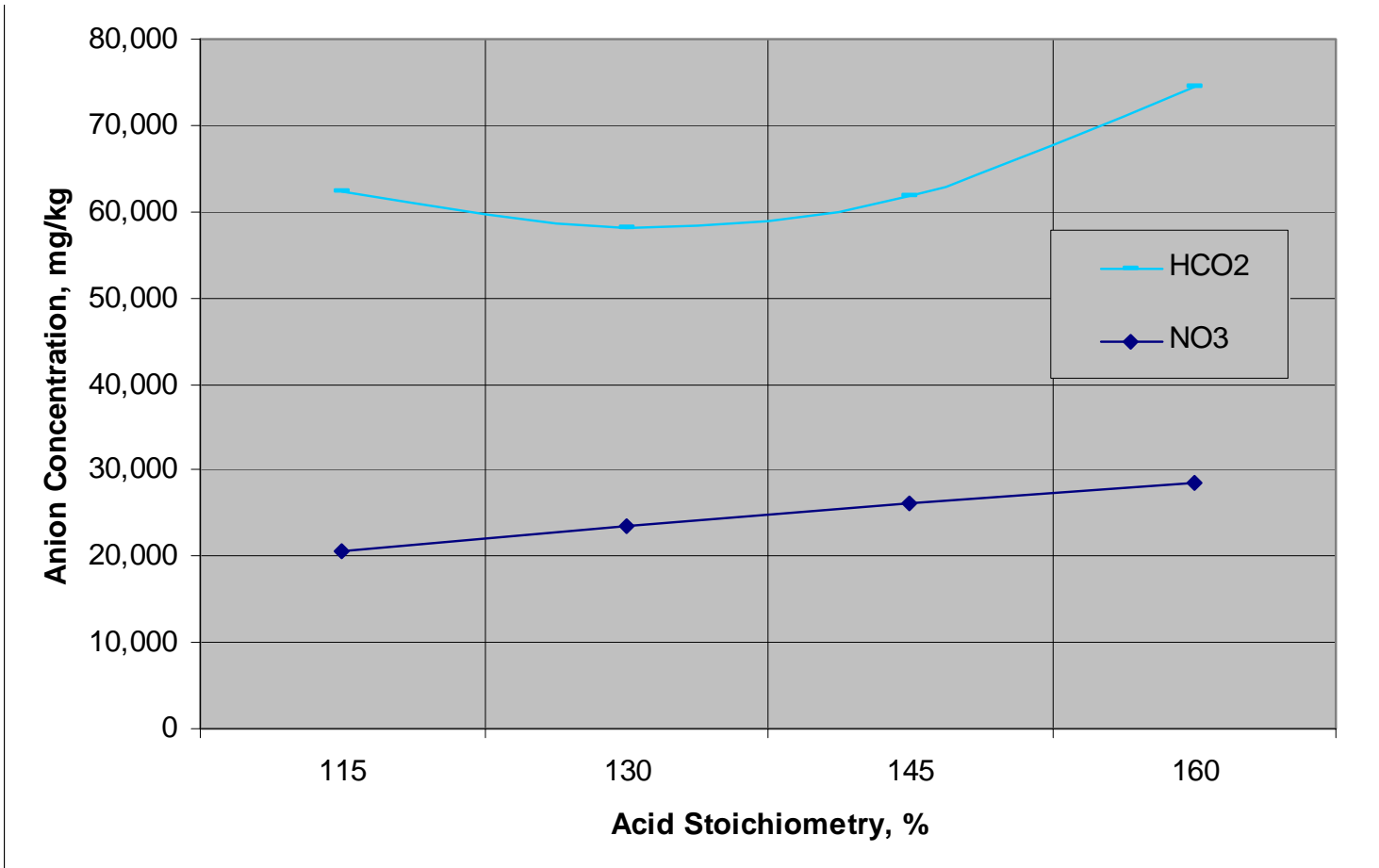

Figure B- 1d. Batch SRAT Product Nitrate and Formate versus Acid Stoichiometry 
SRNS-STI-2008-00024

Revision 0

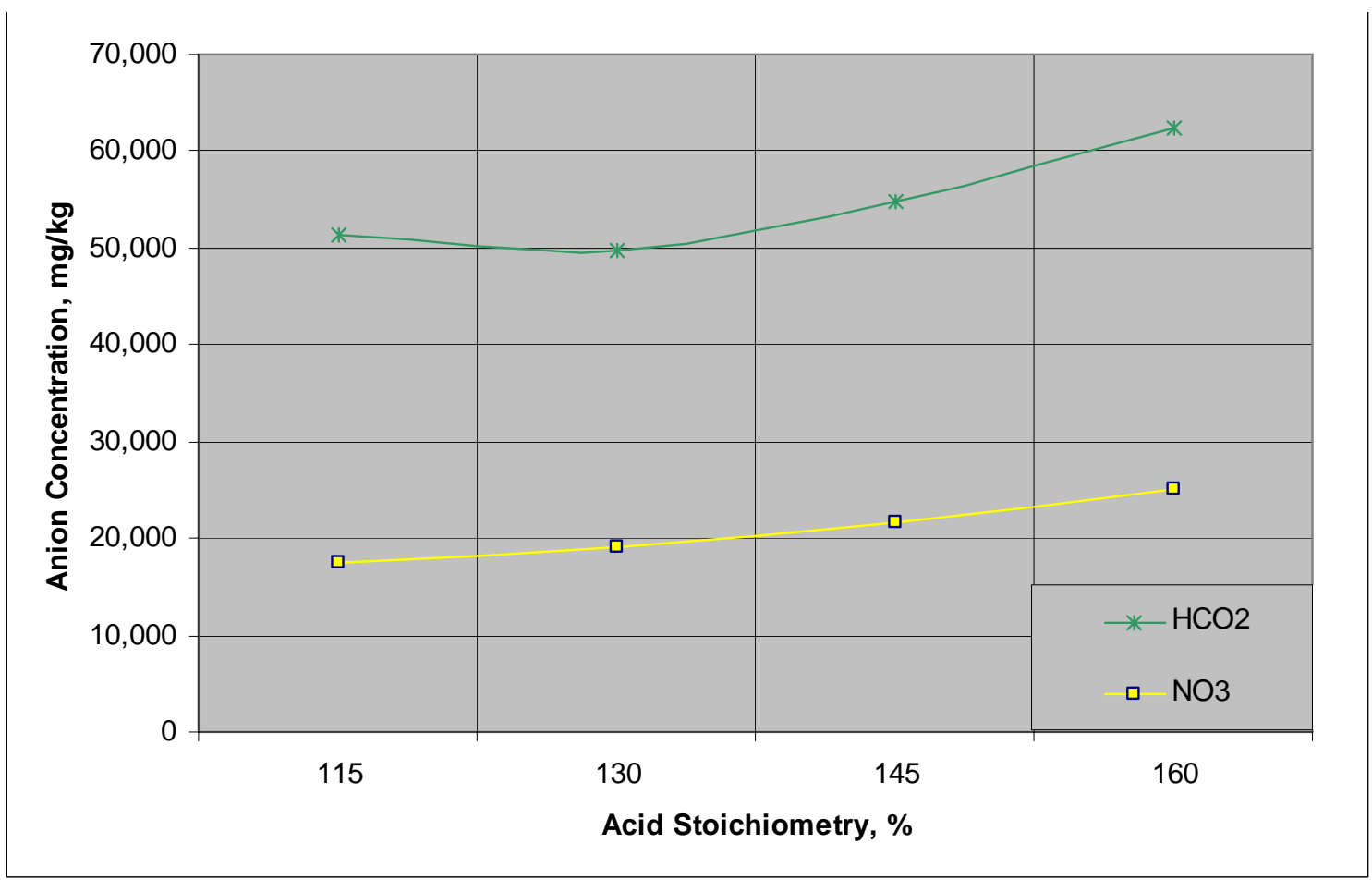

Figure B- 2c. Blend SME Product Nitrate and Formate versus Acid Stoichiometry

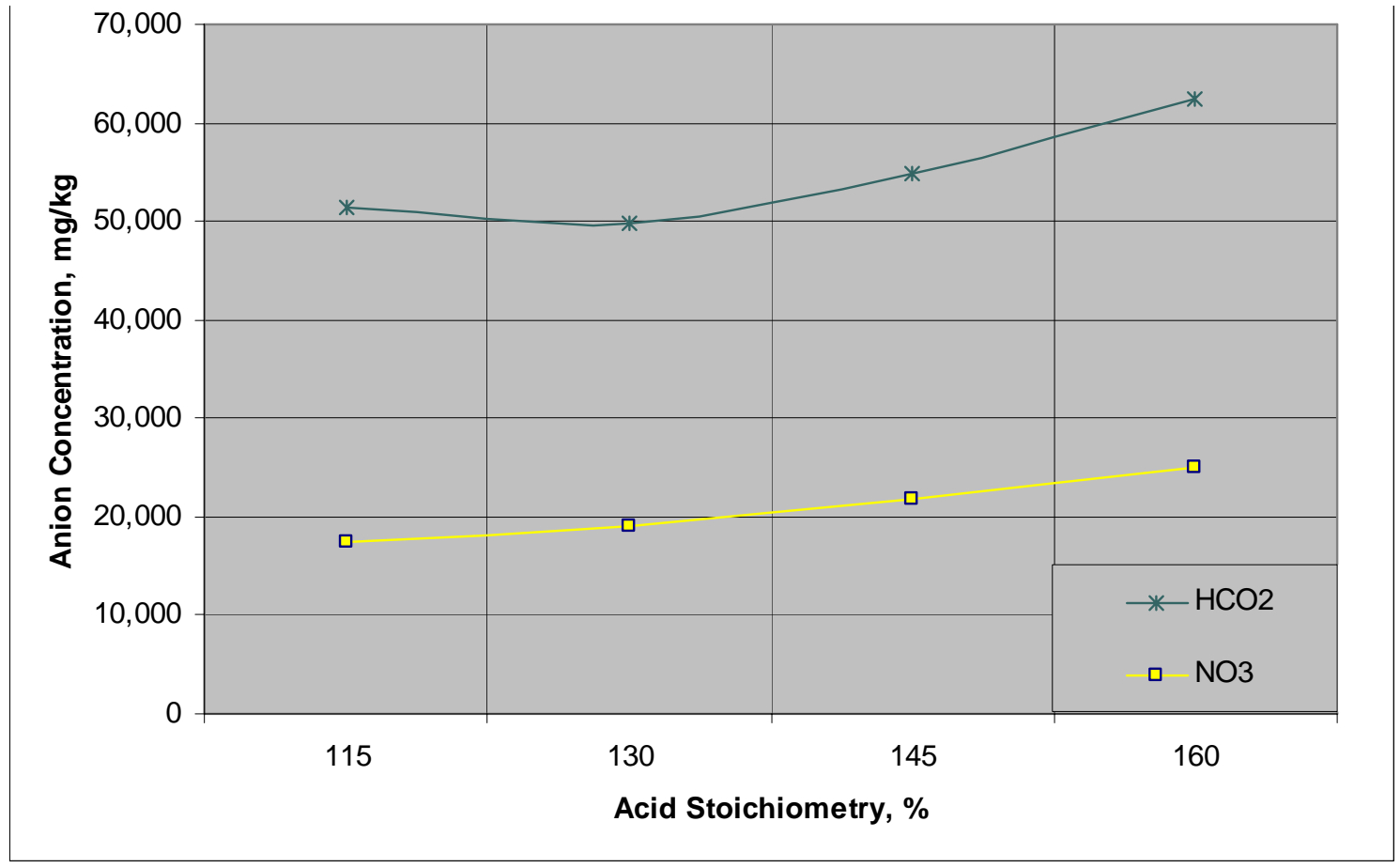

Figure B- 2d. Batch SME Product Nitrate and Formate versus Acid Stoichiometry 
SRNS-STI-2008-00024

Revision 0

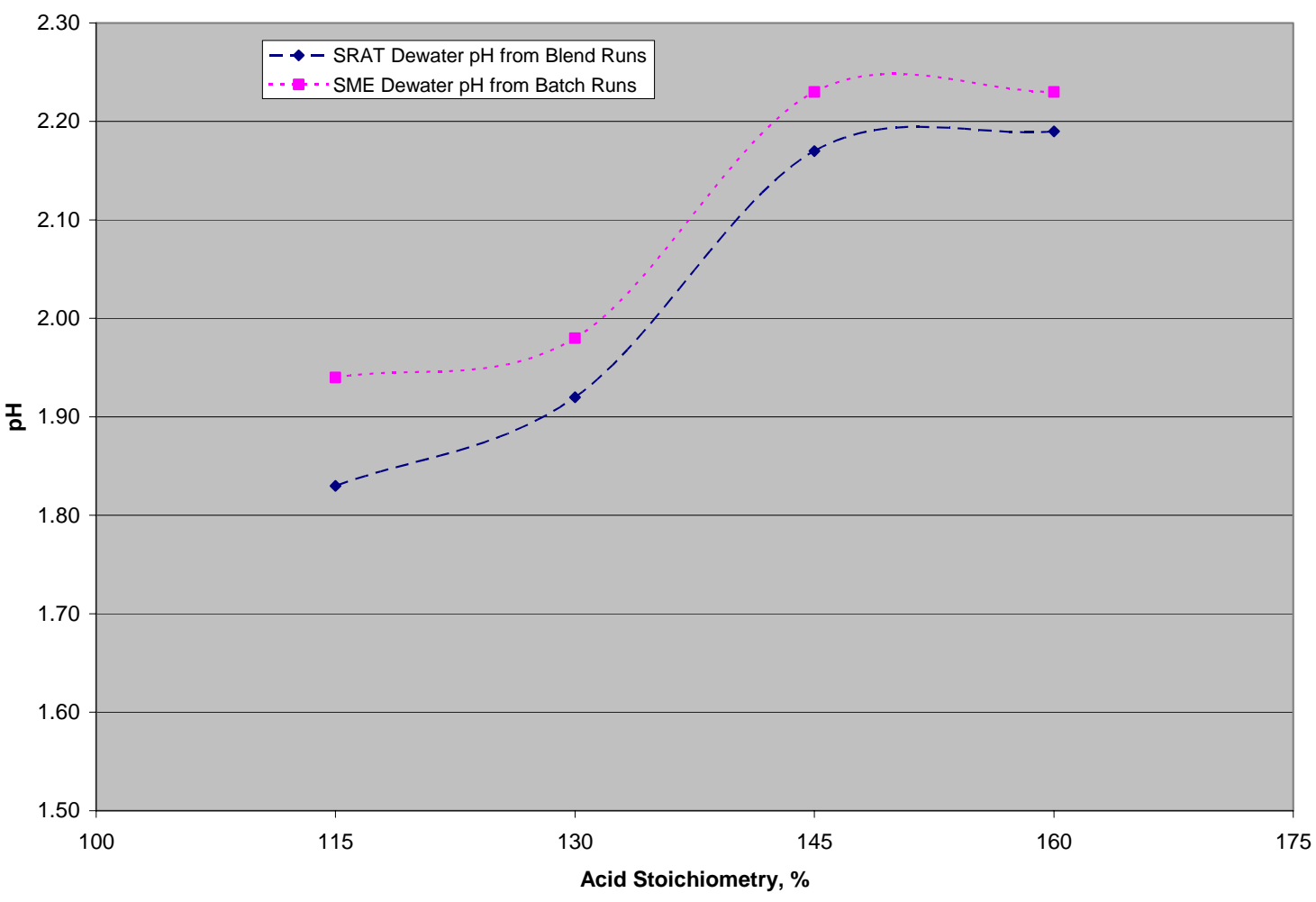

Figure B- 3c. Blend SRAT Dewater Anion Concentrations

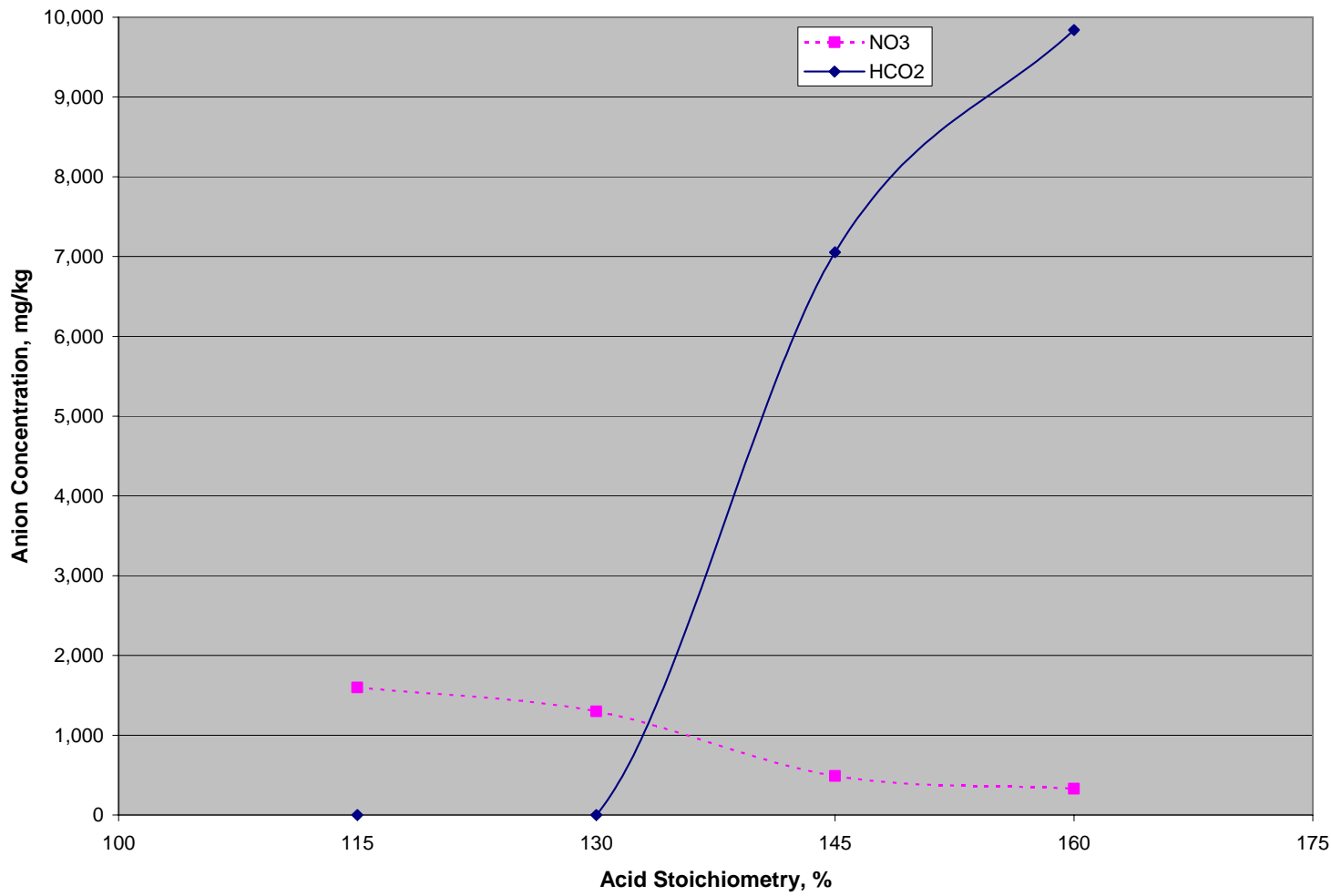

Figure B- 3d. Batch SRAT Dewater Anion Concentrations 
SRNS-STI-2008-00024

Revision 0

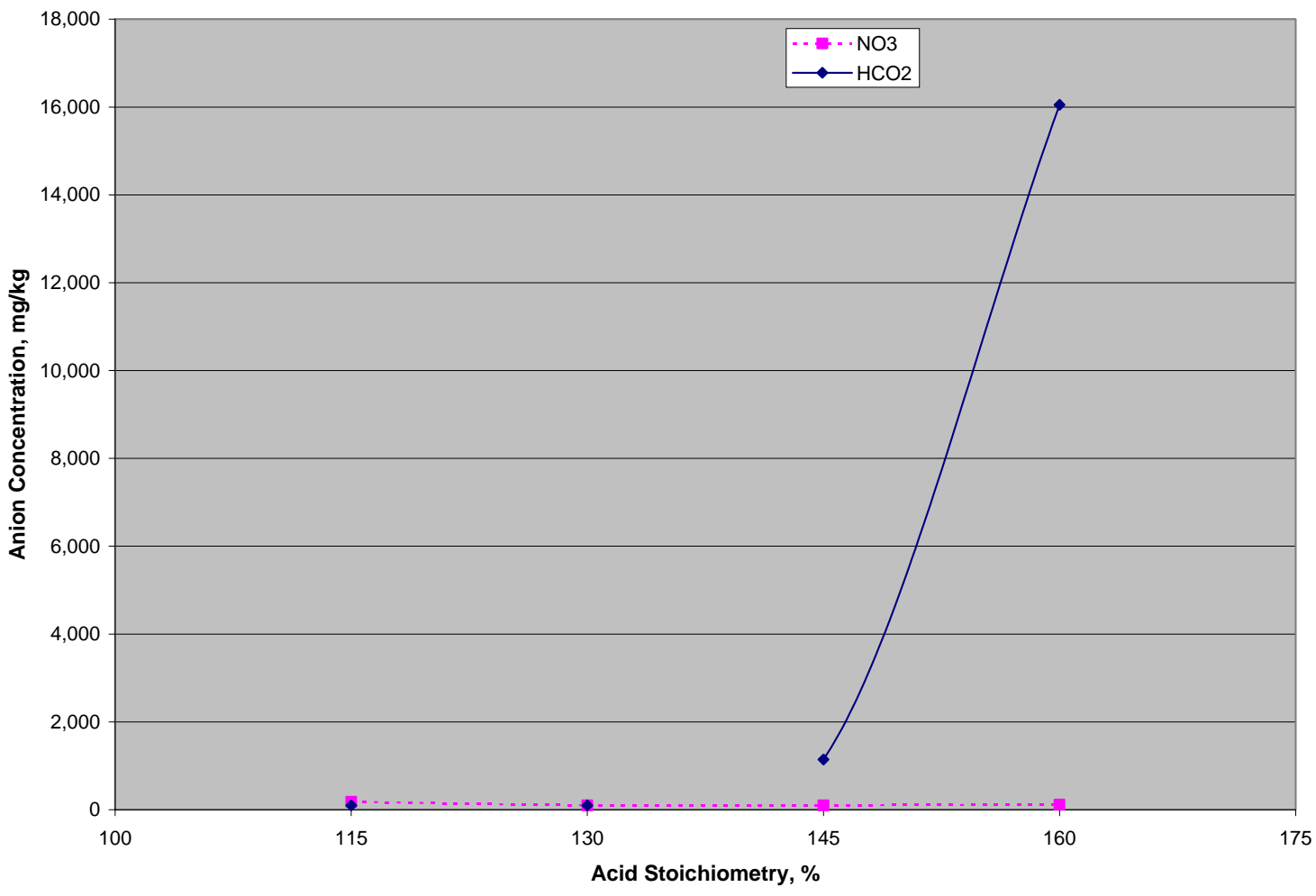

Figure B- 4c. Blend MWWT Formate Concentration

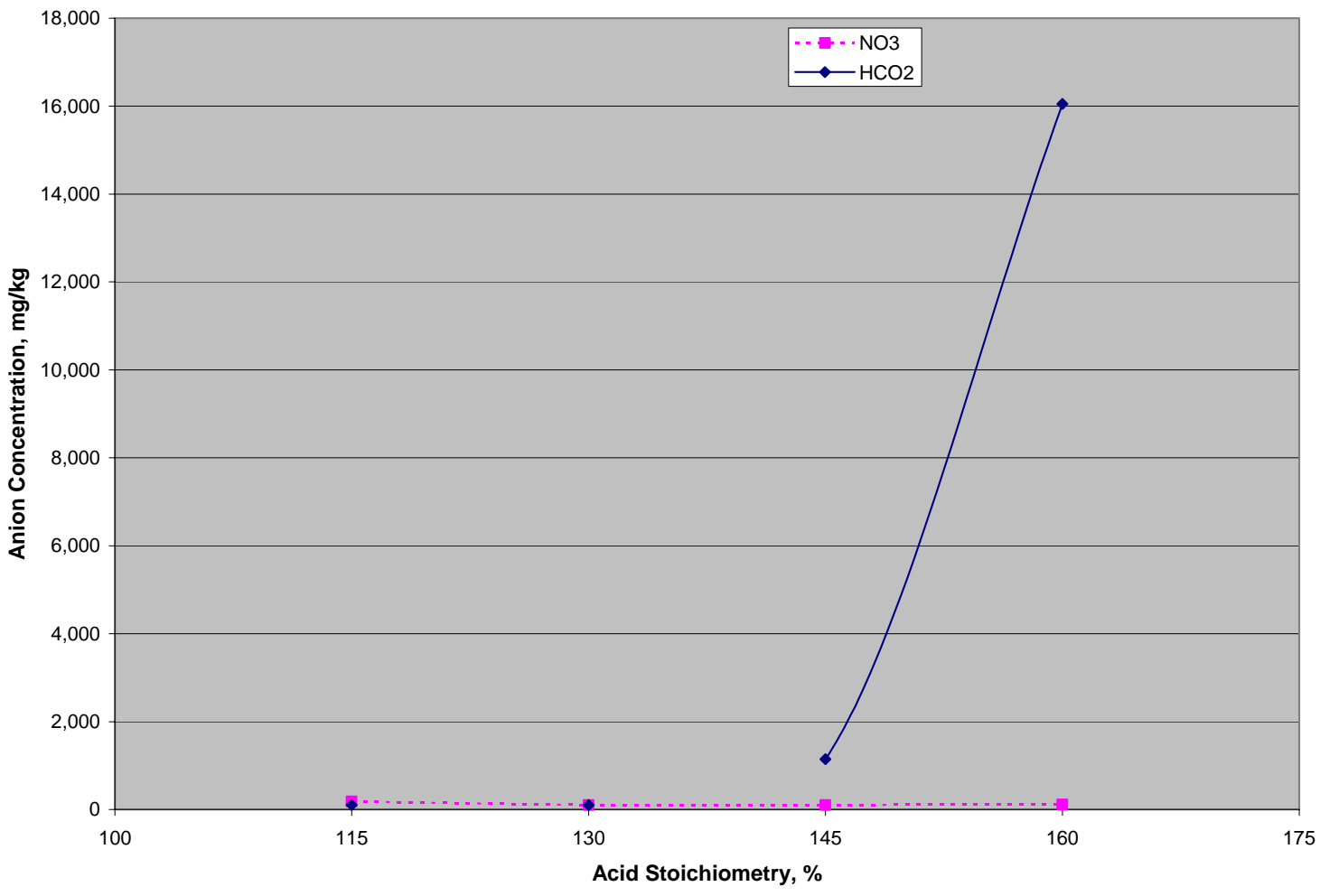

Figure B- 4d. Batch MWWT Formate Concentration 
SRNS-STI-2008-00024

Revision 0

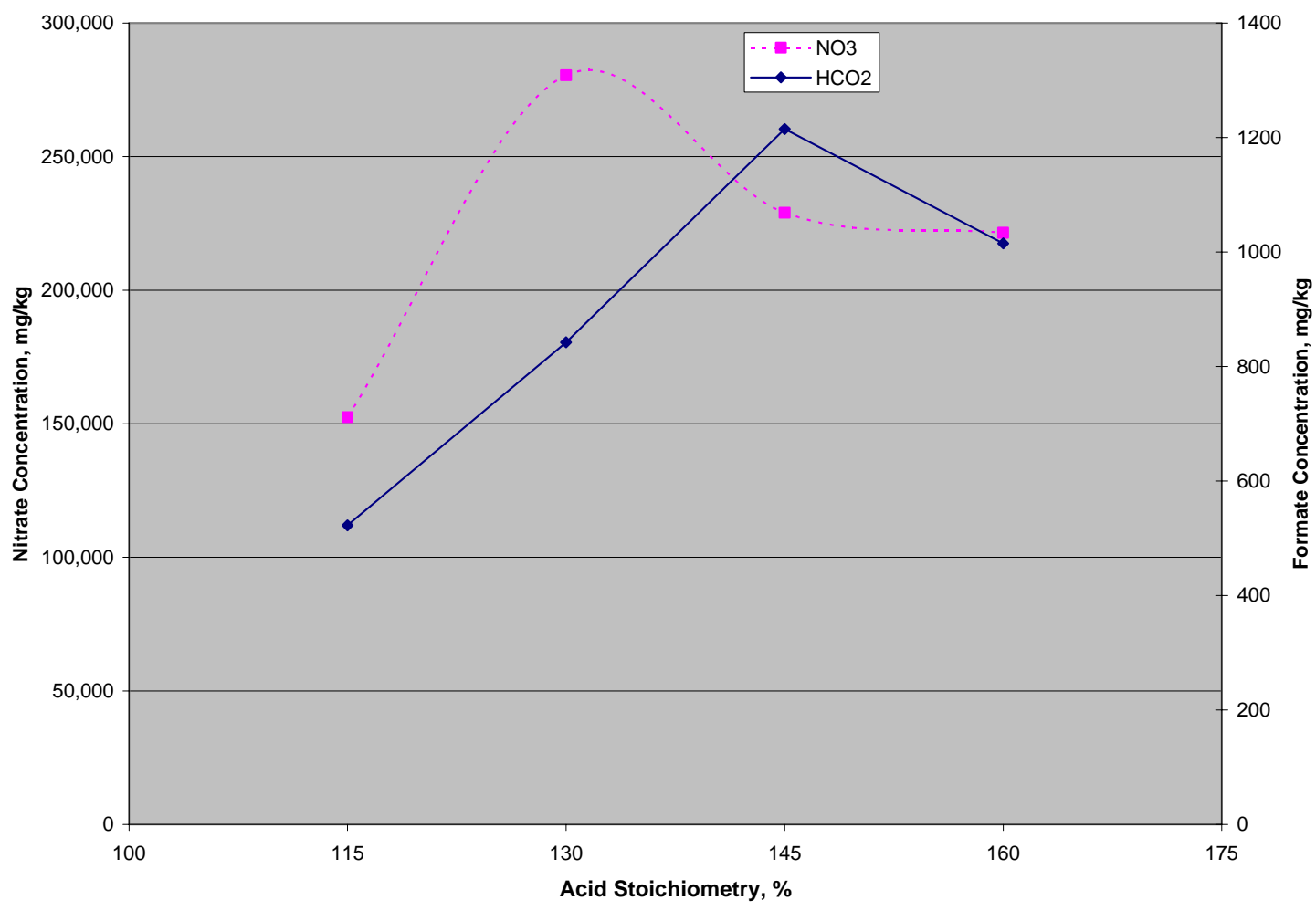

Figure B- 5c. Blend FAVC Nitrate \& Formate Concentration

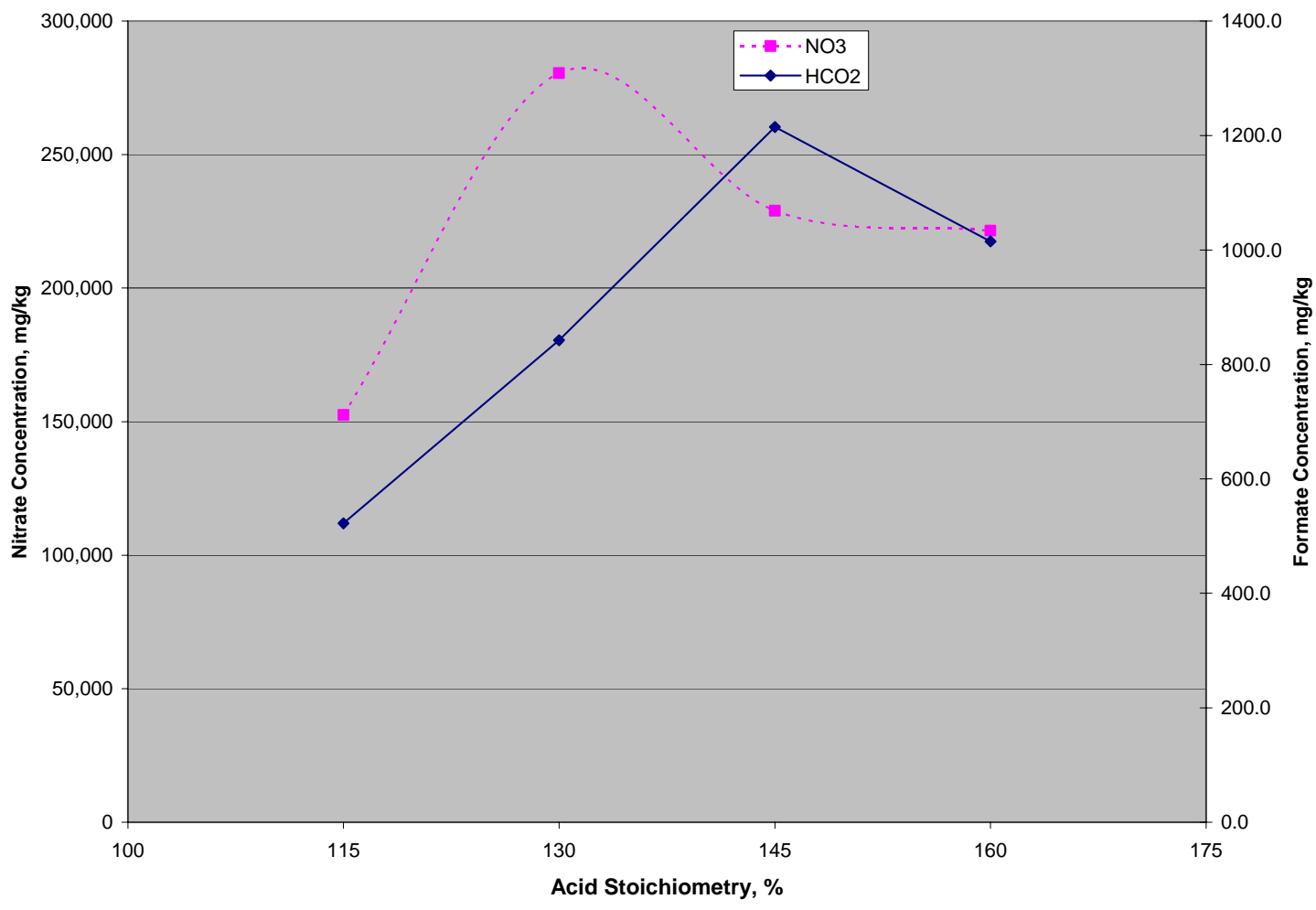

Figure B- 5d. Batch FAVC Nitrate \& Formate Concentration 


\section{Appendix C. Offgas Composition Data}

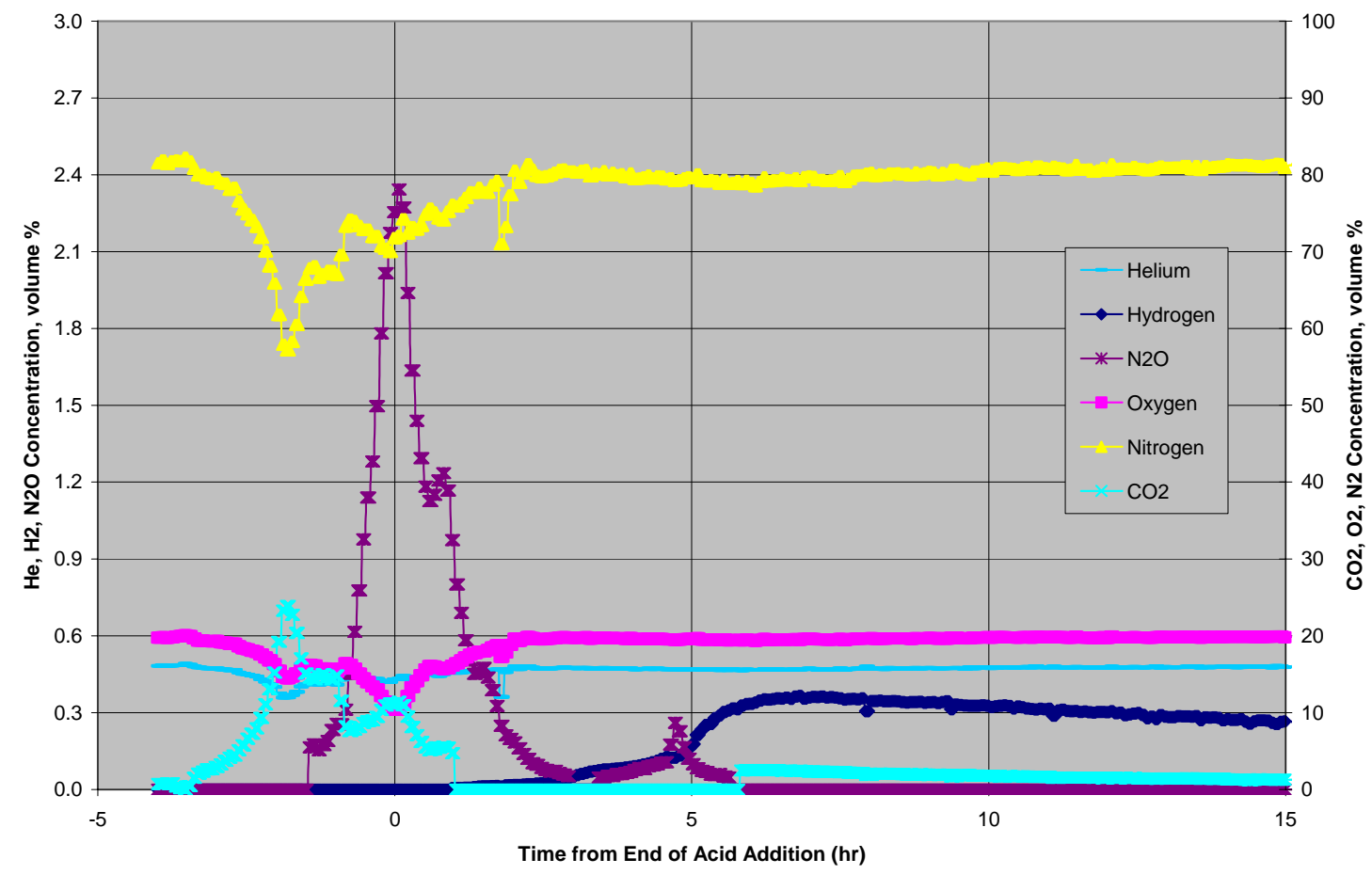

Figure C- 1. SB5-7 (115\% Acid) Offgas Data

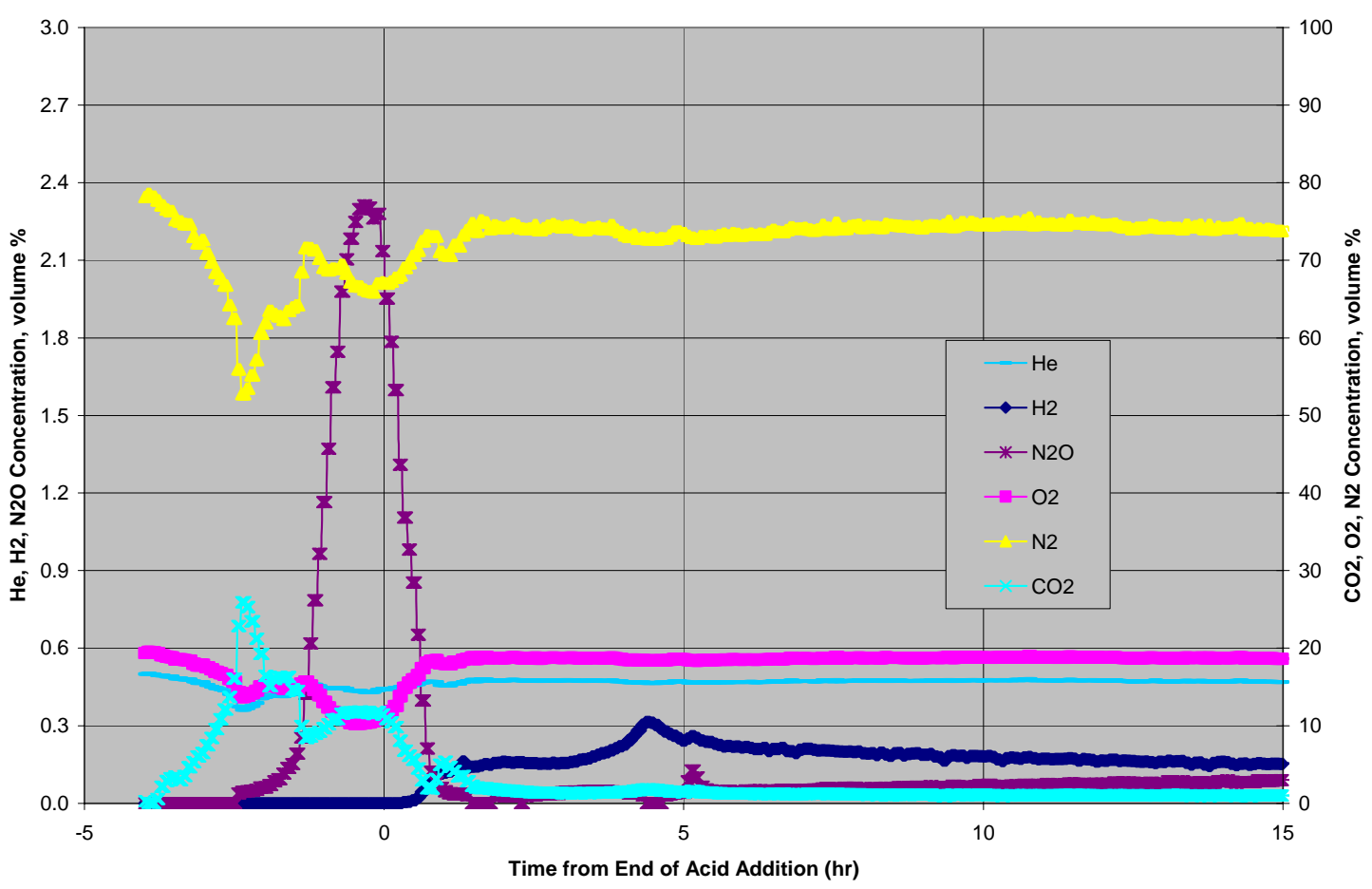

Figure C- 2. SB5-8 (130\% Acid) Offgas Data 
SRNS-STI-2008-00024

Revision 0

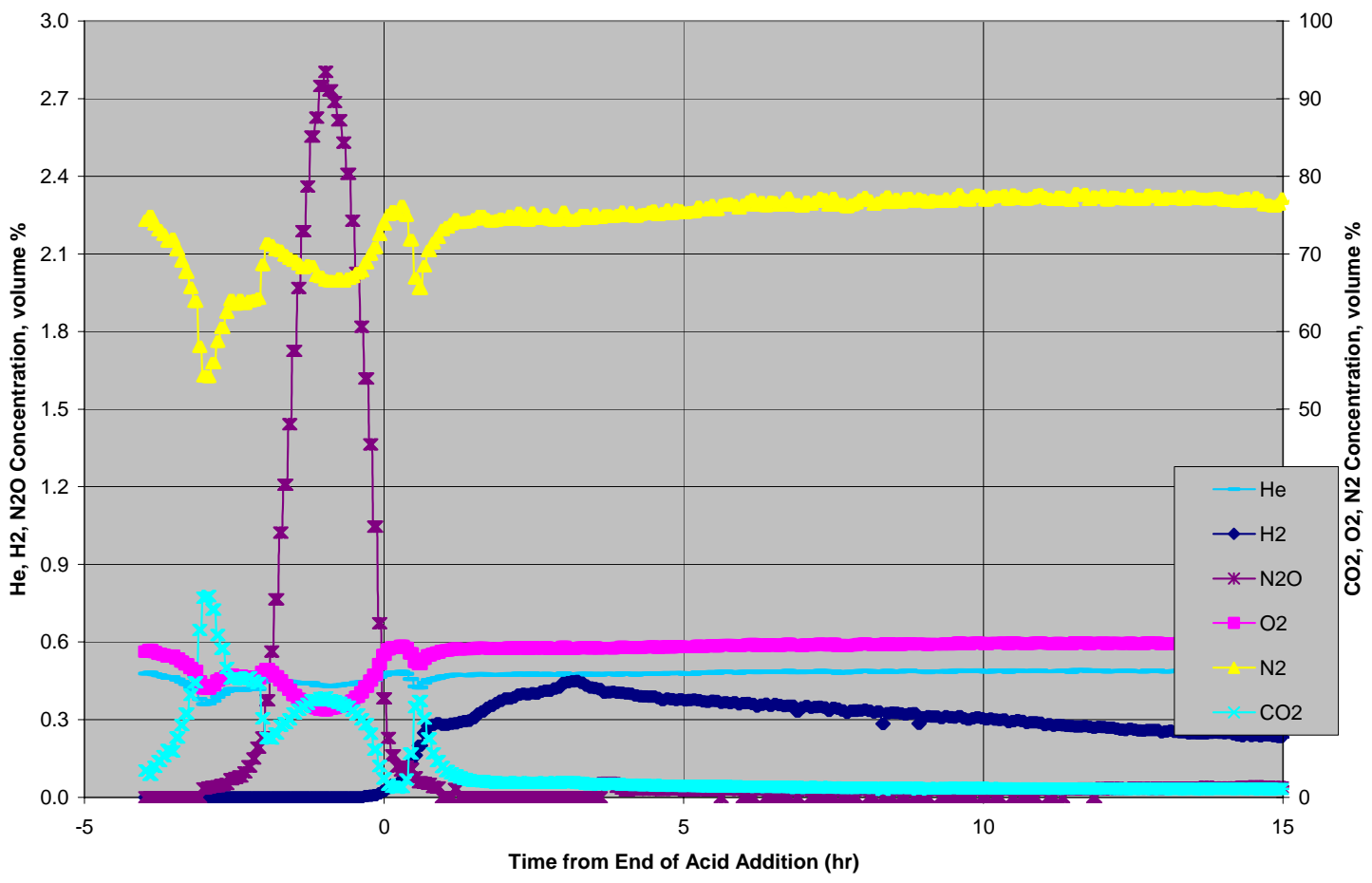

Figure C- 3. SB5-9 (145\% Acid) Offgas Data

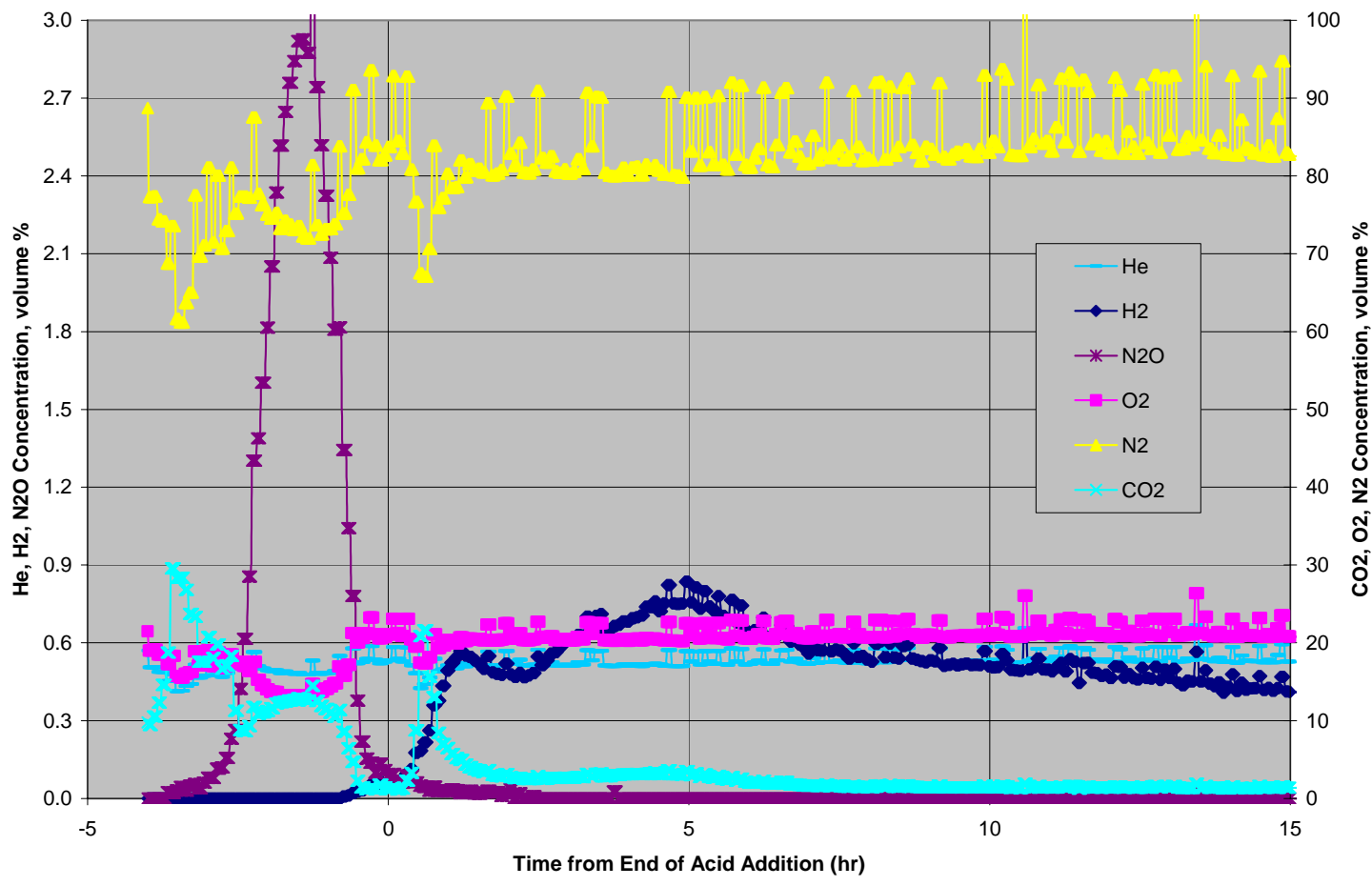

Figure C- 4. SB5-10 (160\% Acid) Offgas Data 
SRNS-STI-2008-00024

Revision 0

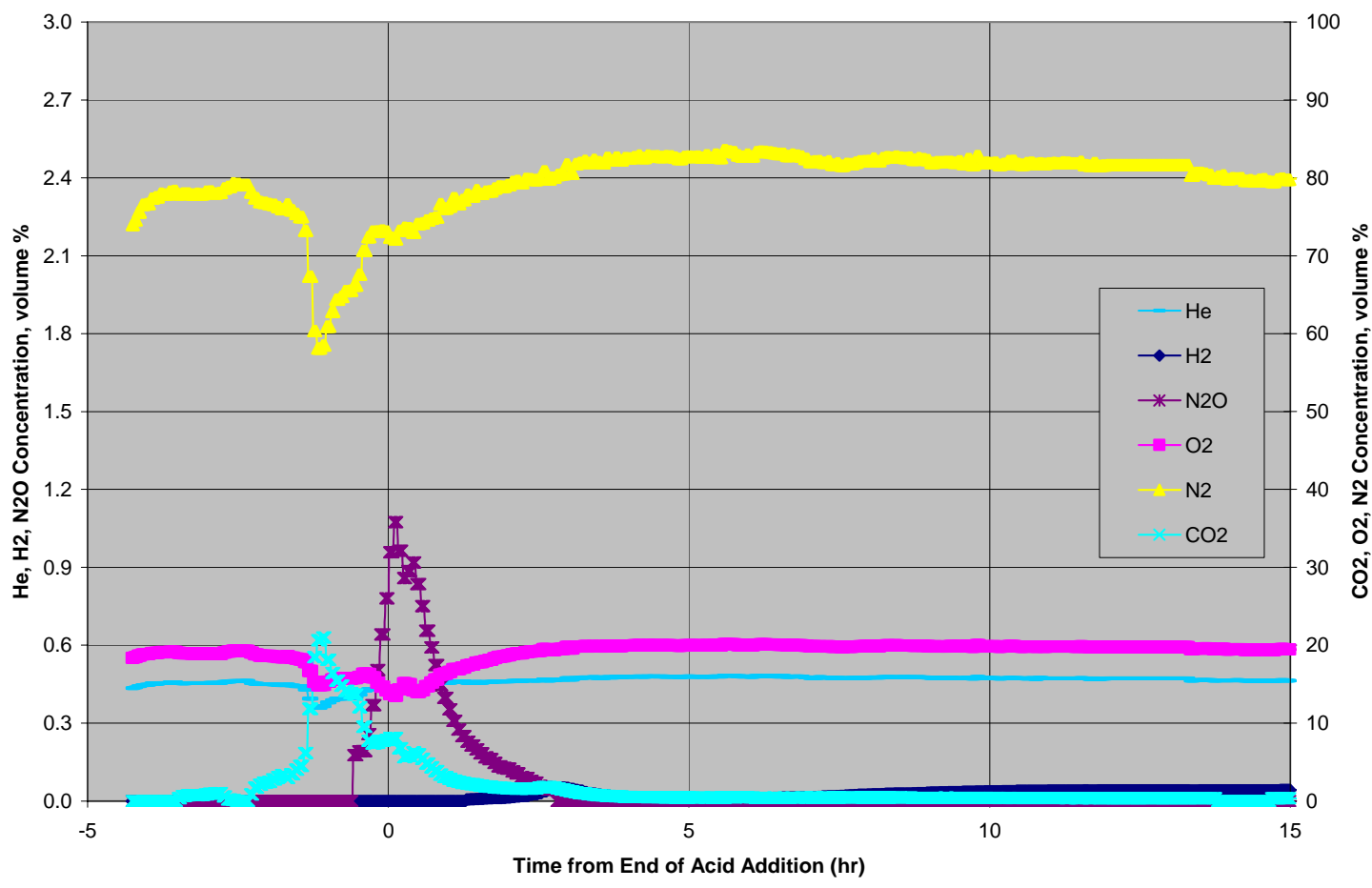

Figure C- 5. SB5-11 (115\% Acid) Offgas Data

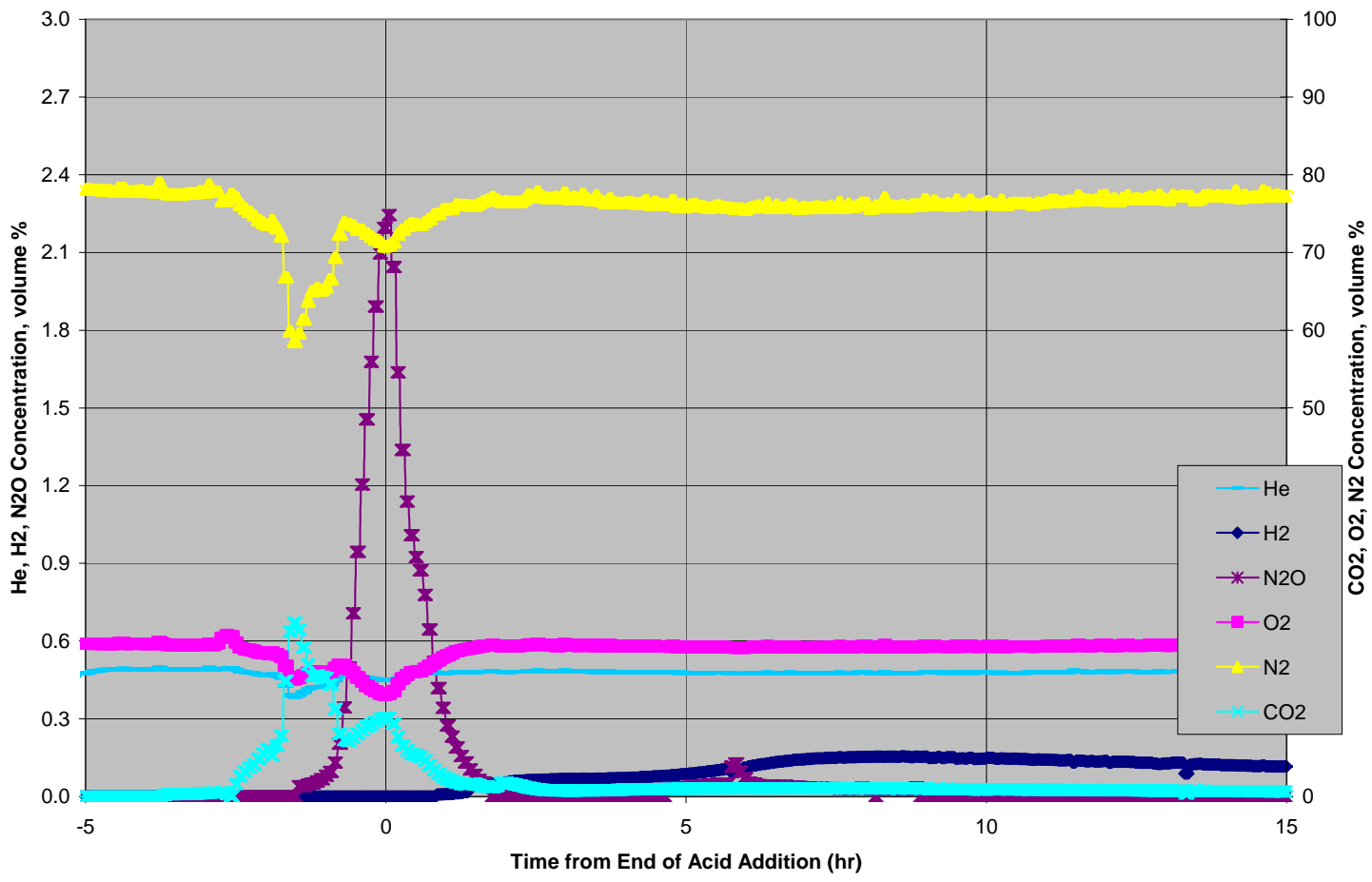

Figure C- 6. SB5-12 (130\% Acid) Offgas Data 


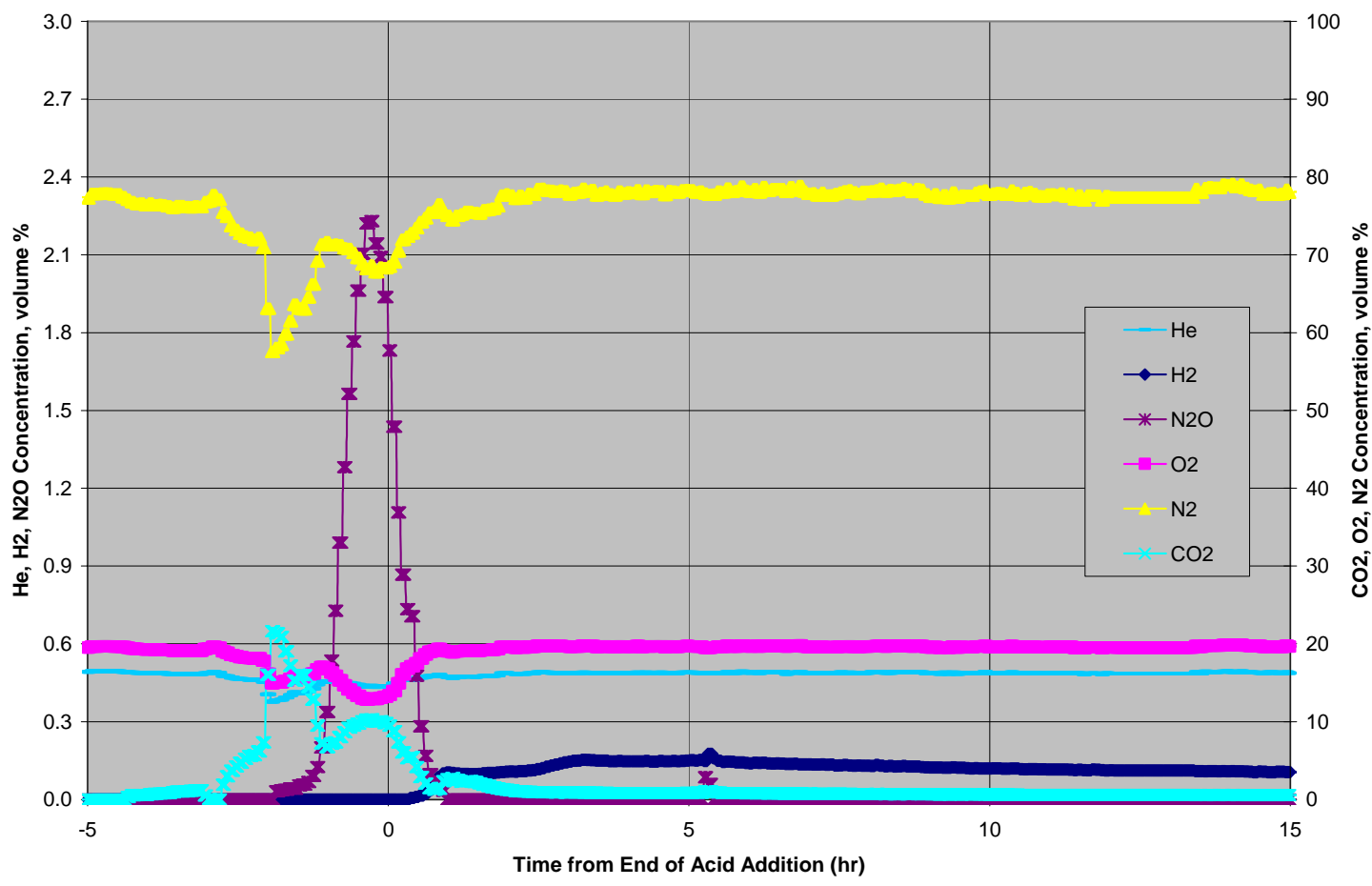

Figure C- 7. SB5-13 (145\% Acid) Offgas Data

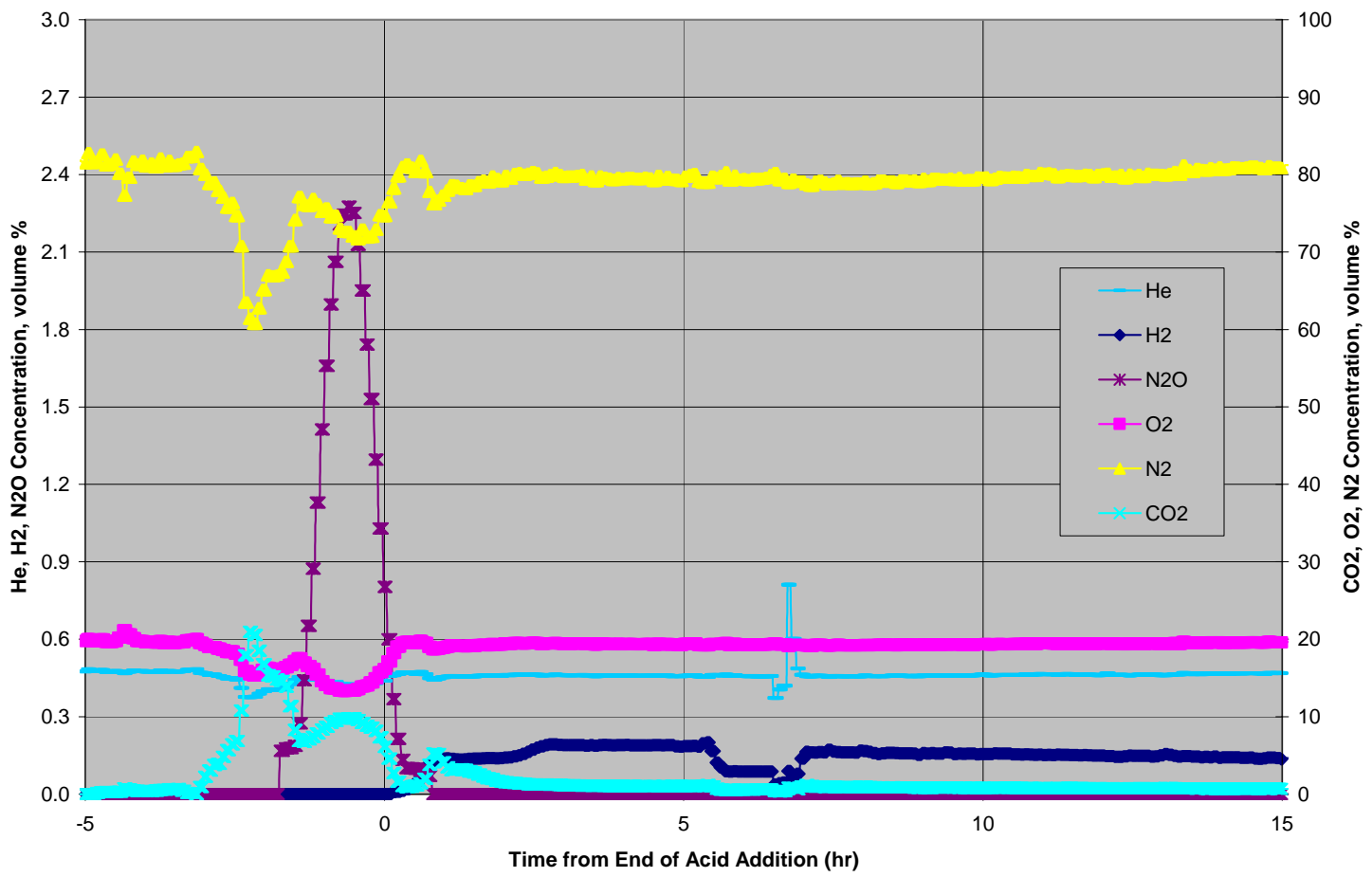

Figure C- 8. SB5-14 (160\% Acid) Offgas Data 
SRNS-STI-2008-00024

Revision 0

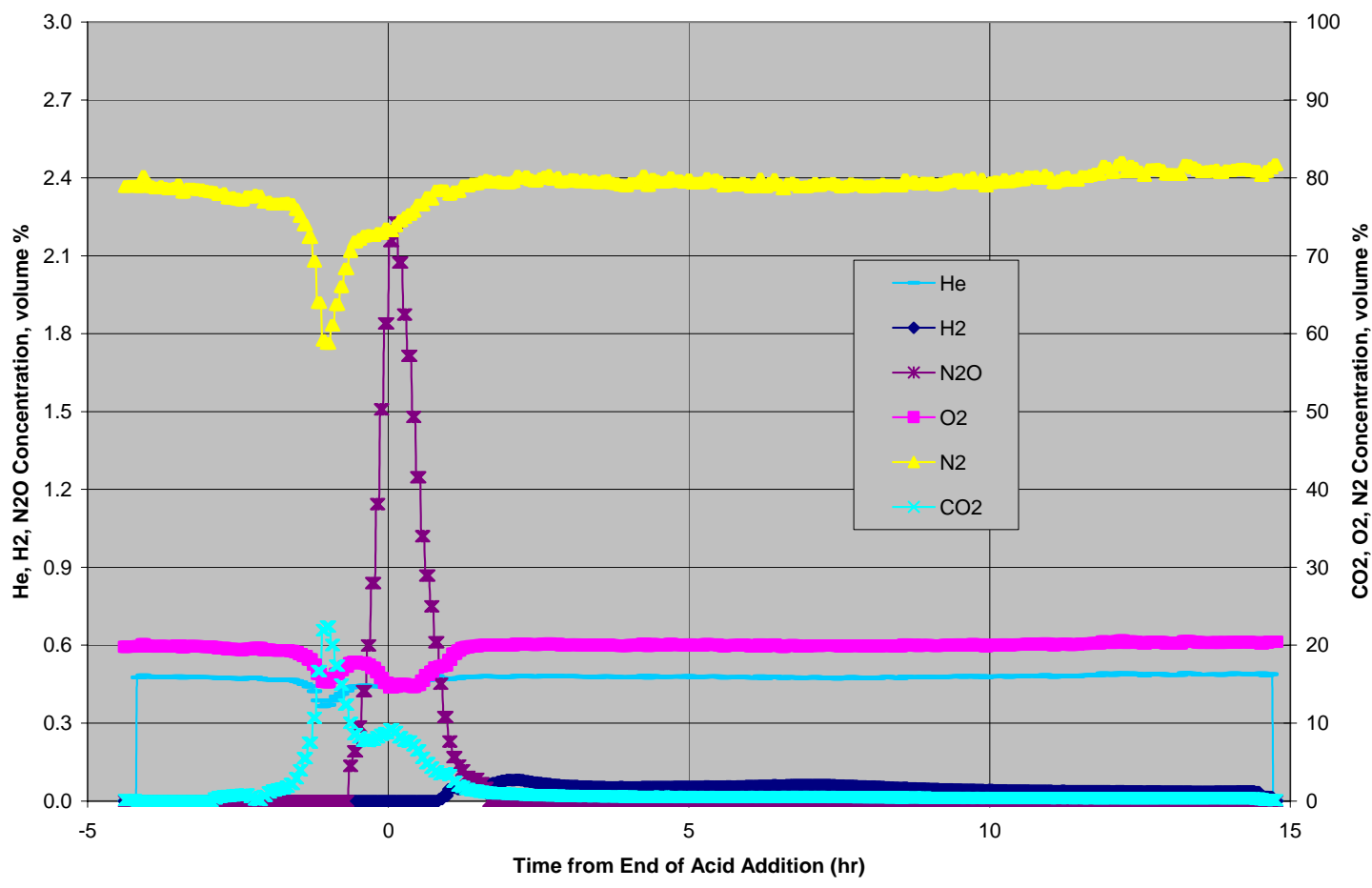

Figure C- 9. SB5-15 (130\% Acid) Offgas Data

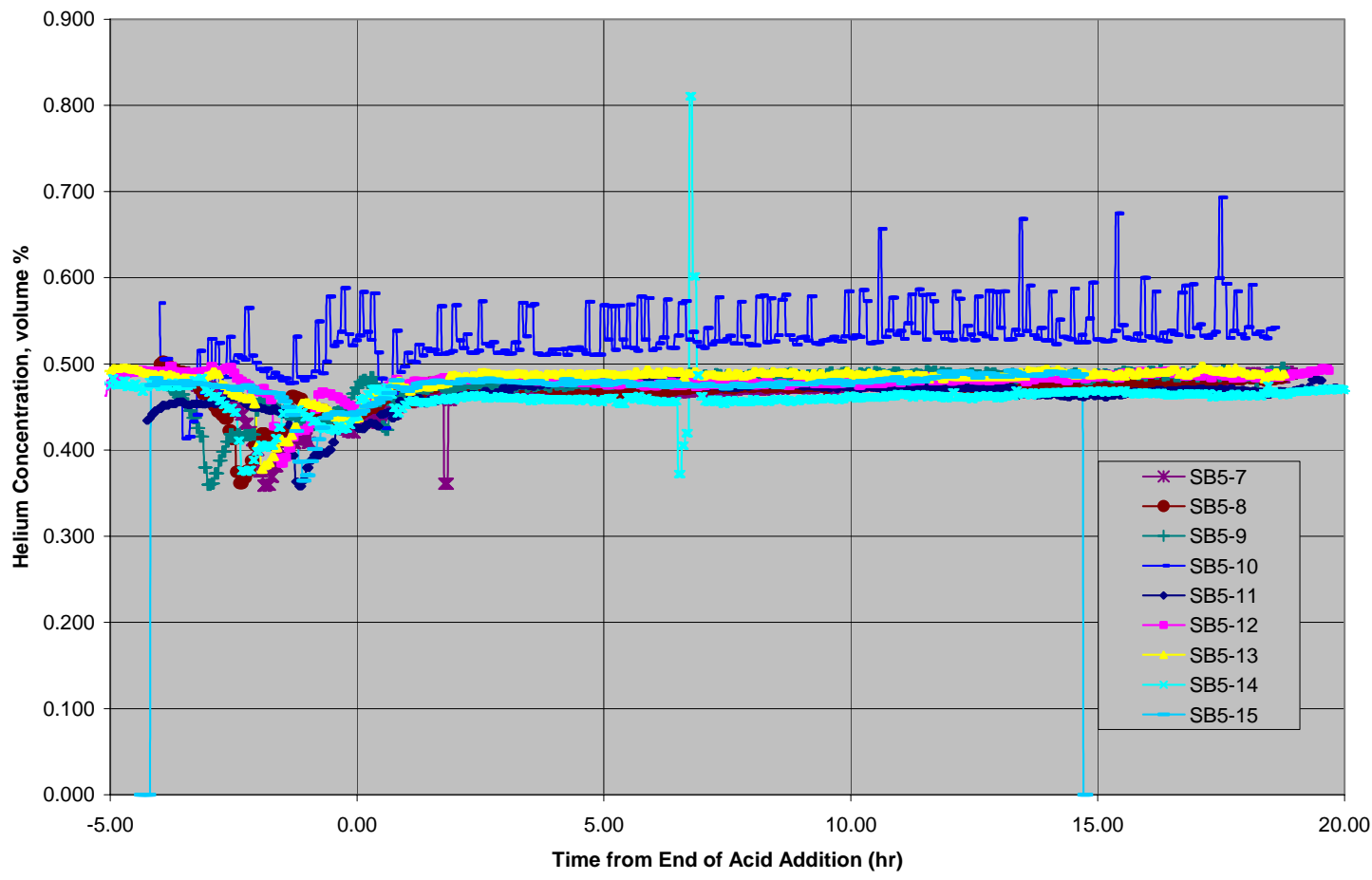

Figure C- 10. Helium Profiles 


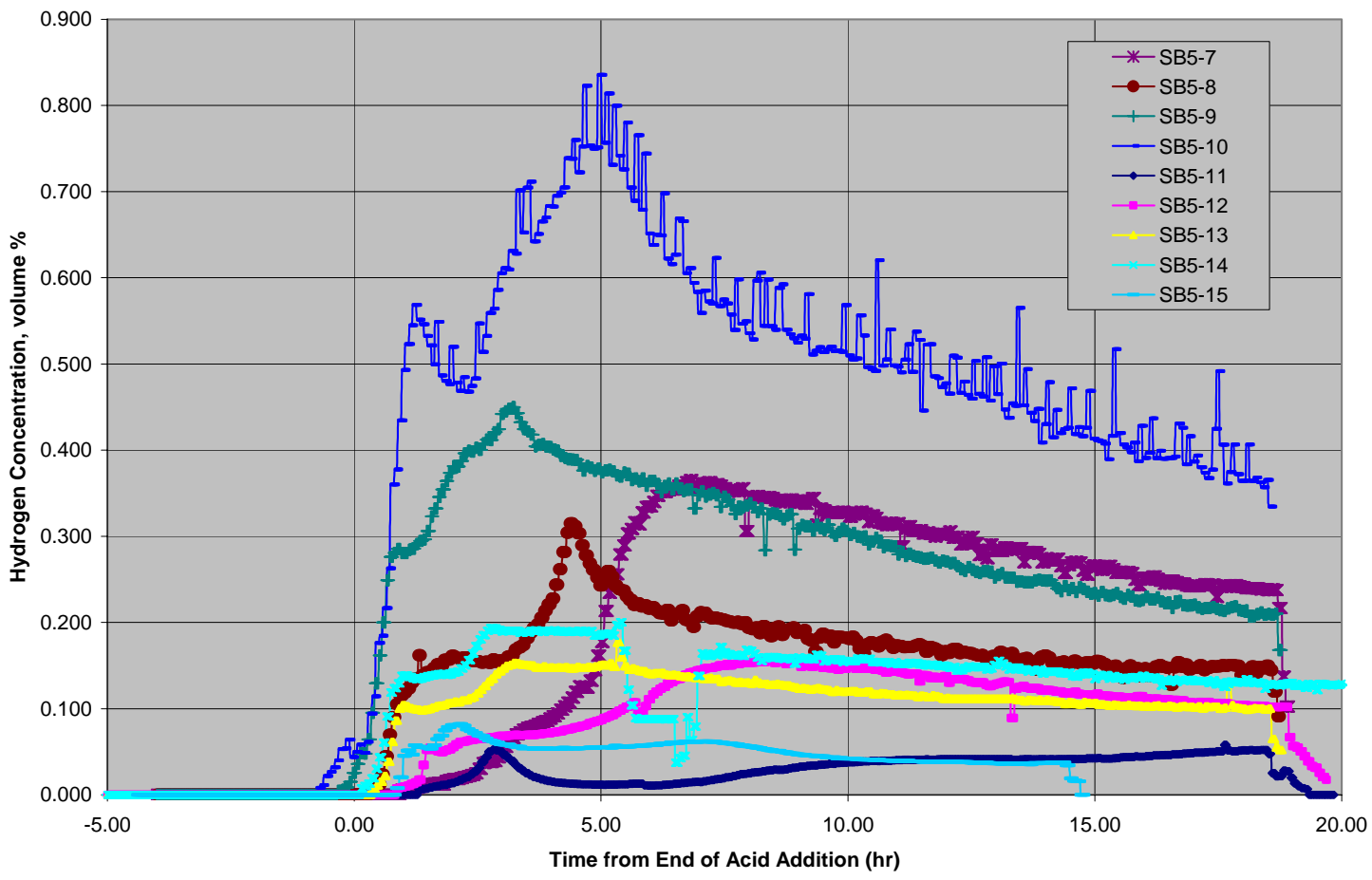

Figure C- 11. Oxygen Profiles

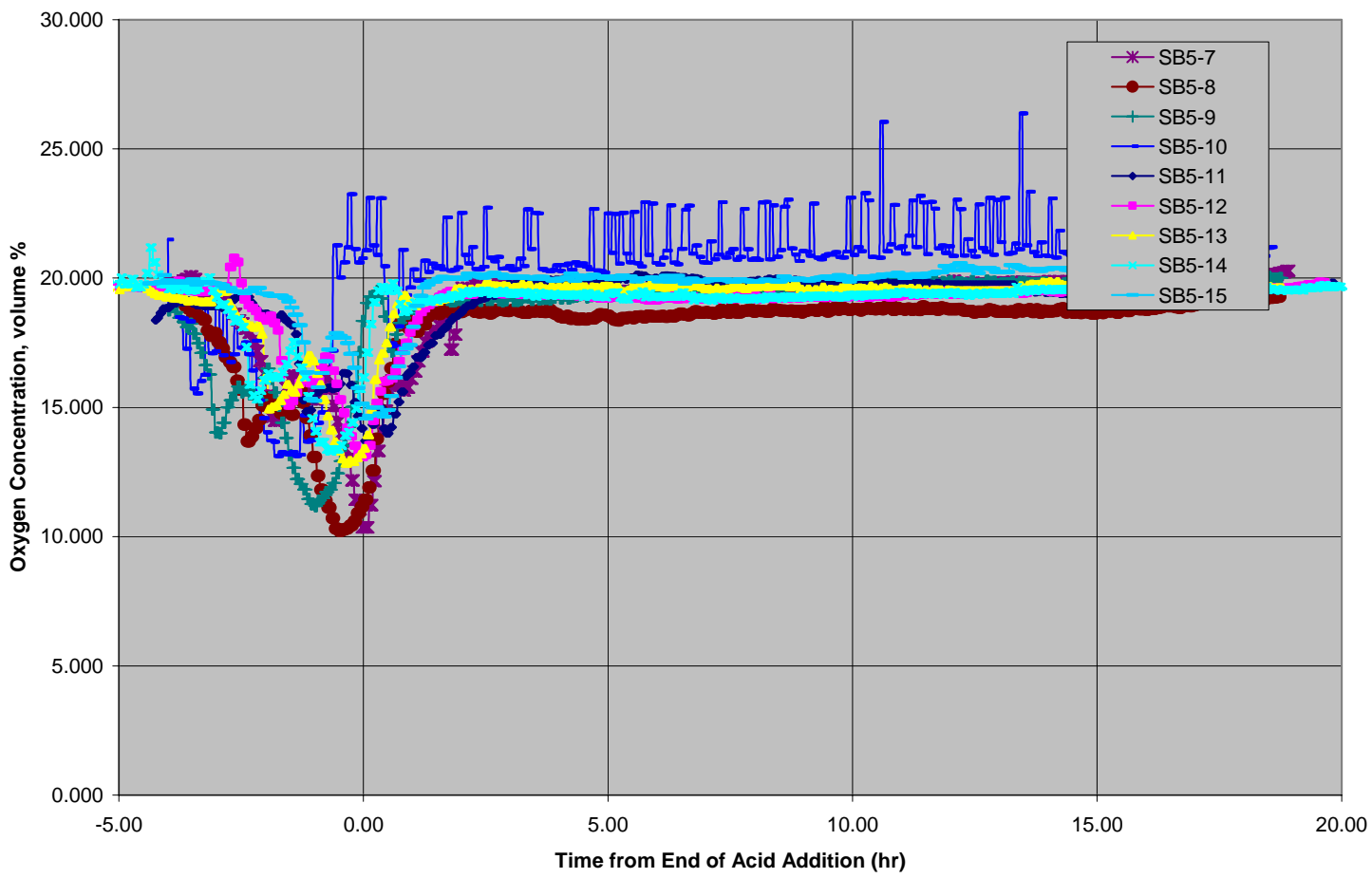

Figure C- 12. Oxygen Profiles 


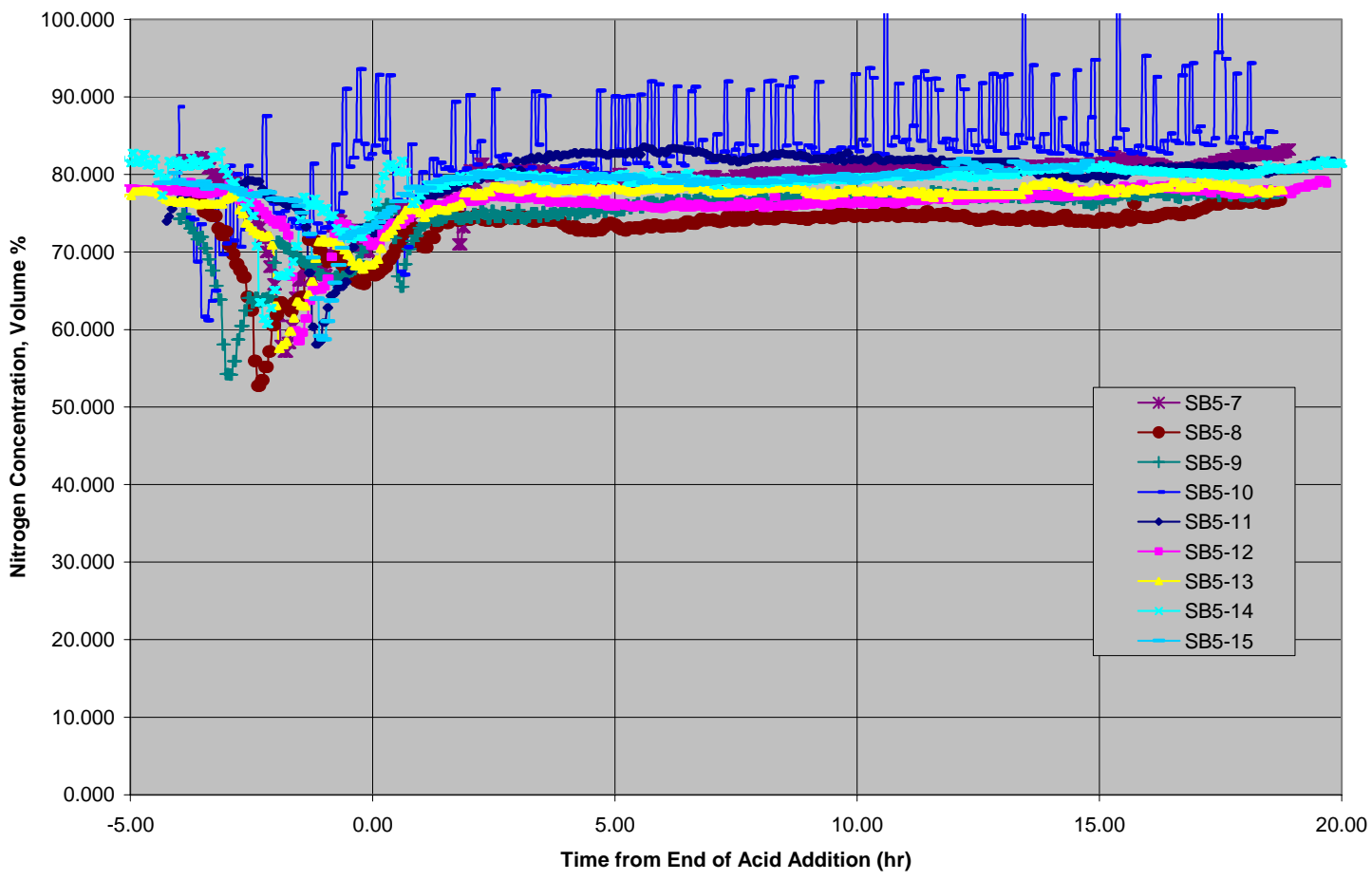

Figure C- 13. Nitrogen Profiles

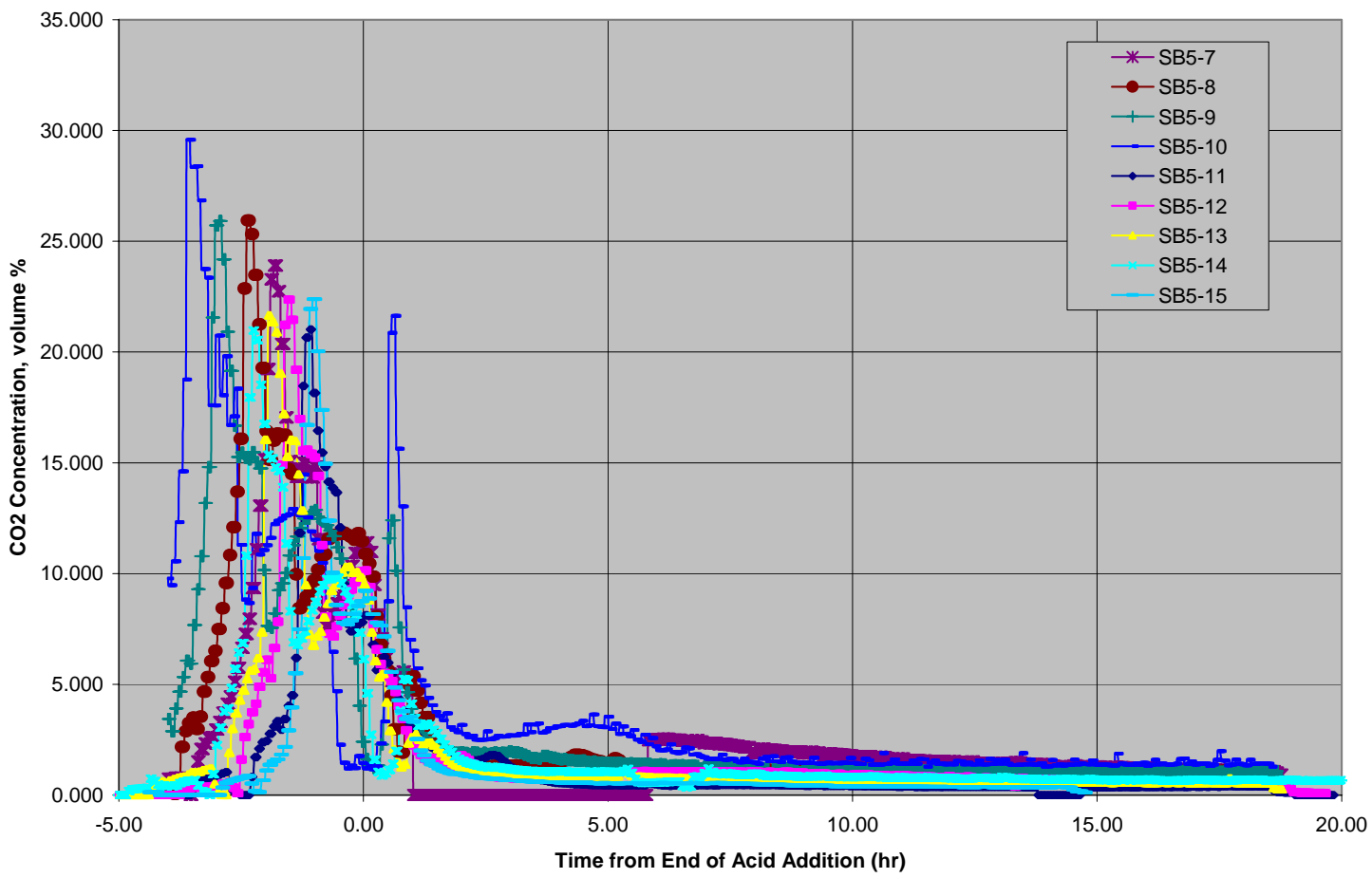

Figure C- 14. Carbon Dioxide Profiles 
SRNS-STI-2008-00024

Revision 0

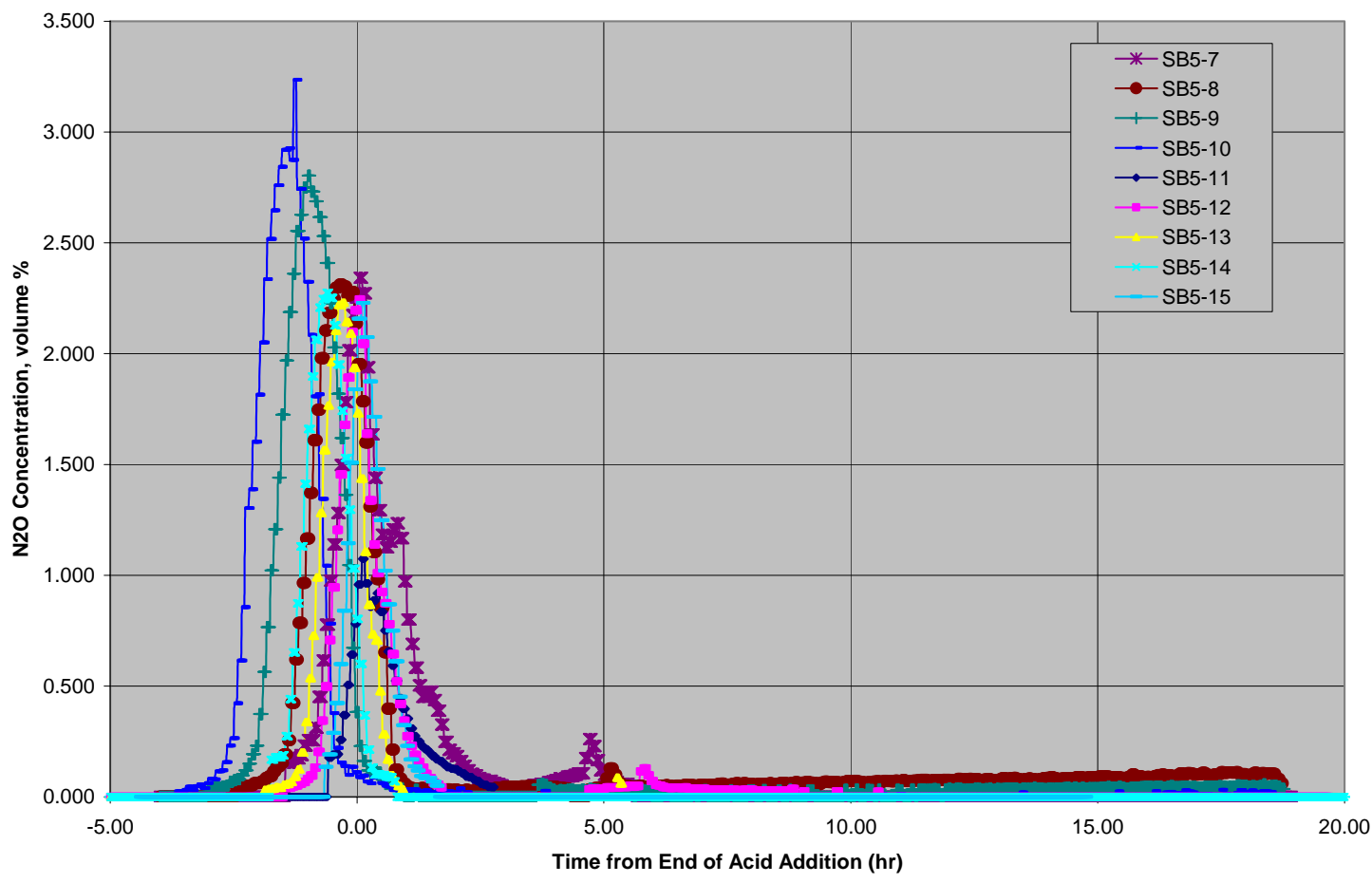

Figure C- 15. Nitrous Oxide Profiles 


\section{Appendix D. Rheological Results Charts and Flow Curves}

Figure D- 1. SB5-7 (115\% Acid) SRAT Product Flow Curves

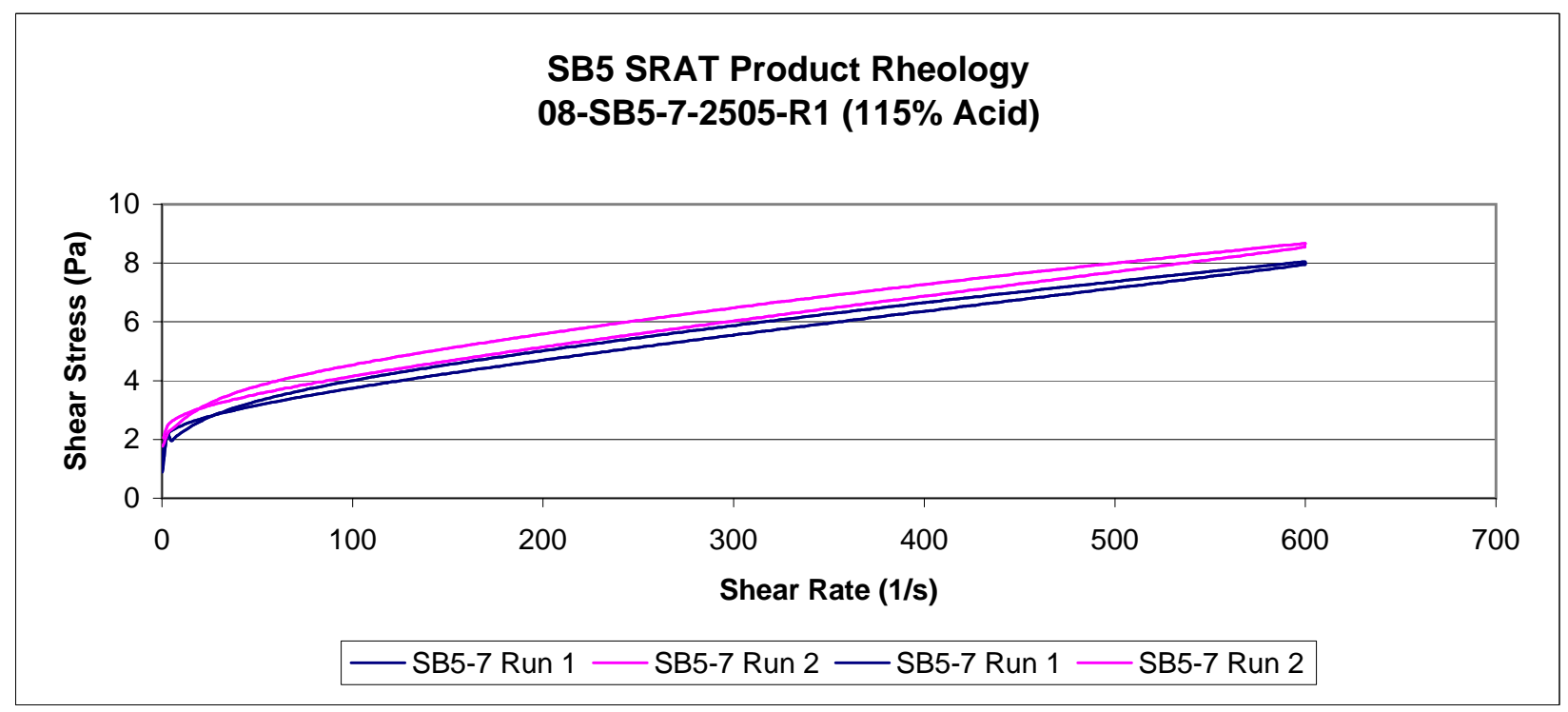

\begin{tabular}{|r|c|c|c|c|}
\hline & \multicolumn{2}{|c|}{ Run 1 } & \multicolumn{2}{c|}{ Run 1 } \\
\hline Curve & Yield Stress, Pa & Consistency, cP & Yield Stress, $\mathrm{Pa}$ & Consistency, CP \\
\hline up & 3.32 & 8.17 & 3.85 & 8.36 \\
\hline down & 2.99 & 8.35 & 3.36 & 8.73 \\
\hline
\end{tabular}

Figure D- 2. SB5-8 (130\% Acid) SRAT Product Flow Curves

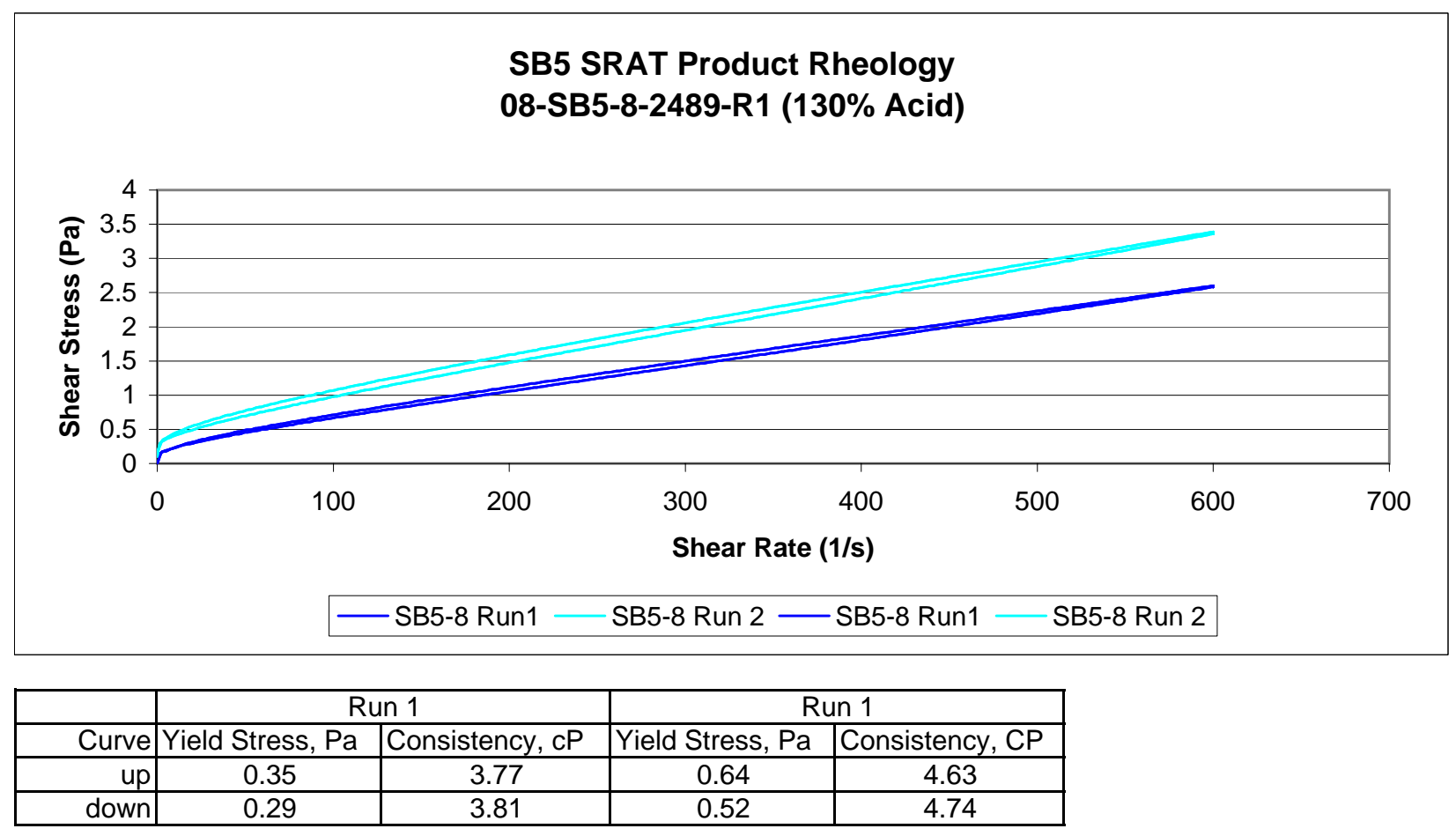


Figure D- 3. SB5-9 (145\% Acid) SRAT Product Flow Curves

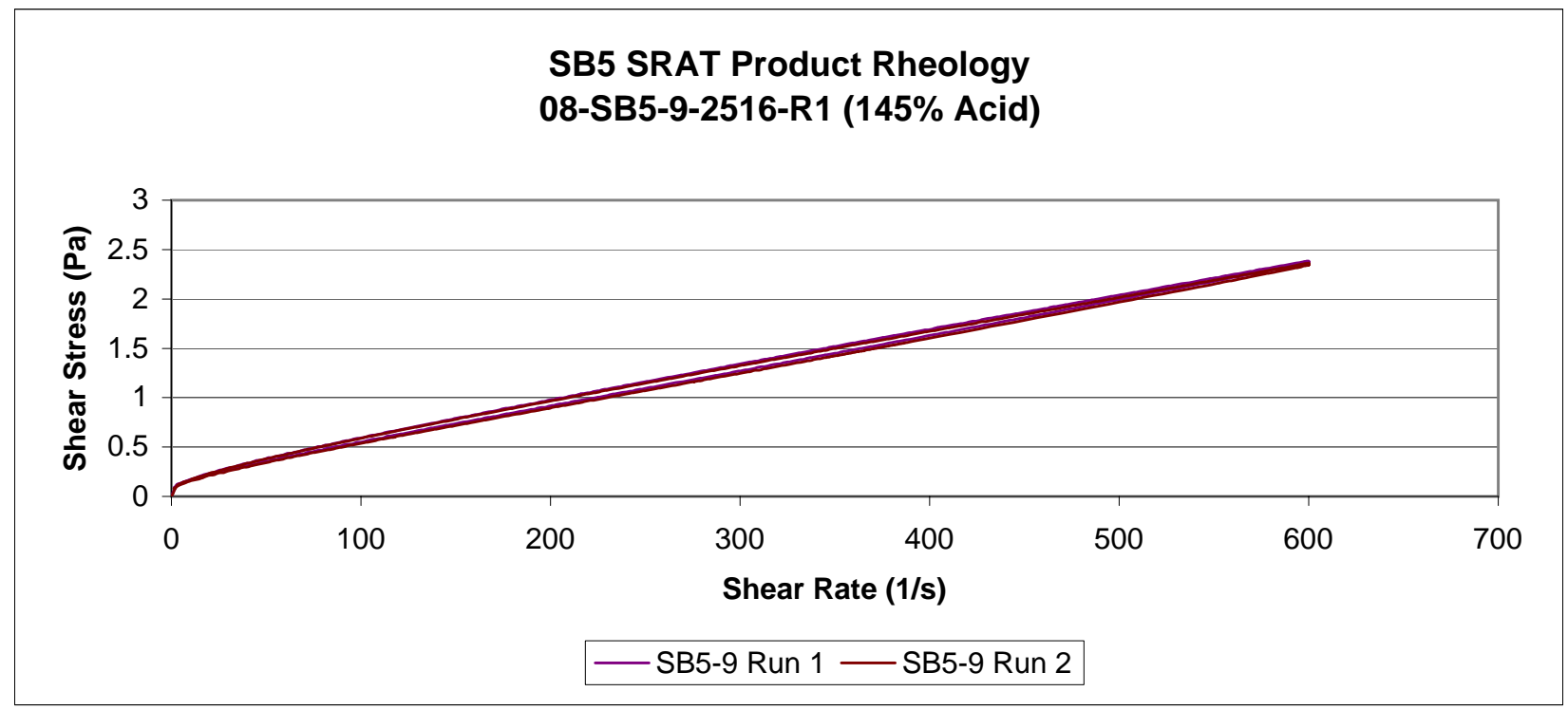

\begin{tabular}{|r|c|c|c|c|}
\hline & \multicolumn{2}{|c|}{ Run 1 } & \multicolumn{2}{c|}{ Run 1 } \\
\hline Curve & Yield Stress, Pa & Consistency, cP & Yield Stress, $\mathrm{Pa}$ & Consistency, CP \\
\hline up & 0.25 & 3.58 & 0.25 & 3.54 \\
\hline down & 0.19 & 3.61 & 0.17 & 3.58 \\
\hline
\end{tabular}

Figure D- 4. SB5-10 (160\% Acid) SRAT Product Flow Curves

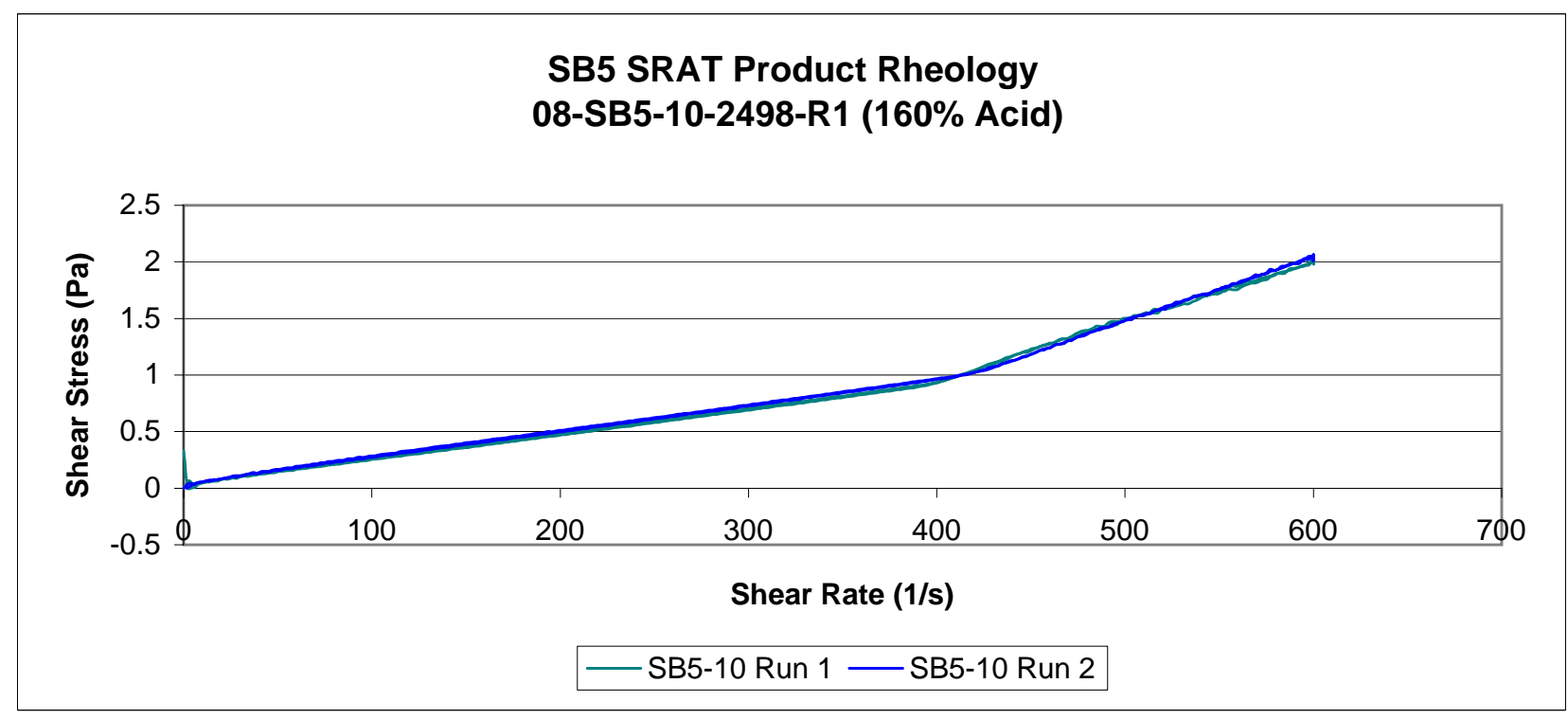

\begin{tabular}{|r|c|c|c|c|}
\hline & \multicolumn{2}{|c|}{ Run 1 } & \multicolumn{2}{c|}{ Run 1 } \\
\hline Curve & Yield Stress, Pa & Consistency, cP & Yield Stress, Pa & Consistency, CP \\
\hline up & 0.04 & 2.21 & 0.06 & 2.26 \\
\hline down & 0.03 & 2.22 & 0.04 & 2.28 \\
\hline
\end{tabular}


Figure D- 5. SB5-7 (115\% Acid) SME Product Flow Curves

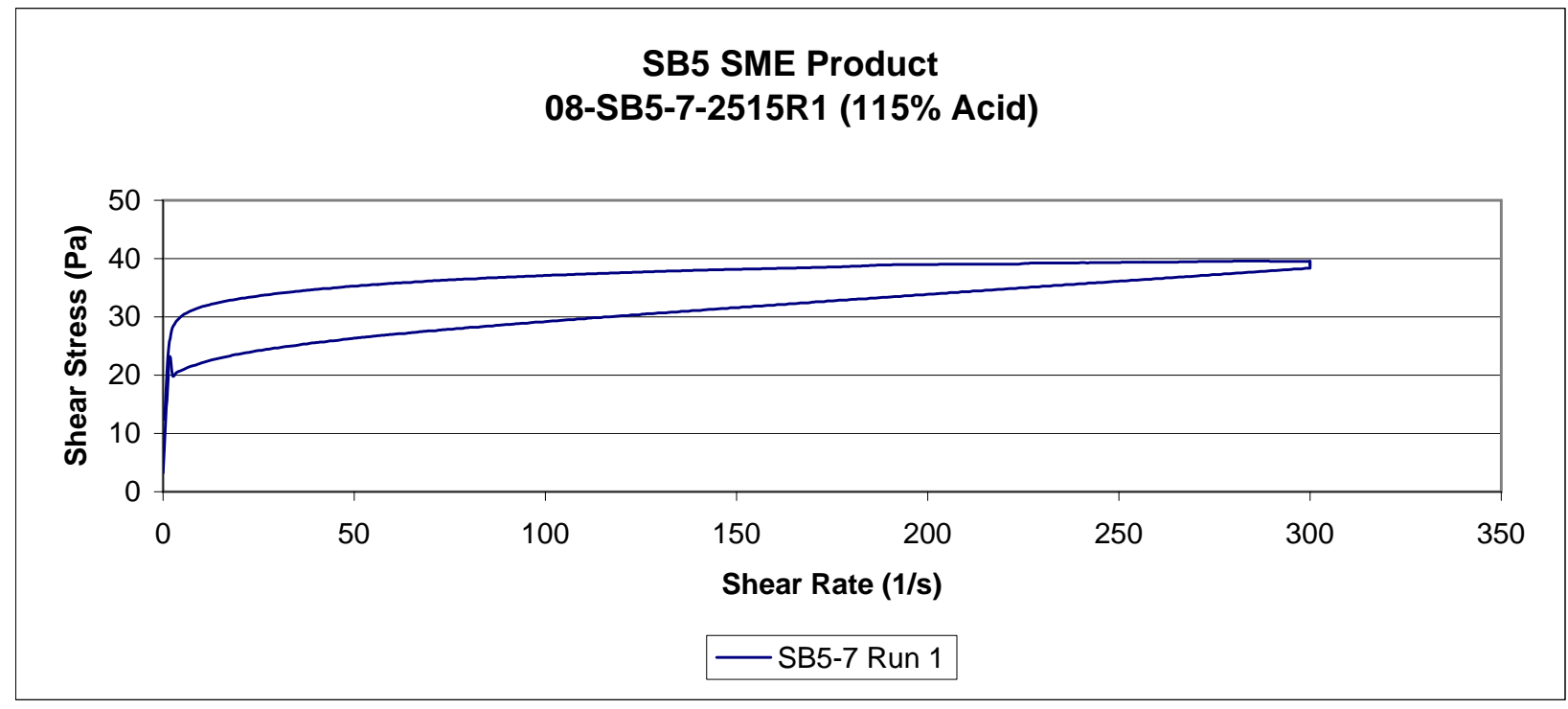

\begin{tabular}{|r|c|c|c|c|}
\hline & \multicolumn{2}{|c|}{ Run 1 } & \multicolumn{2}{c|}{ Run 1 } \\
\hline Curve & Yield Stress, Pa & Consistency, cP & Yield Stress, $\mathrm{Pa}$ & Consistency, CP \\
\hline up & 24.19 & 48.02 & 23.35 & 51.56 \\
\hline down & 35.00 & 17.95 & 37.10 & 17.69 \\
\hline
\end{tabular}

Figure D- 6. SB5-8 (130\% Acid) SME Product Flow Curves

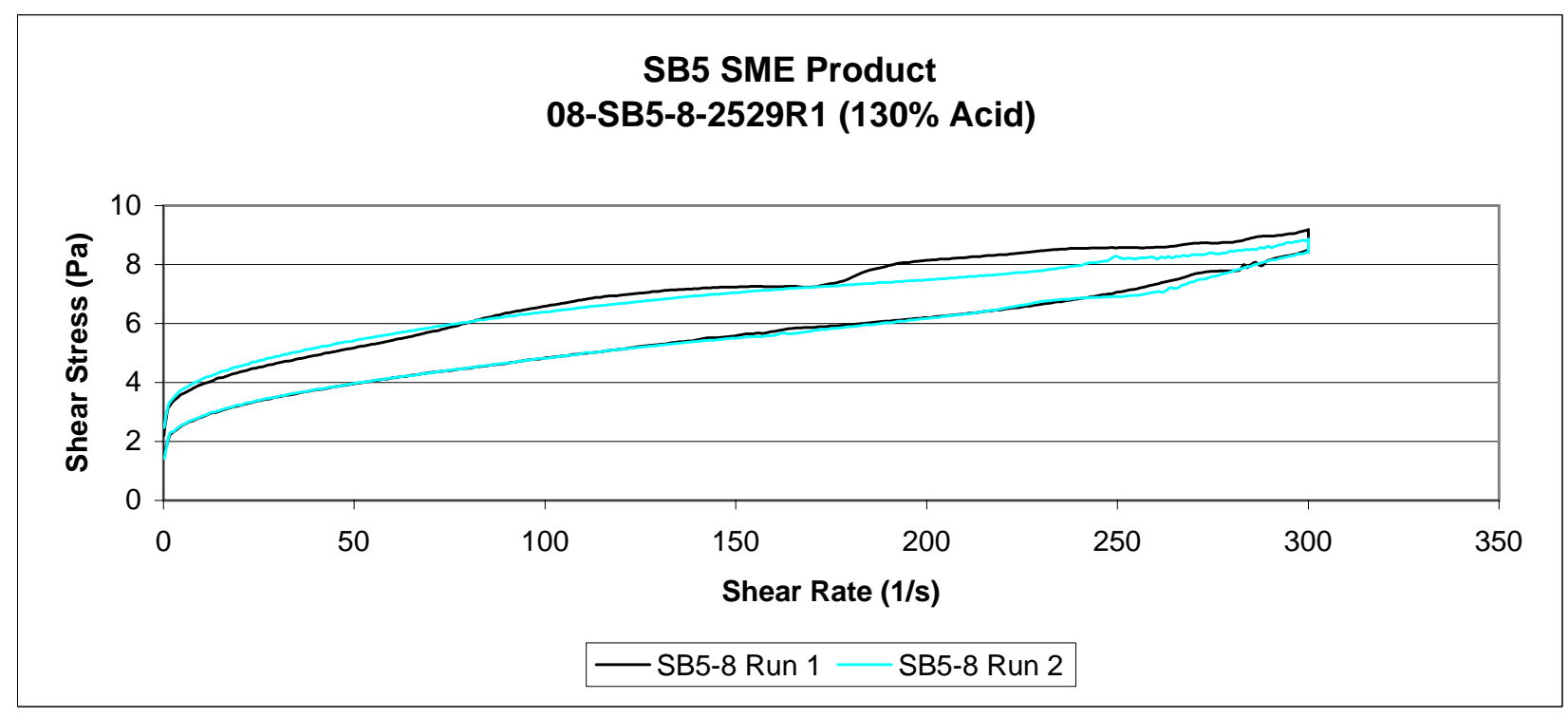

\begin{tabular}{|r|c|c|c|c|}
\hline & \multicolumn{2}{|c|}{ Run 1 } & \multicolumn{2}{c|}{ Run 1 } \\
\hline Curve & Yield Stress, $\mathrm{Pa}$ & Consistency, cP & Yield Stress, $\mathrm{Pa}$ & Consistency, CP \\
\hline up & 3.12 & 16.26 & 3.15 & 15.83 \\
\hline down & 4.78 & 15.45 & 4.98 & 12.72 \\
\hline
\end{tabular}


Figure D- 7. SB5-9 (145\% Acid) SME Product Flow Curves

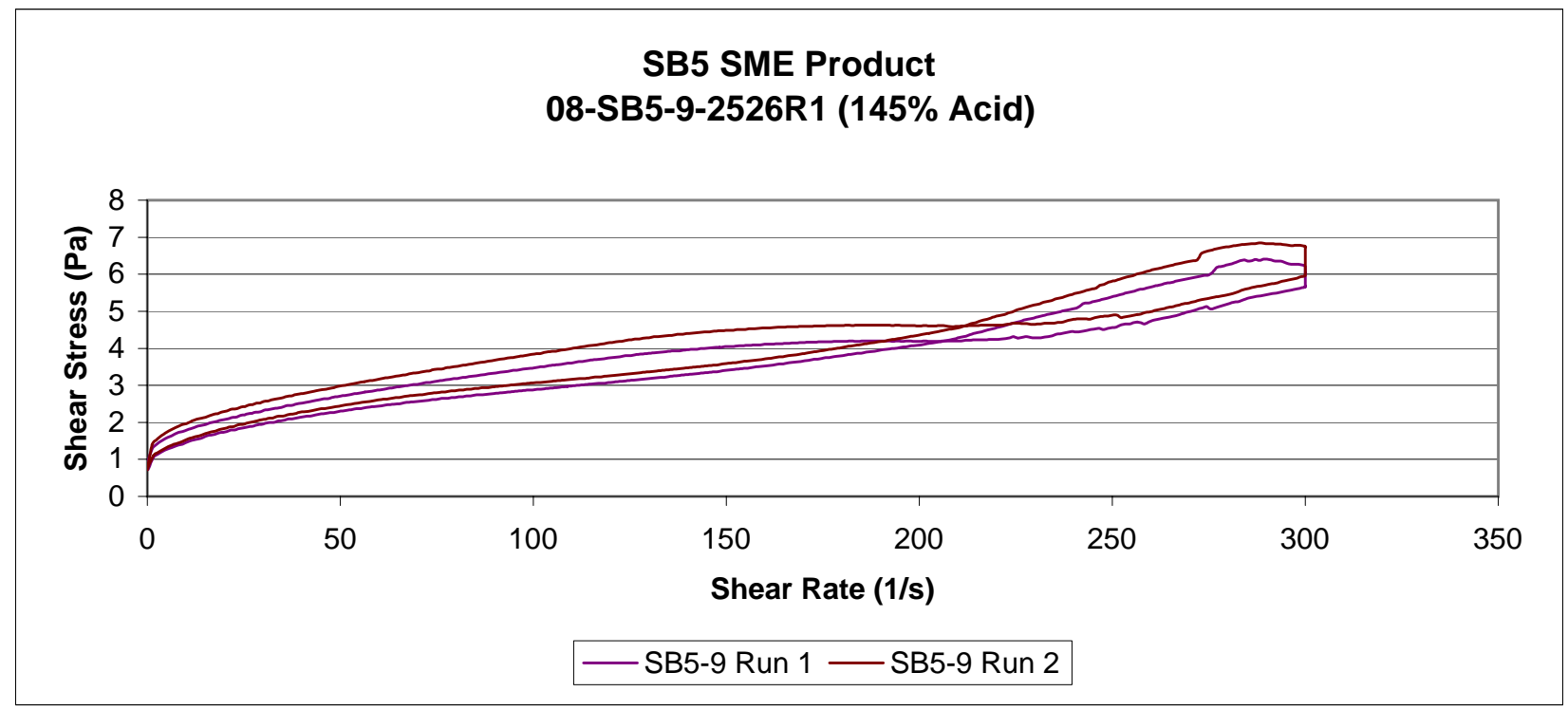

\begin{tabular}{|r|c|c|c|c|}
\hline & \multicolumn{2}{|c|}{ Run 1 } & \multicolumn{2}{c|}{ Run 1 } \\
\hline Curve & Yield Stress, Pa & Consistency, cP & Yield Stress, $\mathrm{Pa}$ & Consistency, CP \\
\hline up & 1.74 & 11.26 & 1.86 & 11.78 \\
\hline down & 1.99 & 14.38 & 2.18 & 16.14 \\
\hline
\end{tabular}

Figure D- 8. SB5-10 (160\% Acid) SME Product Flow Curves

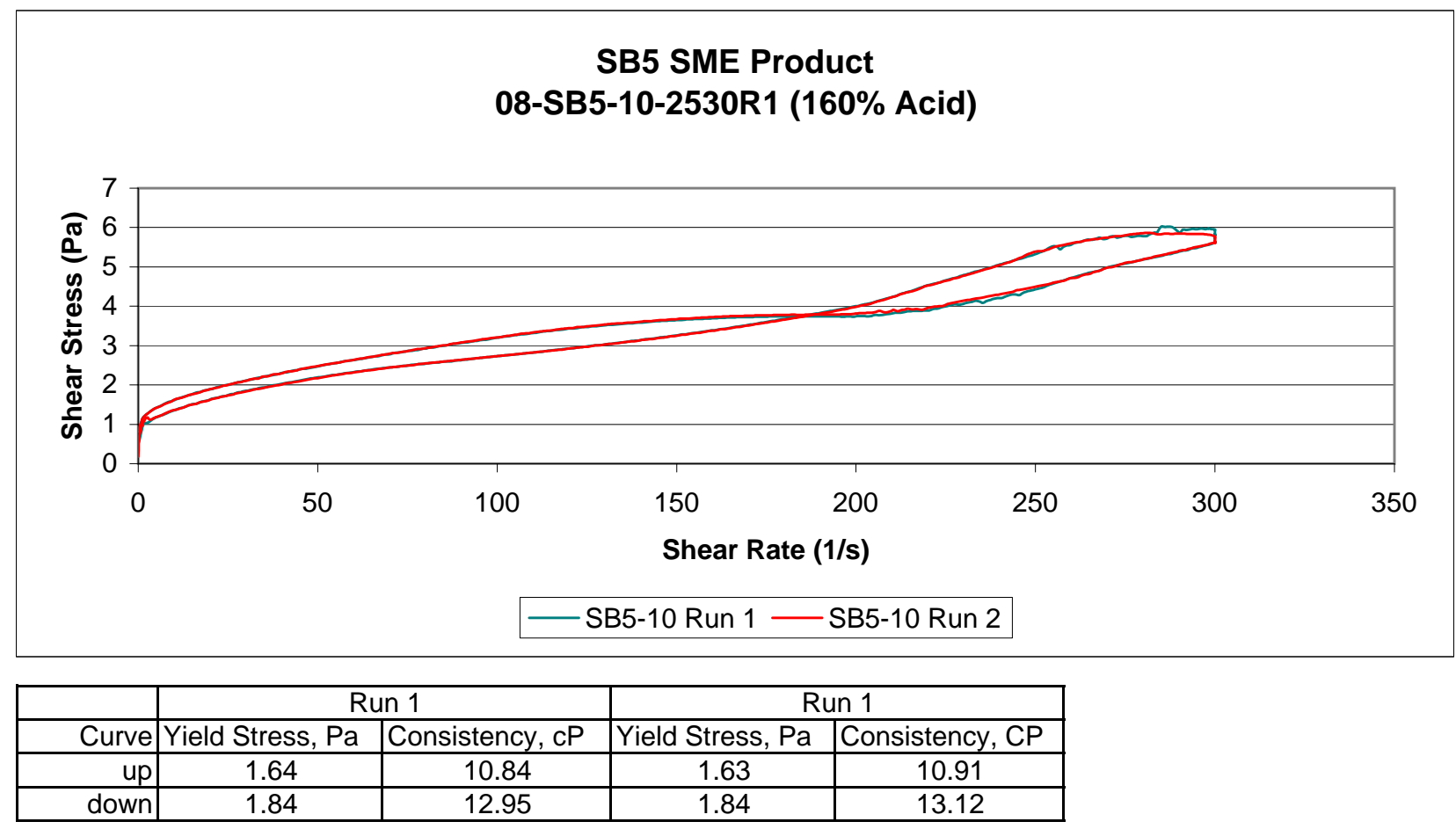




\section{Distribution:}

J.E. Marra, 773-A

J.C. Griffin, 773-A

C.C. Herman, 999-W

A.B. Barnes. 999-W

B. J. Giddings, 786-5A

S.D. Fink, 773-A

C. W. Gardner, 773-A

D. J. McCabe, 773-42A

D.A. Crowley, 773-43A

N.E. Bibler, 773-A

C.M. Jantzen, 773-A

M.E. Stone, 999-W

S.H. Reboul, 773-42A

J.D. Newell, 999-W

C.J. Bannochie, 773-42A

D.C. Koopman, 999-W

D.P Lambert, 999-W

J.M. Pareizs, 773-A

B.R. Pickenheim, 999-W

D.K. Peeler, 999-W

J.E. Occhipinti, 704-S

D.C. Sherburne, 704-S

R.T. McNew, 704-27S

T.L. Fellinger, 704-27S

J.M. Bricker, 704-27S

M.T. Keefer, 766-H

J.F. Iaukea, 704-30S

J.W. Ray, 704-S

B.A. Davis, 704-27S

H.B. Shah, 766-H

J.M. Gillam, 766-H

E.W. Holtzscheiter, 704-15S 